\title{
Hydrology of Volcanic-Rock Terranes
}

GE OL OGICAL S URVEY PROFESSIONAL PAPER 383

This volume was published as separate chapters $A-C$

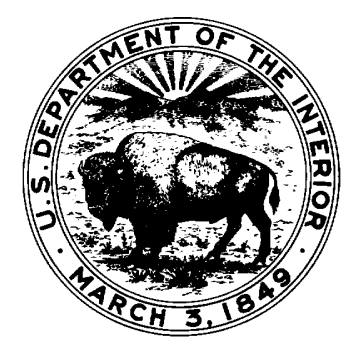


UNITED STATES DEPARTMENT OF THE INTERIOR

ROGERS C. B. MORTON, Secretary

GEOLOGICAL SURVEY

V. E. McKelvey, Director 


\section{CONTENTS}

[Letters designate the separately published chapters]

(A) Storage of ground water behind subsurface dams in the Columbia River Basalt, Washington, Oregon, and Idaho, by R. C. Newcomb.

(B) Geologic factors that control the occurrence and availability of ground water in the Fort Rock Basin, Lake County, Oregon, by E. R. Hampton.

(C) Effect of tectonic structure on the occurrence of ground water in the basalt of the Columbia River Group of The Dalles area, Oregon and Washington, by R. C. Newcomb. 



\section{Storage of Ground Water}

Behind Subsurface Dams in

the Columbia River Basalt

Washington, Oregon, and

Idaho

By R. C. NEWCOMB

HYDROLOGY OF VOLCANIC-ROCK TERRANES

GEOLOGICAL SURVEY PROFESIONAL PAPER 383-A

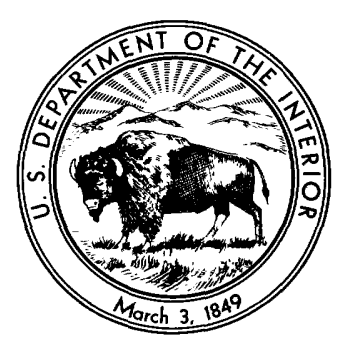




\section{UNITED STATES DEPARTMENT OF THE INTERIOR \\ STEWART L. UDALL, Secretary \\ GEOLOGICAL SURVEY \\ Thomas B. Nolan, Director}

For sale by the Superintendent of Documents, U.S. Government Printing Office Washington 25, D.C. 


\section{O N T E N T S}

Abstract

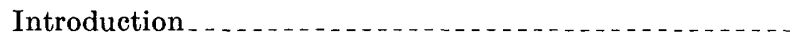

Environment of the barrier reservoirs of ground water.-.

Occurrence of ground water in the basalt. . . ......

Tectonic deformation of the basalt ...........

Tilting and warping

Fault-barrier conditions

Reservoirs behind structural barriers ............ Structural conditions creating barrier reservoirs. Known and tested structural reservoirs . . . . . . . Undeveloped structural reservoirs

Sites proposed for testing for impounded ground

water
Page

A-1

1

1

2

3

3

3

5

5

6

6

8

Plan for test development of barrier reservoirs of ground

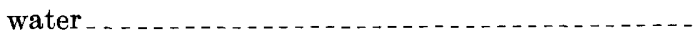

Test-well location

Suggestions as to general specifications for test wells

Test operation of the wells......................

Estimated cost of a proposed test installation and test procedure

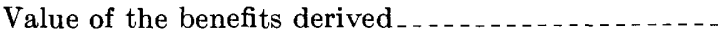

References cited.

Page

A-8

8

10

12

13

15

15

\section{ILLUSTRATIONS}

Figure 1. Map showing the main area underlain by the Columbia River basalt.

Page

A-2

2. View northwest down the valley of the South Fork of the Walla Walla River

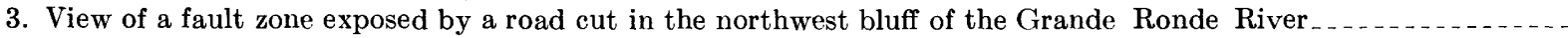

4. Close view of figure 3, showing shearing common to fault zones in the basalt

5. Block diagrams of idealized fault barriers

6. Map of area adjacent to The Dalles, Oreg., showing fault barriers

7. Geologic map of the upper part of the Walla Walla River basin

8. Geologic map of the Grande Ronde River valley above La Grande

9. Block diagram of an idealized fault-barrier reservoir

10. Schematic diagram of some possible arrangements of casings and wells to tap water stored in a barrier reservoir ...

11. Graphs of the average monthly discharge in two rivers where structural reservoirs of ground water are believed present.

12. Cross section of a hypothetical ground-water withdrawal system utilizing an aquifer of a barrier reservoir $\ldots \ldots \ldots$ 



\title{
HYDROLOGY OF VOLCANIC-ROCK TERRANES
}

\section{STORAGE OF GROUND WATER BEHIND SUBSURFACE DAMS IN THE COLUMBIA RIVER BASALT, WASHINGTON, OREGON, AND IDAHO}

\author{
By R. C. Newcomb
}

\begin{abstract}
The Columbia River basalt, a thick sequence of accordantly layered lava flows, forms the bedrock beneath about 50,000 square miles in Washington, Oregon, and Idaho.

The rubbly rock at the top and bottom of some of the flows is permeable and transmits water laterally between the flows. Where the strata are displaced vertically by faults, barriers to movement of the water are common. Where these barriers are transverse to the dip of the basalt layers, ground-water reservoirs are formed. Many such reservoirs are present in mountainous areas or on the flanks of mountain uplands, and their water has been little used to date.

Properly designed and constructed test wells are suggested as a means of determining the feasibility of withdrawing water from these reservoirs during the growing season and allowing the reservoirs to refill during the winter and spring. Benefits from such a practice may be especially great in stream valleys where water is needed in the late summer.
\end{abstract}

\section{INTRODUCTION}

Data gathered in studies of ground water in the Columbia River basalt have made it increasingly clear that, in places, the basalt contains replenishable bodies of water in virtually "dead" storage. Structural barriers, which impede the movement of ground water, are the cause of one type of ground-water reservoir. Some of these reservoirs are in upland or mountainous areas, where the stored water would be available for use during the months of low streamflow each year. Though the amount of water that might be withdrawn annually from any one reservoir may be a modest few hundreds or thousands of acre-feet, the total may be a very important addition to water resources in areas where water is greatly needed.

The existence of these upland reservoirs has been noted in previous reports. This paper is intended to indicate more explicitly their mode of occurrence and to outline a possible method of making tests to determine what part of the water might be replen- ishable. The paper is intended also to estimate the costs of testing and to point out some of the benefits to be derived from the development of this stored water.

Because the proposed test wells would be of the same type as the operational producing wells tapping these reservoirs, they should be constructed as though they were to be merely the first of the permanent producing wells; many features of the foreseen operational-well installations have been incorporated in this method for testing the reservoirs.

The water to be withdrawn from such a reservoir is referred to as "new" water because it would otherwise be unavailable. Under the assumptions of this plan, the water taken from storage as new water during the months of greatest need would be replaced during the winter and spring when runoff is in excess of needs.

The presence of these reservoirs has been noted in several reports on local areas, and there have been many inquiries for additional information and for suggestions on suitable methods of development. This plan for testing and the suggested procedure for any subsequent development of these reservoirs carry no implications as to who might undertake that work. If the first tests show development to be feasible, many organizations may be interested in the use of such reservoirs.

The paper was prepared under the Federal project for study of the hydrology of the Coluribia River basalt. Much of the supporting information is contained in reports on areas studied in cooperation with the State Engineer of Oregon, the Department of Conservation of Washington, and other local agencies.

\section{ENVIRONMENT OF THE BARRIER RESER- VOIRS OF GROUND WATER}

The Columbia River basalt is a thick sequence of accordantly layered lava flows of basaltic and basic andesitic composition. The main part underlies most 


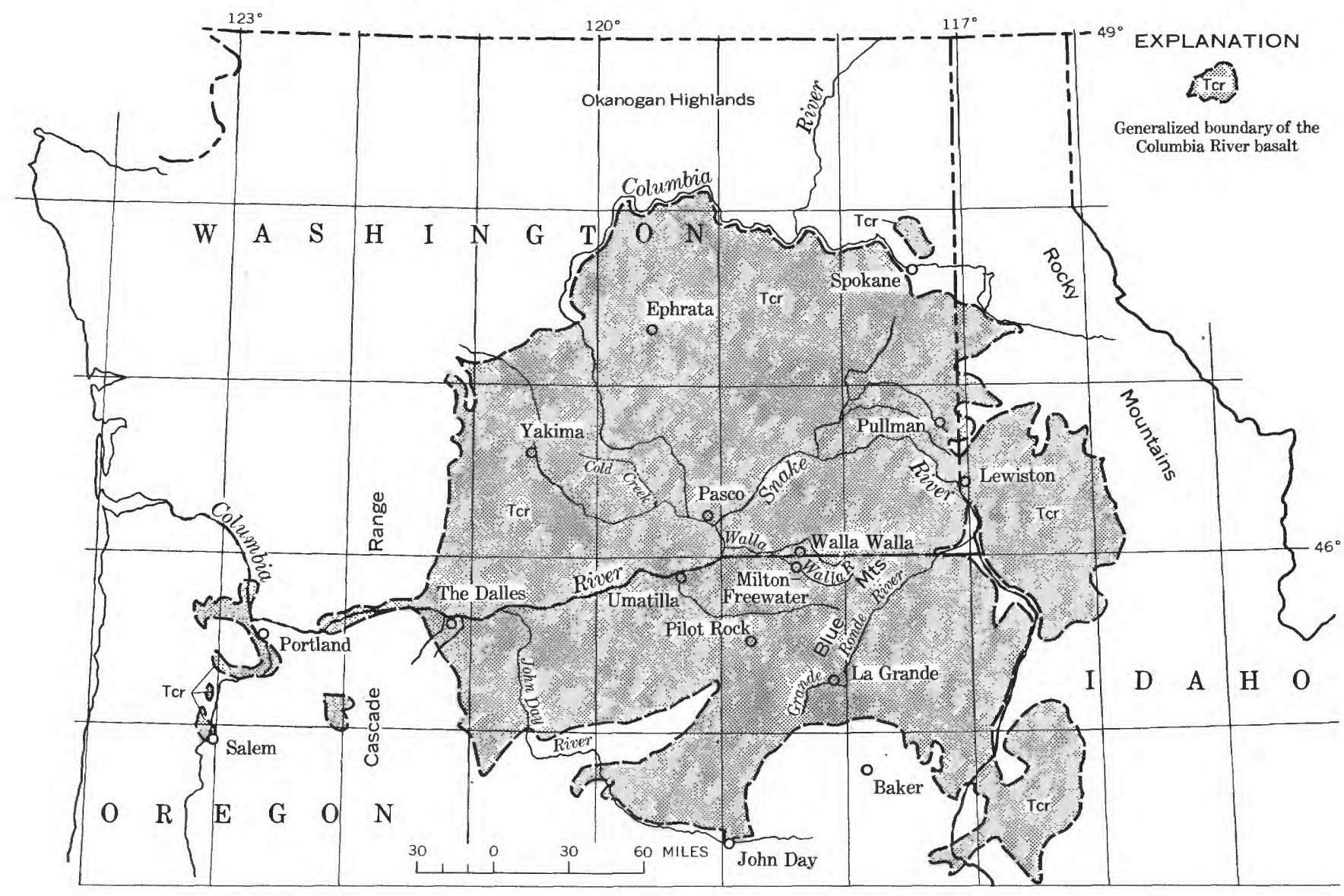

Frgure 1.-Map showing the main area underlain by the Columbia River basalt, Washington, Oregon, and Idaho.

of the area that extends westward from the northern Rocky Mountains to the northern Cascade Range, and southward from the Okanogan Highlands to the mountains of central Oregon (fig. 1). In the central part of this area the basalt is known to be more than 5,000 feet thick in places, and it tapers to zero on the older rocks at its margins. The individual lava flows range in thickness from 5 to 150 feet and average about 50 feet. The average flow consists of dense, almost flintlike, partly fractured rock at its base; grades vertically to dense, massive columnar-jointed rock at its center; and then to vesicular-and in some places rubbly-rock at its top. Systems of fractures cut the rock into irregular columnar, cubical, and platy blocks that range from 2 to 60 inches across; the fractures formed when the lava was cooling.

\section{OCCURRENCE OF GROUND WATER IN THE BASALT}

Ground water moves through the rock largely in the permeable zones at the top of some flows. These tabular zones commonly are about 3 to 10 feet thick. In places where 2 of these permeable interflow zones are separated by highly jointed lava, the total thick- ness of a single water-bearing stratum may be 25 feet or more.

The massive centers of some flows are relatively impermeable, and in places thick zones of the rock consist of several successive flows which are tight and nonwater bearing. Above the water table, these impermeable zones cause water to be perched, and below that level, in places, they cause the water-bearing zones to have no hydraulic continuity and, therefore, to have different water-pressure levels. Also, where the basalt is tilted or where the water movement is impeded by barriers, the water below these impermeable zones may be confined under pressure.

Exact data are lacking not only on the percentage of interflow zones that are permeable and on their average water-yielding capacities, but also on their average thickness and permeability. These factors have been partly evaluated in a computation of the yield of water to an average well. A computation made by the writer in 1947 , based on records of several hundred wells that penetrated 300 feet or more of the basalt, shows that 1 gallon of water per minute for each foot of well that is below the regional water 
table is the approximate average yield obtained by a 10- or 12-inch well when pumped at the common drawdown of 50 to 100 feet (Newcomb, 1959). Subsequent records show that this estimated average is conservative for the yields obtained from the better designed wells now being constructed.

Data indicate that the average capacity of the basalt to transmit ground water is generally uniform to a depth of about 1,500 feet, where the basalt is that thick. Not enough wells have been drilled deeper than 1,500 feet to warrant making estimates of the average permeability of the basalt below that depth.

\section{TECTONIC DEFORMATION OF THE BASALT}

\section{TILTING AND WARPING}

The basalt was extruded, in Miocene and Pliocene(?) time, as nearly horizontal flows. Subsequently, it was warped during at least two periods of folding. In most places, the basalt is now tilted in broad warps of the earth's crust. The general pattern of the regional tilting includes gentle dips inward from the older rocks near the boundary mountain ranges, a series of anticlines and intervening synclines that extend through central Washington eastward from the Cascade Range, and a broad anticline-known as the Blue Mountain anticline - that curves northeastward from the mountains of central Oregon. There are also many local structures. (See fig. 2.)

Because ground water, which has percolated into the basalt, finds the easiest path of travel in the permeable interflow zones, it moves generally down the dip of inclined strata. Thus, in general, the anticlines cause water to transfer laterally into the downwarped synclines, which are gathering places for the ground water in the basalt. Consequently the water table, or the piezometric surface of the ground water, beneath areas of inclined basalt commonly lies at or near the level of the principal streams. In synclines the water table may lie at or near the drainage level, or the ground water may be confined under artesian pressure.

Most of the highly productive wells in the basalt are in downwarps such as occur at Walla Walla, Cold Creek, and Ephrata, Wash.; The Dalles, Umatilla, and Pilot Rock, Oreg.; and Lewiston, Idaho.

\section{FAULT-BARRIER CONDITIONS}

During the deformation of the basalt, bending did not relieve all the stress in the rock at some places. Locally, these unrelieved forces produced fractures, called faults, along which the rocks on opposite sides were displaced. These faults range from large shear fractures along which the rocks on opposite sides were displaced several thousand feet, to small ones where

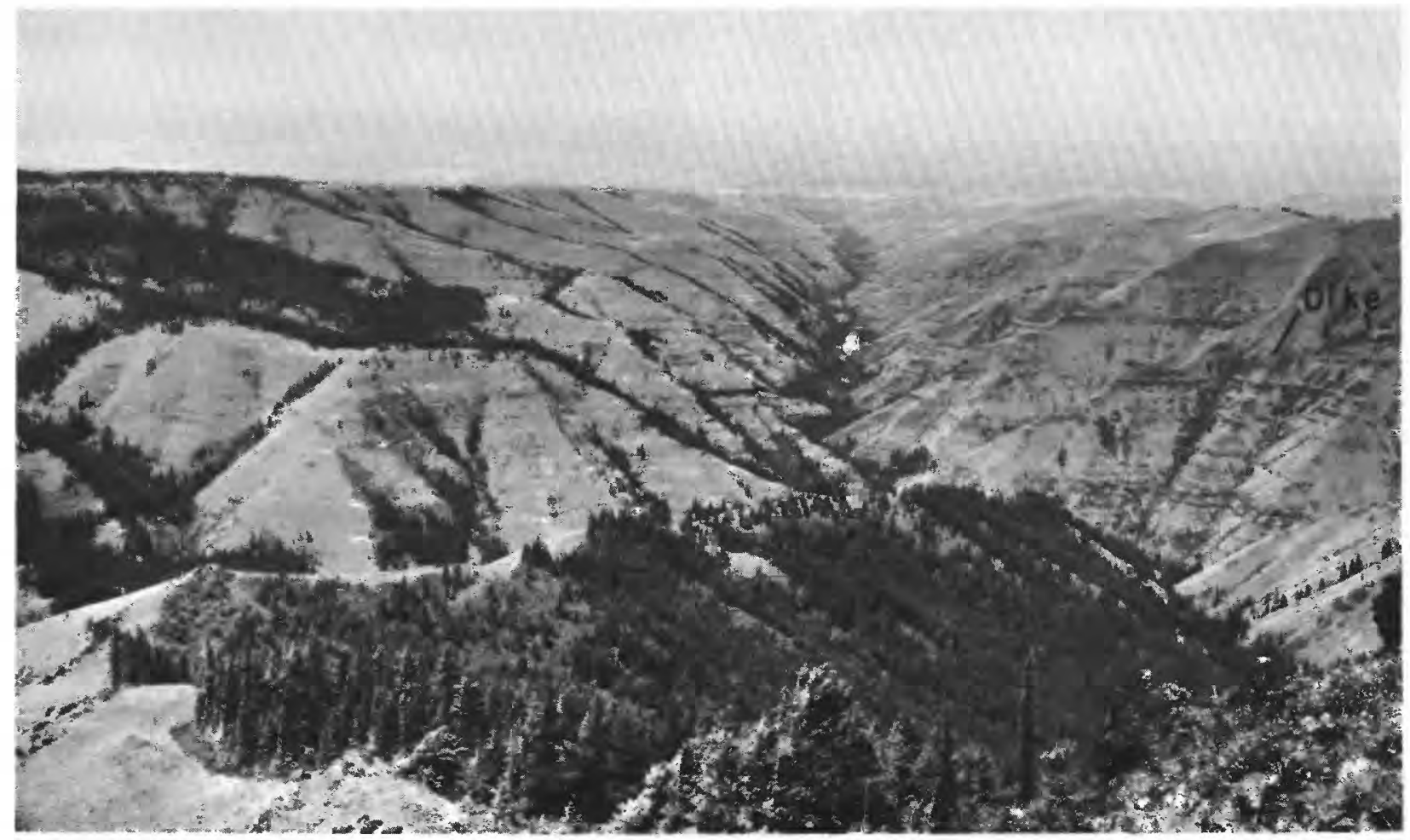

Figure 2.-View northwest from the Blue Mountain upland near McIntyre Lookout, Oreg., down the valley of the South Fork of the Walla Walla River, where the downstream dip of the basalt is apparent. 


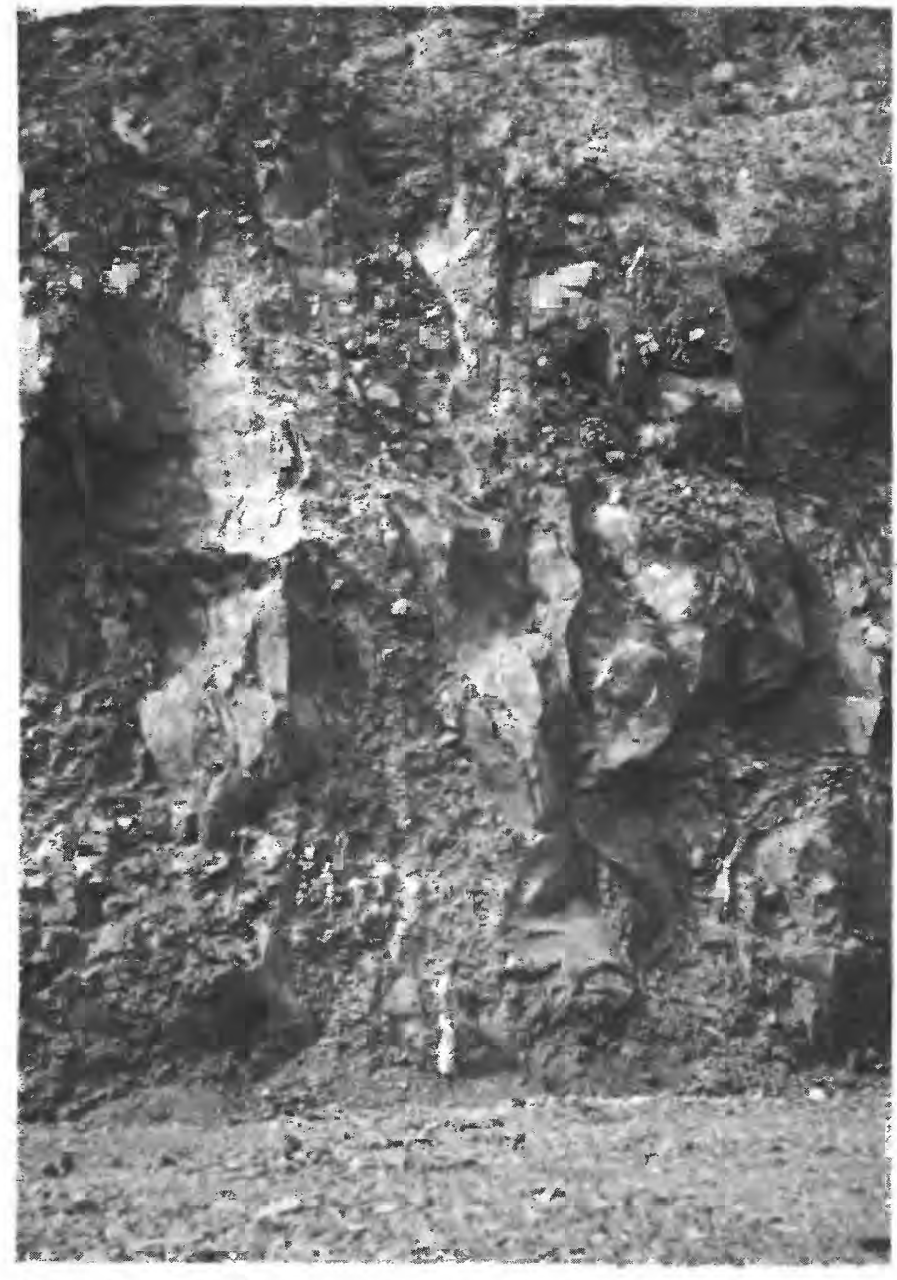

Frgure 3.-View of a fault zone exposed by a road cut in the northwest bluff of the Grande Ronde River above La Grande, Oreg., in sec. 31, T. 2 S., R. 37 E.

little displacement occurred. Rather than a single plane of fracture, the larger faults consist of zones of shattered and broken rock several tens or hundreds of feet wide (fig. 3). Even some of the small faults, along which the displacement is measured in tens of feet, are zones of sheared and shattered rock.

Nearly all the faults are of the type commonly called normal faults, in which the fracture plane dips toward the downthrown side. This type generally is considered to indicate that tensional strains were responsible for the faulting. The most common inclination, or dip, of the fracture planes is between $60^{\circ}$ and $70^{\circ}$ below the horizontal.

The water-transmission characteristics of the fault zones differ considerably from those of the unbroken basalt. The fault fracturing provides a zone of low permeability (fig. 3), along which small amounts of water can move vertically in some places. The lowest sags in the fault traces, where they cross stream valleys,

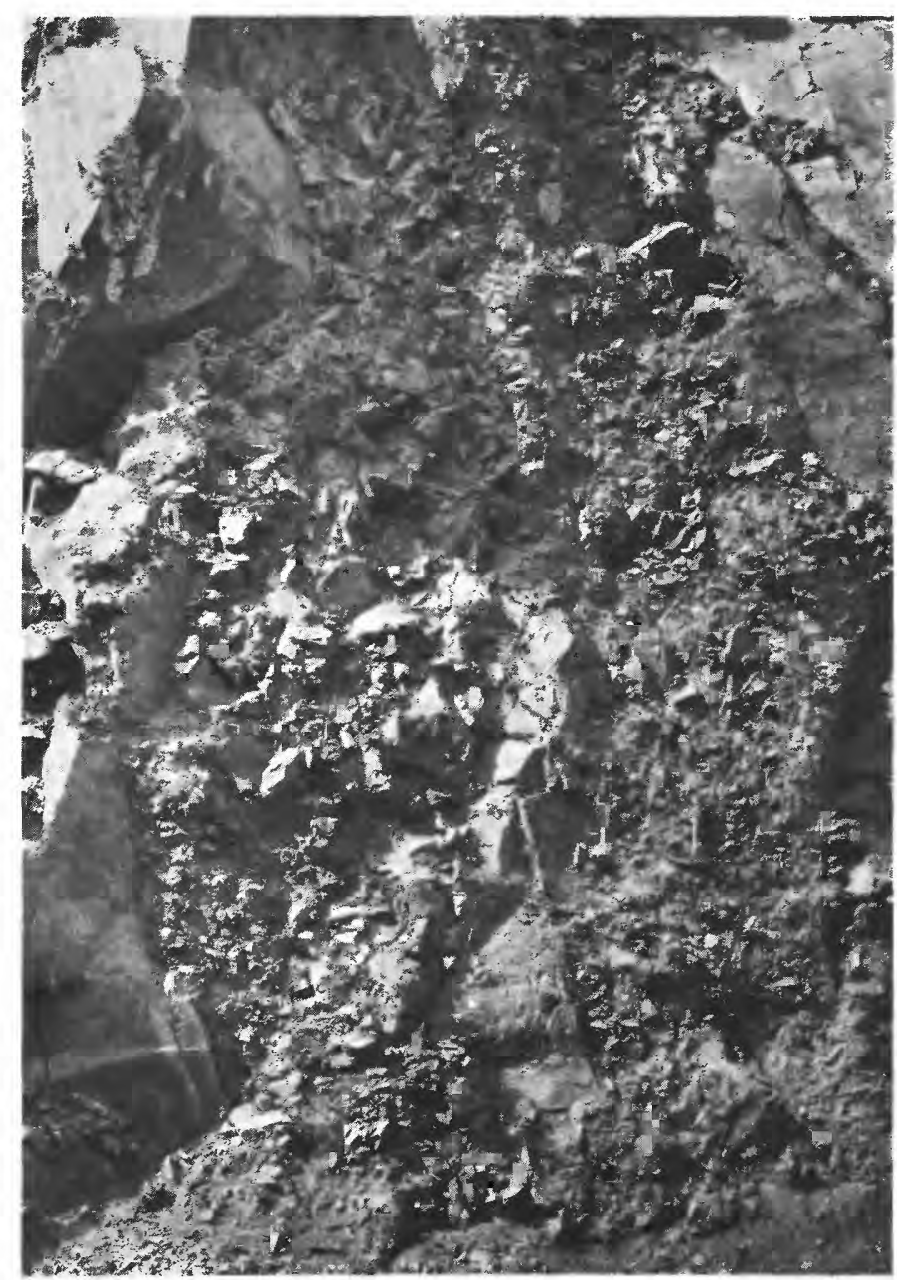

Figure 4.-Close view of part of figure 3 showing the shearing common to fault zones in the basalt. (Pick, at lower right of the center, is 14 inches long.)

are generally marked by small seepage springs. The permeable interflow zones that provide the lateral, or generally horizontal, routes of ground-water movement are obliterated in the fault zones and the lateral movement of the water is virtually stopped. Thus, a fault zone constitutes a barrier to the otherwise normal lateral movement of ground water.

In addition to those created by faulting, barriers can occur also along the axis of sharp folds owing to disruption of the permeable zones by the interflow grinding as the rock stretched over sharp bends of the basalt. These two types of localized destruction of the tabular paths of lateral movement of water in the basalt are grouped together under the term "structural barriers" (Newcomb, 1959). Intrusive dikes can also form barriers. However, dikes are not so numerous or so continuous as the structural barriers, and in many places they are not arranged transverse to the direction of ground-water movement. 
RESERVOIRS BEHIND STRUCTURAL BARRIERS

STRUCTURAL CONDITIONS CREATING BARRIER RESERVOIRS

If a fault zone is parallel to the direction of groundwater movement, it has little effect on the lateral movement of the water. However, if the fault zone is transverse to the direction of movement, the percola- tion down the gradient may be blocked and the water deflected around it; or, if the fault is extensive, the water may be dammed and may reach the surface above the barrier (fig. $5 \mathrm{~A}$ ). Thus, if a fault zone crosses the axis of a syncline, an almost complete barrier may be formed (fig. $5 B$ ). Surface outlets (and inlets) commonly occur at the points where the individual water-

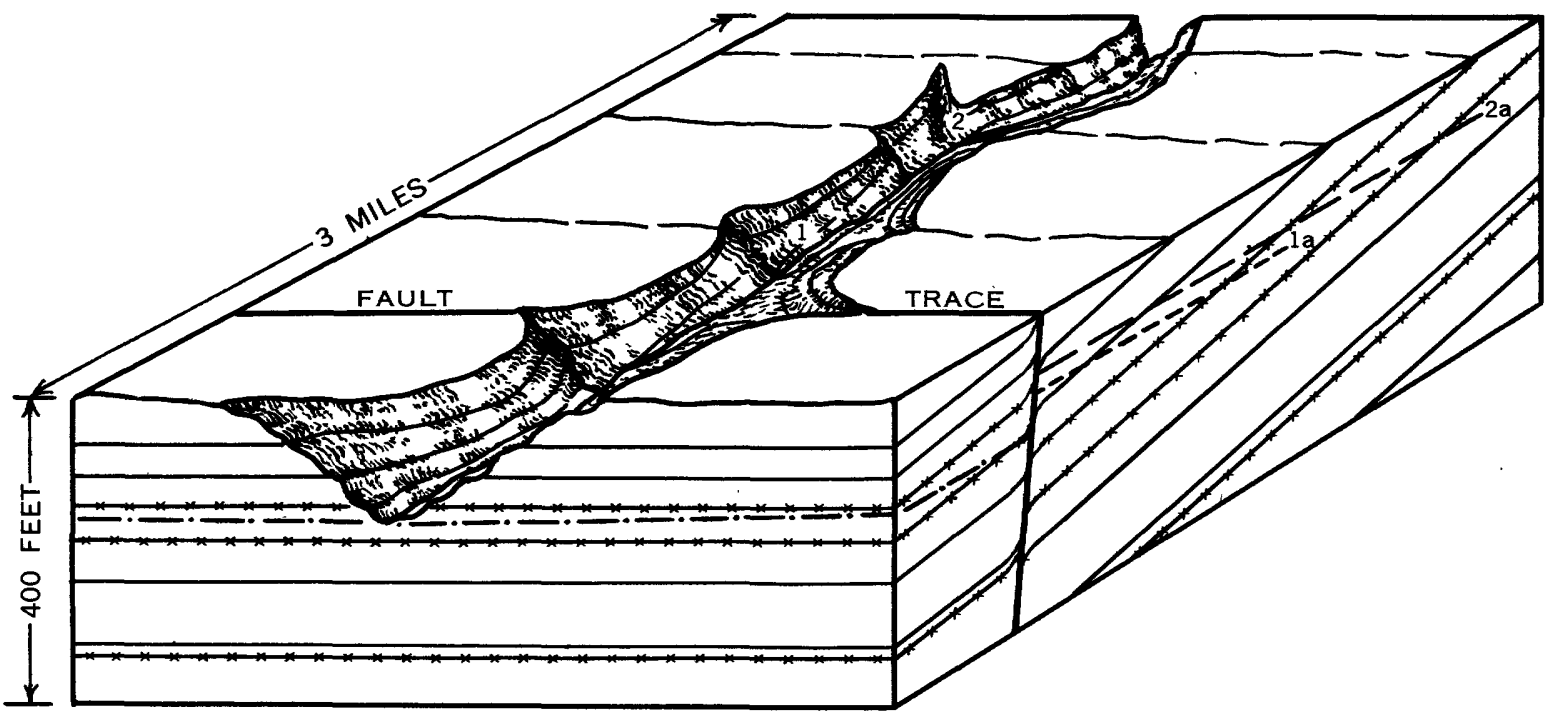

A. A monoclinal dip of the basalt cut

by a transverse fault barrier

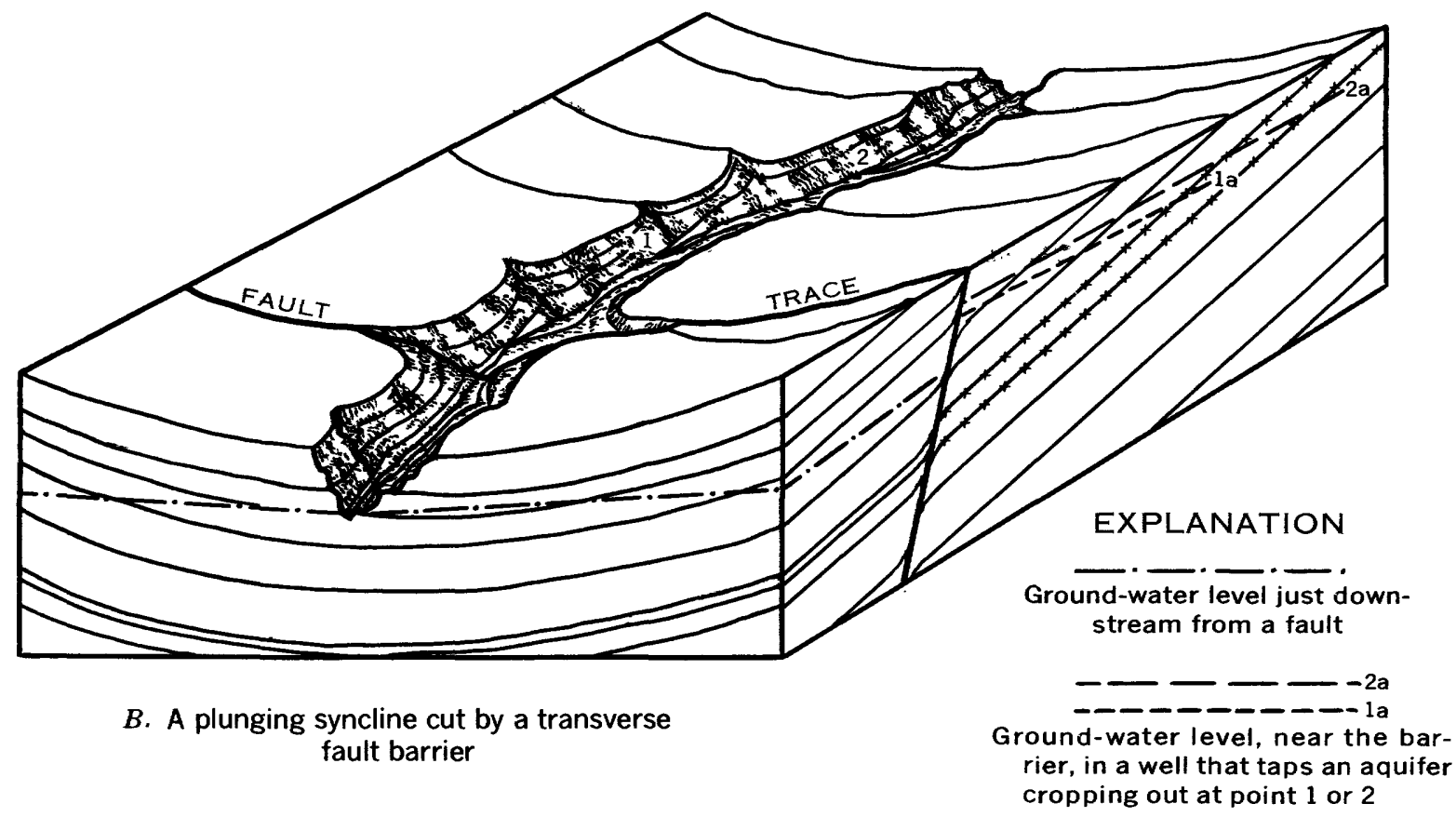

Water-bearing layer shown on the sides of the diagrams

FigURE 5.--Structural features creating barrier reservoirs, 
bearing zones crop out in streambeds above the barrier. The outlets of some reservoirs may occur also at other points in the streambeds upstream from the fault zone, because of upward cross-strata leakage from the aquifer.

\section{KNOWN AND TESTED STRUCTURAL RESERVOIRS}

In the quest for water in the Columbia River basalt, several ground-water reservoirs of the type described have been tapped by wells. Some reservoirs have been rather thoroughly developed and their extent and mode of occurrence are well defined. Others have been less well developed, and some have been tapped by only a few wells or by a single well.

Possibly the most thoroughly developed groundwater reservoir of this type is that impounded behind the fault or sharp fold which passes through the basalt bedrock north of College Place, Wash., in the Walla Walla syncline. The fault or sharp fold is marked by a 200 -foot-high ridge in the bedrock surface beneath the 500 feet of sedimentary deposits which underlie the valley floor. The ridge trends east-northeast across the broad slope of part of the south limb of the Walla Walla syncline. It marks a vertical barrier to the lateral movement of ground water. When the first wells were drilled, during the years 1900-10, the artesian head of the water in the deep wells tapping the uppermost 200 feet of the basalt on the upgradient side of this barrier was about 140 feet above the land surface and 200 feet above the level of the water table in the nearby wells tapping the same rocks on the downgradient side of the barrier (Newcomb, 1951).

Another developed reservoir upgradient from a fault (or sharp fold) occurs in the Upper Cold Creek syncline east of Yakima, Wash. The main part of the reservoir area lies in secs. $25,26,27,34,35$, and $36, \mathrm{~T}$. 13 N., R. 24 E., and secs. 30 and 31, T. 13 N., R. 25 E. (Hart, 1958). The lower part of this plunging syncline is mantled by sedimentary deposits, which continue eastward beneath the high terraces in the Hanford Reservation of the U.S. Atomic Energy Commission. The ground-water reservoir of artesian water terminates abruptly in alinement with the sharp east edge of the Yakima Ridges to the north and south of the syncline. The easternmost well, the McGee, is about a quarter of a mile upslope from the inferred location of the barrier. Originally, the pressure level of the ground water at the McGee well was 212 feet above the land surface and about 580 feet above the level of the ground water in the basalt east of the barrier.

An area south and southwest of The Dalles, Oreg., has several partly known ground-water reservoirs behind fault barriers in the basalt (fig. 6). The basalt to the south, east, and west dips into the Dalles syn- cline (Piper, 1932). It is covered in many places by several hundred feet of sedimentary beds called the Dalles formation. Numerous faults are known to trend northwestward across the northeastward-plunging syncline; other faults are believed to be present but have not been mapped. A fault or fold escarpment runs south-southeastward through the western part of The Dalles and between the Renken well, 704 feet deep and at an altitude of about 625 feet, in the NW1/4 NE1/4 sec. 22 ; and the Stark well, 536 feet deep and at an altitude of about 700 feet, in the $\mathrm{NW}^{1} / 4 \mathrm{SW}^{1} / 4$ sec. 27 , T. 1 N., R. 13 E. The Stark well, three-quarters of a mile upgradient from this apparent barrier, has a static water level slightly above the land surface. The Renken well, half a mile downgradient from the apparent barrier, has a water level 520 feet below the land surface. The difference of about 600 feet in the water level of these two wells is apparently due to the barrier effects of the intervening fault or sharp fold (fig. 6). Other reservoirs of ground water stored behind structural barriers occur in the Mill Creek and upper Threemile Creek areas near The Dalles.

Ground-water reservoirs that are believed to be due to structural barriers occur in other areas underlain by the basalt, but most of the barriers are too imperfectly known to serve as examples at this time.

Individual wells known to illustrate the effects of barriers in creating ground-water reservoirs of relatively high water-pressure levels are (1) the Marion Cockburn well on Pine Creek, northwest of MiltonFreewater, Oreg., (Newcomb, 1951) ; (2) the Bureau of Reclamation test hole 1 at the Harris Dam site on the South Fork of the Walla Walla River in the NW $1 / 4 \mathrm{SE} 1 / 4$ sec. 12 , T. 4 N., R. 37 E. (G. E. Anderson, written communication); and (3) the flowing well of the city of John Day, Oreg., on the north side of the fault which follows the center of the John Day River valley at that place.

\section{UNDEVELOPED STRUCTURAL RESERVOIRS}

Many untested reservoirs that have been formed by structural barriers should occur in the type conditions present in the mountain areas and on the flanks of uplands. At those places little immediate need exists for additional water for public supply, irrigation, industrial, or other uses, but farther downstream there is urgent need for additional water, especially in the summer and autumn when local supplies are inadequate. Thus, the present utilization of much of this stored ground water may require transporting it in streams, pipelines, or flumes to points of use. Development of these supplies might also be of use in fish culture, power generation, waste disposal, recreation, 
SUBSURFACE DAMS IN COLUMBIA RIVER BASALT

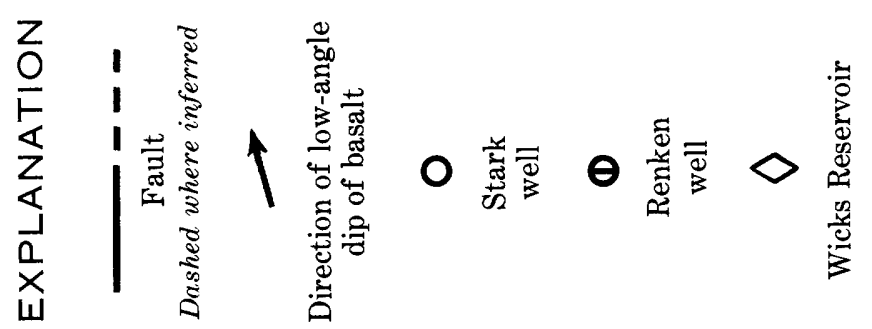

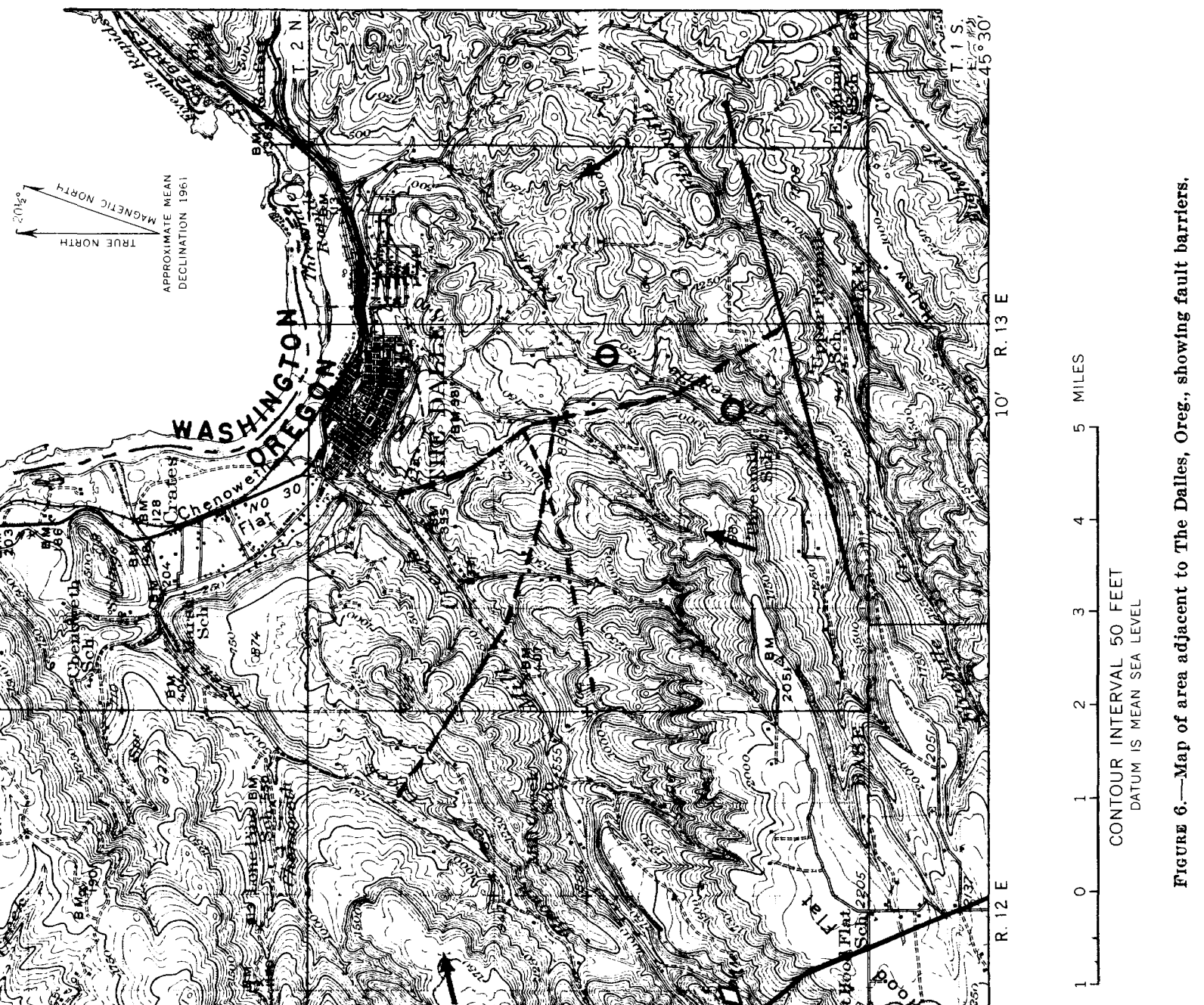


and other activities. The use of the upland reservoirs, as proposed in this paper, is foreseen as a future source of supplemental water to supply some water-short valleys.

\section{SITES PROPOSED FOR TESTING FOR IMPOUNDED GROUND WATER}

Areas (shown on figs. 1, 6, 7, and 8) in which transverse faults are known to cut the basalt, where it dips on a wide front toward a valley or is warped into a syncline, are present in the valleys of the Walla Walla River, Grande Ronde River, Mill Creek near The Dalles, and John Day River. Some of these areas appear to overlie structural conditions nearly ideal for barirer reservoirs in the basalt. There are many other areas where such reservoirs may occur, but the conditions are not now sufficiently known to warrant testing before further geologic investigations are made.

In the Walla Walla River basin the layered basalt dips generally westward from the crest of the Blue Mountain anticline and extends beneath the alluvial fill which underlies the valley plains. The South Fork, North Fork, Mill Creek, and lesser tributaries flow down the regional slope in deep canyons, and the basalt is cut by several faults which trend generally transverse to the dip of the basalt (fig. 7). The basalt is believed to be at least 500 feet thick beneath the channel bed in most of these canyons. On the basis of the conditions observed in areas of similar geologic structure and on the few well data for this area, the fault zones probably impound ground water in the basalt. Sites where drilling is considered desirable to test for reservoirs of ground water are (1) along the South Fork, just south of the center of sec. 7, T. 4 N., R. $38 \mathrm{E}$., upstream from the large fault called the Tom Hite fault; (2) along Mill Creek near the northeast corner of sec. 19, T. 6 N., R. 38 E., upstream from the Kooskooskie fault; and (3) along the South Fork, near the east line of sec. 14, T. 4 N., R. 37 E., upstream from the Elbow Bend fault. These and other likely sites are shown on figure 7.

In the upper part of the Grande Ronde River basin (figs. 1 and 8) the basalt dips southeastward off the Blue Mountain anticline and northwestward from the Elkhorn Ridge to form an elongate synclinal sag, which is followed eastward by the Grande Ronde River from noar Starkey to the valley plain at La Grande (Hampton and Brown, in press). The syncline is cut transversely by northward-trending faults (fig. 8), and some should impound ground water. The following sites considered advisable to test for potential ground- water reservoirs are all upstream from faults: (1) along the Grande Ronde River in the SW1/4 sec. 36, T. 3 S., R. 35 E., (2) in the NE $1 / 4$ sec. 15 , T. 3 S., R. $36 \mathrm{E}$., and (3) in the $\mathrm{SW} 1 / 4 \mathrm{SE} 1 / 4$ sec. 31 , T. $2 \mathrm{~S}$., R. 37 E.

South and west of The Dalles, Oreg., the strata of basalt and the overlying sedimentary rocks of the Dalles formation dip into a plunging syncline that trends northeast through The Dalles (fig. 6). The basalt in this syncline is broken into blocks by faults, many of which are imperfectly known because they are obscure in the softer materials of the overlying sedimentary rocks. Some of the barrier reservoirs in the basalt have been tapped and partly developed by present wells. A well along the South Fork of Mill Creek, near the $\mathrm{N} 1 / 4$ cor. sec. 33 , T. 1 N., R. 12 E., would provide a test of ground-water-reservoir conditions above the strong fault zone that crosses the South Fork near the Wicks Reservoir of The Dalles City Water Department. Other possible barrier reservoirs may be present in that area, but their testing can be deferred until the fault system is known in more detail.

\section{PLAN FOR TEST DEVELOPMENT OF BARRIER RESERVOIRS OF GROUND WATER}

\section{TEST-WELI LOCATION}

The present data for developed barrier reservoirs indicate that it is preferable to drill wells near enough to the fault zones to obtain the maximum hydrostatic pressure, but far enough from them to avoid drilling in the disturbed or shattered rock. The proposed site of each production well should be on the upstream side of the fault zone. The faults of the Walla Walla River basin (fig. 7) and the Mill Creek area (fig. 6) dip steeply downstream; at the Grande Ronde River sites (fig. 8) some faults dip steeply upstream and others dip steeply downstream. In drilling on the upthrown side of a normal fault, the well can be sited reasonably close to the fault (as near as 200 or 300 feet). On the downthrown side of a normal fault, because the fault plane dips toward the well, a greater distance should be allowed-probably at least 300 feet plus a distance equal to the expected depth of the well.

It is proposed that the test wells be located near stream level, so as to gain full advantage of any free artesian flow, and still be adequately sited and equipped with foundations and buttresses to be protected against damage by floodwaters of the stream. Also, the wells will need to be situated to permit the access of mobile drilling equipment. 
SUBSURFACE DAMS IN COLUMBIA RIVER BASALT

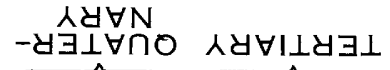
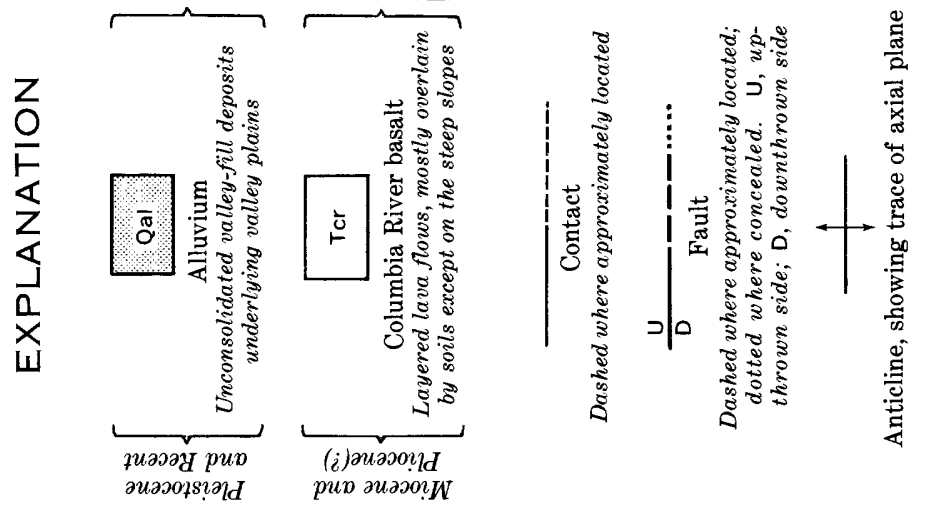

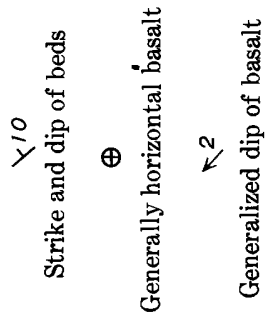



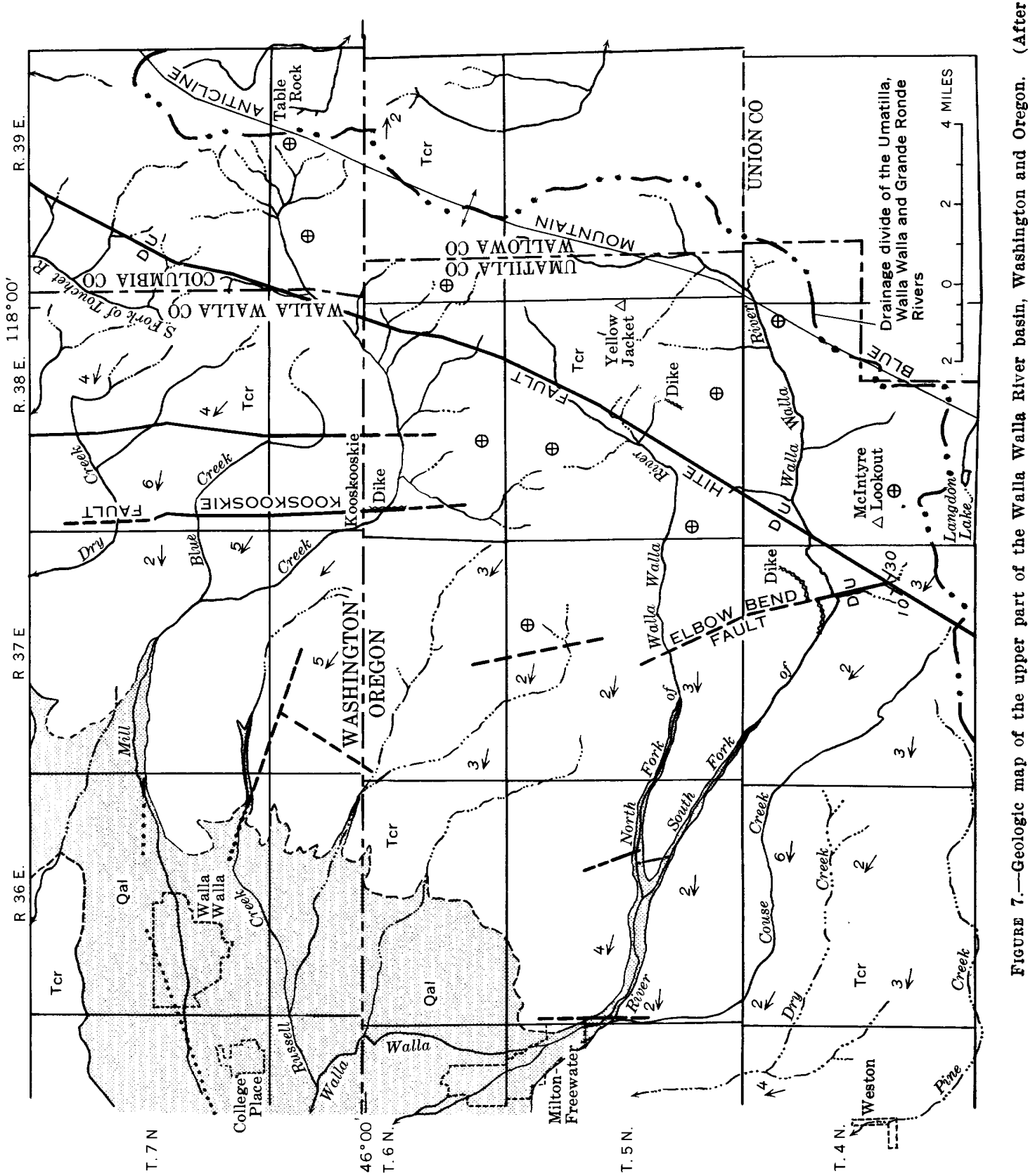




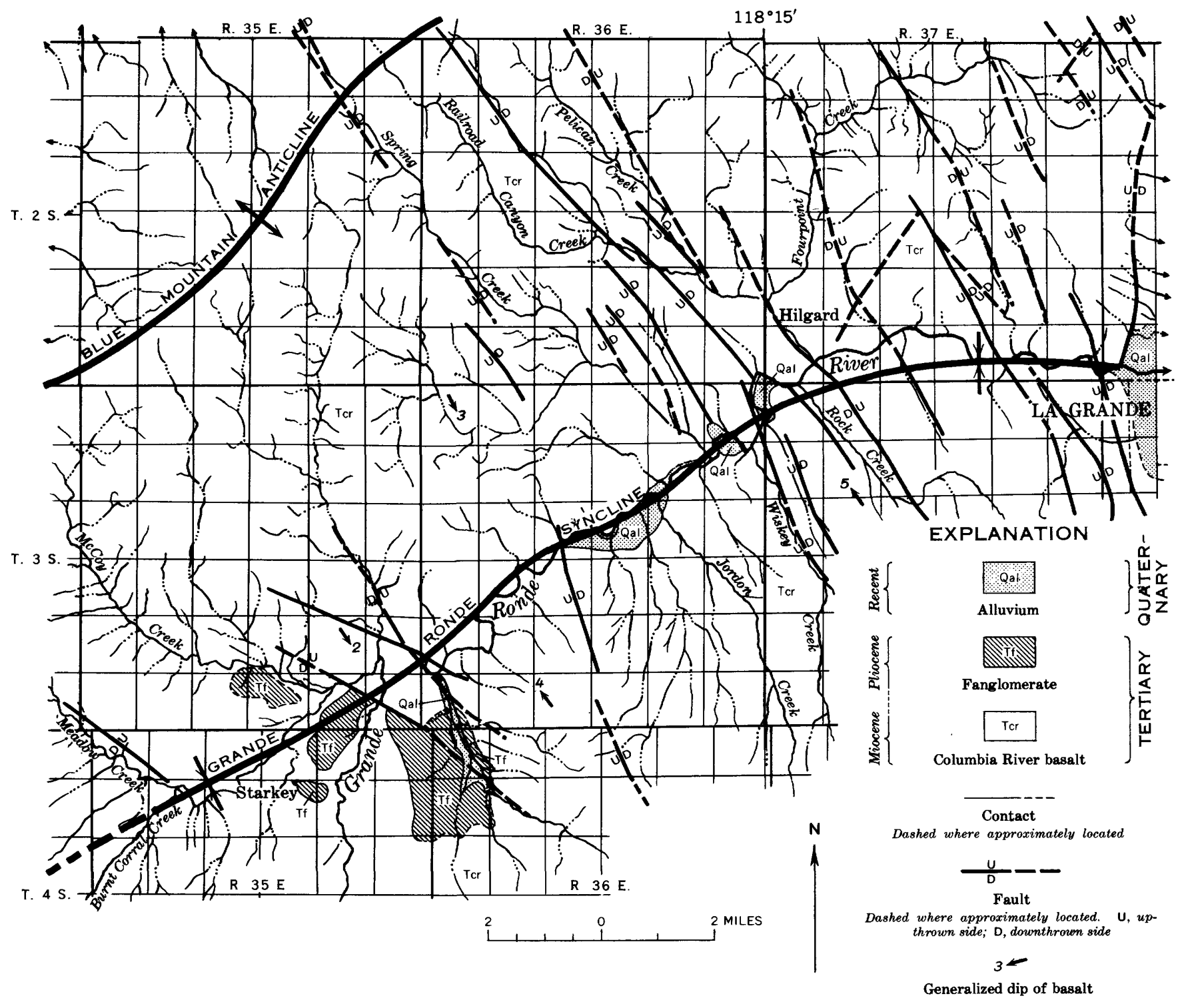

Figcre 8.-Geological map of the Grande Ronde River valley above La Grande, Oreg. (From Hampton and Brown, 19.i9.)

SUGGESTIONS AS TO GENERAL SPECIFICATIONS FOR TEST WELLS

The dip of the layers of the basalt in most of the stream valleys where testing is proposed ranges from $1^{\circ}$ to $5^{\circ}$ and averages $2^{\circ}$ to $3^{\circ}$ downstream, or an average of 200 to 300 feet per mile. This average dip, together with a stream gradient of about 50 to 75 feet per mile, indicates that a 300 -foot well would intercept the permeable zones that crop out in the first mile of the river above the well. Because different hydrostatic pressures probably exist in different aquifers, those of greater depth generally having the higher pressures, it is undesirable for one well to develop water from more than one aquifer or from more than one group of aquifers having similar hydrostatic pressures. Neglect of this precaution may lead to waste of reservoir water through aquifers of lower pressure. Consequently, the pairing of wells, one approximately 300 and one 600 feet deep may be a desirable arrangement for the testing of each barrier reservoir. In places where the basalt is thick and the reservoir is to be fully developed, a third well, about 1,000 feet deep, may be needed during later productive operation (fig. 9 ).

The proper evaluation of the effect that the use of a ground-water reservoir will have on the nearby stream necessitates gaging the stream. The cost of establishing stream-gaging stations and operating them will be lessened if several nearby wells are served by one station. Also, savings on other surface facilities may be possible by grouping the wells producing water from different depth zones in one barrier reservoir. However, because one well can partly establish the presence 


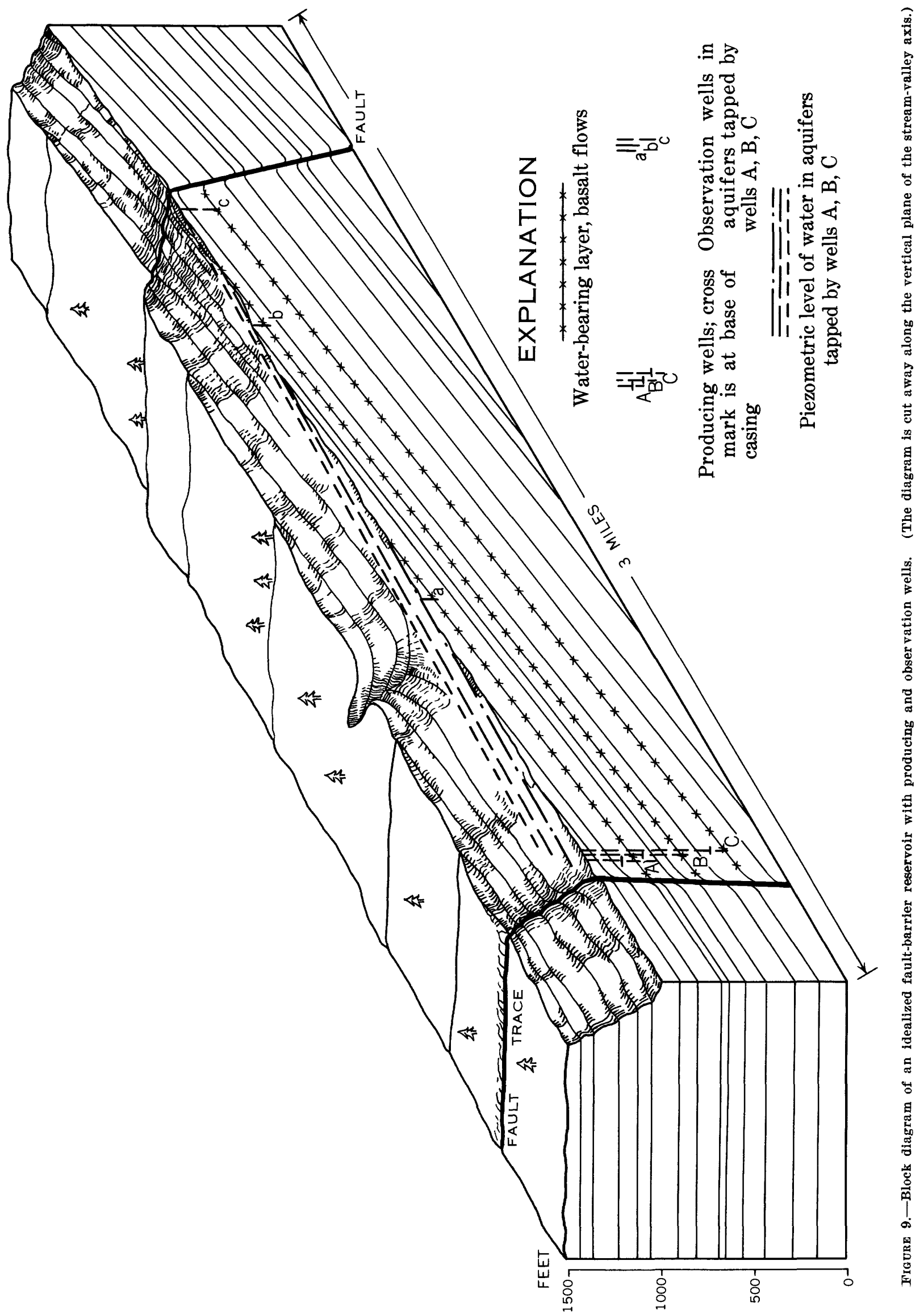


and utility of a reservoir, it is probable that the initial testing of reservoirs will be by means of single wells.

To serve the intended purpose, the wells must be properly cased. As the geologic conditions foreseen in these reservoirs indicate successively greater water pressure with successively greater depth, the sealing of upper aquifers of relatively low pressure head will be necessary in some wells. Some possible arrangements of casing are shown in figure 10. Casing should be equal at least to standard well casing having a minimum wall thickness of 0.33 inch. It should be sealed to the impermeable parts of the rock by grouting with cement. The construction and arrangement of a permanent producing well should be planned to obtain at least a 100 -year use before recasing is necessary.

The surface appurtenances must include proper valve equipment, frost-protection outlets, fireproof protective shelters, and flood-damage protection. Equipment for measuring the flow of the well and the flow of the stream passing the well must be included. Facilities for recording these measurements and keeping the records also must be provided.

At least one observation well is necessary in each reservoir during the test period and after full develop- ment. One 6-inch observation well located upstream from each producing well may be necessary during ultimate full use of a reservoir.

\section{TEST OPERATION OF THE WELLS}

The operation is foreseen as a flow or, if necessary, a pump discharge from the wells in the general period July 1 to November 1 of most years and a period of shut down to allow recovery during the remainder of the year. Records of the discharge of the wells, the temperature of the water, and the flow of the adjacent stream are to be taken during the 4-month period of use. Records of water level, or water-pressure level, in the wells and the discharge of the nearby stream are to be maintained throughout the year. The facts regarding water-level recovery in the aquifers will determine the amount of water that can be extracted from each barrier reservoir and also the rate and timing of the extraction.

The siructural reservoirs suitable for testing include both the type in which the aquifer crops out in the bed of either a permanent or an intermittent stream, and the type in which it does not. The draining of a barrier
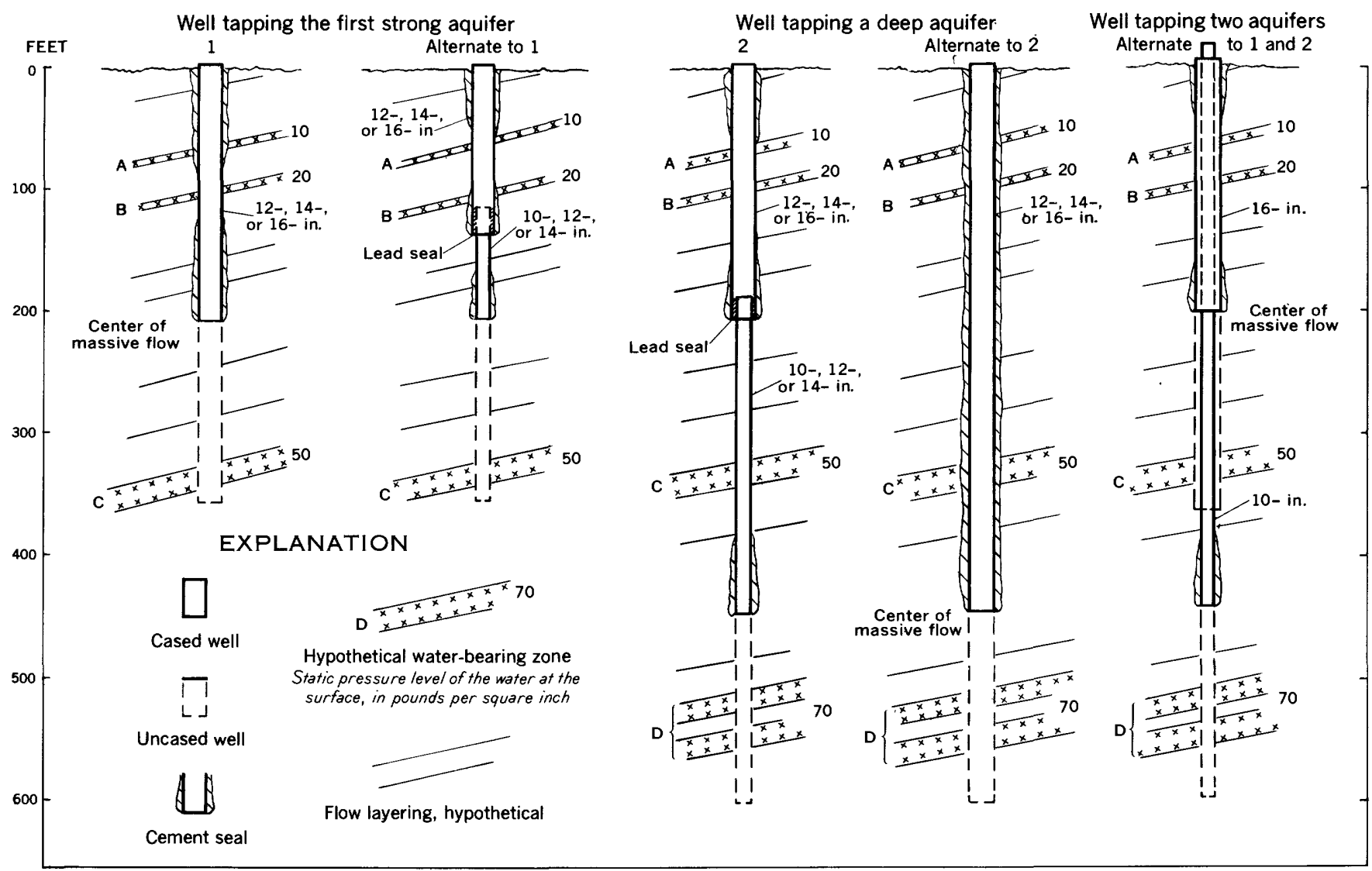

Frgure 10.-Schematic diagram of some possible arrangements of casing and wells to tap water stored in a barrier reservoir in basalt. 
reservoir is expected to induce some recharge as a diversion from any flowing stream that crosses the outcrop of the aquifers. Consequently, the withdrawal of water from storage will be expected to cause some decrease in streamflow downstream from the outcrop of those aquifers. However, the amount of water tapped from storage in the reservoir is expected to be many times the amount of streamflow depletion induced during the period of well operation. The subsequent refilling of the ground-water reservoir, partly by continued seepage from the stream, would occur during the fall and winter runoff period when such diversion from the stream is either beneficial or nondetrimental (fig. 11). It is expected that bedload movement and channel scour will continue the effective infiltration of water at the streambed outcrop of a depleted aquifer.

The possibility of artificial recharge to augment natural infiltration is present but, for brevity, is omitted from this report. Presumably, artificial recharge of clean water could be achieved by pumping water through injection wells during the period of reservoir recovery.

The approximate amount of streamflow depletion during the period of well use can be calculated, for idealized conditions, by the use of the Theis nonequilibrium equation (Theis, 1935). The effect of the barrier on the lowering of the water level at both the pumped well and the outcrop of the aquifer is computed from that equation and adjustments derived from the laws governing the drawdown of the water level in image wells (Ferris, 1949).

Under the assumed conditions of a producing-well system such as is shown in figure 12, and on the basis of conservative coefficients of transmissibility and storage, a withdrawal of $1,000 \mathrm{gpm}$ for 120 days would result in a drawdown $\cap$ f about 140 feet at the producing well and of 50 feet at the outcrop of the aquifer. In these calculations the coefficient of transmissibility was assumed to be 25,000 gallons per day per foot and the coefficient of storage to be $0.0001 .^{1}$

If there is 50 feet of drawdown at the outcrop of the aquifer, the ground-water surface would have a generally downstream gradient of 20 feet per mile by the end of 120 days. Theoretically, this drawdown at the outcrop should induce infiltration ranging from 10 gpm at the beginning of the pumping season to 250 gpm at its end. Because the calculated 140 feet of drawdown exceeds the 100 feet of hydrostatic pressure

\footnotetext{
1 The coefficient of transmissibility is defined as the number of gallons of water that will pass in 1 day, under prevailing conditions, through a vertical strip 1 foot wide extending the height of the aquifer under a hydraulic gradient of 1 foot in 1 foot. The coefficient of storage of an aquifer is the volume of water it releases from or takes into storage per unit surface area of the aquifer per unit change in the component of head normal to that surface.
}

at the beginning of the test, this well would need to be pumped near the end of the season or the flow be reduced to a seasonal average of about $700 \mathrm{gpm}$. So many unknowns and assumptions based on scant data are included in these calculations that their only significance is that they show general quantitative agreement with the results estimated from a qualitative approach.

\section{ESTIMATED COST OF A PROPOSED TEST INSTALLA- TION AND TEST PROCEDURE}

The necessary test wells should include both shallow and deep wells, both of which are foreseen as the ultimate outlets of water from barrier reservoirs.

Assuming that each reservoir will ultimately be developed by at least one well 300 to 400 feet deep paired with a well 600 to 700 feet deep, the depth of 4 test wells is estimated to total 2,000 feet. When completed with proper casing and sealing, each of these wells, of $14-, 12-$, and 10-inch diameter, may cost about $\$ 25$ per foot. Valves, meters, aeration trays (for absorption of oxygen, where needed), and other appurtenances are estimated to cost $\$ 2,000$ per well. Observation wells of 8- to 4 -inch diameter located about midway between producing wells and the outcrop of the aquifer should be planned near 2 of the 4 well sites. Each would cost about one-fourth as much as a producing well.

A station for accurate gaging of the nearby stream is estimated to cost an average of $\$ 5,000$, which includes the cost of the installation and the first year's operation. Such a gaging station would serve one barrier-reservoir installation, whether single, twin, or triple wells are used, but even if only one test well is drilled at each barrier tested, the cost of one stream-gaging station will need to be included in the cost of development for each barrier reservoir.

On the basis of 1959 prices, the estimated cost of testing four barrier reservoirs with single producing wells is:

Drilling casing, and completing 4 wells, total length 2,000 feet, at $\$ 25$ per foot_________._ $\$ 50,000$

Appurtenances -

Observation wells, 4_- 12,000

Stream-gaging station (including cost of first year of test), 4 20,000

Total $\$ 90,000$

Thus, the cost of testing 1 barrier reservoir on a singlewell basis would be about $\$ 22,500$.

The estimated annual operating cost at 1 test reservoir thereafter is about $\$ 1,000$, on the assumption that the operation would be under the supervision of a county watermaster or similar official. It is assumed that most of the cost is that of gathering the hydraulic data, and at any reservoir this cost would be about the same, 

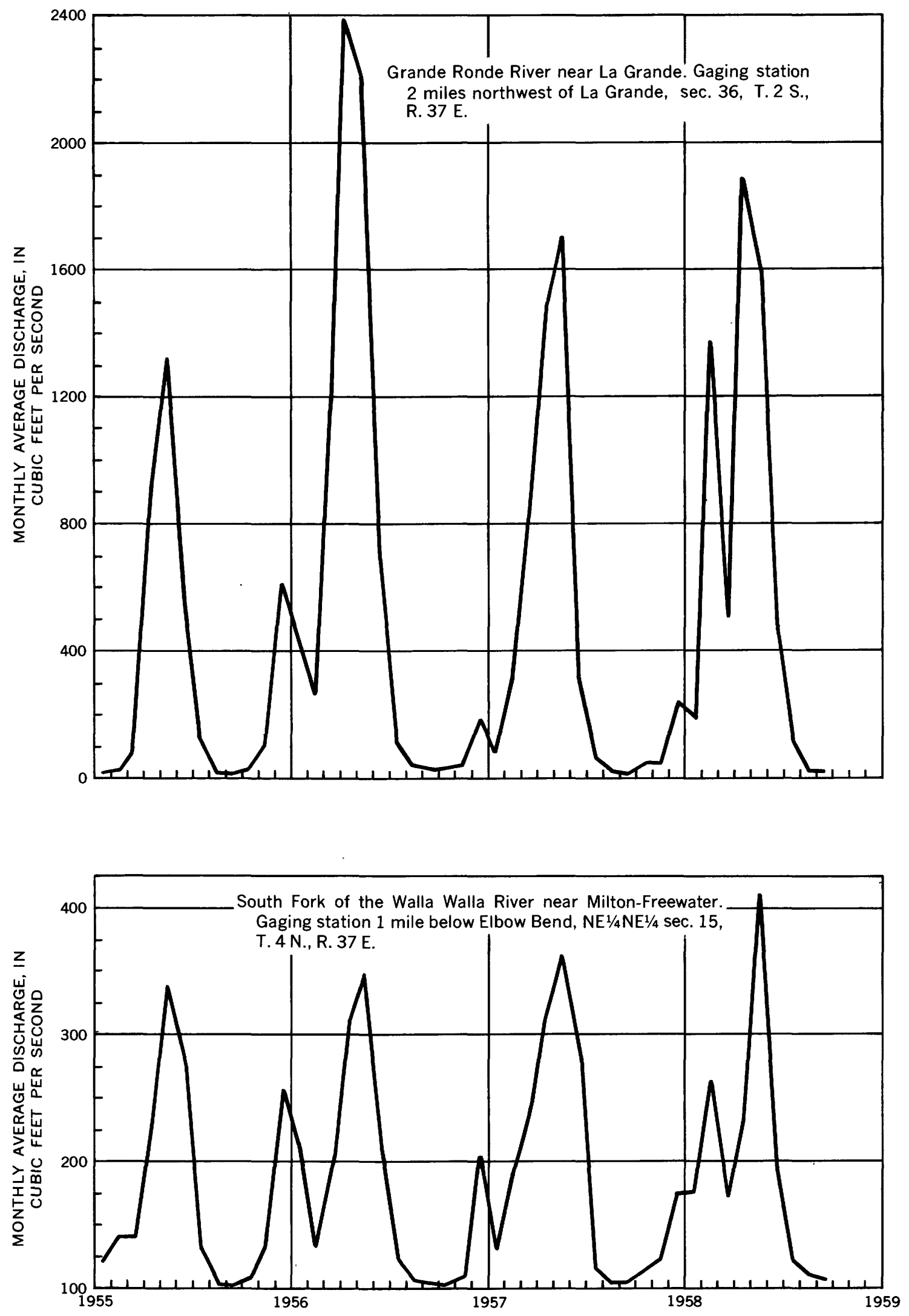

Figure 11.-Average monthly discharge in two rivers where structural reservoirs of ground water are believed present for artificially augmenting the annual low flow. 


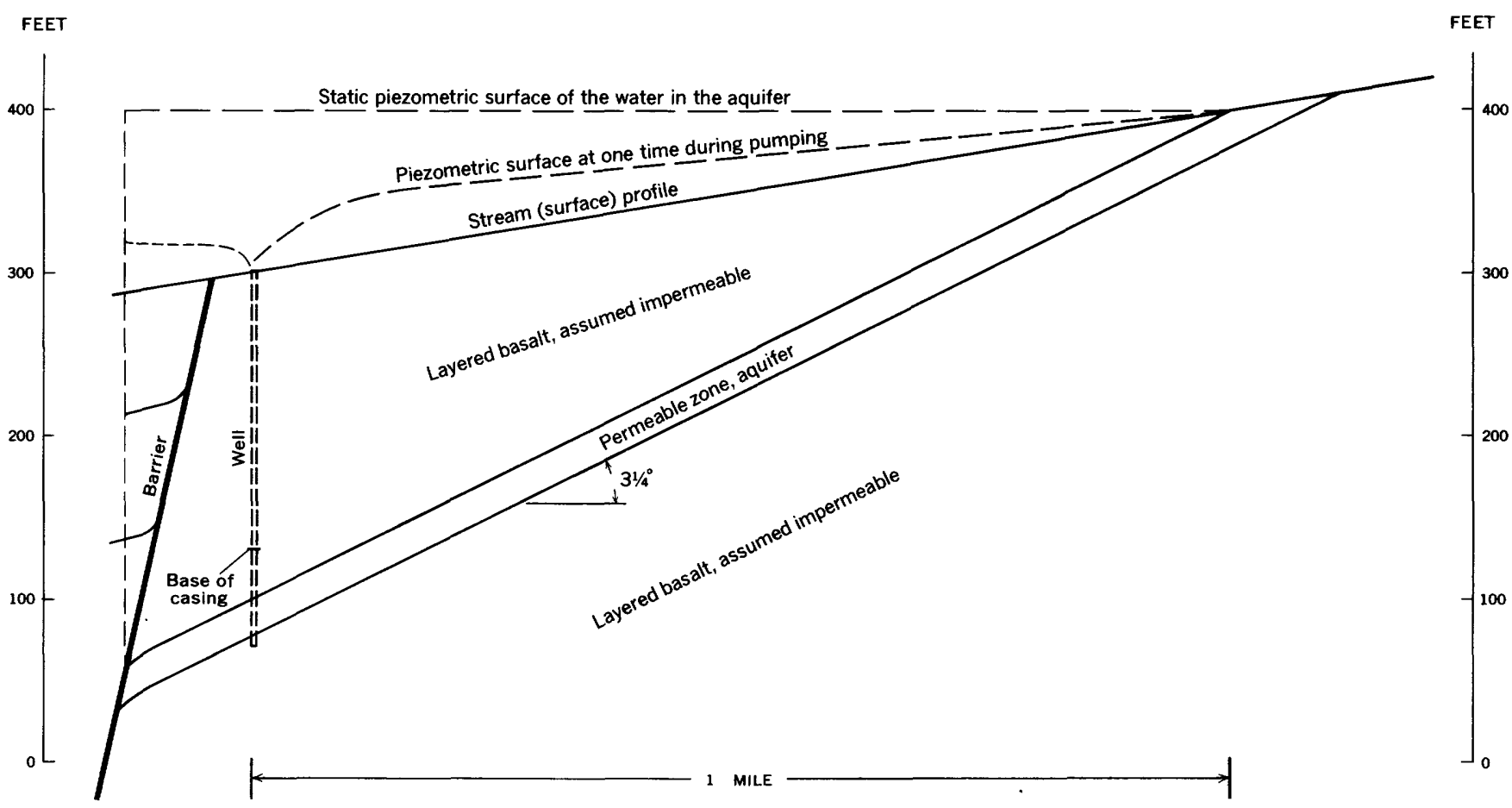

FIGURE 12.-Cross section of a hypothetical ground-water-withdrawal system utilizing an aquifer of a barrier reservolr.

regardless of the number of wells used. Thus, ultimate full production at each reservoir may not entail an average operational cost of much over $\$ 1,000$ per year.

In these estimates the cost of pumping is omitted, because one objective in the location of the test sites would be to secure free-flowing wells where pumping costs would be avoided.

\section{VALUE OF THE BENEFITS DERIVED}

By continuing a hypothetical average well yield of $1,000 \mathrm{gpm}$ over 120 days and assuming that 80 percent is new water previously unavailable, a total of 425 acre-feet of new water would be made available by each well. At $\$ 8$ per acre-foot, the value of this water for irrigation purposes would be about $\$ 3,400$ per year.

At some sites, where a hydroelectric plant would use the water at 200 feet gross head, this 1.75 cubic feet per second of new water in 120 days of the low-flow period would generate 67,000 kilowatt hours of electricity, which, at $\$ 0.007$ per kilowatt hour, would have a value of $\$ 470$ per year.

It is difficult to compute the value of the new water for fish culture, especially for the improvement of otherwise good spawning reaches that lack an adequate summer flow, as does the Grande Ronde River between Starkey and La Grande, Oreg. The value of the new water for such uses as recreation, public and domestic supply, abatement of pollution, and watering of livestock is also difficult to assess at this time.

These conservative estimates show that the wells would yield new water that annually would exceed in value the operating costs and at least 5 to 10 percent of the capital investment.

\section{REFERENCES CITED}

Ferris, J. G., 1949, Ground water, in Wisler, C. O., and Brater, E. F., Hydrology: New York, John Wiley and Sons, p. 198-272, figs. 62-98.

Hampton, E. R., and Brown, S. G., 1959, Geology and groundwater resources of the Upper Grande Ronde River basin, Union County, Oreg.: U.S. Geol. Survey open-file report.

Hart, D. H., 1958, Tests of artesian wells in the Cold Creek area, Washington: U.S. Geol. Survey open-file report.

Newcomb, R. C., 1951, Preliminary report on the ground-water resources of the Walla Walla basin, Washington-Oregon: U.S. Geol. Survey open-file report.

1959, Some preliminary notes on ground water in the Columbia River basalt: Northwest Sei., v. 33, no. 1, p. 1-18.

Piper, A. M., 1932, Geology and ground-water resources of The Dalles region, Oregon: U.S. Geol. Survey Water-Supply Paper 659-B, p. 107-189, pls. 11-19.

Theis, C. V., 1935, The relation between the lowering of the piezometric surface and the rate and duration of discharge from a well using ground-water storage: Am. Geophys. Union Trans., pt. 2, p. 519-524. 
Storage of Ground Water

Behind Subsurface Dams in

the Columbia River Basalt

Washington, Oregon, and

\section{Idaho}

By R. C. NEWCOMB

HYDROLOGY OF VOLCANIC-ROCK TERRANES

GEOLOGICAL SURVEY PROFESIONAL PAPER 383-A

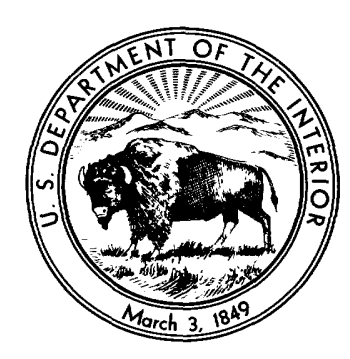

UNITED STATES GOVERNMENT PRINTING OFFICE, WASHINGTON : 1961 
UNITED STATES DEPARTMENT OF THE INTERIOR

STEWART L. UDALL, Secretary

GEOLOGICAL SURVEY

Thomas B. Nolan, Director

For sale by the Superintendent of Documents, U.S. Government Printing Office Washington 25, D.C. 


\section{O N T E N T S}

\begin{abstract}
.
Introduction

Environment of the barrier reservoirs of ground water---

Occurrence of ground water in the basalt . . . . .

Tectonic deformation of the basalt .............

Tilting and warping

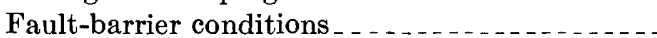

Reservoirs behind structural barriers Structural conditions creating barrier reservoirs. Known and tested structural reservoirs

Undeveloped structural reservoirs

Sites proposed for testing for impounded ground

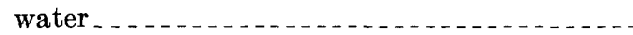

Pag
-1
1
2
3
3
5
5
6

Page

Plan for test development of barrier reservoirs of ground water.

Test-well location Suggestions as to general specifications for test wells_ Test operation of the wells .................... Estimated cost of a proposed test installation and test procedure.........................................

Value of the benefits derived....................... References cited $\mathrm{A}-8$

8

10

12

13

15

\section{ILLUSTRATIONS}

Figure 1. Map showing the main area underlain by the Columbia River basalt

2. View northwest down the valley of the South Fork of the Walla Walla River.

3. View of a fault zone exposed by a road cut in the northwest bluff of the Grande

4. Close view of figure 3 , showing shearing common to fault zones in the basalt

5. Block diagrams of idealized fault barriers .

6. Map of area adjacent to The Dalles, Oreg., showing fault barriers

7. Geologic map of the upper part of the Walla Walla River basin

8. Geologic map of the Grande Ronde River valley above La Grande

9. Block diagram of an idealized fault-barrier reservoir

10. Schematic diagram of some possible arrangements of casings and wells to tap water stored in a barrier reservoir

11. Graphs of the average monthly discharge in two rivers where structural reservoirs of ground water are believed present. . . . . .

12. Cross section of a hypothetical ground-water withdrawal system utilizing an aquifer of a barrier reservoir $\ldots . . . . .-$ 


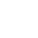




\section{HYDROLOGY OF VOLCANIC-ROCK TERRANES}

\section{STORAGE OF GROUND WATER BEHIND SUBSURFACE DAMS IN THE COLUMBIA RIVER BASALT, WASHINGTON, OREGON, AND IDAHO}

By R. C. Newcoms

\section{ABSTRACT}

The Columbia River basalt, a thick sequence of accordantly layered lava flows, forms the bedrock beneath about 50,000 square miles in Washington, Oregon, and Idaho.

The rubbly rock at the top and bottom of some of the flows is permeable and transmits water laterally between the flows. Where the strata are displaced vertically by faults, barriers to movement of the water are common. Where these barriers are transverse to the dip of the basalt layers, ground-water reservoirs are formed. Many such reservoirs are present in mountainous areas or on the flanks of mountain uplands, and their water has been little used to date.

Properly designed and constructed test wells are suggested as a means of determining the feasibility of withdrawing water from these reservoirs during the growing season and allowing the reservoirs to refill during the winter and spring. Benefits from such a practice may be especially great in stream valleys where water is needed in the late summer.

\section{INTRODUCTION}

Data gathered in studies of ground water in the Columbia River basalt have made it increasingly clear that, in places, the basalt contains replenishable bodies of water in virtually "dead" storage. Structural barriers, which impede the movement of ground water, are the cause of one type of ground-water reservoir. Some of these reservoirs are in upland or mountainous areas, where the stored water would be available for use during the months of low streamflow each year. Though the amount of water that might be withdrawn annually from any one reservoir may be a modest few hundreds or thousands of acre-feet, the total may be a very important addition to water resources in areas where water is greatly needed.

The existence of these upland reservoirs has been noted in previous reports. This paper is intended to indicate more explicitly their mode of occurrence and to outline a possible method of making tests to determine what part of the water might be replen- ishable. The paper is intended also to estimate the costs of testing and to point out some of the benefits to be derived from the development of this stored water.

Because the proposed test wells would be of the same type as the operational producing wells tapping these reservoirs, they should be constructed as though they were to be merely the first of the permanent producing wells; many features of the foreseen operational-well installations have been incorporated in this method for testing the reservoirs.

The water to be withdrawn from such a reservoir is referred to as "new" water because it would otherwise be unavailable. Under the assumptions of this plan, the water taken from storage as new water during the months of greatest need would be replaced during the winter and spring when runoff is in excess of needs.

The presence of these reservoirs has been noted in several reports on local areas, and there have been many inquiries for additional information and for suggestions on suitable methods of development. This plan for testing and the suggested procedure for any subsequent development of these reservoirs carry no implications as to who might undertake that work. If the first tests show development to be feasible, many organizations may be interested in the use of such reservoirs.

The paper was prepared under the Federal project for study of the hydrology of the Coluribia River basalt. Much of the supporting information is contained in reports on areas studied in cooperation with the State Engineer of Oregon, the Department of Conservation of Washington, and other local agencies.

\section{ENVIRONMENT OF THE BARRIER RESER- VOIRS OF GROUND WATER}

The Columbia River basalt is a thick sequence of accordantly layered lava flows of basaltic and basic andesitic composition. The main part underlies most 


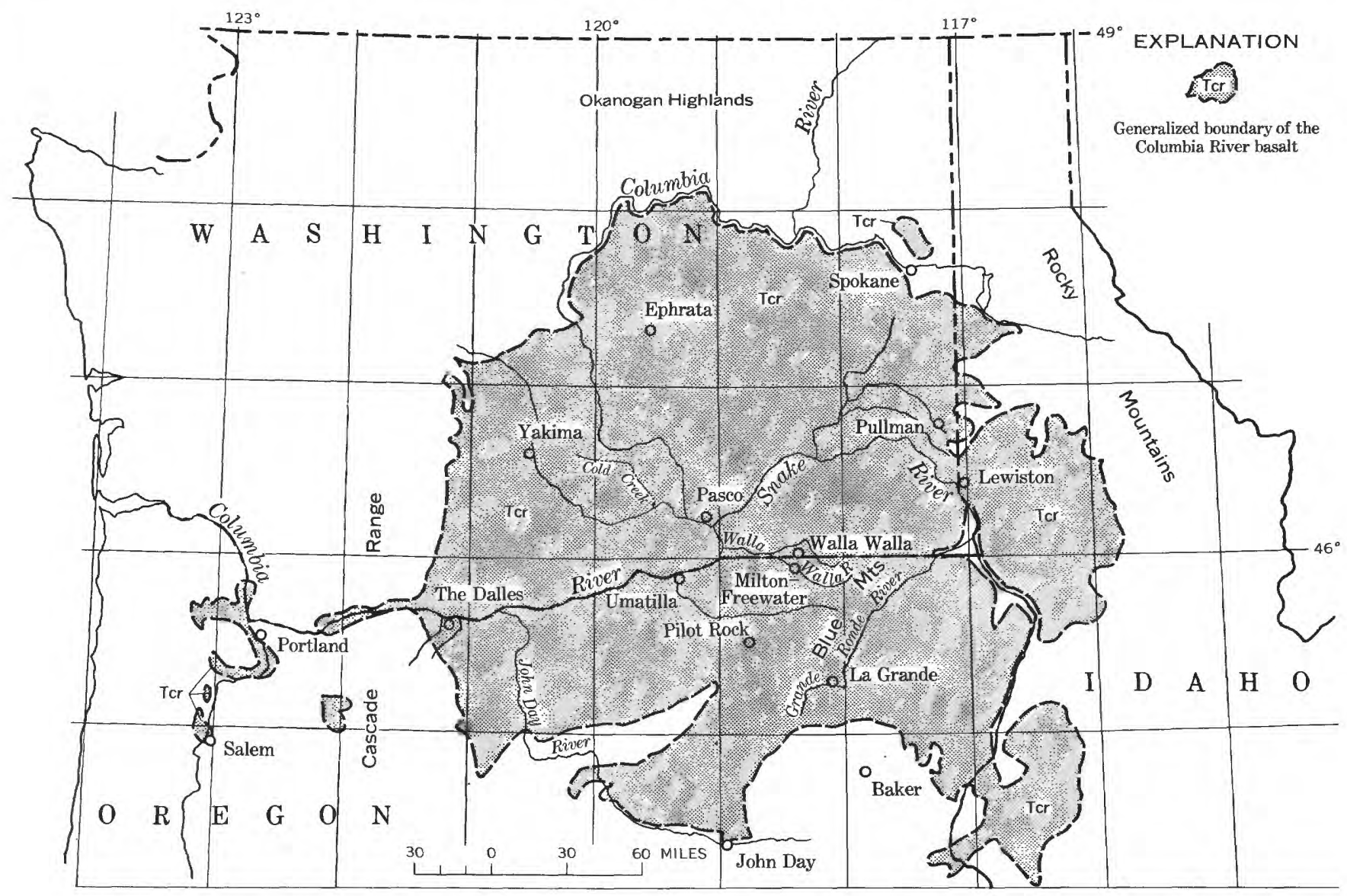

Figure 1.-Map showing the main area underlain by the Columbia River basalt, Washington, Oregon, and Idaho.

of the area that extends westward from the northern Rocky Mountains to the northern Cascade Range, and southward from the Okanogan Highlands to the mountains of central Oregon (fig. 1). In the central part of this area the basalt is known to be more than 5,000 feet thick in places, and it tapers to zero on the older rocks at its margins. The individual lava flows range in thickness from 5 to 150 feet and average about 50 feet. The average flow consists of dense, almost flintlike, partly fractured rock at its base; grades vertically to dense, massive columnar-jointed rock at its center; and then to vesicular-and in some places rubbly-rock at its top. Systems of fractures cut the rock into irregular columnar, cubical, and platy blocks that range from 2 to 60 inches across; the fractures formed when the lava was cooling.

\section{OCCURRENCE OF GROUND WATER IN THE BASALT}

Ground water moves through the rock largely in the permeable zones at the top of some flows. These tabular zones commonly are about 3 to 10 feet thick. In places where 2 of these permeable interflow zones are separated by highly jointed lava, the total thick- ness of a single water-bearing stratum may be 25 feet or more.

The massive centers of some flows are relatively impermeable, and in places thick zones of the rock consist of several successive flows which are tight and nonwater bearing. Above the water table, these impermeable zones cause water to be perched, and below that level, in places, they cause the water-bearing zones to have no hydraulic continuity and, therefore, to have different water-pressure levels. Also, where the basalt is tilted or where the water movement is impeded by barriers, the water below these impermeable zones may be confined under pressure.

Exact data are lacking not only on the percentage of interflow zones that are permeable and on their average water-yielding capacities, but also on their average thickness and permeability. These factors have been partly evaluated in a computation of the yield of water to an average well. A computation made by the writer in 1947 , based on records of several hundred wells that penetrated 300 feet or more of the basalt, shows that 1 gallon of water per minute for each foot of well that is below the regional water 
table is the approximate average yield obtained by a 10- or 12-inch well when pumped at the common drawdown of 50 to 100 feet (Newcomb, 1959). Subsequent records show that this estimated average is conservative for the yields obtained from the better designed wells now being constructed.

Data indicate that the average capacity of the basalt to transmit ground water is generally uniform to a depth of about 1,500 feet, where the basalt is that thick. Not enough wells have been drilled deeper than 1,500 feet to warrant making estimates of the average permeability of the basalt below that depth.

\section{TECTONIC DEFORMATION OF THE BASALT}

\section{TILTING AND WARPING}

The basalt was extruded, in Miocene and Pliocene(?) time, as nearly horizontal flows. Subsequently, it was warped during at least two periods of folding. In most places, the basalt is now tilted in broad warps of the earth's crust. The general pattern of the regional tilting includes gentle dips inward from the older rocks near the boundary mountain ranges, a series of anticlines and intervening synclines that extend through central Washington eastward from the Cascade Range, and a broad anticline-known as the Blue Mountain anticline-that curves northeastward from the mountains of central Oregon. There are also many local structures. (See fig. 2.)

Because ground water, which has percolated into the basalt, finds the easiest path of travel in the permeable interflow zones, it moves generally down the dip of inclined strata. Thus, in general, the anticlines cause water to transfer laterally into the downwarped synclines, which are gathering places for the ground water in the basalt. Consequently the water table, or the piezometric surface of the ground water, beneath areas of inclined basalt commonly lies at or near the level of the principal streams. In synclines the water table may lie at or near the drainage level, or the ground water may be confined under artesian pressure.

Most of the highly productive wells in the basalt are in downwarps such as occur at Walla Walla, Cold Creek, and Ephrata, Wash.; The Dalles, Umatilla, and Pilot Rock, Oreg.; and Lewiston, Idaho.

\section{FAULT-BARRIER CONDITIONS}

During the deformation of the basalt, bending did not relieve all the stress in the rock at some places. Locally, these unrelieved forces produced fractures, called faults, along which the rocks on opposite sides were displaced. These faults range from large shear fractures along which the rocks on opposite sides were displaced several thousand feet, to small ones where



Figure 2.-View northwest from the Blue Mountain upland near McIntyre Lookout, Oreg., down the valley of the South Fork of the Walla Walla River, where the downstream dip of the basalt is apparent. 


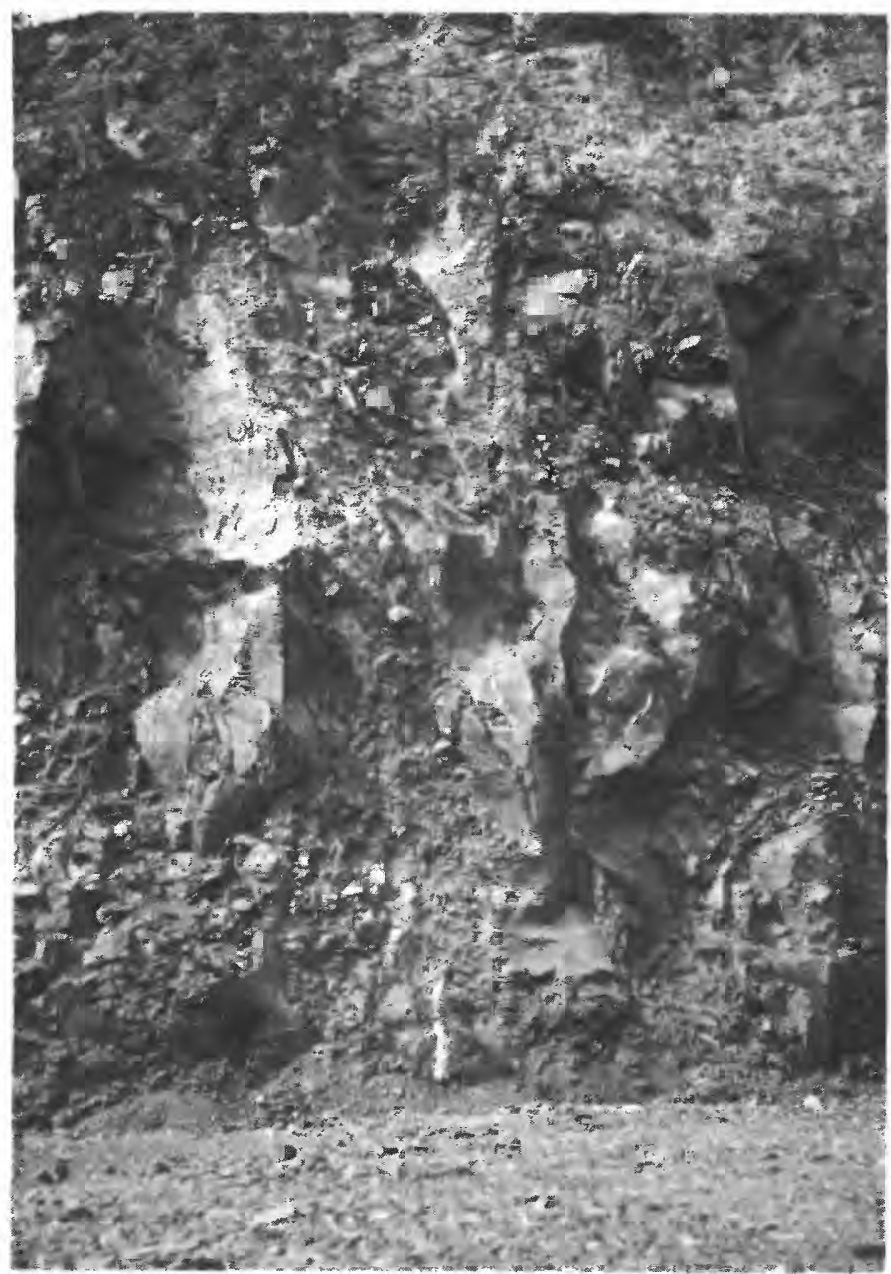

Figure 3.-View of a fault zone exposed by a road cut in the northwest bluff of the Grande Ronde River above La Grande, Oreg., in sec. 31, T. 2 S., R. 37 E.

little displacement occurred. Rather than a single plane of fracture, the larger faults consist of zones of shattered and broken rock several tens or hundreds of feet wide (fig. 3). Even some of the small faults, along which the displacement is measured in tens of feet, are zones of sheared and shattered rock.

Nearly all the faults are of the type commonly called normal faults, in which the fracture plane dips toward the downthrown side. This type generally is considered to indicate that tensional strains were responsible for the faulting. The most common inclination, or dip, of the fracture planes is between $60^{\circ}$ and $70^{\circ}$ below the horizontal.

The water-transmission characteristics of the fault zones differ considerably from those of the unbroken basalt. The fault fracturing provides a zone of low permeability (fig. 3), along which small amounts of water can move vertically in some places. The lowest sags in the fault traces, where they cross stream valleys,

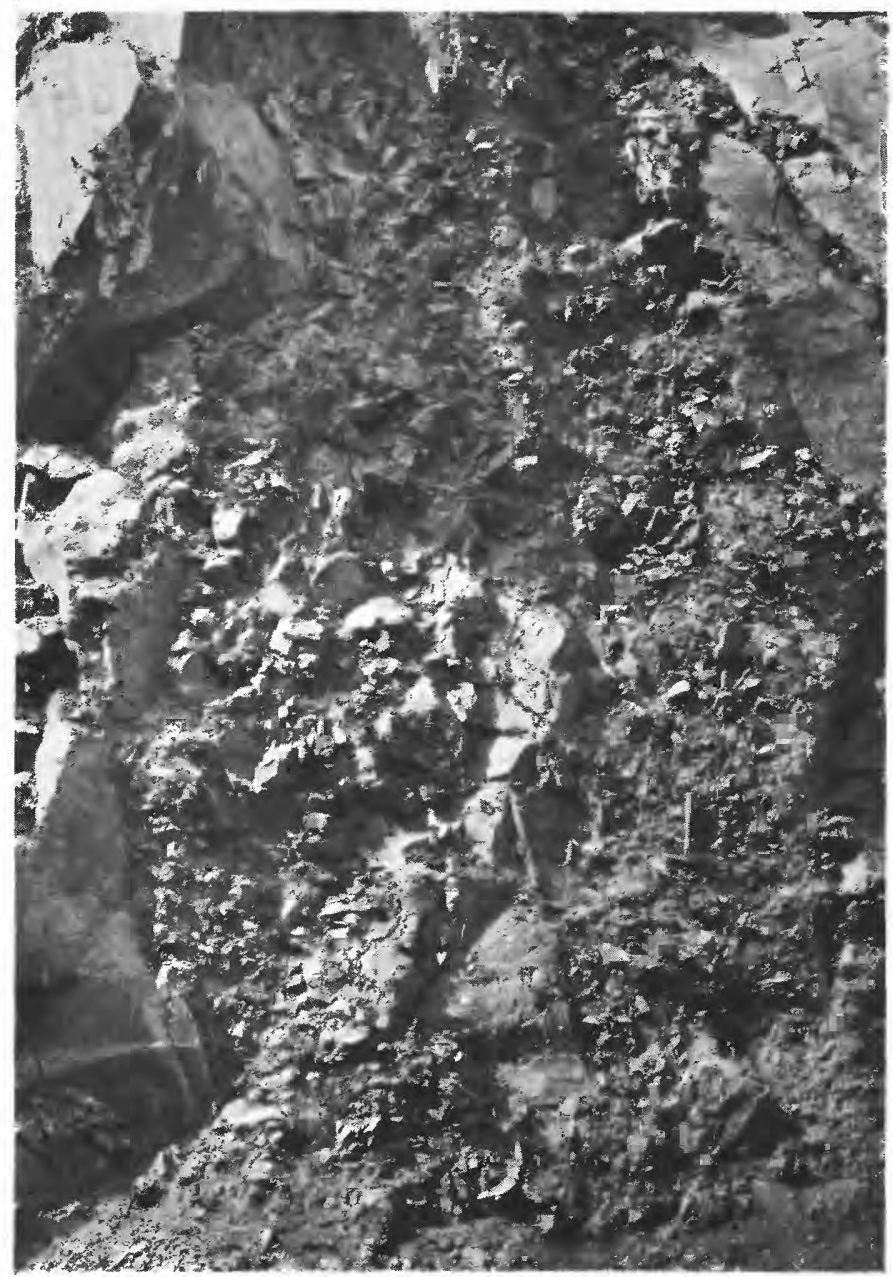

Figure 4.-Close view of part of figure 3 showing the shearing common to fault zones in the basalt. (Pick, at lower right of the center, is 14 inches long.)

are generally marked by small seepage springs. The permeable interflow zones that provide the lateral, or generally horizontal, routes of ground-water movement are obliterated in the fault zones and the lateral movement of the water is virtually stopped. Thus, a fault zone constitutes a barrier to the otherwise normal lateral movement of ground water.

In addition to those created by faulting, barriers can occur also along the axis of sharp folds owing to disruption of the permeable zones by the interflow grinding as the rock stretched over sharp bends of the basalt. These two types of localized destruction of the tabular paths of lateral movement of water in the basalt are grouped together under the term "structural barriers" (Newcomb, 1959). Intrusive dikes can also form barriers. However, dikes are not so numerous or so continuous as the structural barriers, and in many places they are not arranged transverse to the direction of ground-water movement. 


\section{RESERVOIRS BEHIND STRUCTURAI BARRIERS}

\section{STRUCTURAL CONDITIONS CREATING BARRIER} RESERVOIRS

If a fault zone is parallel to the direction of groundwater movement, it has little effect on the lateral movement of the water. However, if the fault zone is transverse to the direction of movement, the percola- tion down the gradient may be blocked and the water deflected around it; or, if the fault is extensive, the water may be dammed and may reach the surface above the barrier (fig. $5 \mathrm{~A}$ ). Thus, if a fault zone crosses the axis of a syncline, an almost complete barrier may be formed (fig. $5 B$ ). Surface outlets (and inlets) commonly occur at the points where the individual water-

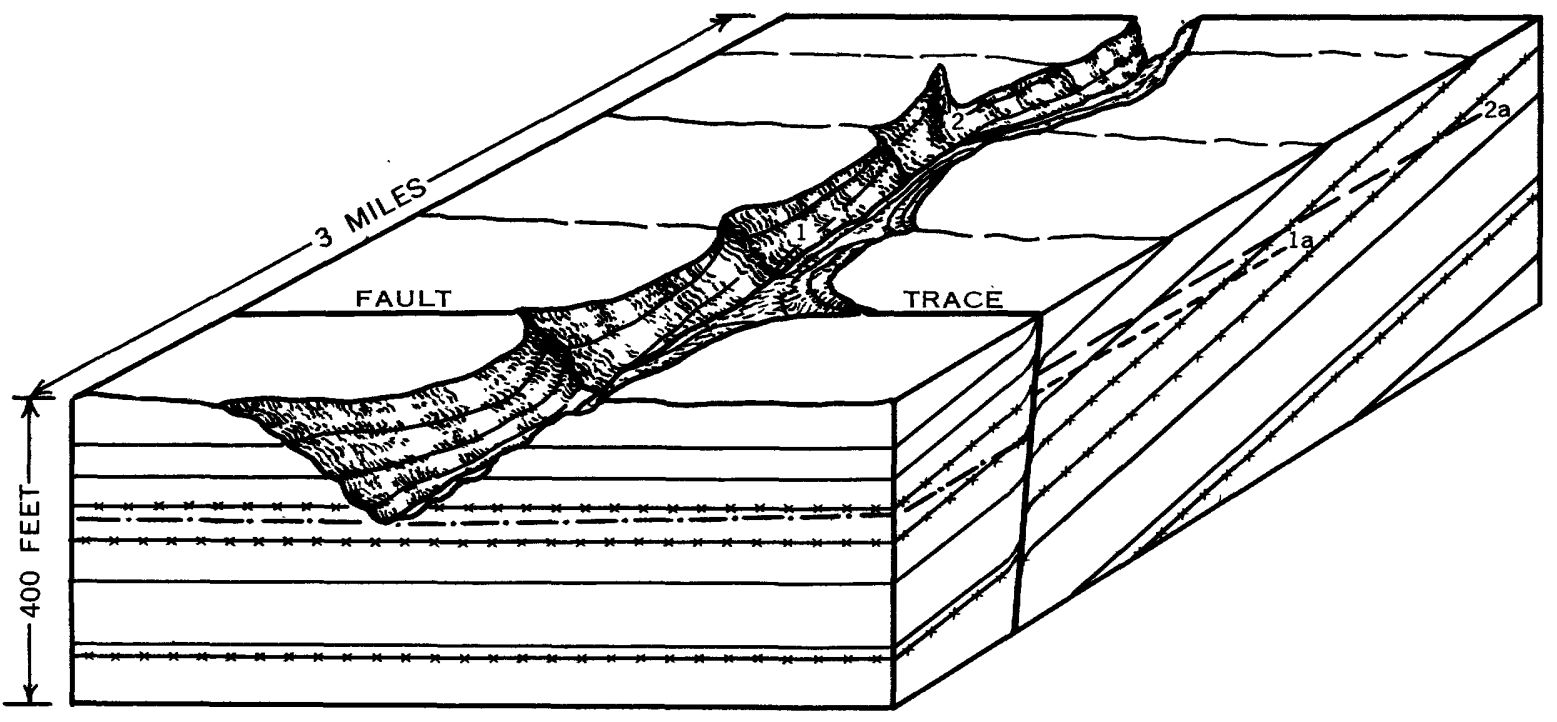

A. A monoclinal dip of the basalt cut

by a transverse fault barrier

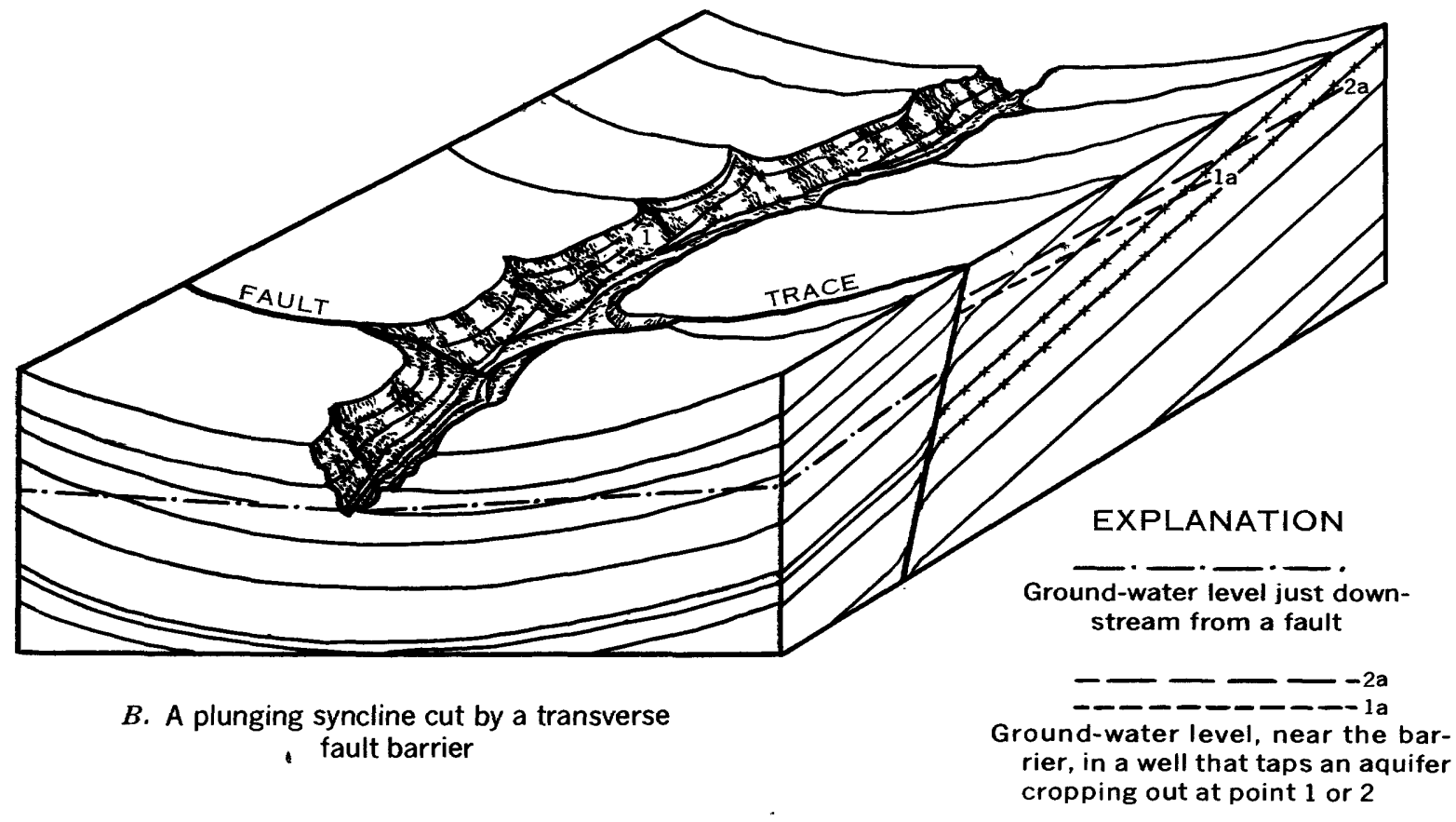

Water-bearing layer shown on the sides of the diagrams

FIGURE 5.-Structural features creating barrier reservoirs, 
bearing zones crop out in streambeds above the barrier. The outlets of some reservoirs may occur also at other points in the streambeds upstream from the fault zone, because of upward cross-strata leakage from the aquifer.

\section{KNOWN AND TESTED STRUCTURAL RESERVOIRS}

In the quest for water in the Columbia River basalt, several ground-water reservoirs of the type described have been tapped by wells. Some reservoirs have been rather thoroughly developed and their extent and mode of occurrence are well defined. Others have been less well developed, and some have been tapped by only a few wells or by a single well.

Possibly the most thoroughly developed groundwater reservoir of this type is that impounded behind the fault or sharp fold which passes through the basalt bedrock north of College Place, Wash., in the Walla Walla syncline. The fault or sharp fold is marked by a 200 -foot-high ridge in the bedrock surface beneath the 500 feet of sedimentary deposits which underlie the valley floor. The ridge trends east-northeast across the broad slope of part of the south limb of the Walla Walla syncline. It marks a vertical barrier to the lateral movement of ground water. When the first wells were drilled, during the years 1900-10, the artesian head of the water in the deep wells tapping the uppermost 200 feet of the basalt on the upgradient side of this barrier was about 140 feet above the land surface and 200 feet above the level of the water table in the nearby wells tapping the same rocks on the downgradient side of the barrier (Newcomb, 1951).

Another developed reservoir upgradient from a fault (or sharp fold) occurs in the Upper Cold Creek syncline east of Yakima, Wash. The main part of the reservoir area lies in secs. $25,26,27,34,35$, and $36, \mathbf{T}$. 13 N., R. 24 E., and secs. 30 and 31, T. 13 N., R. 25 E. (Hart, 1958). The lower part of this plunging syncline is mantled by sedimentary deposits, which continue eastward beneath the high terraces in the Hanford Reservation of the U.S. Atomic Energy Commission. The ground-water reservoir of artesian water terminates abruptly in alinement with the sharp east edge of the Yakima Ridges to the north and south of the syncline. The easternmost well, the McGee, is about a quarter of a mile upslope from the inferred location of the barrier. Originally, the pressure level of the ground water at the McGee well was 212 feet above the land surface and about 580 feet above the level of the ground water in the basalt east of the barrier.

An area south and southwest of The Dalles, Oreg., has several partly known ground-water reservoirs behind fault barriers in the basalt (fig. 6). The basalt to the south, east, and west dips into the Dalles syn- cline (Piper, 1932). It is covered in many places by several hundred feet of sedimentary beds called the Dalles formation. Numerous faults are known to trend northwestward across the northeastward-plunging syncline; other faults are believed to be present but have not been mapped. A fault or fold escarpment runs south-southeastward through the western part of The Dalles and between the Renken well, 704 feet deep and at an altitude of about 625 feet, in the NW1/4 NE $1 / 4$ sec. 22 ; and the Stark well, 536 feet deep and at an altitude of about 700 feet, in the $\mathrm{NW}^{1} / 4 \mathrm{SW}^{1} / 4 \mathrm{sec} .27$, T. 1 N., R. 13 E. The Stark well, three-quarters of a mile upgradient from this apparent barrier, has a static water level slightly above the land surface. The Renken well, half a mile downgradient from the apparent barrier, has a water level 520 feet below the land surface. The difference of about 600 feet in the water level of these two wells is apparently due to the barrier effects of the intervening fault or sharp fold (fig. 6). Other reservoirs of ground water stored behind structural barriers occur in the Mill Creek and upper Threemile Creek areas near The Dalles.

Ground-water reservoirs that are believed to be due to structural barriers occur in other areas underlain by the basalt, but most of the barriers are too imperfectly known to serve as examples at this time.

Individual wells known to illustrate the effects of barriers in creating ground-water reservoirs of relatively high water-pressure levels are (1) the Marion Cockburn well on Pine Creek, northwest of MiltonFreewater, Oreg., (Newcomb, 1951) ; (2) the Bureau of Reclamation test hole 1 at the Harris Dam site on the South Fork of the Walla Walla River in the NW $1 / 4$ SE $1 / 4$ sec. 12 , T. 4 N., R. 37 E. (G. E. Anderson, written communication); and (3) the flowing well of the city of John Day, Oreg., on the north side of the fault which follows the center of the John Day River valley at that place.

\section{UNDEVELOPED STRUCTURAL RESERVOIRS}

Many untested reservoirs that have been formed by structural barriers should occur in the type conditions present in the mountain areas and on the flanks of uplands. At those places little immediate need exists for additional water for public supply, irrigation, industrial, or other uses, but farther downstream there is urgent need for additional water, especially in the summer and autumn when local supplies are inadequate. Thus, the present utilization of much of this stored ground water may require transporting it in streams, pipelines, or flumes to points of use. Development of these supplies might also be of use in fish culture, power generation, waste disposal, recreation, 
SUBSURFACE DAMS IN COLUMBIA RIVER BASALT

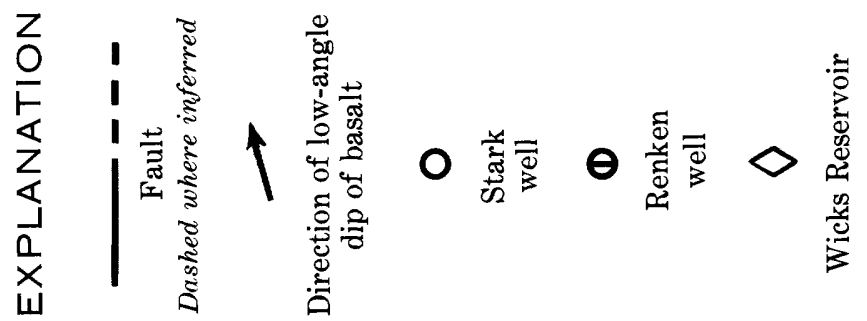
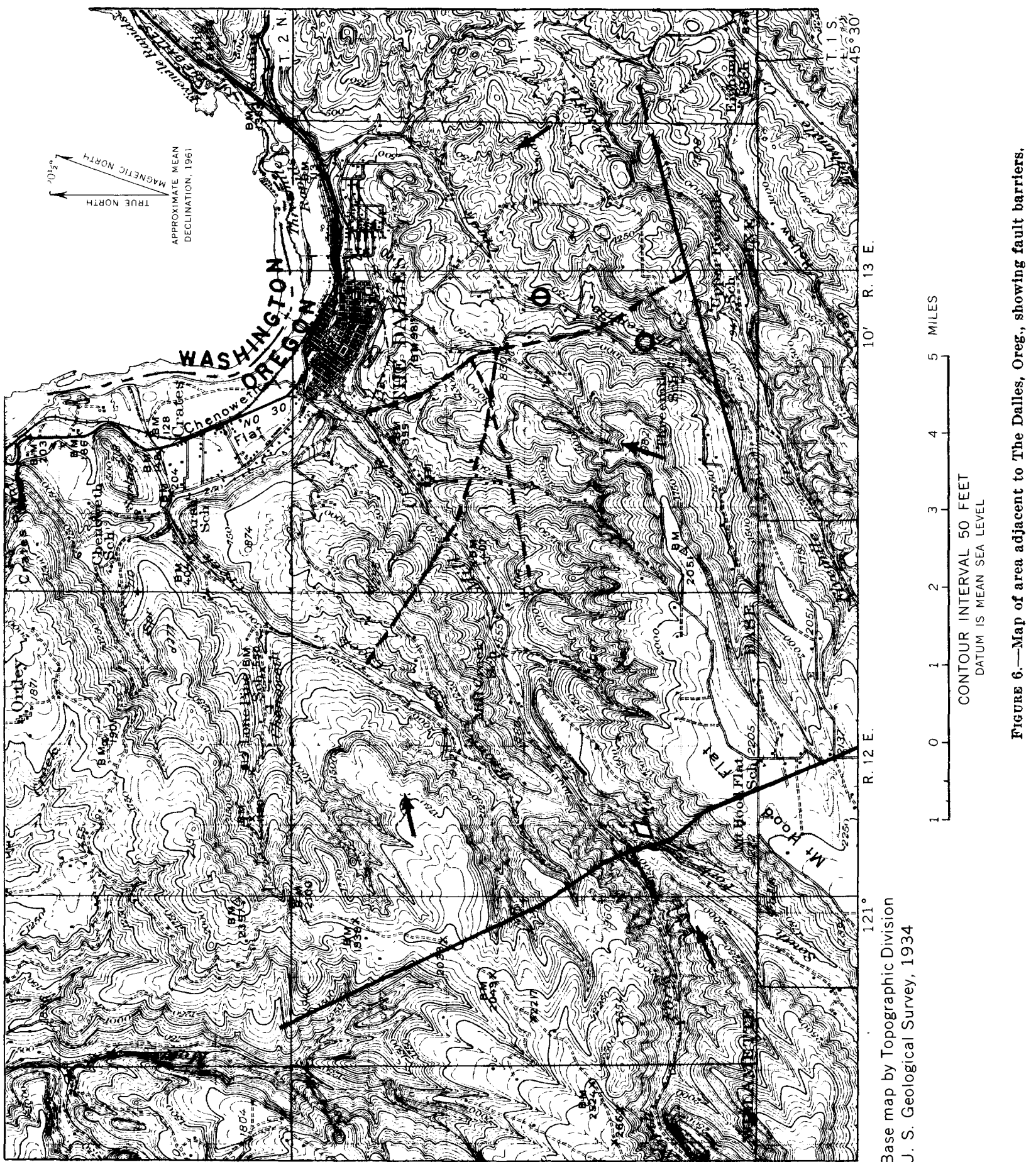

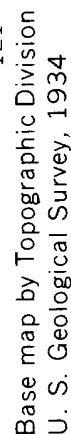


and other activities. The use of the upland reservoirs, as proposed in this paper, is foreseen as a future source of supplemental water to supply some water-short valleys.

\section{SITES PROPOSED FOR TESTING FOR IMPOUNDWP GROUND WATER}

Areas (shown on figs. 1, 6, 7, and 8) in which transverse faults are known to cut the basalt, where it dips on a wide front toward a valley or is warped into a syncline, are present in the valleys of the Walla Walla River, Grande Ronde River, Mill Creek near The Dalles, and John Day River. Some of these areas appear to overlie structural conditions nearly ideal for barirer reservoirs in the basalt. There are many other areas where such reservoirs may occur, but the conditions are not now sufficiently known to warrant testing before further geologic investigations are made.

In the Walla Walla River basin the layered basalt dips generally westward from the crest of the Blue Mountain anticline and extends beneath the alluvial fill which underlies the valley plains. The South Fork, North Fork, Mill Creek, and lesser tributaries flow down the regional slope in deep canyons, and the basalt is cut by several faults which trend generally transverse to the dip of the basalt (fig. 7). The basalt is believed to be at least 500 feet thick beneath the channel bed in most of these canyons. On the basis of the conditions observed in areas of similar geologic structure and on the few well data for this area, the fault zones probably impound ground water in the basalt. "Sites where drilling is considered desirable to test for reservoirs of ground water are (1) along the South Fork, just south of the center of sec. 7, T. 4 N., R. 38 E., upstream from the large fault called the Tom Hite fault; (2) along Mill Creek near the northeast corner of sec. 19, T. 6 N., R. 38 E., upstream from the Kooskooskie fault; and (3) along the South Fork, near the east line of sec. 14, T. 4 N., R. 37 E., upstream from the Elbow Bend fault. These and other likely sites are shown on figure 7.

In the upper part of the Grande Ronde River basin (figs. 1 and 8) the basalt dips southeastward off the Blue Mountain anticline and northwestward from the Elkhorn Ridge to form an elongate synclinal sag, which is followed eastward by the Grande Ronde River from noar Starkey to the valley plain at La Grande (Hampton and Brown, in press). The syncline is cut transversely by northward-trending faults (fig. 8), and some should impound ground water. The following sites considered advisable to test for potential ground- water reservoirs are all upstream from faults: (1) along the Grande Ronde River in the SW1/4 sec. 36, T. 3 S., R. 35 E., (2) in the NE $1 / 4$ sec. 15 , T. 3 S., R. 36 E., and (3) in the $\mathrm{SW}_{1 / 4} \mathrm{SE} 1 / 4$ sec. 31, T. $2 \mathrm{~S}$., R. 37 E.

South and west of The Dalles, Oreg., the strata of basalt and the overlying sedimentary rocks of the Dalles formation dip into a plunging syncline that trends northeast through The Dalles (fig. 6). The basalt in this syncline is broken into blocks by faults, many of which are imperfectly known because they are obscure in the softer materials of the overlying sedimentary rocks. Some of the barrier reservoirs in the basalt have been tapped and partly developed by present wells. A well along the South Fork of Mill Creek, near the N1/4 cor. sec. 33, T. 1 N., R. 12 E., would provide a test of ground-water-reservoir conditions above the strong fault zone that crosses the South Fork near the Wicks Reservoir of The Dalles City Water Department. Other possible barrier reservoirs may be present in that area, but their testing can be deferred until the fault system is known in more detail.

\section{PLAN FOR TEST DEVELOPMENT OF BARRIER RESERVOIRS OF GROUND WATER}

\section{TEST-WELL LOCATION}

The present data for developed barrier reservoirs indicate that it is preferable to drill wells near enough to the fault zones to obtain the maximum hydrostatic pressure, but far enough from them to avoid drilling in the disturbed or shattered rock. The proposed site of each production well should be on the upstream side of the fault zone. The faults of the Walla Walla River basin (fig. 7) and the Mill Creek area (fig. 6) dip steeply downstream; at the Grande Ronde River sites (fig. 8) some faults dip steeply upstream and others dip steeply downstream. In drilling on the upthrown side of a normal fault, the well can be sited reasonably close to the fault (as near as 200 or 300 feet). On the downthrown side of a normal fault, because the fault plane dips toward the well, a greater distance should be allowed-probably at least 300 feet plus a distance equal to the expected depth of the well.

It is proposed that the test wells be located near stream level, so as to gain full advantage of any free artesian flow, and still be adequately sited and equipped with foundations and buttresses to be protected against damage by floodwaters of the stream. Also, the wells will need to be situated to permit the access of mobile drilling equipment. 
SUBSURFACE DAMS IN COLUMBIA RIVER BASALT

삽N
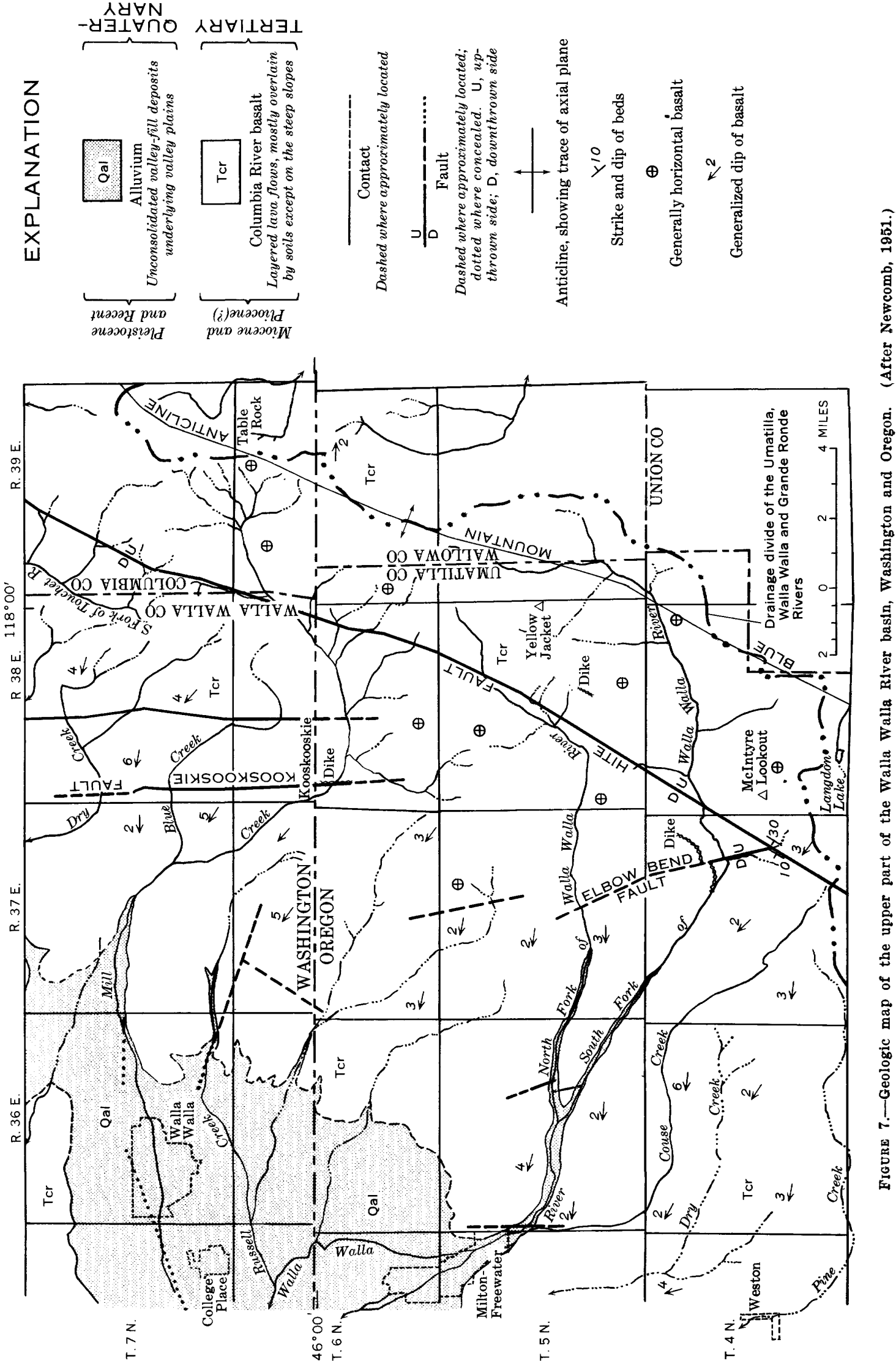


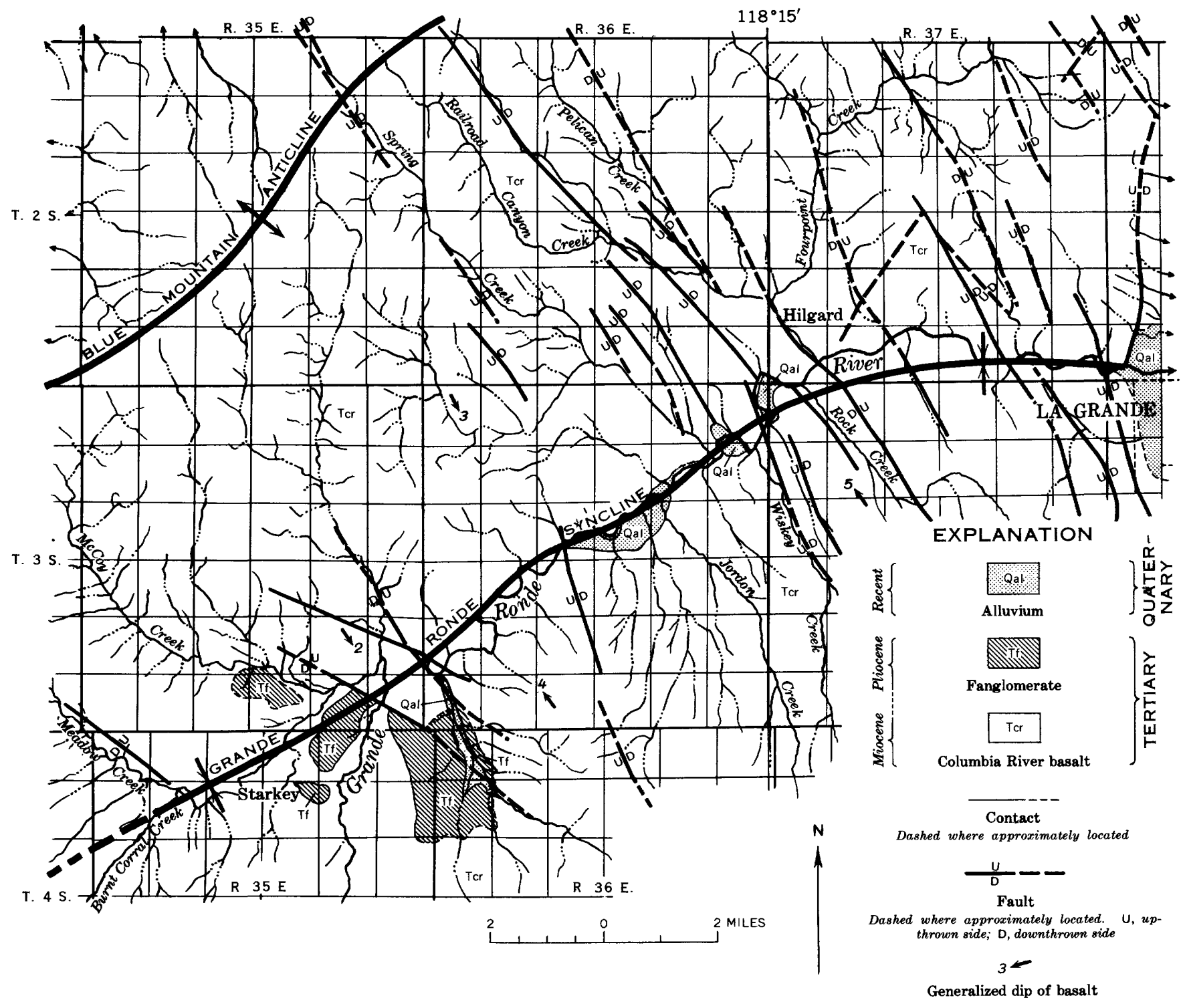

Figcre 8.-Geological map of the Grande Ronde River valley above La Grande, Oreg. (From Hampton and Brown, 19.i9.)

SUGGESTIONS AS TO GENERAL SPECIFICATIONS FOR TEST WELLS

The dip of the layers of the basalt in most of the stream valleys where testing is proposed ranges from $1^{\circ}$ to $5^{\circ}$ and averages $2^{\circ}$ to $3^{\circ}$ downstream, or an average of 200 to 300 feet per mile. This average dip, together with a stream gradient of about 50 to 75 feet per mile, indicates that a 300 -foot well would intercept the permeable zones that crop out in the first mile of the river above the well. Because different hydrostatic pressures probably exist in different aquifers, those of greater depth generally having the higher pressures, it is undesirable for one well to develop water from more than one aquifer or from more than one group of aquifers having similar hydrostatic pressures. Neglect of this precaution may lead to waste of reservoir water through aquifers of lower pressure. Consequently, the pairing of wells, one approximately 300 and one 600 feet deep may be a desirable arrangement for the testing of each barrier reservoir. In places where the basalt is thick and the reservoir is to be fully developed, a third well, about 1,000 feet deep, may be needed during later productive operation (fig. 9).

The proper evaluation of the effect that the use of a ground-water reservoir will have on the nearby stream necessitates gaging the stream. The cost of establishing stream-gaging stations and operating them will be lessened if several nearby wells are served by one station. Also, savings on other surface facilities may be possible by grouping the wells producing water from different depth zones in one barrier reservoir. However, because one well can partly establish the presence 
SUBSURFACE DAMS IN COLUMBIA RIVER BASALT

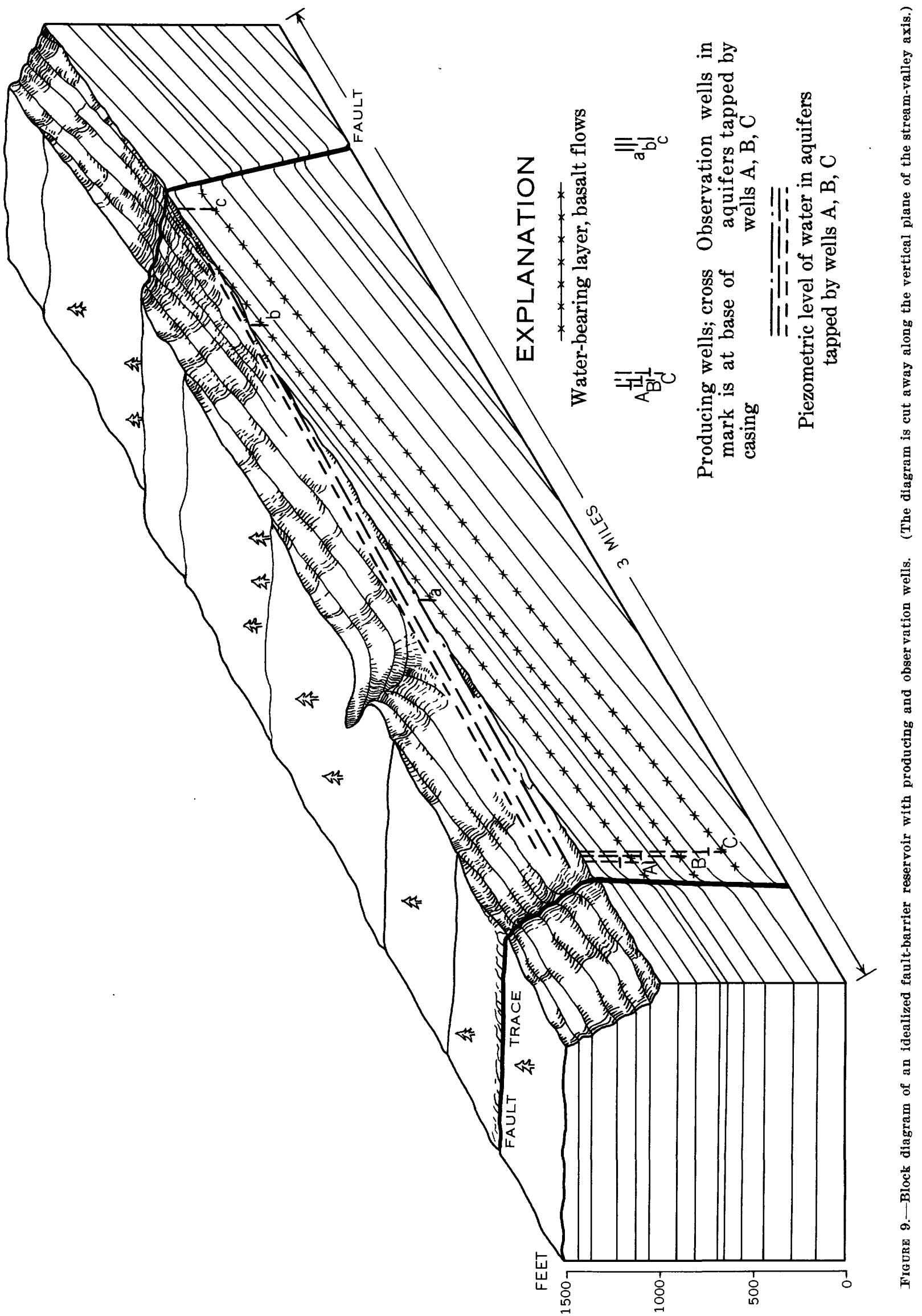


and utility of a reservoir, it is probable that the initial testing of reservoirs will be by means of single wells.

To serve the intended purpose, the wells must be properly cased. As the geologic conditions foreseen in these reservoirs indicate successively greater water pressure with successively greater depth, the sealing of upper aquifers of relatively low pressure head will be necessary in some wells. Some possible arrangements of casing are shown in figure 10. Casing should be equal at least to standard well casing having a minimum wall thickness of 0.33 inch. It should be sealed to the impermeable parts of the rock by grouting with cement. The construction and arrangement of a permanent producing well should be planned to obtain at least a 100 -year use before recasing is necessary.

The surface appurtenances must include proper valve equipment, frost-protection outlets, fireproof protective shelters, and flood-damage protection. Equipment for measuring the flow of the well and the flow of the stream passing the well must be included. Facilities for recording these measurements and keeping the records also must be provided.

At least one observation well is necessary in each reservoir during the test period and after full develop- ment. One 6-inch observation well located upstream from each producing well may be necessary during ultimate full use of a reservoir.

\section{TEST OPERATION OF THE WELLS}

The operation is foreseen as a flow or, if necessary, a pump discharge from the wells in the general period July 1 to November 1 of most years and a period of shut down to allow recovery during the remainder of the year. Records of the discharge of the wells, the temperature of the water, and the flow of the adjacent stream are to be taken during the 4-month period of use. Records of water level, or water-pressure level, in the wells and the discharge of the nearby stream are to be maintained throughout the year. The facts regarding water-level recovery in the aquifers will determine the amount of water that can be extracted from each barrier reservoir and also the rate and timing of the extraction.

The siructural reservoirs suitable for testing include both the type in which the aquifer crops out in the bed of either a permanent or an intermittent stream, and the type in which it does not. The draining of a barrier
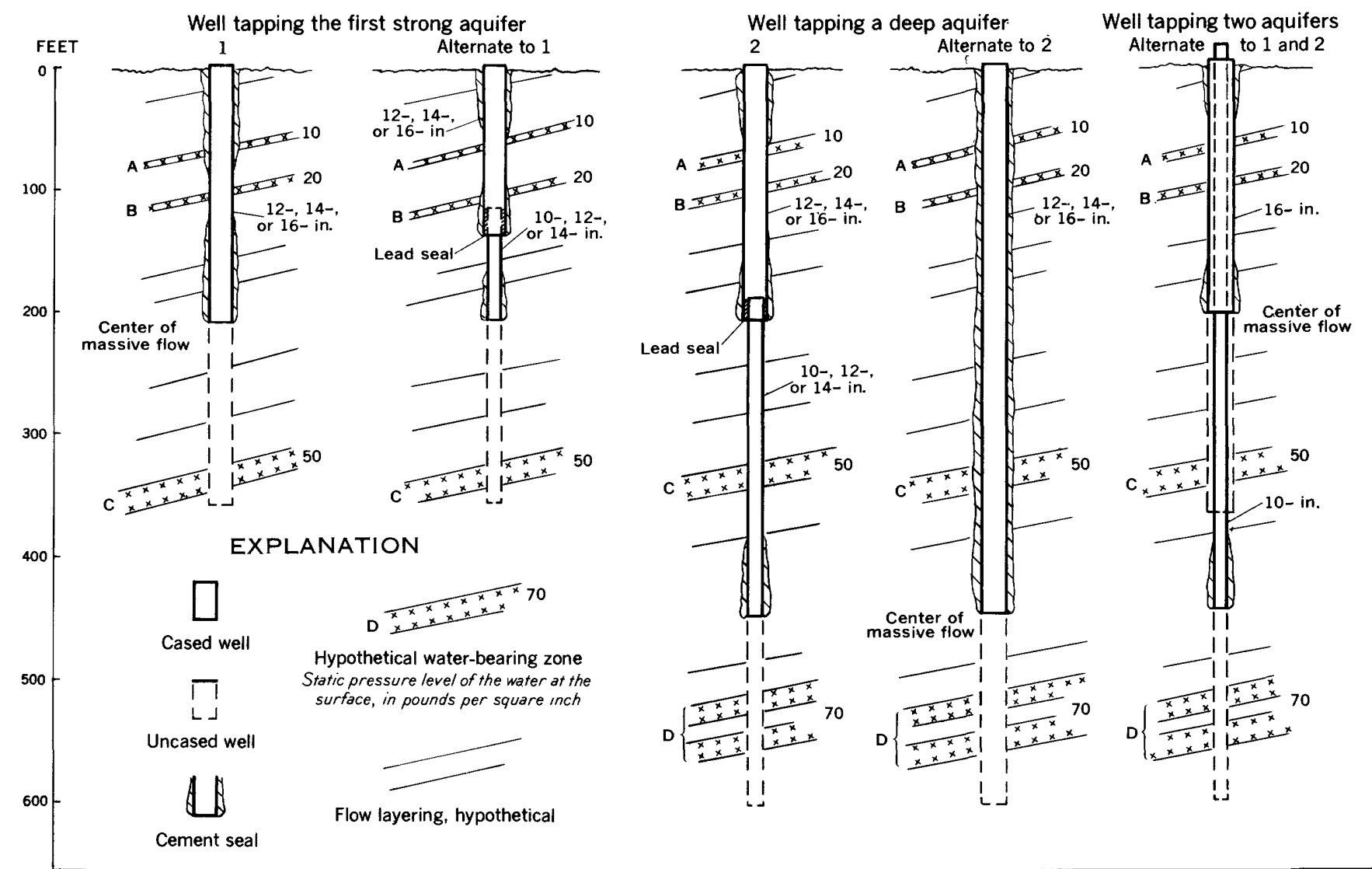

Figure 10.- Schematic diagram of some possible arrangements of casing and wells to tap water stored in a barrier reservọir in basalţ. 
reservoir is expected to induce some recharge as a diversion from any flowing stream that crosses the outcrop of the aquifers. Consequently, the withdrawal of water from storage will be expected to cause some decrease in streamflow downstream from the outcrop of those aquifers. However, the amount of water tapped from storage in the reservoir is expected to be many times the amount of streamflow depletion induced during the period of well operation. The subsequent refilling of the ground-water reservoir, partly by continued seepage from the stream, would occur during the fall and winter runoff period when such diversion from the stream is either beneficial or nondetrimental (fig. 11). It is expected that bedload movement and channel scour will continue the effective infiltration of water at the streambed outcrop of a depleted aquifer.

The possibility of artificial recharge to augment natural infiltration is present but, for brevity, is omitted from this report. Presumably, artificial recharge of clean water could be achieved by pumping water through injection wells during the period of reservoir recovery.

The approximate amount of streamflow depletion during the period of well use can be calculated, for idealized conditions, by the use of the Theis nonequilibrium equation (Theis, 1935). The effect of the barrier on the lowering of the water level at both the pumped well and the outcrop of the aquifer is computed from that equation and adjustments derived from the laws governing the drawdown of the water level in image wells (Ferris, 1949).

Under the assumed conditions of a producing-well system such as is shown in figure 12 , and on the basis of conservative coefficients of transmissibility and storage, a withdrawal of $1,000 \mathrm{gpm}$ for 120 days would result in a drawdown $\circ f$ about 140 feet at the producing well and of 50 feet at the outcrop of the aquifer. In these calculations the coefficient of transmissibility was assumed to be 25,000 gallons per day per foot and the coefficient of storage to be $0.0001 .^{1}$

If there is 50 feet of drawdown at the outcrop of the aquifer, the ground-water surface would have a generally downstream gradient of 20 feet per mile by the end of 120 days. Theoretically, this drawdown at the outcrop should induce infiltration ranging from 10 $\mathrm{gpm}$ at the beginning of the pumping season to 250 $\mathrm{gpm}$ at its end. Because the calculated 140 feet of drawdown exceeds the 100 feet of hydrostatic pressure

\footnotetext{
1 The coefficient of transmissibility is defined as the number of gallons of water that will pass in 1 day, under prevailing conditions, through a vertical strip 1 foot wide extending the height of the aquifer under a hydraulic gradient of 1 foot in 1 foot. The coefficient of storage of an aquifer is the volume of water it releases from or takes into storage per unit surface area of the aquifer per unit change in the component of head normal to that surface.
}

at the beginning of the test, this well would need to be pumped near the end of the season or the flow be reduced to a seasonal average of about $700 \mathrm{gpm}$. So many unknowns and assumptions based on scant data are included in these calculations that their only significance is that they show general quantitative agreement with the results estimated from a qualitative approach.

\section{ESTIMATED COST OF A PROPOSED TEST INSTALLA- TION AND TEST PROCEDURE}

The necessary test wells should include both shallow and deep wells, both of which are foreseen as the ultimate outlets of water from barrier reservoirs.

Assuming that each reservoir will ultimately be developed by at least one well 300 to 400 feet deep paired with a well 600 to 700 feet deep, the depth of 4 test wells is estimated to total 2,000 feet. When completed with proper casing and sealing, each of these wells, of $14-, 12-$, and 10-inch diameter, may cost about $\$ 25$ per foot. Valves, meters, aeration trays (for absorption of oxygen, where needed), and other appurtenances are estimated to cost $\$ 2,000$ per well. Observation wells of 8- to 4-inch diameter located about midway between producing wells and the outcrop of the aquifer should be plamned near 2 of the 4 well sites. Each would cost about one-fourth as much as a producing well.

A station for accurate gaging of the nearby stream is estimated to cost an average of $\$ 5,000$, which includes the cost of the installation and the first year's operation. Such a gaging station would serve one barrier-reservoir installation, whether single, twin, or triple wells are used, but even if only one test well is drilled at each barrier tested, the cost of one stream-gaging station will need to be included in the cost of development for each barrier reservoir.

On the basis of 1959 prices, the estimated cost of testing four barrier reservoirs with single producing wells is :

Drilling casing, and completing 4 wells, total length 2,000 feet, at $\$ 25$ per foot_..._-_.-- $\$ 50,000$

Appurtenances -

Observation wells, 4_._- 12,000

Stream-gaging station (including cost of first year of test), 4

Total $\$ 90,000$

Thus, the cost of testing 1 barrier reservoir on a singlewell basis would be about $\$ 22,500$.

The estimated annual operating cost at 1 test reservoir thereafter is about $\$ 1,000$, on the assumption that the operation would be under the supervision of a county watermaster or similar official. It is assumed that most of the cost is that of gathering the hydraulic data, and at any reservoir this cost would be about the same, 

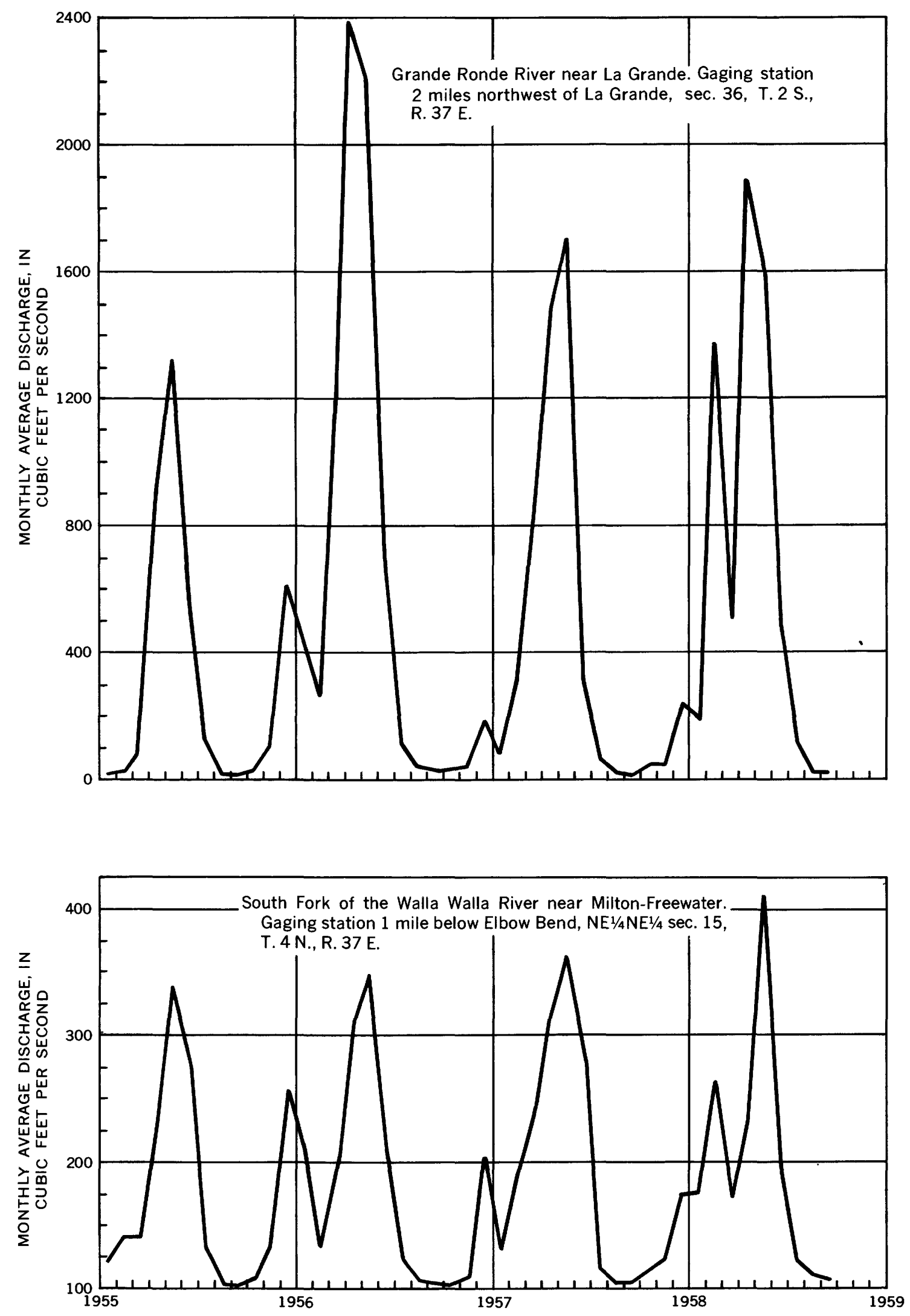

FIGURE 11.-Average monthly discharge in two rivers where structural reservoirs of ground water are believed present for artificially augmenting the annual low flow. 


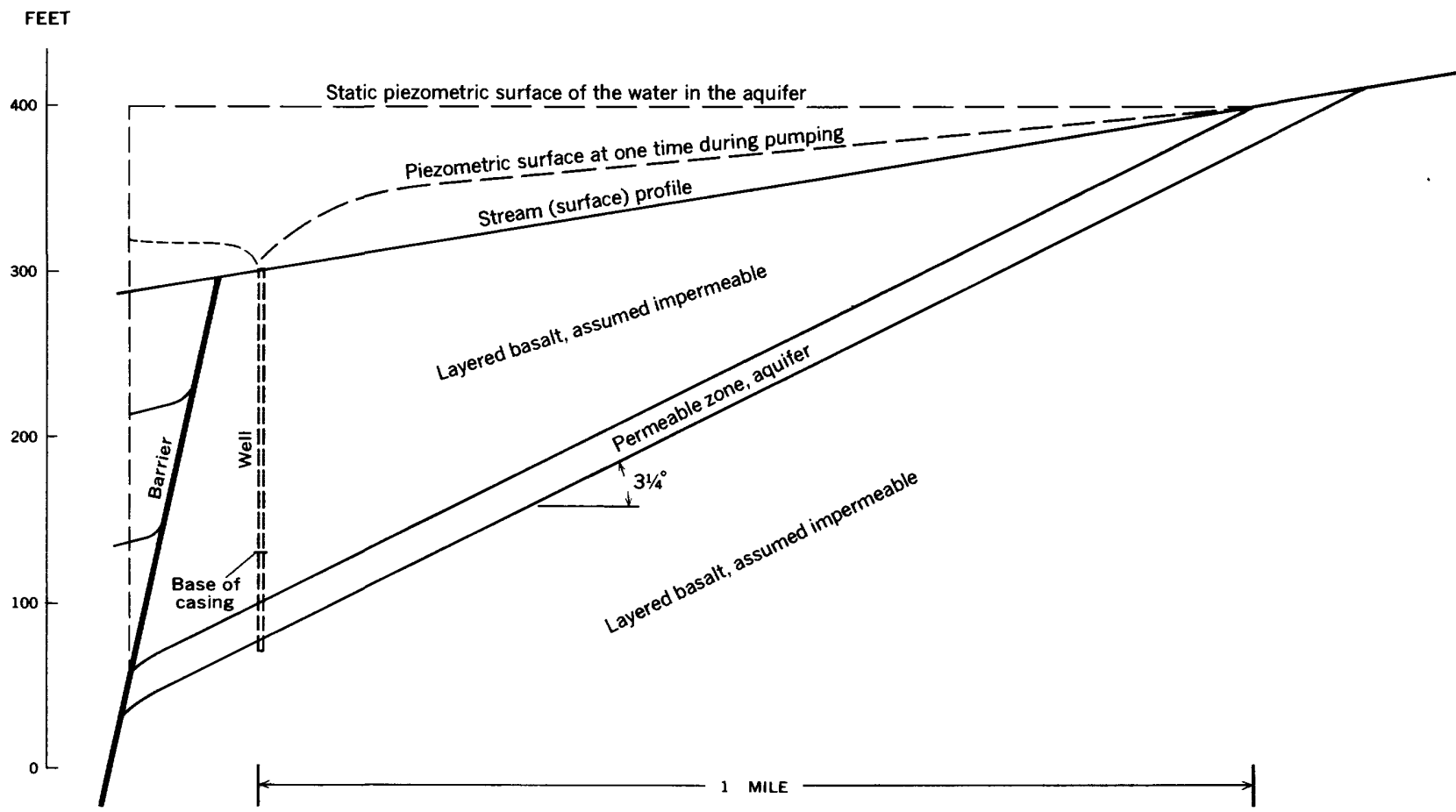

FEET

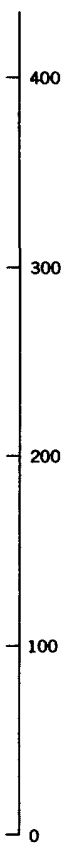

FIgure 12.-Cross section of a hypothetical ground-water-withdrawal system utilizing an aquifer of a barrier reservoir.

regardless of the number of wells used. Thus, ultimate full production at each reservoir may not entail an average operational cost of much over $\$ 1,000$ per year.

In these estimates the cost of pumping is omitted, because one objective in the location of the test sites would be to secure free-flowing wells where pumping costs would be avoided.

\section{VALUE OF THE BENEFITS DERIVED}

By continuing a hypothetical average well yield of $1,000 \mathrm{gpm}$ over 120 days and assuming that 80 percent is new water previously unavailable, a total of 425 acre-feet of new water would be made available by each well. At $\$ 8$ per acre-foot, the value of this water for irrigation purposes would be about $\$ 3,400$ per year.

At some sites, where a hydroelectric plant would use the water at 200 feet gross head, this 1.75 cubic feet per second of new water in 120 days of the low-flow period would generate 67,000 kilowatt hours of electricity, which, at $\$ 0.007$ per kilowatt hour, would have a value of $\$ 470$ per year.

It is difficult to compute the value of the new water for fish culture, especially for the improvement of otherwise good spawning reaches that lack an adequate summer flow, as does the Grande Ronde River between Starkey and La Grande, Oreg. The value of the new water for such uses as recreation, public and domestic supply, abatement of pollution, and watering of livestock is also difficult to assess at this time.

These conservative estimates show that the wells would yield new water that annually would exceed in value the operating costs and at least 5 to 10 percent of the capital investment.

\section{REFERENCES CITED}

Ferris, J. G., 1949, Ground water, in Wisler, C. O., and Brater, E. F., Hydrology : New York, John Wiley and Sons, p. 198-272, figs. 62-98.

Hampton, E. R., and Brown, S. G., 1959, Geology and groundwater resources of the Upper Grande Ronde River basin, Union County, Oreg. : U.S. Geol. Survey open-file report.

Hart, D. H., 1958, Tests of artesian wells in the Cold Creek area, Washington: U.S. Geol. Survey open-file report.

Newcomb, R. C., 1951, Preliminary report on the ground-water resources of the Walla Walla basin, Washington-Oregon: U.S. Geol. Survey open-file report. 1959, Some preliminary notes on ground water in the Columbia River basalt: Northwest Sei., v. 33, no. 1, p. 1-18.

Piper, A. M., 1932, Geology and ground-water resources of The Dalles region, Oregon: U.S. Geol. Survey Water-Supply Paper 659-B, p. 107-189, pls. 11-19.

Theis, C. V., 1935, The relation between the lowering of the piezometric surface and the rate and duration of discharge from a well using ground-water storage: Am. Geophys. Union Trans., pt. 2, p. 519-524. 


\section{Geologic Factors That}

Control the Occurrence and

Availability of Ground Water

in the Fort Rock Basin

Lake County, Oregon

By E. R. HAMPTON

HYDROLOGY OF VOLCANIC-ROCK TERRANES

GEOLOGICAL SURVEY PROFESIONAL PAPER $383-$ B

Prepared in cooperation with the

Oregon State Engineer

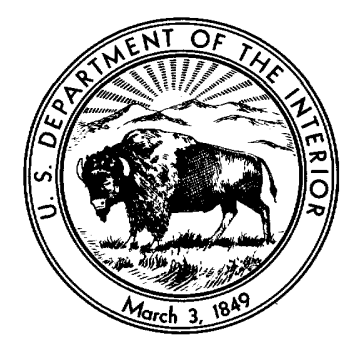

UNITED STATES GOVERNMENT PRINTING OFFICE, WASHINGTON : 1964 
UNITED STATES DEPARTMENT OF THE INTERIOR

\section{STEWART L. UDALL, Secretary}

GEOLOGICAL SURVEY

Thomas B. Nolan, Director

The U.S. Geological Survey Library has cataloged this publication as follows:

\section{Hampton, Eugene R., 1934-}

Geologic factors that control the occurrence and availability of ground water in the Fort Rock Basin, Lake County, Oregon. Washington, U.S. Govt. Print. Off., 1964.

iii, 29 p. illus., maps ( 1 fold. col. in pocket) diagrs., tables. $30 \mathrm{~cm}$. (U.S. Geological Survey. Professional paper 383-B)

Hydrology of volcanic-rock terranes.

Prepared in cooperation with the Oregon State Engineer.

Bibliography : p. 29.

(Continued on next card)

Hampton, Eugene R., 1934-

Geologic

factors that control the occurrence and availability of ground water in the Fort Rock Basin, Lake County, Oregon. 1964. (Card 2)

1. Geology-Oregon-Lake Co. 2. Water-supply-O re g o n-Lake Co. 3. Water, Underground-Oregon-Lake Co. 4. Borings-Oregon-Lake Co. I. Oregon. State Engineer. II. Title. III. Title: Fort Rock Basin, Lake County, Oregon. (Series)

For sale by the Superintendent of Documents, U.S. Government Printing Office Washington, D.C. 20402 


\section{CONTENTS}

Abstract

Introduction.

Location and extent of the area.

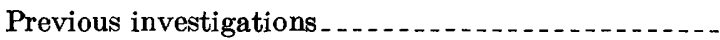

Acknowledgments.....

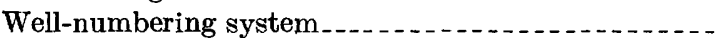

Geography

Climate

Culture and industry

Landforms and drainage

Basin floor

Mountain uplands . .

Geology

General description and relationship of rock units

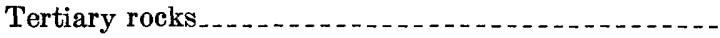

Picture Rock Basalt

Volcanic rocks of intermediate composition...-.

Fort Rock Formation . . . . . .

Hayes Butte Basalt. ... . . . . . . . . . . . .

Tertiary and Quaternary rocks. . .

Peyerl Tuff . . . . . . . . . .

Paulina Basalt.

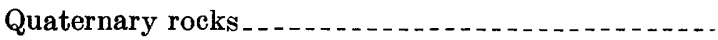

Unconsolidated deposits . . . . .

Lakebed and terrace deposits_.

\begin{tabular}{|c|c|c|}
\hline Page & Geology-Continued & Page \\
\hline B1 & Quaternary rocks-Continued & \\
\hline 1 & Unconsolidated deposits-Continued & \\
\hline 1 & Delta deposits & B15 \\
\hline 2 & Dune sand & 15 \\
\hline 2 & Stream-valley alluvium & 16 \\
\hline 3 & Younger basalt & 16 \\
\hline 3 & Geologic structure & 16 \\
\hline 3 & Folds & 16 \\
\hline 3 & Faults__. & 17 \\
\hline 4 & Ground water & 17 \\
\hline 4 & Infiltration and recharge & 17 \\
\hline 4 & Discharge & 18 \\
\hline 4 & Water-level fluctuations & 18 \\
\hline 5 & Chemical quality of the ground water & 18 \\
\hline 5 & Occurrence in subareas of the Fort Rock Basin & 19 \\
\hline 5 & Hager Mountain slops & 20 \\
\hline 5 & Paulina Marsh subarea & 21 \\
\hline 7 & Thorne Lake subarea & 21 \\
\hline 7 & Seven Mile Ridge subarea & 22 \\
\hline 11 & Lost Forest subarea & 22 \\
\hline 12 & Fort Rock-Christmas Lake Valleys & 22 \\
\hline 12 & Hayes Butte slope & 23 \\
\hline 14 & Horse Ranch subarea & 23 \\
\hline 14 & Potential for additional development & 23 \\
\hline 14 & Well construction. & 24 \\
\hline 14 & Referencess. & 29 \\
\hline
\end{tabular}

\section{ILLUSTRATIONS}

[Plate is in pocket]

Plate 1. Geologic map and sections of the Fort Rock Basin, Lake County, showing location of selected wells.

FIgURE 1. Map of Oregon showing the area of this investigation

2. Map of the Fort Rock Basin, Lake County, showing general features in the area studied.

3. Horning Bend and Hayes Butte as seen from the southwest

4. Stratigraphic column showing the relationships of the rock units mapped in the Fort Rock Basin.

5. Rhyodacite on the west side of Cougar Mountain

6. Bedded tuff of the Fort Rock Formation

7. Fort Rock viewed from the northeast

8. Annual precipitation and cumulative departure from the average precipitation at Fremont for the period 1910-59 and hydrograph of year-end water levels in well $27 / 15-4 \mathrm{G} 1$

9. Map of the Fort Rock Basin showing principal ground-water subareas

10. Map of the Fort Rock Basin showing areas irrigated from wells in 1960

\section{TABLES}

Table 1. Drillers' logs of selected wells in the Fort Rock Basin, Lake County, Oreg

2. Chemical analyses of water from wells in the Fort Rock Basin, Lake County, Oreg 

HYDROLOGY OF VOLCANIC-ROCK TERRANES

\title{
GEOLOGIC FAGTORS THAT GONTROL THE OCGURRENGE AND AVAILABILITY OF GROUND WATER IN THE FORT ROGK BASIN, LAKE COUNTY, OREGON
}

\author{
By E. R. HaMptoN
}

\begin{abstract}
The Fort Rock Basin, in south-central Oregon, is a high plateau area of interior drainage comprising about 1,500 square miles. The precipitation is sparse-less than 10 inches per year on the basin floor-and the growing season is less than 100 days. Consequently, the ready availability of ample water for irrigation is a requisite for successful farming in the area.

Three perennial streams enter the southwestern part of the basin and provide water for irrigation and stock supplies for that part of the basin. In the rest of the basin, water for irrigation, stock, and domestic supplies is obtained from wells.

Geologic structural features, consisting mainly of broad, gentle folds and predominantly northward-trending faults, largely control the depth and areal distribution of the water-bearing rock units. Thus, the availability of ground water in any particular part of the basin is directly related to the geologic structure and the rock units present.

The rock units mapped in the basin range in age from Pliocene to Recent and are from oldest to youngest as follows: Picture Rock Basalt, volcanic rocks of intermediate composition, Fort Rock Formation, Hayes Butte Basalt, Peyerl Tuff, Paulina Basalt, unconsolidated deposits, and younger basalt. of these units, the volcanic rocks of intermediate composition, Peyerl Tuff, and young basalt yield little or no water to wells; the other units yield small to large quantities of ground water where they are saturated. Yields as great as 4,000 gallons per minute are obtained from wells tapping the Picture Rock Basalt.

The more productive aquifers yield water of good quality, but a few wells tapping poorly productive zones in the Fort Rock Formation yield moderately saline water. Pumpage in 1960 was about 12,000 acre-feet-about one-tenth the estimated average annual recharge of 125,000 acre-feet.

Long-term water-level fluctuations lag about 10 years behind the recorded long-term precipitation fluctuations. This fact indicates that most of the ground-water recharge occurs on the sloping flanks of the basin and that the water requires years to move to the areas of discharge in the central part of the basin or to adjacent lower basins. Pumping withdrawals apparently do not materially affect the long-term fluctuations; this lack of influence indicates that considerable additional ground water is available for irrigation and other uses.
\end{abstract}

\section{INTRODUCTION}

\section{PURPOSE AND SCOPE OF THE INVESTIGATION}

The Fort Rock Basin, in northern Lake County, Oreg., consists of high desert plains and the mountain slopes that surround them. Some hay and grain crops are raised near the edges of the valley plains, although the climate is cool and dry and the growing season short. The dry climate and short growing season make irrigation necessary for the production of economic yields of most crops. Surface water is available for irrigation only in the Silver Lake area. In other parts of the basin irrigation water must be obtained from wells.

About 100 irrigation wells were being used in the area during 1960 and additional wells were being drilled. The lack of information on the rock materials underlying the basin has hampered prediction of the well-drilling conditions and the water-bearing character of the rocks at any locality, although the position of the water table is fairly well known. Thus most wells, being largely exploratory, have been unduly costly and a considerable number have been unsuccessful, either because of improper well construction or because permeable water-bearing rocks were not present.

The objectives of this investigation are: (1) to obtain information on the extent, structure, and waterbearing characteristics of the rock units underlying the area, (2) to determine the control of these geologic factors on the occurrence, availability, and chemical quality of the ground water for the area as a whole and for specific subareas, (3) to make these data available to persons concerned with development or management of the ground-water resources of this and similar upland basins.

This study was made by the Geological Survey in financial cooperation with the Oregon State Engineer. The fieldwork was done under the direction of $\mathbf{R}$. C. Newcomb, former district geologist in charge of ground-water investigations in Oregon; this report was prepared under the direction of B. L. Foxworthy, who succeeded Mr. Newcomb. Reconnaissance and detailed reconnaissance-geologic mapping was done intermittently during the summer and fall months of 1956-58 
by G. M. Hogenson. Similar work was done by the author during September 1958 and the latter part of April 1959. The geology was mapped on aerial photographs, if available, and transferred to planimetric maps. Records of wells were obtained from drillers' and owners' reports to the Oregon State Engineer, from field inventory, and from data previously compiled by Trauger (1950).

\section{LOCATION AND EXTENT OF THE AREA}

The Fort Rock Basin is in northern Lake County in central Oregon (fig. 1). It is a topographic basin of interior drainage that includes the high plains commonly known as the Silver Lake-Thorne Lake Valley, Christmas Lake Valley, Fort Rock Valley and slopes adjacent to those plains (fig. 2). The basin is about 1,500 square miles in area, about 50 miles long (eastwest), and about 30 miles wide.

\section{PREVIOUS INVESTIGATIONS}

Early investigations of the general geology of south central Oregon were made by Russell (1884, p. 431464) and Waring (1908). Waring's report included a generalized geologic map that covered much of Lake County including the Fort Rock Basin, and a reconnaissance topographic map of the area.

The only previous hydrologic study describing this area was made by Trauger (1950). His work included the collection and compilation of records of wells, springs, ground-water levels, and chemical quality of ground water and the compilation of a reconnaissance geologic map of Lake County.

Previous investigations of areas adjacent to the Fort Rock Basin include a study of the geology and groundwater conditions of the Klamath River basin (southeast of this area) by Newcomb and Hart (1958), a brief discussion of the geology of the Glass Buttes (about 30

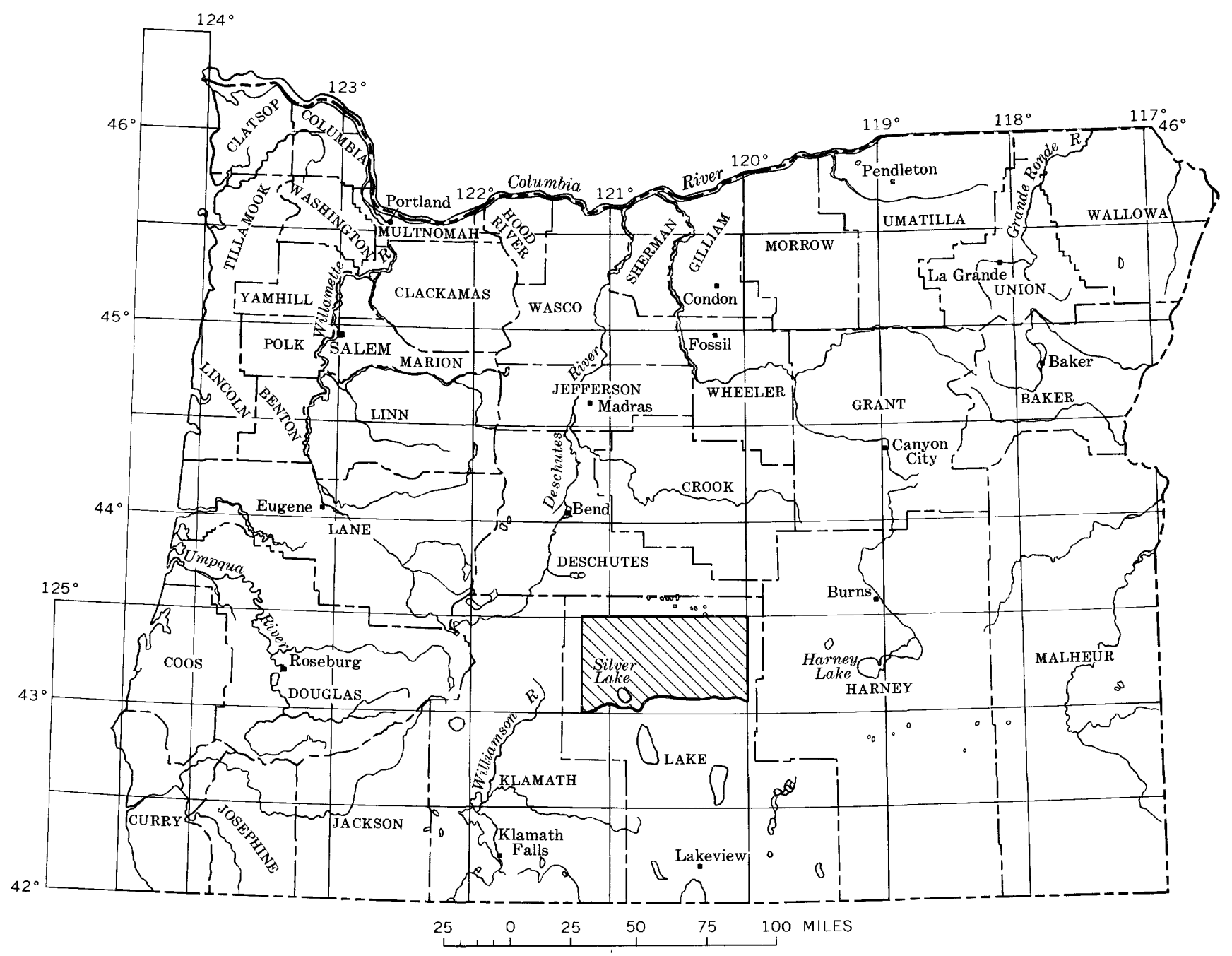

Figure 1.-Map of Oregon showing the area of this investigation. 


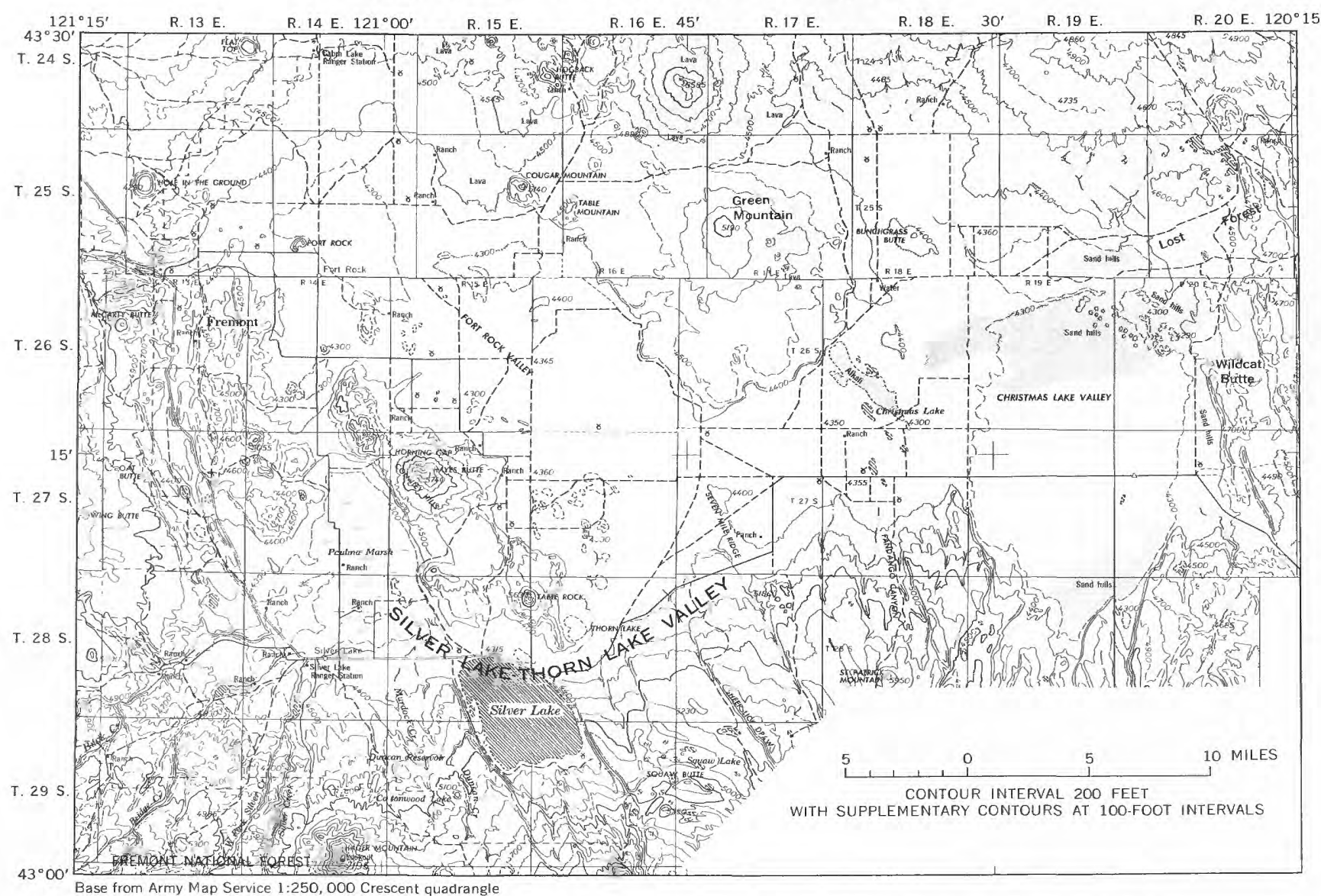

Figdre 2.-Map of the Fort Rock Basin, Lake County, Oreg., showing general features in the area studied.

miles northeast of the Fort Rock Basin) by Waters (1927), and a detailed description of the Newberry Volcano (about 30 miles northwest of Fort Rock) by Williams (1935).

\section{ACKNOWLEDGMENTS}

The U.S. Soil Conservation Service office in Silver Lake, Oreg., supplied many of the aerial photographs used to aid field mapping. Base maps of the area were furnished by the U.S. Forest Service and the Oregon State Highway Department.

\section{WELL-NUIMBERING SYSTEM}

Wells discussed in this report are designated by symbols that indicate their location according to the rectangular system of land division. In the symbol 29/13$3 \mathrm{G} 1$, for example, the part preceding the hyphen indicates the township and range (T. 29 S., R. 13 E.) south and east of the Willamette base line and meridian. As shown in the diagram (at right), the first number after the hyphen indicates the section (sec. 3) and the letter $(G)$ indicates a 40-acre subdivision of the section. The final digit is the serial number of the well within that 40 -acre tract. Thus, well 29/13-3G1 is in SW $1 / 4$ NE $1 / 4$ sec. 3, T. 29 S., R. 13 E., and is the first well in the tract to be listed.

\section{GEOGRAPHY}

\section{CLIMATE}

The basin has an arid climate and receives on the average less than 10 inches precipitation annually (fig. 8). Because of the high altitude, early morning frost can be expected during any month of the year, and the average growing season is a little less than 100 days.

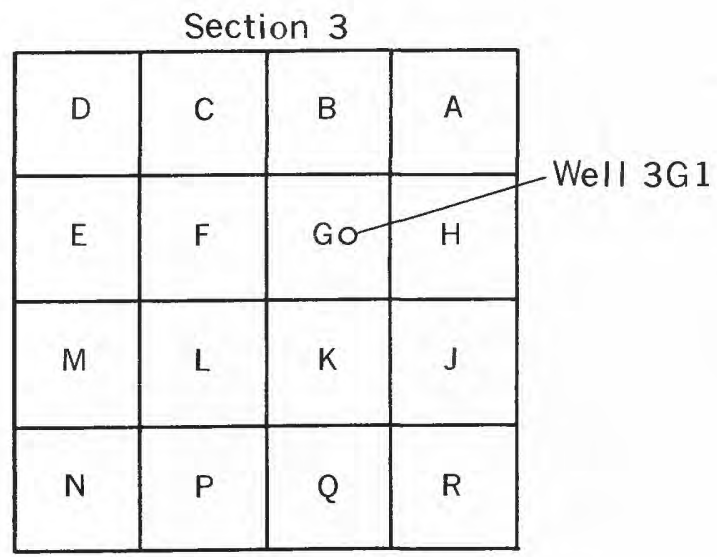




\section{CULTURE AND INDUSTRY}

About 300 people live within the area. The only centers of population are the hamlets of Silver Lake and Fort Rock.

The area is served by State Highway 31, which traverses its western and southern border, as well as by many roads and trails that are passable except during the wettest or snowiest times of the year. Throughout most of the year the mountainous areas that border the basin are accessible via narrow, rocky jeep trails.

Larger commercial centers nearest the basin are Bend and Lakeview, 70 miles northwest of and about 75 miles southeast of the town of Silver Lake, respectively.

Agriculture is the main occupation in the Fort Rock Basin, and the principal products of the area are livestock, small grains, and hay. Some pine timber from the mountains south of Silver Lake is sawed at mills at Silver Lake and at Klamath Falls, about 75 miles southwest of Silver Lake. The tourist industry is also an important source of income for the people of the small commercial centers of Silver Lake and Fort Rock.

\section{LANDFORMS AND DRAINAGE}

The Fort Rock Basin and adjacent upland areas are within the Great Basin section of the Basin and Range physiographic province (Fenneman, 1931, p. 326-395). Physiographic features typical of the northern Great Basin, as well as transition features associated with the Columbia Plateaus physiographic province, are represented within the area.

The landforms of the Fort Rock Basin fall in two categories-those associated with the basin floor and those associated with the mountain uplands. The basin floor has an altitude of about 4,300 feet, and the moun- tainous parts of the drainage basin that are included within this report rise to altitudes exceeding 5,900 feet; thus the maximum relief within the area is about 1,600 feet. The drainage of the basin is internal, and only three of the streams-Buck, Silver, and Bridge Creeksare perennial. The channels of the other creeks in the uplands are dry most of each year.

\section{BASIN FLOOR}

Topographic features on the plains of the basin are the result of four main processes-water deposition, wave action, wind action, and volcanism. The volcanic features are the most apparent because the local relief due to water, wave, and wind action rarely exceeds 50 feet. In contrast, eroded cinder cones and volcanic plugs rise as much as 200 feet above the general basin floor; these and smaller spatter cones dot the area near Fort Rock.

\section{MOUNTAIN UPLANDS}

The most striking topographic features of the mountain uplands that surround the basin are high fault scarps, block mountains, volcanic shields and cones, and slopes and surface features of the lava. Some examples of block mountains and fault scarps, features typical of the Great Basin type of physiography, occur along the southern border of the basin in the mountains that separate this basin from the adjacent Summer Lake basin to the south and along both the eastern and western borders of the basin. Gently sloping lava plains and lava shields, as well as cinder and lava cones, form the uplands to the north and west of the basin. The Connley Hills formed by Horning Bend and Hayes Butte, which are respectively an eroded lava cone and a composite lava shield, rise in the south-central part of the basin (fig. 3).

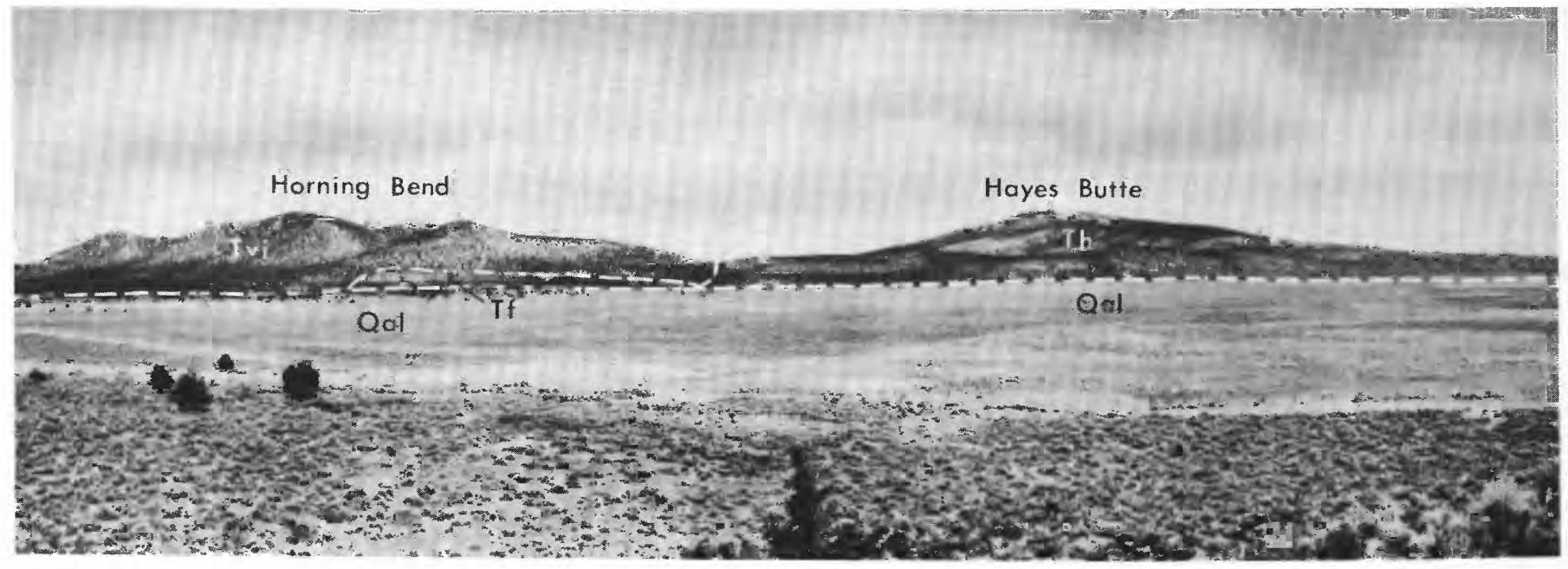

Frgure 3.-Horning Bend and Hayes Butte as seen from the southwest. Dashed lines mark the approximate limits of the volcanic rocks of intermediate composition (Tvi), Fort Rock Formation (Tf), Hayes Butte Basalt (Th), and unconsolidated deposits (Qal). 


\section{GEOLOGY \\ GENERAL DESCRIPTION AND RELATIONSHIP OF ROCK UNITS}

The rock units of the Fort Rock Basin range in age from Pliocene to Recent and, from oldest to youngest, are: Picture Rock Basalt, volcanic rocks of intermediate composition, Fort Rock Formation, Hayes Butte Basalt, Peyerl Tuff, Paulina Basalt, unconsolidated deposits, and younger basalt.

Some of these rock units intertongue and are in part equivalent in age, but are readily distinguishable on the basis of lithology. The intertonguing relationships are due mainly to the deposition of the volcanic and pyroclastic rocks from different centers of eruption or extrusion during overlapping periods of time. The general stratigraphic relationships of the units mapped in the area are shown in figure 4 . The extent and relative positions of these units are shown on the geologic map and sections (pl. 1).

\section{TERTIARY ROCKS}

\section{PICTURE ROCK BASALT}

The oldest rock unit exposed in the area is a thick sequence of basaltic lava flows and interbedded pyroclastic materials herein named the Picture Rock Basalt. The unit is named for Picture Rock Pass, the pass between the Fort Rock and Summer Lake basins, where a great thickness of flows typical of the unit are exposed. An exposure in secs. 14 and 15, T. 29 S., R. 16 $\mathrm{E}$., is hereby designated the type section. However, because not all the rock types found in this unit occur in this exposure, a second exposure in a fault scarp, about 6 miles south of Buffalo Wells, in sec. 8, T. $28 \mathrm{~S}$., R. 20 E., is designated a reference section for this unit.

The Picture Rock Basalt underlies more than 150 square miles in the southern part of the mapped area (pl. 1). Layers of this basalt form the rather gentle plateau slopes and the abrupt escarpments of the uplands south and east of Silver Lake. Some excellent exposures of these rocks are in the scarps adjacent to Silver Lake. The Picture Rock Basalt also underlies large tracts south and east of the mapped area but has not been differentiated from other basaltic lavas in those tracts. Basalts of similar lithology of roughly equivalent age underlie vast areas of south-central Oregon. As yet, however, there is insufficient information to allow correlation of these similar basalts between the fault-bound basins in which they occur.

In contrast to younger lavas in the area, which generally have retained some of their initial surficial roughness, the surface of the Picture Rock Basalt forms uni-

\section{AGE ROCK UNIT}

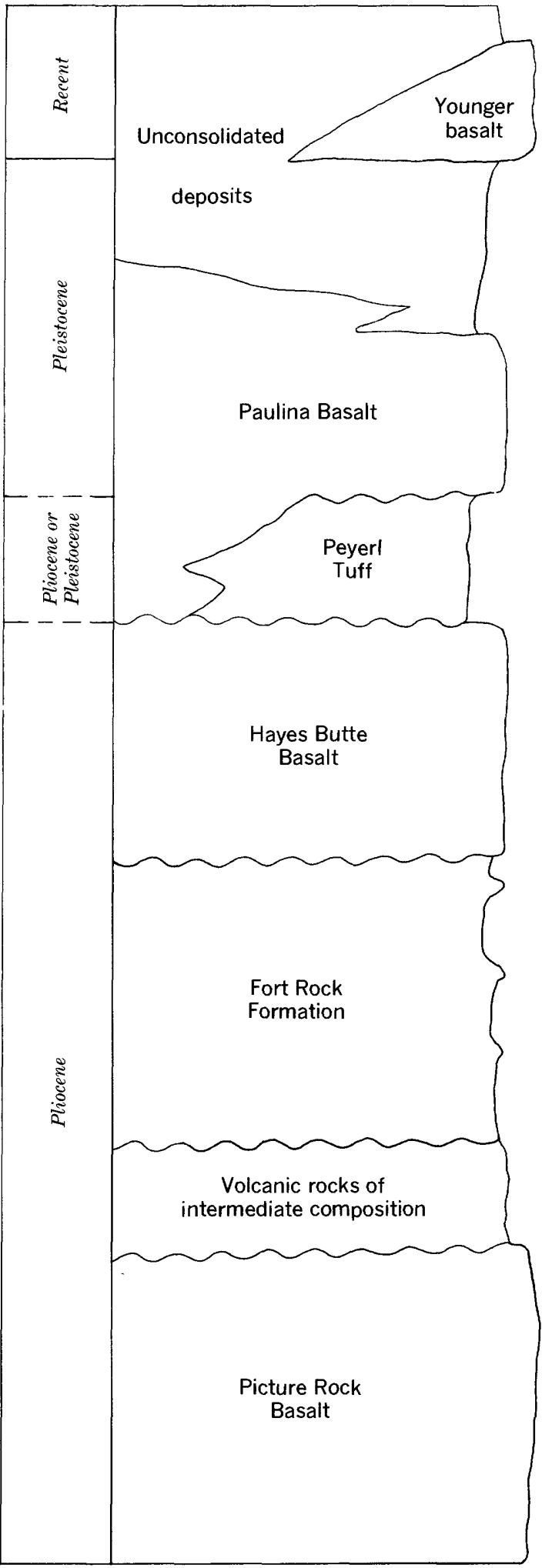

FigURE 4.- Stratigraphic column showing the relationships of the rock units mapped in the Fort Rock Basin. 
form and rather smooth slopes. A mantle of weathered basalt boulders, which average about 12 inches in diameter, is mixed with the thin soils derived from the Picture Rock Basalt. The soil developed on the basalt is very thin and rocky and is not suited for tillage.

The bottoms of most flows of the Picture Rock Basalt are somewhat scoriaceous, brecciated, and glassy. This thin basal zone may be permeable and may transmit water. The middle parts of the flows are massive and usually have very few vesicles or open cracks and joints. Some of the joint blocks of lava in the middle parts of the flows are as much as 5 feet in diameter. At most places, the upper parts of the flows are vesicular but relatively unbroken or are cindery and brecciated; thus they appear to be rather permeable. Because most flows are relatively thin $(10-50 \mathrm{ft})$, the vesicular and cindery zones constitute a rather large part of their thickness. These zones, as well as the contraction joints, impart an overall fractured, pervious appearance to most exposures of the unit.

The basalt is dark gray, blue gray, or dark green gray on fresh exposures. The weathered rock is dark red brown or buff brown. The dark green-gray rock occurs near the base of some of the exposures; the color probably is caused by chlorite. Most of the basalt consists of a glassy or microcrystalline groundmass enclosing olivine crystals as much as $2 \mathrm{~mm}$ in diameter and plagioclase crystals as much as $6 \mathrm{~mm}$.

The interbeds of pyroclastic and sedimentary materials within the Picture Bock Basalt are of typical character at the following reference section, measured by G. M. Hogenson at a fault scarp in the NE $1 / 4 \mathrm{NW}^{1 / 4}$ sec. 8 , T. 28 S., R. 20 E., at the east end of the basin floor, about 6 miles south of Buffalo Wells. Threefourths of a mile farther south, along the same fault scarp, this interbed thickens to about 250 feet. There the sedimentary materials are of about the same composition as at the measured section but contain a thin flow of rhyolite.

Reference section of interbedded materials of the Picture Rock Basalt in NE1/4NW1/4 sec. 8, T. $28 \mathrm{~S} ., \mathrm{R} .20 \mathrm{E}$.

Picture Rock Basalt:

9. Tuff, basaltic, yellow-gray-brown, bedded; contains pebbles of gray to black scoria and pumice; upper part covered by talus

8. Conglomerate, pumiceous, light-gray, massively bedded; particles range from sand to cobble size, pebbles and cobbles predominate____-_-_ 10

7. Tuff (90 percent), yellow-brown (except in the lowest $3 \mathrm{ft}$, where the color grades to pinkish white); contains pebbles of white pumice and basaltic scoria ; pumice fragments increase in size upward to cobble size at the top_-_._-_-_-_- 25

6. Conglomerate, pumiceous, gray-white, crudely and massively bedded; maximum particle size 2 in.- 12
Reference section of interbedded materials of the Picture Rock Basalt in NE1/4NW1/4 sec. 8, T. 28 S., R. $20 \mathrm{E}$.-Con.

Picture Rock Basalt-Continued

5. Tuff, pumiceous, brownish-gray, finely to coarsely bedded; particles range from sand to pebble size; contains pebbles of glassy basaltic scoria as much as three-quarters of an inch in diameter.-..---

4. Conglomerate, pumiceous, white and gray, massive; maximum pebble size about 1 in

3. Sandstone, thinly bedded, fine- to coarse-grained--

2. Sandstone, granule conglomerate, tuffaceous, pumiceous; contains small pebbles of glassy basaltic scoria

1. Basalt

Total

This sedimentary section is capped by a flow of finegrained glassy basalt containing sparse phenocrysts of feldspar as large as $2 \mathrm{~mm}$ in diameter. This capping flow is scoriaceous at the top and finely vesicular to dense near its base.

As previously stated, the pyroclastic rocks between the basalt flows of the Picture Rock Basalt at the eastern border of the area are as thick as 250 feet. The exposed thickness of the basalt at the eastern edge of Silver Lake exceeds 700 feet, and the unit may reach thicknesses greater than 1,000 feet. The individual flows of basaltic lava range in thickness from 10 to 50 feet.

After its deposition, the Picture Rock Basalt was deformed into broad folds and broken by numerous faults. The two cones that constitute the volcanic rocks of intermediate composition apparently erupted along faults in the Picture Rock Basalt; thus, the volcanic rocks of intermediate composition lie unconformably upon the Picture Rock Basalt. Because the Picture Rock Basalt is the oldest unit mapped in the area, its relation to underlying units is not known.

On the basis of its stratigraphic position below volcanic rocks of intermediate composition and the Fort Rock Formation (p. B10), and the degree of its deformation, the Picture Rock Basalt is tentatively assigned an early (?) Pliocene age. Its relation to similar basalts in other areas of eastern Oregon is not known.

The Picture Rock Basalt apparently erupted as a very fluid lava because each flow layer is widespread-5 to 10 square miles. The flows of this unit probably issued at high temperature from local vents or fissures.

The general water-bearing properties of the Picture Rock Basalt are good. The zones of greatest permeability are mainly along the tops and bottoms of the flows, but even the denser middle parts of the flows have some permeability. Individual flows are generally thin, and the cinder or scoria zones, which have high porosity and permeability, make up a large part of the total rock unit at some places. These cinder and scoria zones, 
where they are penetrated below the water table, yield large amounts of water to wells.

\section{VOLCANIC ROCKS OF INTERMEDIATE COMPOSITION}

The volcanic rocks of intermediate composition comprise two volcanic masses that unconformably overlie the Picture Rock Basalt. These masses form Horning Bend and Cougar Mountain, both lava cones.

Horning Bend (fig. 3) occupies about 6 square miles in secs. $23,25-27$, and $34-36$, T. 26 S., R. 14 E., and secs. 1-3, T. 27 S., R. 14 E. Cougar Mountain covers about $11 / 2$ square miles in secs. $10,11,14$, and 15, T. 25 S., R. 15 E.

Horning Bend is composed of a fine-grained andesite that is light blue gray to cream where unweathered and light buff where weathered. The andesite has closely spaced rectangular and platy joints, and few of the individual joint blocks are more than a few inches in diameter.

Cougar Mountain, in secs. 10, 11, 14, and 15, T. 25 S., R. 15 E., is composed of a fine-grained to glassy rock probably in the rhyodacite class of extrusive igneous rocks. It ranges in color from dark pink to bluish gray on fresh surfaces and is cream to buff on weathered surfaces. The rhyodacite is both massive and flowbanded. Where the rock is banded, wide bands of light pink or cream color generally alternate with very narrow dark bluish-gray bands. The rock has a rough and varied appearance owing to the presence of partly filled vugs, to variations in texture from spongy to glassy, and to variations in color. Figure 5 shows variations in the texture and color of the rhyodacite on the west side of Cougar Mountain, in SW1/4NE1/4 sec. 15, T. 25 S., R. 15 E. The vug s $_{S}$ and vesicles are filled or

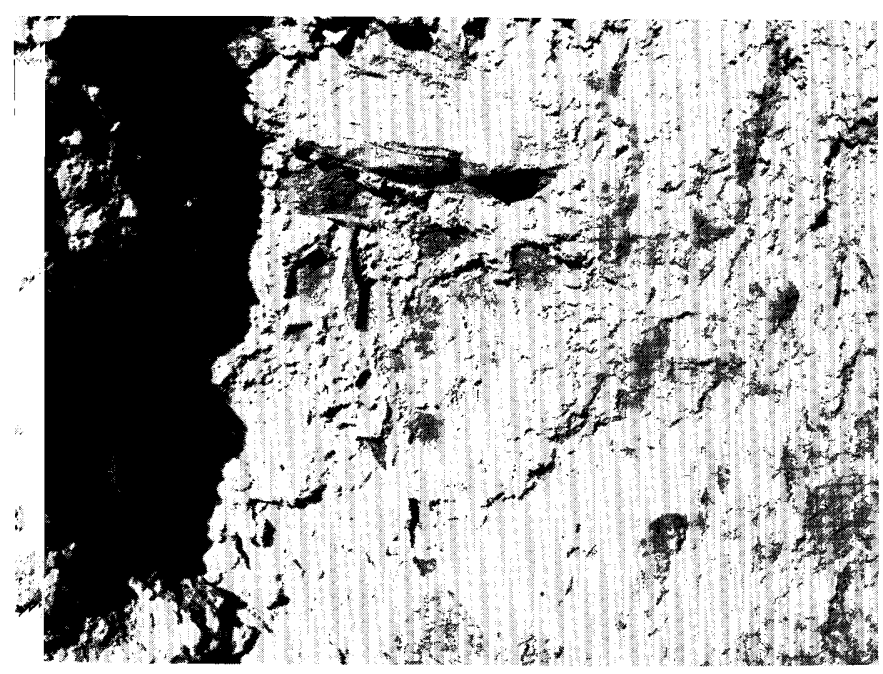

Frgure 5.-Rhyodacite on the west side of Cougar Mountain. The dark blotches are composed of shattered black obsidian; the light background is pink rhyodacite. partly filled by quartz crystals and amorphous silica. Iron oxide is present in some of the cavities, as are thin layers of clayey material.

The obsidian on Cougar Mountain is mostly black, but some of it contains red streaks and nearly all the obsidian is transparent or translucent on thin edges. The obsidian lies in streaks within the rhyodacite, and there is a complete gradation from frothy fine-grained light-colored rhyodacite to dense obisidian. The dark color of the obsidian is apparently caused by microlites of magnetite because the rock is slightly magnetic.

The andesite and rhyodacite of this unit weather to form thin, rocky soil. The andesite weathers to small buff to gray blocks and forms a buff soil, whereas the rhyodacite weathers to thin flakes and forms a graybrown soil that has fragments of glassy rhyodacite and obsidian dispersed through it.

The thicknesses of the rock masses forming Horning Bend and Cougar Mountain probably range from a few tens of feet to more than 1,000 feet. The thicker parts are at the central areas of the two eruptions. Horning Bend is the larger and the thicker of the two eruptive masses.

The volcanic rocks of intermediate composition that unconformably overlie the Picture Rock Basalt are unconformably overlain by the Fort Rock Formation at Horning Bend. Because the Fort Rock Formation near Cougar Mountain contains fragments of rhyodacite and obsidian identical with the rocks of that mountain, the rhyodacite of Cougar Mountain is probably also older than the Fort Rock Formation, and approximately equivalent in age and stratigraphic position to the andesite at Horning Bend.

Stratigraphic position alone suggests that the volcanic rocks of intermediate composition are probably of middle Pliocene age; they are tentatively so assigned herein. No correlations with named rock units of similar lithology in south-central Oregon are proposed at this time.

These volcanic rocks of intermediate composition erupted from central vents along the faults that cut the Picture Rock Basalt. Because the lavas were viscous, they did not spread out over large areas, as did the preceding flows of basalt, but formed relatively high, isolated cones. Both Horning Bend and Cougar Mountain have undergone minor faulting and have been strongly eroded.

No wells are known to obtain water from the volcanic rocks of intermediate composition.

\section{FORT ROCK FORMATION}

Unconformably overlying the volcanic rocks of intermediate composition and the Picture Rock Basalt is a sequence of volcanic and sedimentary materials herein 
named the Fort Rock Formation. The Fort Rock Formation is named for Fort Rock, a remnant of an eruptive center of this unit, which rises above the valley plains as a mesalike butte in secs. 29 and 30, T. 25 S., R. $13 \mathrm{E}$. in the western part of the area. Rocks of this unit are exposed over about 90 square miles of the basin, and much of the basin floor is underlain by this unit at shallow depths.

The areas where the Fort Rock Formation crops out are irregular and scattered (pl. 1), and there is no single exposure that is typical of the formation as a whole. Consequently, several reference sections at different localities are necessary to describe the formation adequately. One reference section that typifies the relationship of some of the pyroclastic rocks to sedimentary rocks is in NE $1 / 4 \mathrm{SW} 1 / 4$ sec. $33, \mathrm{~T} .27 \mathrm{~S} ., \mathrm{R} .17 \mathrm{E}$., and is herein designated the type section. However, the thicknesses of the sedimentary materials of the formation are better represented by the drillers' logs of wells 28/15-14H1, 28/14-21Q2, 28/16-5Q1, 27/16-34L1, 27/ 17-27L1, 27/17-13A1, 27/19-19G1, 27/18-6F1, 27/18$12 \mathrm{~A} 1,26 / 15-5 \mathrm{C} 1,26 / 15-6 \mathrm{C} 2,27 / 15-11 \mathrm{R} 2$, and $26 / 13-$ 25R1 (table 1).

Rocks characteristic of the Fort Rock Formation are exposed in the following parts of the area :

1. Surrounding Table Rock Butte, in secs. 30-32, T. 27 S., R. 16 E.; secs. 5-8 and 17-20, T. 28 S., R. 16 E.; secs. 25 and 36, T. 27 S., R. 15 E.; secs. 1 and 12 , T. $28 \mathrm{~S}$., R. $15 \mathrm{E}$. (underlying about $11 \mathrm{sq} \mathrm{mi}$ ). 2. At Seven Mile Ridge, in secs. 16, 17, 20, 21, 27, 28, and 32-35, T. 27 S., R. 17 E.; secs. 2-5 and 10-14, T. $28 \mathrm{~S}$, R. $17 \mathrm{E}$. (underlying about $10 \mathrm{sq} \mathrm{mi}$ ). 3. In the Fandango Canyon-St. Patrick Mountain area, where about 14 square miles are underlain by tuff, basaltic lapilli tuff, and intercalated basalt flows.

The Fort Rock Formation is composed principally of four rock types. They are, in order of abundance, tuff, diatomite, basaltic agglomerate, and basaltic lava.

The basalt and basaltic lapilli tuff are more resistant to erosion than are the ashy diatomite, diatomite, and fine-grained tuff. The more resistant masses of basaltic lapilli tuff remain as topographic highs such as Fort Rock and Seven Mile Ridge. Basalt and basaltic agglomerate are resistant caprock units for softer, less resistant ashy diatomite, diatomite, and fine-grained tuff.

A sandy light-brown soil is developed where basaltic lapilli tuff and fine-grained tuff are the principal rock types underlying the surface. A silty gray-brown or brown soil is developed where ashy diatomite and diatomite underlie the surface. Areas underlain principally by basaltic lapilli tuff, diatomite, and other relatively soft units, but also by one or more flows of basaltic agglomerate or basalt, are mantled by weathered basalt boulders and have much the same appearance as a weathered basalt flow.

The tuffs of the Fort Rock Formation include basaltic lapilli tuff and fine-grained tuff. Of these, the basaltic lapilli tuff is perhaps the most typical and most easily recognized rock of the Fort Rock Formation. It is yellow buff to dark gray brown or reddish brown. This rock occurs as bedded semiconsolidated tuff or welded tuff, or in massive nonbedded layers, probably derived from volcanic mudflows. The lapilli-sized particles in the rock are principally scoriaceous or cindery basalt, but at places the scoria or cinder lapilli are replaced by pumice lapilli and the rock is a pumice tuff. At those places, the pumice is generally light gray but rarely dark gray or black. The pumice fragments range in diameter from about $1 / 8$ to $1 / 2$ inch. Brick-red cinders and cinder tuffs occur at the top of the Fort Rock Formation in exposures in the northern part of the area. They range in texture and degree of induration from loose, friable cinders $1 / 8$ to $1 / 4$ inch in diameter to finer grained baked strongly indurated tuff. They directly overlie yellow or buff basaltic lapilli tuff and unconformably underlie the Paulina Basalt.

One of the best exposures of basaltic lapilli tuff and diatomite is in NE1/4 SW1/4 sec. 33, T. 27 S., R. 17 E., on the west side of Seven Mile Ridge. This section is designated the type section of the Fort Fock Formation because it is considered to be the most representative of the formation.

Type section of the Fort Rock Formation in NE1/4SW1/4 sec. 33, T. 27 S., R. $17 \mathrm{E}$.

Fort Rock Formation :

Feet

15. Mudflow, basaltic pumice, massive, buff-brown; fragments of basaltic scoria, pumice, and basalt commonly range from 3 in. to $1 \mathrm{ft}$ in diameter; upper part of unit obscured by brush $37.8+$

14. Mudflow, basaltic pumice, massive, buff-brown; fragments of basaltic scoria, pumice, and basalt range from 1 to $2 \mathrm{in}$. in diameter-_.-.- 6

13. Diatomite, cream to white ; some bedding -..-_ 12.3

12. Mudflow, basaltic, welded or cemented; tuff matrix is greenish gray buff ; fragments of basaltic pumice $1 / 1$ to $1 / 2 \mathrm{in}$. in diameter make up 20 percent, medium to coarse sand-size fragments make up 50 percent of the rock

11. Conglomerate, pumice, dark- to medium-gray, poorly cemented; fragments $1 / 4$ to $1 \mathrm{in}$. in diameter

10. Sandstone, pumice, diatomaceous, flne- to medium-grained

9. Sandstone, pumice, limonite cemented, rustcolored

8. Diatomite, ashy, gray; upper $0.2 \mathrm{ft}$ contains limonite layers 
Type section of the Fort Rock Formation in NE1/4SW1/4 sec. 33, T. 27 S., R. 17 E.-Con.

7. Diatomite, white

6. Sandstone, basaltic, and limonite-cemented diatomaceous sandstone, gray to buff

5. Diatomite, ashy, fine-grained, white

4. Sand, pumice, and limonite-cemented diatomite-_

3. Diatomite, fine-grained, white to gray

2. Diatomite, sandy, limonite-cemented; sand grains of basalt constitute 20 percent of rock

1. Diatomite, fine-grained, white; base covered by alluvium

Total

Where the tuff is composed entirely of fine particles, the rock is called fine-grained tuff. The fine-grained tuff is light gray to yellow gray and is composed of finegrained glass and rock fragments. The tuff was deposited in water and is generally well bedded. The bedded tuff that crops out in NE1/4.SW1/4, sec. 8, T. 26 S., R. 14 E., shown in figure 6, is typical of the Fort Rock formation. Some of the lighter colored tuff contains diatoms. The fine-grained tuff occurs both near and at great distances from the eruptive centers and is the predominant rock of the Fort Rock Formation at distance from the eruptive centers.

Diatomite and ashy diatomite occur.in the Fort Rock Formation in the Table Rock Butte-Seven Mile Ridge district and are exposed in some of the dry washes there and elsewhere in the area. The diatomite is white or creamy white and is semicompact but friable. It is composed principally of the microscopic siliceous skeletons of fresh-water algae (diatoms) that were deposited in a lake or lakes during the time the Fort Rock Formation was being deposited. Even the purest diatomite contains some very fine volcanic ash packed tightly between the diatoms. The ashy diatomite is generally more consolidated and cemented than the diatomite and is usually light gray to white. The diatomite is massive (unbedded), but the ashy diatomite is thin to thick bedded at places. Both the ashy diatomite and the diatomite weather to a light gray-brown soil.

The basalt occurs as flows or agglomerate in layers about 5 to 15 feet thick and is dark gray to dark red brown on weathered surfaces and dark gray on fresh surfaces. The flows of this unit generally display columnar jointing and are vesicular at the top. Near two eruptive centers (Table Rock Butte and St. Patrick Mountain) vertical and near-vertical basalt dikes, 2 to 6 feet wide, penetrate the tuffs of the Fort Rock Formation. The agglomerates contain boulders of basalt, as much as 3 feet across, in a matrix of tuff and cinders. They are mostly coarse basaltic debris that accumulated near the eruptive sources, but at places they contain so

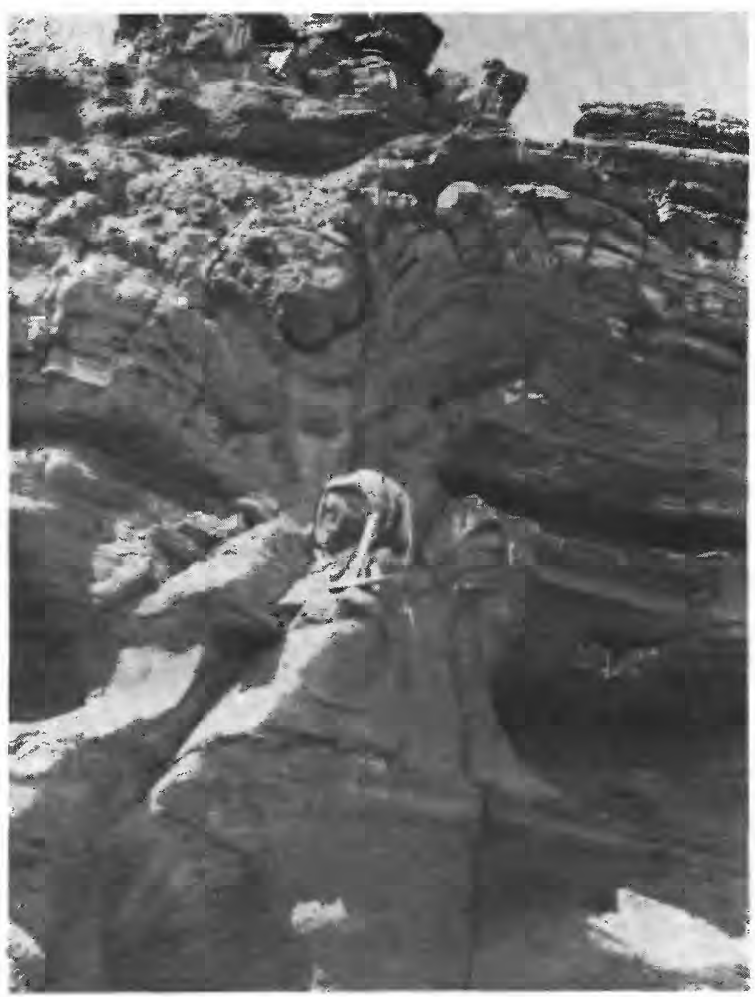

Figcre 6.-Bedded tuff of the Fort Rock Formation. Note the deformation caused by the large boulders of basalt that apparently dropped on and sank into the finer grained materials before the latter were indurated.

much massive basalt that they are almost a flow breccia of the lava. The surface of a weathered agglomerate looks like the weathered surface of a basalt flow.

The component sedimentary beds and flows of this unit range in thickness from about 10 to 200 feet. As indicated from well logs, the total thickness of the unit, where it fills the graben in the Picture Rock Basalt at Thorne Lake, is about 1,000 feet. The various eruptive centers reach maximum elevations of about 1,000 feet above the basin floors, as at Table Rock.

The Fort Rock Formation unconformably overlies volcanic rocks of intermediate composition. It also unconformably overlies, much more extensively, the older Picture Rock Basalt. In turn, the Fort Rock Formation is unconformably overlain by the Hayes Butte Basalt and younger units.

On the basis of stratigraphic position, lithologic similarity to rocks in adjacent areas, and fossil evidence, the Fort Rock Formation is tentatively assigned a middle and late Pliocene age.

A sample of the diatomite from the bottom of the measured section, but stratigraphically near the top of the pyroclastic rocks of the formation, was examined by K. E. Lohman of the Geological Survey. He identified 28 species and varieties of diatoms, 7 of 
which are extinct. Those extinct species and varieties are:

Diploneis ostracoderum (Pantoesek)

Melosira cf. sp. A

solida Eulenstein

cf. $M$. solida Eulenstein

Opephora n. sp. B

Stephanodiscus carconensis Grunow

cf. S. carconensis Grunow

According to Lohman (written comm., 1959), some of these extinct species have geologic ranges restricted to the late Pliocene. This evidence strongly suggests a late Pliocene age for the enclosing materials.

The rocks of the Fort Rock Formation are very similar to those of the Yonna Formation (Newcomb, 1958, p. 41-48) of the Klamath Basin, farther south. The Yonna Formation is probably of middle Pliocene age, based on vertebrate fossil evidence. Also, the Fort Rock Formation is lithologically similar to parts of the Danforth Formation of the Harney Basin (Piper and others, 1939, p. 43-49); the Danforth was tentatively dated as Pliocene. Because of the similar lithologies and also similar stratigraphic positions, these units may be at least partly contemporaneous with the Fort Rock Formation. However, the fossil evidence for dating all these formations is scanty, and the regions between the described areas are as yet unmapped; therefore, it is considered inadvisable to propose any but the most tentative correlation at this time.

The materials of the Fort Rock Formation were erupted from volcanic centers within and bordering the area and deposited in the basins formed by the Picture Rock Basalt. The eruptive centers are on the faults that cut the underlying Picture Rock Basalt, and several are preserved today as eroded remnants of former large cinder cones. One of the larger and most spectacular of remnants of these cinder cones, in secs. 29 and 30, $\mathrm{T}$. 25 S., R. 14 E., is called Fort Rock. Exposures there exhibit the bedding of the welded and cemented cinders near the center of the cone (fig. 7).

During the latest stages of some of the volcanoes of Fort Rock time, eruptions were progressively less explosive, and a higher percentage of basalt was extruded. As the eruptions stopped, basalt solidified in the craters. These crater fillings remain today as "caps" on the remnants of the volcanic cones. Both Table Rock Butte and St. Patrick Mountain are capped by remnants of such crater fillings, which from a distance look like parts of flows.

Of the Fort Rock Tuffs, some were laid down in water, whereas others appear to be the result of unreworked ash fall or volcanic muflow. Grain size in the respective pyroclastic units of the Fort Rock Formation generally decreases with the distance from the eruptive centers and sorting generally becomes better with distance. However, because some of the pyroclastic materials-for example, the pumice and cinders-are highly inflated and thus have low density, large particles of these inflated materials have been carried to places relatively distant from the eruptive centers. Accordingly, logs of wells 5 miles or more from the mapped eruptive centers show pumice and cinder particles as large as gravel size.

The various types of rock composing the Fort Rock Formation have greatly different water-yielding properties. In general, the finer grained tuffs and diatomite yield quantities of water adequate only for stock and domestic supply, whereas some of the coarser grained basaltic agglomerates, cinders, and basalt flows yield moderate to large quantities of water to wells. Over

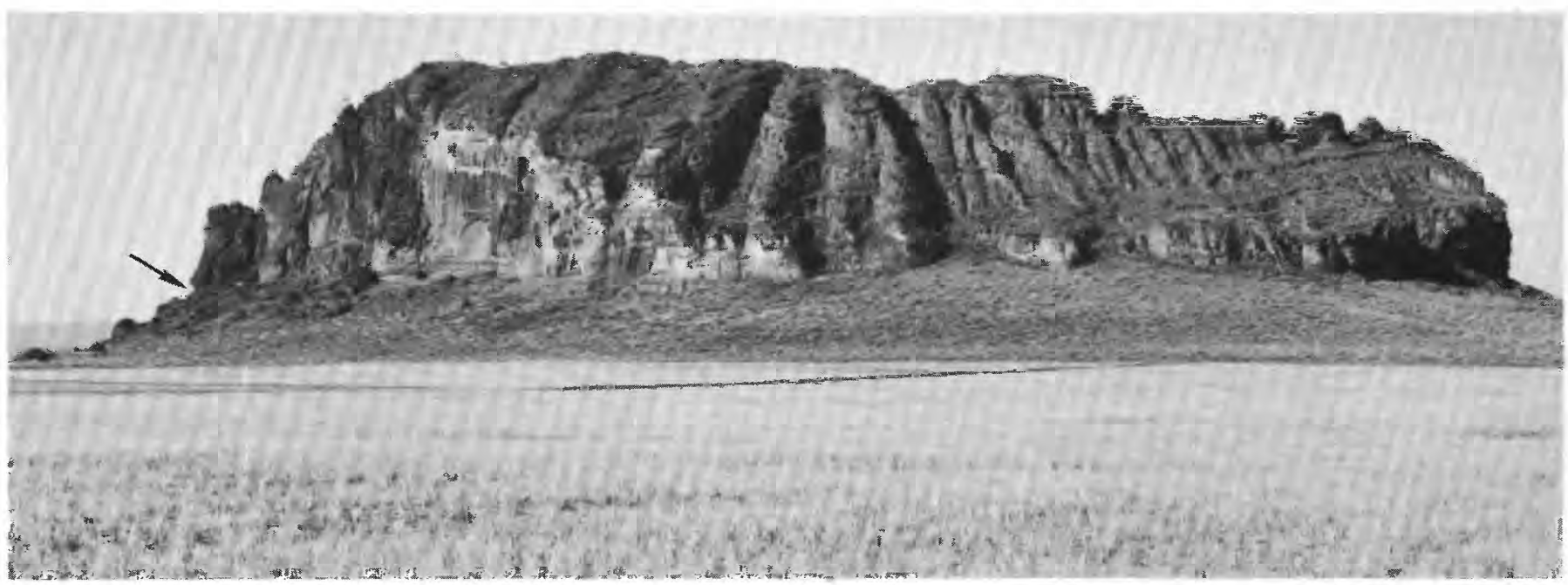

Figdre 7.-Fort Rock viewed from the northeast. Note the bedding of the cemented cinders that dips toward the observer. Notch and bench at left edge (at arrow) are wave cut. 
large tracts of the Fort Rock and Christmas Lake subareas, drillers report "black sand" and medium to coarse "pumice gravel" as productive water-yielding units. These coarse-grained deposits probably accumulated at distances of less than 2 miles from the eruptive centers. Closer to the eruptive centers, the sedimentary materials of the Fort Rock Formation are apparently poorly sorted and more tightly cemented, and thus yield only small to moderate quantities of water to wells. Likewise, at a distance of several miles from the eruptive center, the materials of this formation are better sorted and consist mainly of fine-grained materials of generally poor permeability.

Most of the sedimentary beds of the Fort Rock Formation are somewhat friable but will generally stand unsupported in a well. Some uncased or improperly constructed wells obtain large quantities of water from medium to coarse basaltic sand but pump appreciable quantities of sand with the water.

\section{HAYES BUTTE BASALT}

One of the most widespread rock units in the Fort Rock Basin is the Hayes Butte Basalt, herein named for Hayes Butte, the basaltic lava cone pictured in figure 3. Besides Hayes Butte, whose crest is in sec. 8, T. 27 S., R. $15 \mathrm{E}$., the principal areas of occurrence are the upland area a few miles west of Hayes Butte, Table Mountain, Wildcat Butte, and most of the slope off Hager Mountain. About 190 square miles of the mapped area is underlain by this unit.

As with the other units of lava or pyroclastic materials, no one exposure is typical of the unit as a whole. However, typical exposures of Hayes Butte Basalt in all its phases, from scoria piles to rather orderly layered basalt flows can be observed at several localities on Hayes Butte. Therefore, Hayes Butte and its lava shield to the south, in T. 27 S., R. 15 E. and northern T. 28 S., R. $15 \mathrm{E}$., are herein designated the type locality of the unit.

The Hayes Butte Basalt weathers to a thin brown rocky soil. Scoria of this unit weathers more rapidly than glassy dense lava; thus, deeper less rocky soils are formed on the scoria. In general, soils derived exclusively from Hayes Butte Basalt are too rocky for cultivation. However, where scoria is mantled by thin layers of wind- or water-deposited silts and sands, the land has been cultivated.

Like the older and younger basalts in the area, the Hayes Butte Basalt is light to dark gray on fresh surfaces and reddish brown to dark gray brown on weathered surfaces. The texture of the rocks in this unit ranges from diktytaxitic lava and open frothy scoria to dense glassy ropy lava. Where individual flows are exposed in fault scarps, they display a thin scoriaceous, glassy, or brecciated base, a dense fine-grained center, and a vesicular to rubbly top zone, which may be as much as 5 feet thick. The dense centers of the flows generally are jointed vertically into polygonal columns. Most of the lava of the Hayes Butte is basaltic, but the composition of some of the light-gray and glassy rock may approach that of an andesite.

The systematic layering of lava flows ceases near the eruptive centers, where simple flows merge into chaotic piles of scoria, tuff, and blocky and ropy lava. The rough surfaces of the Hayes Butte Basalt eruptive centers are due primarily to the weathering of the uneven textured lava and volcanic ejecta, and not to the irregularities of the original flow structures as at younger eruptive centers of the Paulina Basalt and Recent volcanics.

The basalt flows of the Hayes Butte Basalt range in thickness from about 10 to 30 feet. The thickness of this unit, as measured from the peak of Hayes Butte, exceeds 1,300 feet. At most exposures this unit occurs as one or two basalt flows, whose combined thickness does not usually exceed 100 feet. The number of flows and, thus, the thickness increase west of Hayes Butte; about 150 feet of the unit is exposed in the fault scarp that bounds the northwestern part of Paulina Marsh.

The Hayes Butte Basalt unconformably overlies the Fort Rock Formation and the older volcanic rocks. It is overlain unconformably by the Peyerl Tuff and the Paulina Basalt and, locally, by some of the younger units.

Because of its stratigraphic position, the Hayes Butte Basalt is tentatively assigned to the late Pliocene, although it may conceivably range into the early Pleistocene. Some of the youngest Hayes Butte Basalt flows may be age equivalents of some of the older Paulina Basalt flows (p. B14), and are approximately equivalent to the "upper lava rocks" (Newcomb, p. 21, 1958) of the Klamath Basin.

The Hayes Butte Basalt was erupted from centralized areas, generally along one of the strong northwestward-trending fault zones. The larger cones, such as Hager Mountain and Hayes Butte, are each about 4 miles across; smaller cones are only a few hundred to a few thousand feet across at the base. Near most of the eruptive centers, the floods of lava flowed down slopes underlain by Fort Rock Formation or Picture Rock Basalt and formed sloping lava plains such as the one south of Hayes Butte.

The Hayes Butte Basalt has undergone some faulting. The displacement on the faults cutting this unit is less than 50 feet at most places, but displacements on some of the faults in T. 26 S., R. 13 E., exceed 100 feet. 
The outcrops of the scoria and scoriaceous, brecciated zones at the top of individual flows appear to be highly permeable. If flows of Hayes Butte were penetrated by wells below the water table, they would probably yield large quantities of water. However, in the areas of existing wells, the Hayes Butte Basalt apparently does not extend below the water table, and where the Hayes Butte probably extends below the water table, as at the northwest end of Paulina Marsh, no deep wells have been drilled.

\section{TERTIARY AND QUATERNARY ROCKS PEYFRL TUFF}

Through about 10 square miles of the area, in the vicinity of Peyerl Ranch (sec. 10, T. 26 S., R. 13 E.), the Hayes Butte Basalt is unconformably overlain by a sequence of tuff, tuffaceous sandstone, and pumice conglomerate. This tuffaceous unit is herein named the Peyerl Tuff.

The unit is well exposed in the roadcut of State Highway 31 in sec. 31, T. 25 S., R. 13 E., which is herein designated the type section of the formation, and is also fairly well exposed at an erosional escarpment where crossed by a county road in sec. 28, T. 25 S., R. $13 \mathrm{E}$. The lithology of the unit is well described in the following section measured at the type section by G. M. Hogenson:

Type section of Peyerl Tuff measured along 11/2-mile highway cut in sec. 31, T. 25 S., R. $13 \mathrm{E}$.

Paulina Basalt:

35. Basalt, forms rimrock

Unconformity (?)

Peyerl Tuff :

34. Tuff, caprock, tannish-yellow or pink, rhyolitic, welded, platy; bottom 4-5 ft. gray pumiceous tuff, containing scattered fragments of pumice, lava, and obsidian; grades upward into platy, banded welded rhyolitic tuff; upper part of unit obscured by slumped blocks of Paulina Basalt

33. Sandstone, reddish-brown, tuffaceous, rudely bedded; contains lenticular layers of lapilli and scattered pebbles of weathered pumice as large as $1 \mathrm{in.}$ in diameter.

Feet

32. Covered interval

31. Sandstone, reddish-brown, tuffaceous, massive; contains about 20 percent fragments of pumice and red and gray lava as large as 1 in. in diameter; scattered fragments of gray pumice up to $12 \mathrm{in}$. in diameter.

30. Covered interval

29. Tuff, gray, pumiceous ; about 75 percent is sandsize or smaller, 20 percent is gray and buff pumice less than 1 in. in diameter, and 5 percent is gray pumice fragments 1-10 in. in diameter

28. Covered interval
Type section of Peyerl Tuff measured along 11/2-mile highway cut in sec. 31, T. 25 S., R. 13 E.-Con.

Peyerl Tuff-Continued

27. Sandstone, yellow-brown, tuffaceous, bedded; platy parting mostly slumped and covered_-

26. Pumice, yellow-brown, well-indurated (welded?) ; contains a few fragments of obsidian.

25. Sandstone, tuffaceous, reddish-brown to yellowish brown; contains scattered fragments and pebbles of gray pumice

24. Covered interval

23. Sandstone, tuffaceous, yellow-brown, massive; contains scattered small fragments and pebbles of gray to tan pumice.

22. Sandstone, tuffaceous, gray, crossbedded and lenticular; contains gravel of fragmental gray pumice

21. Tuff, sandy, reddish- or yellowish-brown, thinly bedded; cemented in part with iron oxide

20. Tuff, sandy, red, massive; speckled with scattered small fragments of white and gray pumice

19. Mostly covered; one slumped outcrop of darkgray sandy tuff

Feet

6

4

7

8

2

3

2

3

18. Tuff, sandy, light-reddish to yellowish-brown; contains scattered fragments of pumice....

17. Conglomerate, sandy, gray to brown; composed of crossbedded pumice.

16. Sandstone and conglomerate, tuffaceous, lenticular; lenses as much as $50 \mathrm{ft}$ long and $\mathbf{1 2}$ in. thick; appear fairly well sorted but all layers contain scattered pebbles and small cobbles of pumice

15. Sandstone and conglomerate, tuffaceous, lightgray to light-brown; pebbles are gray pumice ; lenses as thick as 12 in., the thicker ones being crossbedded or containing smaller lenses ; most pumice fragments less than 2 in. across, but some as much as 6 in

14. Sandstone, tuffaceous, gravelly, pink-gray, unsorted; gravel particles are subangular to well-rounded gray pumice.

13. Claystone and sandstone, tan, pink, and yellowbrown, in layers $1 / 4$ to 1 in. thick; contains a few pebbles of gray pumice less than 2 in. in diameter.

12. Sandstone, tuffaceous, fine-grained, pinkishgray ; contains a few pumice shards as much as half an inch in diameter.

11. Sandstone, fine- to coarse-grained, bedded, lenticular, poorly indurated ; contains lenticular beds of fine-grained gravel

10. Gravel, unsorted, sandy tuff matrix; contains subrounded to rounded gray pumice, pea sized to 2 in. in diameter

9. Conglomerate, sandy, and shale; lenticular layers, shaley partings one-eighth of an inch thick, conglomerate layers as much as 5 in. thick; gravel particles of angular to subrounded gray pumice. 
Type section of Peyerl Tuff measured along 11/2-mile highway cut in sec. 31, T. 25 S., R. 13 W.-Con.

Peyerl Tuff-Continued

8. Tuff, fine-grained, sandy, gray-brown; contains some grit-sized angular particles of gray or red lava and pumice as much as 1 in. in diameter

7. Covered interval

6. Tuff, sandy, grayish-brown, speckled with angular to subrounded fragments, half an inch in diameter, of light-gray to tan pumice

5. Covered internal-_.-.

4. Tuff, gray, reddish-brown, in upper $12 \mathrm{ft}$; glassy matrix contains fragments of pumice, some fragments of dark scoria and black obsidian; most fragments less than 1 in. in diameter, some as much as 3 in.

3. Covered interval

2. Tuff, pebbly, white to tan, lenticular, crossbedded; white where ashy tuff and pumice predominate; some lenses as thick as 12 in...

1. Tuff, dark-reddish-brown, cemented with iron oxide; contains 50 percent pebbles; gravel and grit composed of white pumice, black or gray scoria, and gray lava; most fragments less than three quarters of an inch in diameter; base not exposed.

Total $226.5+$

Another reference section of this unit, measured at the aforementioned scarp in sec. 28 , T. 25 S., R. 13 E., includes two locally distinctive and fairly extensive beds that are useful as mapping horizons but that were not present at the type section. These are a layer of reddish-brown sandy silt directly underlying the caprock of welded rhyolitic tuff, and a 30-foot-thick bed of dark-brown welded tuff about 110 to 140 feet below the caprock welded tuff. The exposure at this scarp, which is about 2 miles east of the type locality, also shows the lithologic diversity in the unit within short distances.

Section of Peyerl Tuff where a county road crosses an erosional escarpment in center part of sec. $28, T .25 \mathrm{~S} ., R .13 \mathrm{E}$.

Peyerl Tuff :

8. Tuff, caprock, tannish-pink, rhyolitic, welded, platy parting ; contains drawnout fragments of lava of an intermediate composition; top of unit eroded

7. Silt, brownish-red, sandy, tuffaceous, massive ; contains scattered particles of white tuff, black obsidian, and gray lava

6. Conglomerate, reddish-brown, moderately indurated; sandy tuffaceous matrix; subrounded pebbles as much as $1 \frac{1}{2}$ in. in diameter but most less than $1 / 2$ in. ; composed of basaltic scoria, pumice, and light-gray lava

5. Sandstone, reddish-brown, tuffaceous, silty, moderately indurated, massive; contains some par-
Section of Peyerl Tuff where a county road crosses an erosional escarpment in center part of sec. $28, T$. $25 \mathrm{~S} ., \mathrm{R} .13 \mathrm{E} .-\mathrm{Con}$.

Peyerl Tuff-Continued

Feet

ticles of lava and pumice as large as 3 in. in diameter

4. Covered by slope wash

3. Breccia, tuffaceous, light- to dark-brown; about 60 percent composed of matrix of coarse tuff and basaltic lapilli, remainder cobble- and bouldersized pieces of rounded to angular basalt scoria and pumice as large as 12 in. in diameter..... 6

2. Covered interval__-_-_- 52

1. Tuff, welded, chocolate brown; contains angular fragments of lava, black pumice, and frothy glass as large as $1 \frac{1}{2}$ in. in diameter; base not exposed

\section{$30+$}

Total-_-

The foregoing data show that, although this^unit has a diversity of rock types, it is composed mostly of tuffaceous, pumiceous volcanic materials of intermediate composition, most of which were waterlaid. The tuffs of this formation weather rapidly to form a sandy to clayey reddish- to tannish-brown soil. The welded tuff caprock and welded tuffs within the unit are moderately resistant and weather less rapidly. All the rocks constituting the Peyerl Tuff are less resistant than the overlying Paulina Basalt, which forms a rimrock over the Peyerl at several localities.

As shown in the sections just described, individual beds of this unit range in thickness from a few inches to about 30 feet. The total exposed thickness of the unit at the type section is about 227 feet, and the thickness recorded in the drillers' $\log$ of the nearby well $26 / 13-4 \mathrm{~B} 1$ is 160 feet. This well apparently entered the tuff at a stratigraphic horizon nearly equal to the base of the measured section at the type section; therefore, the total thickness of the Peyerl Tuff near the type section may be 400 feet.

The Peyerl Tuff unconformably overlies the Hayes Butte Basalt, is unconformably overlain by flows of Paulina Basalt, and is in part contemporaneous with the lower part of the Paulina Basalt. The relationship of the tuff to other units is shown on the geologic cross section $A-A^{\prime}$ (pl. 1).

Because of its stratigraphic position, the Peyerl Tuff is considered to be of latest Pliocene or early Pleistocene age. No correlations with units in adjacent areas are suggested at this time.

The Peyerl Tuff was deposited in a rather small basin on the western edge of the present Fort Rock Basin. The sources of the Peyerl materials probably were rather small explosive-type eruptive centers located west of the present-day areas of outcrop. Most of the beds of the unit are waterlaid, although some appear to be of mudflow origin. The rhyolitic tuff at 
the top of the unit may have been deposited by a glowing cloud, because much of the upper part of this bed is welded. The Peyerl Tuff has undergone minor faulting but shows few traces of folding of the nearly flat-lying beds.

Records of a few wells drilled and dug into this formation indicate that the regional water table lies below its base; thus, the water-transmitting characteristics of this unit are unknown.

\section{PAULINA BAsatT}

Unconformably overlying the Peyerl Tuff is the Paulina Basalt, which is the main lithologic unit underlying the area that borders the northern part of the basin. This unit is herein named for the Paulina Mountains, which are northwest of and adjacent to the Fort Rock Basin. These mountains include many of the eruptive centers for the Paulina flows. The unit underlies about 370 square miles of the mapped area. The unit occurs as intertonguing flows from a number of low shield volcanoes, many of which lie to the north of the Fort Rock Basin. The type area of the Paulina Basalt is herein designated as secs. 1 and 2, 11 and 12, T. 26 S., R. 16 E., where five overlapping flows from possibly three different sources are exposed.

Because the older flows of the Paulina have weathered longest, they have smoother surfaces than the younger flows. Most of the flows are only moderately weathered and have a very thin residual soil cover. The soil is light brown and very rocky. At some places tillable windblown soil overlies the basalt to depths of several feet.

The Paulina Basalt is dark reddish brown on weathered surfaces and dark gray on fresh surfaces. It has the diktytaxitic texture common to many Pliocene and Pleistocene basaltic lavas. The flows are usually brecciated slightly on the bottom, dense in the middle, and brecciated and scoriaceous on the top, although there is some local variation of this sequence. Most flows are somewhat vesicular throughout, but especially so in the top 2 to 4 feet. The basalt is separated into either polygonal or irregular blocks by joints that are relatively widely spaced in the dense centers of the flows.

In gross texture the surfaces of the various flows range from moderately rough to very rough; the roughness is due almost entirely to the original flow structures, such as pressure ridges, ropy flow surfaces, and blocky breccia.

Individual flows of the Paulina Basalt range in thickness from about 5 to 20 feet. When extruded, the lava apparently was only moderately fluid; hence, great variations in the thickness of any one flow are common. The total thickness of the unit is not known but probably exceeds 1,000 feet near eruptive centers.

The Paulina Basalt unconformably overlies the Peyerl Tuff and, where the Peyerl is absent, the Hayes
Butte Basalt. It is unconformably overlain by younger basalt and by unconsolidated deposits.

The general period of volcanic activity in the Paulina Mountains, during which the Paulina Basalt was extruded, may have extended in time from late Pliocene to Recent. The earliest lava flows in the Paulina Mountains (which underlie the flows mapped as Paulina Basalt) probably are equivalent in age to part of the Hayes Butte Basalt. The latest flows in those mountains, which are equivalent to the flows herein described under "Younger basalt," are Recent in age. The Paulina Basalt, as designated herein, is tentatively assigned to the latest Pliocene (?) and Pleistocene ages. No correlation with basaltic units of this general age range in other parts of eastern Oregon is suggested at this time.

The Paulina Mountains constitute the principal center of eruption of the unit. The Paulina Basalt exposed in the Fort Rock Basin was erupted from centers oriented along the northward-trending fault zones that are within or adjacent to the northern part of the basin. A typical example of one of these centers is Bunch Grass Butte, a low volcanic shield in the northeastern part of the basin. Green Mountain is another, although larger and steeper, volcanic shield in the north-central part of the basin. Flows of the Paulina Basalt have undergone minor faulting; displacements along the faults seldom exceed 20 to 50 feet, and in most places are 5 to 10 feet.

In outcrop the Paulina Basalt appears to have good vertical and horizontal permeability, and wells that have penetrated this unit below the water table yield large quantities of good-quality water.

\section{QUATERNARY ROCKS}

\section{UNCONSOLIDATED DEPOSITS}

The surficial sedimentary materials that overlie the older volcanic and sedimentary rocks throughout the Fort Rock Basin are grouped together in this report as unconsolidated deposits. Included in the unconsolidated deposits are: lakebed deposits and associated terrace, spit, bar, and deltaic deposits of Pleistocene age; and stream-valley alluvium, playa deposists, and windblown sand and silt of Recent age. Because the materials of this unit form only a thin cover over the older rocks in most of the basin area, and thus do not extend below the water table, they are, with the exception of the large masses of dune sand, mapped as a geologic unit on plate 1 . The various deposits in this unit are described in some detail in the following paragraphs.

\section{LAKEBED AND TERRACE DEPOSITS}

The lakebed and terrace deposits are in part contemporaneous with, and in part unconformably overlie, 
the Paulina Basalt. These sedimentary deposits probably range in age from early to late in the Pleistocene Epoch. They accumulated in a large lake that occupied the bottom of the Fort Rock Basin during the times of greater precipitation and lesser evaporation that occurred during parts of the Pleistocene.

At places along the borders of the valley plains, deposits of this unit overlie each of the older units described in this report. A thin layer of fine-grained material was laid down over the entire area covered by the Pleistocene-age lake and now underlies the valley plains. The highest level at which the lake stood was about 4,500 feet in altitude, but this level apparently was mantained only briefly. One of the high levels maintained for a longer time is that from about 4,450 to 4,400 feet. At about the 4,400-foot level around the edges of the basin are wave-cut terraces, wave-built terraces, spits, and bars, which are shoreline evidence of this lake stage. The material underlying the wave-built terraces consists of sand and gravel. The spits and bars are composed of materials similar to, although somewhat finer grained than, the deposits underlying the terraces.

Fine-grained lacustrine, or lake, deposits-consisting of clay, silt, sand, volcanic detritus, and diatomaceous earth-mantle the former lakebed. Obsidian chips ranging from pebble to cobble size are widespread over the surface of these lacustrine deposits in the Christmas Lake and Fort Rock Valleys. Because the lacustrine deposits are uniformly fine grained, it is unlikely that heavy fragments of obsidian were incorporated within these sediments over a major part of the basin. One obvious source of the obsidian is the obsidian-bearing basaltic lapilli tuff of the Fort Rock Formation, which underlies large areas in the Christmas Lake and Fort Rock Valleys. Weathering of this tuff apparently loosened the resistant obsidian chips, and, where only a foot or two of lacustrine deposits overlies the tuff, the obsidian has been heaved by frost action to the surface. In some places where obsidian chips form a virtual pavement on the windswept surface of the lacustrine deposits, there are signs of former arrowhead manufacturing.

In outcrop, the lacustrine deposits underlying the terraces and the bars or spits range in color from dark gray brown to light gray or light brown. The color depends mostly on the color of the component cobbles and pebbles, but also on the degree to which these pebbles have been coated by the cream to gray caliche that is characteristic of this region. The cobbles and pebbles in these deposits consist of basalt, welded tuff, and other resistant rock that is available in the immediate vicinity of any particular reach of terrace.
The grit, sand, and finer particles consist of rock fragments and pumice.

The clay, silt, and sand-sized particles constituting the lakebed sediments are light gray and light brown and are thinly bedded. The particles consist of finegrained volcanic detritus and diatoms.

The deposits that underlie the terraces, bars, and spits of the Pleistocene lake deposits are virtually unweathered. The fine-grained lacustrine deposits of the old lakebed also are only slightly weathered, although large volumes of these deposits have been eroded away by wind and rain. The finer grained lacustrine deposits constitute the soil and subsoil of much of the farmed land in the Fort Rock Basin and are recorded as soil in most well logs.

\section{DELTA DEPOSITS}

In the parts of the basin where streams entered the Pleistocene-age lake, deposits of gravel, sand, silt, and clay-sized materials were laid down in the form of deltas. Remnants of these deltas are present around the southern edge of Paulina Marsh, at the mouths or along the lower reaches of the present-day streams. Silver and Bridge Creeks are separated in their lower reaches by a remnant of a delta that remains as a low terrace of bedded medium-sized gravel and sand, and the lower course of Buck Creek has valley walls of unconsolidated deltaic gravel and sand. Fine-grained, crossbedded, and deformed delta deposits occur along the lower reaches of Murdock Creek, about 3 miles west of the western edge of Silver Lake.

\section{DUNE SAND}

The wind-laid sands have been derived principally from the Pleistocene lakebed deposits. They form dunes that extend over wide areas in the Fort Rock Basin. High dunes of moving sand cover about 23 square miles in the area east of the playa known as Christmas Lake (pl. 1). Lower dunes, now nearly stabilized, are widespread in the basin.

The sand particles in the dunes consist of volcanic glass, fragments of diatoms, pumice, and basalt. The dunes are light tan to cream tan.

The dune sand is moderately permeable, and thus more readily permits the infiltration of water than do the more consolidated rocks in the area. In many places where dune sand overlies a less permeable rock, such as tuff or basalt, a zone of perched ground water is contained in the sand above the water table by the less pervious rock. A prime example of the occurrence of such a zone of perched ground water is found at Lost Forest, at the east side of the Fort Rock Basin, where about 10 feet of dune sand overlies tight clay- 
mantled basalt, which perches or retards the downward movement of ground water in the bottom part of the sand. This thin zone of perched ground water is the source of water for the pine trees of Lost Forest and is also tapped by one or two stock wells.

The dune sand, like the scraggly surfaced young lavas, is important in routing infiltrating water underground, where it may escape evaporation and transpiration and thus may reach the regional ground-water body.

\section{STREAM-VALLEY ALLUVIUM}

The channels and flood plains of the lower reaches of Silver, Buck, and Bridge Creeks and of many of the intermittent streams and arroyos are underlain by thin deposits of sand, gravel, and rock rubble; the meadows in the uplands along these creeks are underlain by fine-grained surficial deposits. These sedimentary deposits, of Recent age, constitute the small amounts of stream-valley aluvium. They underlie about $1 \frac{1}{2}$ square miles in the area.

The gravel in the stream-valley alluvium is composed of basalt, volcanic cinders, and pumice. The sand is generally composed of volcanic glass or particles of basalt and pumice. The clay and silt are the products of weathering of the upland soils and reworked materials from older fine-grained sedimentary and pyroclastic rocks.

The coarser grained stream-valley alluvium yields moderate quantities of water to wells. One well dug into this material is known to supply water for a farmstead. The total depth of the alluvium at that well $(28 / 13-14 K 2)$ is 10 feet. Most of the alluvium lies above the level of the channels that carry the meager summer streamflow; hence, the alluvium is generally drained during part of the year and does not supply water to wells perennially.

\section{YOUNGER BASALT}

The youngest basaltic lava flows and cinder cones exposed in the northern Fort Rock Basin are included in the unit designated younger basalt. Lavas of this unit underlie about 15 square miles of the mapped area along the northern border of the basin.

The most recent flows are in secs. 22, 23, 26-28, and 33-35, T. 25 S., R. 17 E., and secs. 1, 2, 11, and 12, T. 26 S., R. 17 E. Associated with these flows are four cinder cones that are alined along a northwest-striking fault (pl. 1).

The younger basalt is virtually unweathered. The earliest flows of this unit have somewhat smoother surfaces than the latest flows, but all flows have very rough, scraggly surfaces and are black to reddish black-evi- dence that the minerals in the rock have not undergone much chemical breakdown.

Most rocks included in this unit are basaltic lavas; some, however, are basaltic cinders that form cones both within or distant from the central areas of eruption. The younger basalt flows are composed of dark-gray to black vesicular lava.

The flows possess almost all their original flow structures. Most of the lava examined is blocky, broken vesicular lava that is in part loosely imbedded in less shattered vesicular lava. The surface of each flow shows lateral variations from rough, scraggly heaps of broken lava blocks to solid ropy lava.

Cinder cones of this unit are composed of inflated granular loose reddish-brown to black basalt.

The total thickness of the various young lava flows ranges from about 5 to 50 feet. The centers of eruption and the piles of cinders are as much as 200 feet thick.

The younger basalt was deposited on the surface formed by the overlapping basaltic shields of the Paulina Basalt. The rocks of the unit represent the youngest lava flows in this basin and are considered to be of Recent age. This unit has the same mode of origin as the Paulina Basalt-that is, moderately to highly liquid lava was erupted from central areas and spread out over the preexisting landscape in circular masses, as shown on plate 1 .

Because all the younger basalts are above the regional water table, they are not aquifers in the Fort Rock Basin. These basalts appear to be highly permeable; therefore, they may be important as inlets by which precipitation can be carried underground to the underlying older basalts and other water-bearing rocks.

\section{GEOLOGIC STRUCTURE}

The Fort Rock Basin is a compound structural depression that was formed by deformation at various intervals from middle Tertiary to Quaternary time. The topography and drainage of the basin are intimately related to the geological structure, as are the occurrences and thicknesses of some of the rock units. To understand the occurrence and availability of ground water in the area, it was necessary to determine the sequence of structural events-such as folding, faulting, and subsequent eruption along faults-and the effects that these events had on the surface extent and subsurface continuation of the water-bearing units.

\section{ForDs}

Although there are several major folds within the Fort Rock Basin, the axis of only one, the St. Patrick anticline on the southern edge of the basin, can be depicted with reasonable accuracy on the geologic map. 
The axis of this fold is approximately as shown on the map, although the fold is broken by many cross faults. The Fort Rock-Christmas Lake Valley is probably a broad downwarp (syncline), the north limb of which may extend beyond the area of this study. On the south side of this valley the general northward inclination of the rock layers is clearly evident, but on the north side, rocks that presumably would show a southward dip are covered by the Paulina Basalt.

The St. Patrick anticline is named after St. Patrick Mountain-a vent that had contributed volcanic material to the Fort Rock Formation-which is the highest peak on the arch. The axis of the anticline follows an arcuate course from Picture Rock Pass east-northeast to St. Patrick Mountain, then trends southeast to the vicinity of Sheep Rock (pl. 1). The anticline is slightly asymmetrical; the rock layers of the northern limb dip $2^{\circ}-5^{\circ} \mathrm{N}$. and those of the southern limb dip $7^{\circ}-10^{\circ} \mathrm{S}$. The rock units involved in this upwarp are the Picture Rock Basalt and older underlying units that are not exposed in the Fort Rock Basin.

The folding which depressed some of the water-yielding units to depths below the present-day basin floor provides a favorable setting for the occurrence of artesian (confined) ground water, as noted by Waring (1908, p. 58-59). Although no flowing wells have been reported to date (1962), the driller's record of water levels in well 27/16-34L1 (table 1) indicates that the fine-grained materials of the Fort Rock Formation and the center parts of the Picture Rock Basalt flows act somewhat as confining layers for the water in the permeable parts of these units. Thus, despite the fact that in some parts of the basin the water-yielding units have been folded to considerable depths below the present basin floor, the water in those units will rise in wells to levels that permit economic pumping for irrigation.

\section{FAUUTS}

The most important structural elements of the Fort Rock Basin are the northward-trending faults. Those observed were all normal faults. The northwardtrending system of faults apparently developed simultaneously with the folds, presumably starting in early or middle Pliocene time. Movement along the faults has occurred intermittently throughout the period from early or middle Pliocene to Recent time, whereas the folding apparently ceased with the deformation of the Picture Rock Basalt. Each rock unit younger than the Picture Rock Basalt is cut by faults but apparently has been subject to little, if any, warping.

The vents and eruptive centers of volcanic units younger than the Picture Rock Basalt are alined along fault zones; thus the areal distribution of the younger units is partly controlled by the early faulting. Similarly, the variations in the thickness of the more extensive units, especially the Fort Rock Formation, are controlled by the locations of the horsts (uplifted blocks) and grabens (downdropped blocks) formed by faulting of the Picture Rock Basalt.

Most major faults in the Fort Rock Basin strike northwest, but some that cut the Picture Rock and Hayes Butte Basalts in the southeastern part of the basin strike due northeast or north. Vertical displacements are greatest along the older faults that do not affect units younger than the Picture Rock Basalt. Vertical displacements at different places range from a few feet to about 800 feet along those older faults. The displacements are smaller along faults in the succeeding units and rarely exceed about 100 feet along faults cutting units younger than the Picture Rock Basalt.

A few minor faults in the Fort Rock Basin intersect the northward-striking faults at nearly right angles. The vertical displacement along these east-west faults is generally less than 50 feet but at places exceeds 100 feet.

In regard to ground-water occurrence and development, the main importance of the faults is their role in depressing or elevating the various water-bearing rock units. So far as is known, the broken rock of the fault zones in the Fort Rock Basin does not form effective barriers to the horizontal movement of water in the lava rocks as do fault-breccia zones at other places in the Northwestern United States (Newcomb, 1961). Rather, the fault zones at many places in the Fort Rock Basin probably provide avenues for vertical movement and interchange of the ground water across the less permeable strata; however, the narrow zones of fault breccia should be avoided in selecting sites of wells because the shattered rock may require excessive casing, may involve difficult drilling, and will generally have somewhat poorer water-bearing characteristics than the parent rock.

\section{GROUND WATER}

\section{INFILTRATION AND RECHARGE}

The ground water in the Fort Rock Basin, as in most areas, is derived from the infiltration of precipitation in the area. Most of the water that percolates downward to the ground-water body passes through the permeable lavas that form the flanks of the basin. Some water also infiltrates to the ground-water body from the streams that discharge into Paulina Marsh. The amount of recharge, or replenishment, of the groundwater body varies widely from year to year, depending mostly on the total precipitation in the area. Prob- 
ably very little precipitation reaches the ground-water body during periods of below-average precipitation.

\section{DISCHARGE}

There is a continual drain on the ground-water body in the Fort Rock Basin from pumping, evapotranspiration (the combined effects of evaporation and transpiration by plants), and probably subsurface outflow beyond the area. The quantities of water discharged by each of the modes just mentioned are not known, but in order of magnitude are probably: (1) subsurface outflow, (2) evapotranspiration, and (3) pumping.

Subsurface outflow possibly occurs in two directions-to the Deschutes River drainage system and to the closed basin of Summer Lake. Additional, refined data on the surface elevations at the wells, together with available data on ground-water levels, might allow determination of the main directions of movement of ground water.

Because the water table is moderately deep throughout much of the area, the discharge of ground water by evapotranspiration is probably not large for the whole area. Evapotranspiration is greatest in the vicinities of Paulina Marsh and Silver Lake, where the water table is generally at or near the surface and where there are dense stands of water-loving plants. Evapotranspiration also may be great at Lost Forest, where perched ground water is discharged by transpiration of the pine trees.

Pumping from wells in 1960 accounted for only a relatively minor part of the discharge of ground water in the area. The amounts pumped and the potential supply available for pumping are discussed subsequently in this report.

\section{WATER-LEVEL FLUCTUATIONS}

When discharge exceeds recharge, the volume of ground water in storage decreases, and water levels in wells decline; when recharge exceeds discharge, levels rise. Thus, there is a definite relationship between the amount of precipitation and the fluctuations of the ground-water levels in the area.

Seasonal fluctuations of the water levels in wells in the area are slight and result from pumping wells or from the irrigation of fields near the wells. The major fluctuations of water levels are due to the long-term trends in precipitation.

The long-term fluctuations of ground-water levels in a large part, if not all, of the Fort Rock Basin for the period 1932-60 are in general represented by the levels measured in well $27 / 15-4 \mathrm{G} 1$. The well is drilled 257 feet deep and 16 to 8 inches in diameter and taps the basalt(?) of the Fort Rock Formation. The hydro- graph of the well is shown on figure 8 together with graphs of the annual precipitation and cumulative departure from a long-term average near Fremont.

A comparison of the hydrograph of well $27 / 15-4 \mathrm{G} 1$ and the graph of the cumulative departure shows that the long-term water-level fluctuations apparently lag about 10 years behind the long-term precipitation trend. Levels in nine other wells in the area measured for various intervals during the period 1932-60 show the same general long-term trend. As the hydrograph in figure 8 shows, the water level at the end of 1960 may have been near the end of a long-term rise or at the beginning of a period of general decline.

\section{CHEMICAL QUALITY OF THE GROUND WATER}

The chemical quality of the ground water in the Fort Rock Basin, as determined by analyses of nine samples,
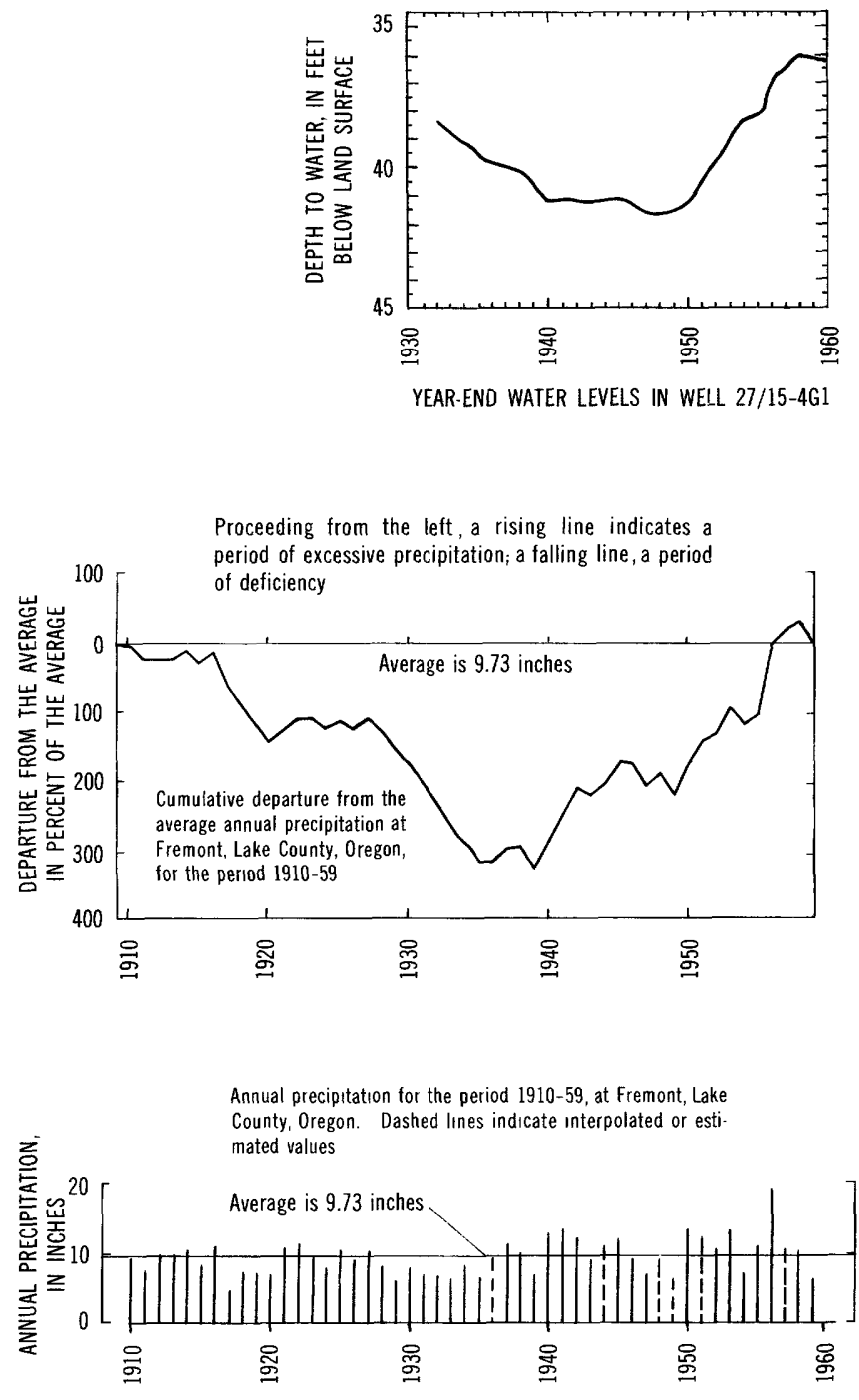

Figdre 8.-Annual precipitation and cumulative departure from the average precipitation at Fremiont, Oreg., for the period 1910-59, and hydrograph of year-end water levels in well $27 / 15-4 G 1$. 
ranged from moderately good to excellent for most purposes (table 2). Hardness of water ranged from 44 to $277 \mathrm{ppm}$ (parts per million), chloride content from 1.0 to $121 \mathrm{ppm}$, and dissolved solids from 128 to $729 \mathrm{ppm}$.

A small amount of boron is required for plant growth; however, a slightly larger amount is harmful to many plants. The water from well $26 / 15-33 \mathrm{~A} 1$ contains $2.1 \mathrm{ppm}$, the largest amount of boron in any of the samples analyzed. That amount is considered unsuitable for plants that are sensitive to boron and may be harmful to some semitolerant crops, such as small grains and potatoes (Wilcox, 1948, p. 5, and table 2), that are suited to the Fort Rock Basin. Considering the few samples analyzed, the occurrence of boron in a concentration exceeding $2 \mathrm{ppm}$ suggests that some of the more saline waters in the basin may contain even greater amounts of this constituent. Thus, any ground water that is developed for irrigation use and that is suspected of containing a substantial concentration of dissolved minerals should be tested for boron concentration.

\section{OCCURRENCE IN SUBAREAS OF THE FORT ROCK BASIN}

The principal aquifers, or water-bearing rock units, and their water-yielding character have been discussed briefly in the preceding section on "Geology." The most productive are the basaltic flow rocks and the coarse-grained pyroclastic rocks. Because the number, position, and extent of these aquifers varies widely from place to place in the Fort Rock Basin, a better understanding of the hydrologic conditions in specific subareas can be obtained if these subareas are discussed separately.

The part of the Fort Rock Basin that includes most of the arable land has been separated into eight subareas in this report. These subareas, whose locations are shown on figure 9, are herein designated as follows: Hager Mountain slope, Paulina Marsh subarea, Thorne Lake subarea, Seven Mile Ridge subarea, Lost Forest subarea, Fort Rock-Christmas Lake Valley, Hayes Butte slope, and Horse Ranch subarea.

The principal development of ground water in the Fort Rock-Christmas Lake Valley, the Seven Mile

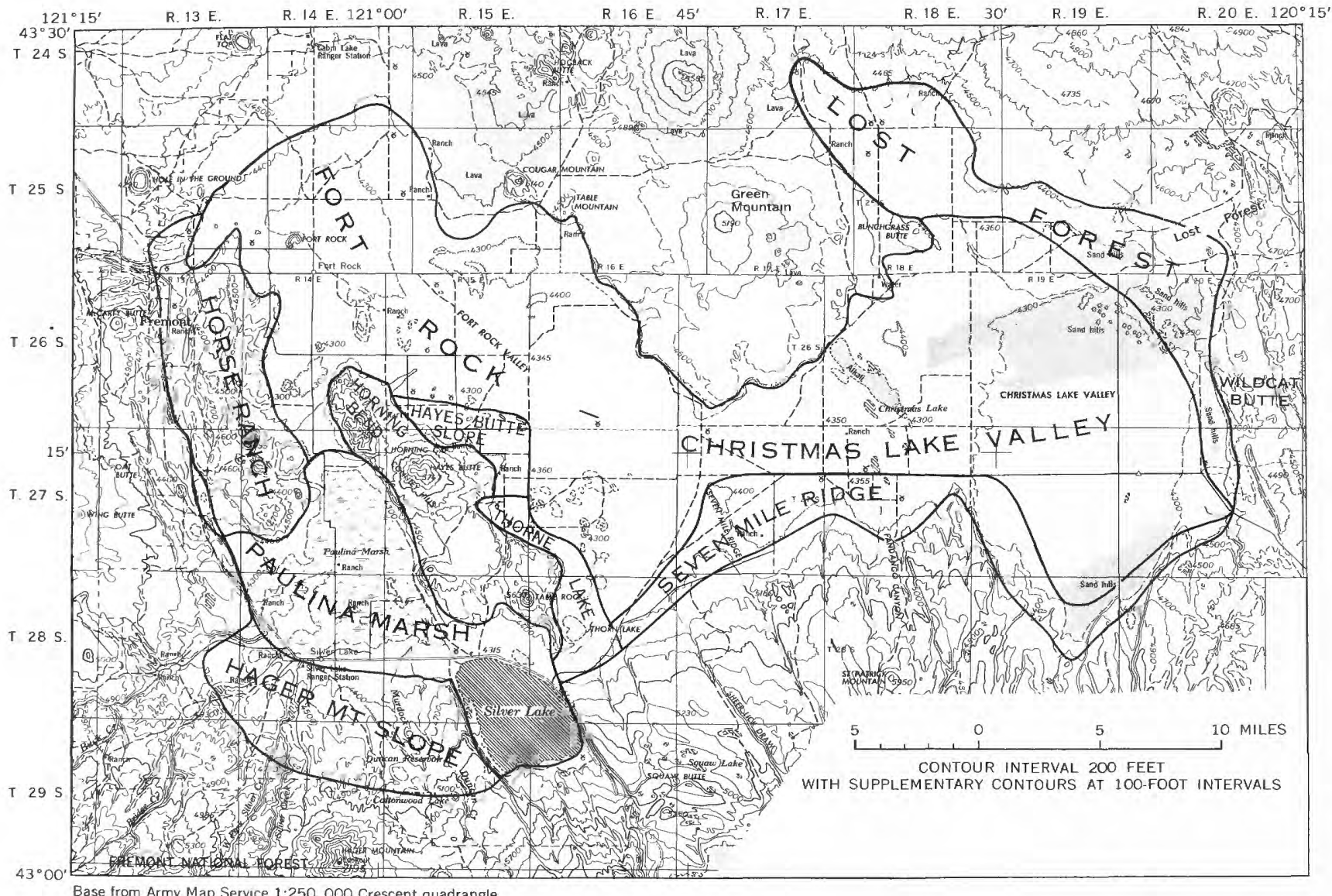

Frgure 9.-Map of Fort Rock Basin, showing principal ground-water subareas. 
Ridge subarea, the Thorne Lake subarea, and the Hayes Butte slope is for irrigation. Two ranches in the Paulina Marsh subarea also are irrigated from wells (fig. 10). The occurrence of ground water in the subareas that are presently developed and the potential aquifers that are probably present in the other subareas are described below.

\section{HAGER MOUNTAIN SLOPE}

The region between Buck Creek, the southern and western edges of Silver Lake, the southern edge of the valley plain of Paulina Marsh, and the steep slopes of Hager Mountain is included in the subarea called Hager Mountain slope. The geologic units underlying this subarea are the Picture Rock Basalt, Fort Rock Formation, Hayes Butte Basalt, and unconsolidated delta deposits and alluvium. Of these, the Picture Rock Basalt and the unconsolidated deposits have yielded water to wells. Because most of the tillable land in this subarea is irrigated by surface water, only a few attempts have been made to obtain supplies of ground water adequate for irrigation. Most of the domestic water supplies in this subarea are obtained from shallow dug or drilled wells or from springs.
A record is available from only one deep well (28/14-27L1) in the subarea. This well was drilled to a total depth of 480 feet (table 1 ). The driller reported that this well penetrated basalt (Picture Rock Basalt) from 24 to 480 feet below the land surface. As this well was drilled, the static water level stood about 55 or 60 feet below the land surface until a depth of 150 feet was reached. At the 150 -foot depth, the static level dropped to 89 feet below the land surface. The yield of this well at a depth of 143 feet was about $30 \mathrm{gpm}$ (gallons per minute); its yield at the final depth was not determined.

The shallow wells in this subarea seldom exceed 50 feet in depth. They obtain perched water from the Quaternary alluvium of upland meadows or stream valleys. The yields of these wells are small because the aquifers supplying them are not extensive nor very productive.

The Picture Rock Basalt, which passes beneath the lowland at the north side of this subarea, where the only tillable land occurs, is probably the best potential source of ground water for irrigation in this subarea. At other places, the Picture Rock yields large quantities of water to wells.

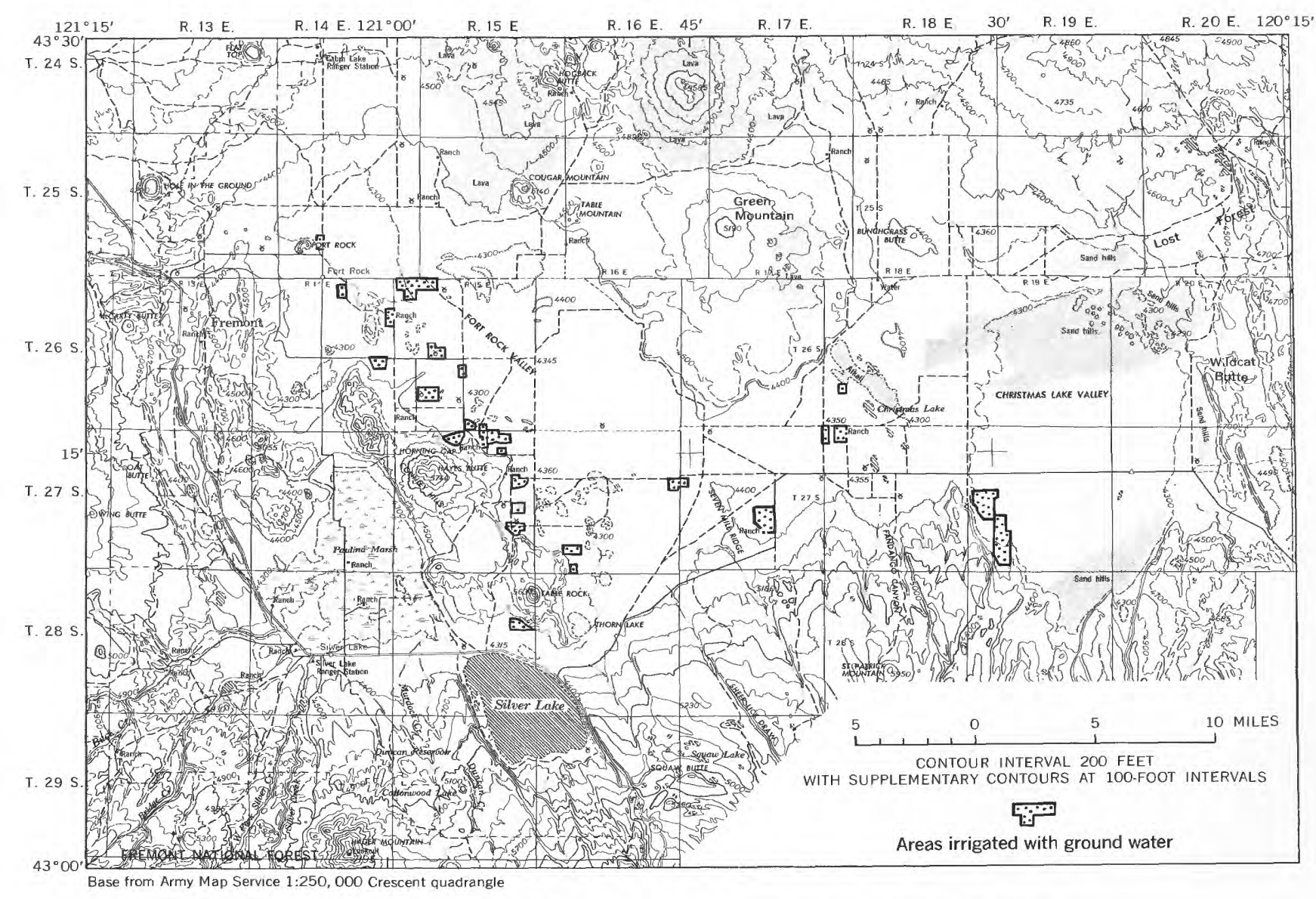

Figure 10.-Map of Fort Rock Basin, showing areas irrigated from wells in 1960 . 
Because few wells have been drilled in this subarea, the water-yielding character of the Fort Rock Formation and Hayes Butte Basalt have not been tested. If the Hayes Butte Basalt extends below the water table and is penetrated by wells, it might also yield moderate to large quantities of water. The Fort Rock Formation is probably either absent, occurs above the water table, or is too thin to yield appreciable amounts of water to wells in this subarea.

In this subarea, as in other parts of the Fort Rock Basin, the altitude at which any rock unit or aquifer may be struck during drilling varies considerably from place to place, owing to the initial dips or subsequent folding of the rock units and to displacement by faulting.

\section{PaULINA MARSh SUbarea}

The part of the Fort Rock Basin occupied by Silver Lake, Paulina Marsh, and adjacent low-lying areas is included in the Paulina Marsh subarea. This subarea is underlain by unconsolidated alluvial and delta deposits, Hayes Butte Basalt, materials of the Fort Rock Formation, and Picture Rock Basalt.

The delta deposits, Fort Rock Formation, and Picture Rock Basalt have been tapped by wells. Most of the wells have been dug or drilled to shallow depths into the delta deposits or Fort Rock Formation and yield quantities of water adequate only for domestic and stock supply. Several irrigation wells tap the Fort Rock Formation and Picture Rock Basalt at places where surface water is not available for irrigation.

Well 28/15-14H1 is representative of irrigation wells drilled into the Picture Rock Basalt. The driller's log shows that the basalt was entered at a depth of 452 feet (alt $3,923 \mathrm{ft}$ ) and penetrated to a depth of 520 feet. The yield of this well is reportedly more than $1,000 \mathrm{gpm}$ with only a few feet of drawdown.

In well $28 / 15-14 Q 1$, which is about half a mile south of well 28/15-14H1, Picture Rock Basalt was entered at a depth of 613 feet (alt $3,702 \mathrm{ft}$ ), or at an altitude 221 feet lower than that of well $28 / 15-14 \mathrm{H} 1$. This evidence indicates the large variation in depth of the water-bearing units within relatively short distances and suggests a vertical displacement of more than 200 feet between the two wells.

Well 28/14-21Q2 is representative of some of the wells that tap the Fort Rock Formation. The driller's $\log$ of this well shows that the Fort Rock Formation was entered at a depth of 18 feet and that several beds of cinders and gravel, any of which may be potential water-yielding zones, occur at depths ranging from 145 to 240 feet below the land surface. This well yielded $154 \mathrm{gpm}$ with 11 feet of drawdown after 4 hours of pumping, and its water is reportedly free of sand. Un- like most wells, either shallow or deep, that were drilled into the alluvium and the Fort Rock Formation in the Paulina Marsh subarea and near Silver Lake, this well has a factory-perforated liner in the interval from 180 to 240 feet below the surface. The slots in the liner are machine cut, $1 / 8 \times 1 \frac{1}{2}$ inches in size and, like a well screen, hold back the larger size loose materials in the aquifer while allowing the ground water to enter the well.

\section{THORNE LAKE SUBAREA}

An irregular, elongate lowland area extending north from Silver Lake and lying east and north of Table Rock is herein designated the Thorne Lake subarea (fig. 9).

The geologic units underlying this subarea are unconsolidated deposits, materials of the Fort Rock Formation, and Picture Rock Basalt. The principal water-yielding units in the subarea are the Fort Rock Formation and Picture Rock Basalt. As indicated on plate 1, the Picture Rock Basalt along the southern border of the subarea dips beneath the unconsolidated deposits and Fort Rock Formation at angles ranging from $1^{\circ}$ to $4^{\circ}$. The Picture Rock Basalt is cut by the northwestward-trending faults whose vertical displacements range from a few to more than 200 feet. Thus, the depth to the Picture Rock Basalt at any particular place in the Thorne Lake subarea is contingent upon the dip of the basalt, the distance from the outcropping basalt, and the amount and direction of vertical movement on the particular fault block that underlies that place. The logs of some wells in the subarea show a sharp difference in the depth to basalt for wells drilled a quarter of a mile apart and thus indicate the continuation of faults in the Picture Rock Basalt at depth.

The Fort Rock beds in this subarea consist of diatomite and tightly to moderately consolidated tuffs. In the part of this subarea adjacent to Table Rock (an eruptive center for the Fort Rock Formation), the sedimentary and pyroclastic materials of the Fort Rock Formation are generally poorly sorted, tightly cemented, and poorly permeable. The driller's log of well $28 / 16-$ 5Q1 (table 1) shows the diversity of the materials in that part of the subarea and indicates that the depth to the Picture Rock Basalt is 718 feet. The static water level in that well was 43 feet below the land surface when the well was 608 feet deep, and 29 feet when the well was completed at a 764-foot depth. The well is reported to yield $140 \mathrm{gpm}$; no record of the drawdown at this pumping rate is available.

Well $27 / 16-34 \mathrm{~L} 1$, about 3 miles northeast of well 28/16-5Q1, penetrated a thick section of diatomite before entering the Picture Rock Basalt at a depth of 675 feet. A comparison of the driller's log of that well with 
the $\log$ of well $28 / 16-5 Q 1$ shows the typical increase in the proportions of diatomite and other fine-grained material in the Fort Rock Formation with distance from the Fort Rock eruptive centers.

Wells finished in the Fort Rock Formation that underlies the southern part of the Thorne Lake subarea yield small to moderate quantities of water, but none drilled to date (1960) are considered adequate for irrigation supplies.

\section{SEVEN MILE RIDGE SUBAREA}

The part of the area that extends generally from the Thorne Lake subarea to the eastern edge of the basin and which includes Seven Mile Ridge, the lower slope of Picture Rock Ridge, and some of the lowland near the southem edge of Christmas Lake Valley is herein called the Seven Mile Ridge subarea (fig. 9). The geologic units underlying this subarea are unconsolidated deposits, in the Fort Rock Formation, and the Picture Rock Basalt.

The aquifers tapped by wells in this subarea are the Fort Rock Formation and Picture Rock Basalt. As in the Thorne Lake subarea, the depth to the water-yielding Picture Rock Basalt at any place in this subarea depends on the distance from the outcropping basalt, the dip of the basalt, and the amount and direction of vertical displacement on individual fault blocks within the basalt.

The Picture Rock Basalt in Seven Mile Ridge subarea is found at shallower depths than in the Thorne Lake subarea and is generally highly permeable.

The driller's log of well 27/17-27L1 shows the Picture Rock Basalt to be overlain by 60 feet of soil and materials of the Fort Rock Formation. The basalt was penetrated to a depth of 195 feet, at which depth the drill bit reportedly dropped into a 25 -foot-deep cavern (probably a lava tube). This well yielded 4,800 gpm with 40 feet of drawdown and 2,500 gpm with 13 feet of drawdown, from the Picture Rock Basalt.

Several shallower wells have been dug or drilled into the Fort Rock Formation and furnish moderate quantities of water. Well $27 / 17-13 \mathrm{~A} 1$ penetrated alternating beds of diatomite and sand of this formation to a depth of 116 feet and yielded $30 \mathrm{gpm}$ with 20 feet of drawdown after 3 hours of pumping.

Several wells in the eastern part of the Seven Mile Ridge subarea near Viewpoint Ranch have been tested at about $2,500 \mathrm{gpm}$ with drawdown ranging from 4 to 15 feet. Well $27 / 19-19 \mathrm{G} 1$, which obtains its water from the Picture Rock Basalt, is typical of these wells.

\section{LOST FOREST SUBAREA}

The northeastern and eastern border areas of the Fort Rock Basin constitute the Lost Forest subarea (fig 9). This subarea ranges in width from about $1 \frac{1}{2}$ miles at Buffalo Wells to about 5 miles near Peters Creek sink (pl. 1).

The principal aquifers of this subarea are dune sand, Paulina Basalt, Hayes Butte Basalt, and Fort Rock Formation. These units have been tapped by wells and have yielded some water. Wells in the southern part of this subarea tap materials of the Fort Rock Formation, those in the northwestern part tap the dune sand and possibly the Hayes Butte Basalt, and those in the northwestern part tap the Paulina Basalt.

One of the few wells in the subarea that was intended for irrigation supply is well $25 / 18-5 \mathrm{C} 1$. This well taps the Paulina Basalt and was reported to yield about 400 gpm, a quantity considered inadequate by the owner. The driller reported that the water was "lost" when the well was drilled to a depth of nearly 200 feet; the well was then plugged with cement to a depth of 115 feet. The water level in that well is not known, but static levels in two other wells about three-quarters of a mile west of well $25 / 18-5 \mathrm{C} 1$ and at about the same altitude stood at about 50 feet below the land surface in October 1948.

No logs of the wells in the southern part of this subarea are available, but records of water levels are. The water level in several wells in the Buffalo Wells area (pl. 1) stood about 35 feet below the level of the valley plain in October 1948.

\section{FORT ROCK-CHRISTMAS LAKE VALLEY}

The Fort Rock-Christmas Lake Valley constitutes the largest subarea in the Fort Rock Basin. This subarea is a flat, nearly featureless plain, extends eastward about 40 miles from near Fort Rock, and ranges in width from 4 to about 12 miles.

The two principal aquifers in this subarea are the Paulina Basalt, which at places underlies and elsewhere forms the northern border of the subarea, and the Fort Rock Formation, which underlies the greatest part of the subarea. The Picture Rock Basalt underlies the area at depth, and is tapped by at least one well.

The aquifers of the Fort Rock Formation occur throughout the subarea and consist largely of basaltic and pumice sand, basaltic agglomerate, and lava flows. Well 27/18-6F1, which penetrated mostly beds of sand, gravel, and tuff, and a thick layer of diatomite, is representative of wells drilled into the Fort Rock Formation in the central Christmas Lake Valley. That well reportedly yielded $375 \mathrm{gpm}$ with 45 feet of drawdown after 8 hours of pumping.

Well 27/18-12A1, about 6 miles east of well $-6 \mathrm{~F} 1$, was drilled through the Fort Rock Formation and into the Picture Rock Basalt (table 1). This well yielded 
1,300 $\mathrm{gpm}$ with 54 feet of drawdown after 4 hours of pumping.

Wells in the Fort Rock Valley have penetrated and obtained water from several thin lava flows within the Fort Rock Formation, as shown in the driller's log of well $26 / 15-5 \mathrm{C} 1$. This well reportedly yielded 2,000 gpm with 25 feet of drawdown after 2 hours of pumping.

Well 26/15-6C2, about three-fourths of a mile west of well $26 / 15-5 \mathrm{C} 1$, is another large-yield well that taps the Fort Rock Formation. This well apparently penetrated nearly the same sequence of materials as well $26 / 15-5 \mathrm{C} 1$ and reportedly yielded $1,000 \mathrm{gpm}$ with 27 feet of drawdown after 8 hours of pumping.

\section{HAYES BUTTE SLOPE}

The lower slopes on the northeast, side of Hayes Butte constitute the subarea herein called the Hayes Butte slope. The subarea is an L-shaped strip about 7 miles long and $11 / 2^{-2}$ miles wide and includes about 15 square miles.

The principal aquifers in the area are agglomerate, cinder, and basalt flows of the Fort Rock Formation. The Hayes Butte Basalt is at the surface at the southern and western borders of this subarea, and underlies part of the subarea at shallow depths beneath unconsolidated deposits. The Fort Rock Formation occurs at depth and is tapped by wells scattered throughout the subarea.

Well 27/15-2P1 is representative of wells that have been drilled through the Hayes Butte Basalt and obtain water from the Fort Rock Formation. This well is 79 feet deep, and was tested at a yield of $1,250 \mathrm{gpm}$ with a drawdown of 3 feet after 1 hour of pumping. Well 27/15-11R2, another large-yield well, about 1 mile southeast of $27 / 15-2 \mathrm{P} 1$, penetrated unconsolidated deposits, the Hayes Butte Basalt, and the Fort Rock Formation to a total depth of about 90 feet. It obtains water from cinder beds of the Fort Rock Formation.

\section{HORSE RANCH SUBAREA}

The part of the Fort Rock Basin south of Hole-inthe-Ground, west of the Fort Rock Valley floor, generally east of State Highway 31, and north of Paulina Marsh is called the Horse Ranch subarea. This subarea is characterized by fault-block uplands, small eruptive centers, and small closed basins. The tracts of arable land in this region are relatively small, and no irrigation wells were known to exist as of 1960 . The principal aquifers in the subarea-the Hayes Butte Basalt and the Fort Rock Formation-are tapped only by domestic and stock wells.

Wells $26 / 13-4 \mathrm{~B} 1$ and $26 / 13-15 \mathrm{H} 1$ are representative of those wells in the subarea that obtain water from the Hayes Butte Basalt (table 1). Well 26/13-25R1 was drilled through the Hayes Butte Basalt and obtains its water from the Fort Rock Formation. No data are available on the yields of these or other wells in this subarea; therefore, the water-yielding character of the local aquifers is unknown.

\section{POTENTIAL FOR ADDITIONAL DEVELOPMENT}

Because of the lack of perennial surface-water supplies in most of the area, any additional water supplies that are developed in the Fort Rock Basin must come largely from ground-water sources. By far the greatest demand for ground water, in the future as at present, will be for irrigation. However, substantial increases in the use of ground water for irrigation would probably be accompanied by some increase in demands for domestic and stock supplies.

A.s is indicated by figure 10, only about 6,000 acres of the land within the Fort Rock Basin was irrigated with water from wells in 1960 . The discussions of the subareas included descriptions of most of the more productive irrigation wells in the subareas as of 1960, and three of the subareas had no wells used for irrigation supply. However, a few wells intended for irrigation supply have been drilled in the area each year during this investigation, and prospecting for ground water for irrigation is expected to continue in the future.

The water levels in wells tapping the more productive aquifers are not greatly affected by the present-day pumping withdrawals but apparently fluctuate chiefly in response to long-term changes in recharge from precipitation (fig. 8). The failure of the pumpage to cause a noticeable general decline in ground-water levels indicates that only a sinall part of the total ground water available for withdrawal is currently being used.

In a brief report appraising the ground-water supplies available for irrigation in the area, Newcomb $(1953$, p. 5) estimated that the recharge from precipitation was about 125,000 acre-feet per year. He further estimated that 50,000 acre-feet of ground water was transpired by vegetation, leaving about 75,000 acre-feet to discharge from the basin by other means, principally by subsurface outflow. The 75,000 acre-feet could be considered as the maximum increment of the average annual recharge that is available to supply water pumped for irrigation or other purposes. The amount of water pumped during 1960 is estimated to be only 12,000 acre-feet.

The aforementioned estimates indicate that roughly one-tenth of the ground water that is replenished naturally each year was pumped during 1960 and that as much as 60,000 acre-feet of additional water could be pumped annually without overdraft of the ground-water supplies if the subsurface outflow could be salvaged completely. Moreover, the amount pumped might be 
increased if part of the evapotranspiration could be salvaged for beneficial use. Thus, at the 1960 rate of development, the amount of additional ground water that is available for withdrawal in the basin will probably exceed the demand for many years. However, any plans for the large-scale withdrawal of additional ground water from the area should provide for spacing of the wells to minimize interference (mutual drawdown) among the wells. In addition, periodic measurements of ground-water levels should be continued to provide early warning of overdraft that may develop in the future.

All the subareas are underlain by aquifers that will yield quantities of water adequate for substantial irrigation supplies. In some, such as in parts of the Thorne Lake subarea, the most productive aquifers occur at depths greater than 1,000 feet; thus, construction and development of wells capable of yielding quantities of water adequate for irrigation at those places would be costly. In other subareas, such as the Fort RockChristmas Lake Valley, wells require proper construction and development to obtain optimum yields of sandfree water.

The local occurrence of ground water containing greater amounts of dissolved minerals than are desirable for some purposes (p. B19) indicates that the chemical quality, as well as the quantity, may be critical in the future development of additional ground-water supplies in the Fort Rock Basin.

\section{WELL CONSTRUCTION}

Most of the wells in the Fort Rock Basin have been drilled with percussion (cable-tool or churn) drills, although a few have been dug, driven, or bored. The older wells usually have only a few feet of casing, regardless of the materials penetrated. As a result, some of the wells that obtain water directly from sand or that pass through sand and tap agglomerate or basalt aquifers yield large amounts of sand with the water. The sand causes undue wear on pump parts and clogs sprinklers and transmission pipes. Although some of the newer wells have enough casing to prevent to a large extent the "quicksand" layers from sloughing into the well, some sand is produced from the uncased water-yielding part of the wells. One well is cased with a machine-perforated liner in the water-bearing sand and grit zone; this liner not only effectively prevents sloughing of the aquifer materials into the well but permits free passage of water into the well.

Several moderately high yield wells in the basin have been abandoned for irrigation use because of excessive sand. Those wells probably could have been developed into adequate sand-free irrigation wells if a properly sized screen or perforated liner had been installed in the aquifer material, and the wells had then been adequately developed. The size of the openings in the screen or perforations in the liner is selected on the basis of grain-size analyses of the aquifer sand, sampled during drilling. After the screen or perforated liner is installed, the well is developed, usually by surging or by intermittent pumping at a high rate. During proper developing, most of the fine-grained material adjacent to the well comes through the openings into the well and thus is removed, leaving a natural pack around the casing before the well is put into use. Adequate development of a well having screen or perforated liner not only eliminates or materially reduces the entrance of sand later, but also improves the yield of the well by increasing the permeability of the aquifer materials adjacent to the well.

TABLE 1.-Drillers' logs of selected wells in the Fort Rock Basin, Lake County, Oreg.

Data collected from drillers or owners, or from reports submitted to the State Engineer. Altitudes determined approximately by barometric leveling. All depths given in feet below land surface at well. Tentative stratigraphic designation are by the author.

\begin{tabular}{l|l|l}
\hline Materials & $\begin{array}{c}\text { Thickness } \\
\text { (feet) }\end{array}$ & $\begin{array}{c}\text { Depth } \\
\text { (feet) }\end{array}$ \\
\hline
\end{tabular}

Well 25/18-5C1

[ZX Ranch. Alt 4,400 ft. Drilled by Frank Skillings, 1959. Depth $115 \mathrm{ft}$; 18-in. casing to $8 \mathrm{ft}$. Pumped $400 \mathrm{gpm}$ ]

\begin{tabular}{l|r|r}
\hline Clay, sandy & 5 & 5 \\
Paulina Basalt: & 63 & 68 \\
Basalt__. red. & 4 & 72 \\
Cinders, red. & 43 & 115 \\
Basalt__.
\end{tabular}

Well 26/13-4B1

[Sam Olmstead. Alt 4,488 ft. Dug by W, E. McCallum and owner, 1910 and 1932 Depth $220 \mathrm{ft}$; 3 -in. casing to $198 \mathrm{ft}$; static water level $201 \mathrm{ft}, 1932]$

Peyerl Tuff:

Gravel.

Clay, red, bricklike (tuff?)

Rock fragments, loose

Basalt(?) _.

Pumice tuff(?)

Tuff.

Hayes Butte Basalt:

Basalt, porous, fractured.

\begin{tabular}{l|r} 
& \\
10 & 10 \\
50 & 60 \\
15 & 75 \\
30 & 105 \\
15 & 120 \\
40 & 160 \\
60 & 220 \\
\hline
\end{tabular}

Well 26/13-15H

[U.S. Soil Conservation Service. Alt 4,480 ft. Dug by W. L. Dehne, 1914. Depth $200 \mathrm{ft}$; 48 -in. casing; static water level $184 \mathrm{ft}, 1914]$

\begin{tabular}{|c|c|c|}
\hline $\begin{array}{l}\text { Soil } \\
\text { Peyerl Tuff: } \\
\text { Basalt(?) } \\
\text { Diatomite. } \\
\text { Pumice tuff, tuffaceous, contains basaltic } \\
\text { Sandstone, } \\
\text { lapilli. } \\
\text { Hayes Butte Basalt: } \\
\text { Basalt. }\end{array}$ & $\begin{array}{r}8 \\
8 \\
30 \\
30 \\
104 \\
20\end{array}$ & $\begin{array}{r}180 \\
200\end{array}$ \\
\hline
\end{tabular}


TABLE 1.-Drillers' logs of selected wells in the Fort Rock Basin, Lake County, Oreg.-Continued

Materials

\begin{tabular}{|c|c|}
$\underset{\text { Thickness }}{\text { (feet) }}$ & $\begin{array}{c}\text { Depth } \\
\text { (feet) }\end{array}$
\end{tabular}

\section{Well 26/13-25R}

[W. J. Mattis. Alt 4,460 ft. Drilled by Sam Olmstead, 1940. Depth $180 \mathrm{ft}$; 6-in casing to $60 \mathrm{ft}$ and 4-in. casing to $180 \mathrm{ft}$; static water level $160 \mathrm{ft}$, 1940]

Hayes Butte Basalt:

Boulders (weathered basalt)

Basalt, black

Fort Rock Formation:

Tuff, yellow

Agglomerate, basaltic

Tuff, red and gray.

\section{Well 26/15-5C1}

[Ed Turner. Alt 4,315 ft. Drilled by Frank Skillings, 1957. Depth $361 \mathrm{ft}$; 12-in. casing to $123 \mathrm{ft}$; static water level $32 \mathrm{ft}$, Apr. 23, 1957. Pumped 2,000 gpm for $2 \mathrm{hr}$., drawdown $25 \mathrm{ft}$ ]

Fort Rock Formation:

Clay, sandy

Sand, fine.

Clay, gray (diatomite?)

Clay, gray (diatomite?)

Clay, yellow (tufte)

Clay, gray, dark (ashy diatomite?)

Clay, black, rotten

Rock, gray, hard (welded tuff?)

Clay, brown (tuff?)

Lava

Clay, brown (tuff?)

Lava . . . . . .

Rock, gray, hard (lava?)

Lava, porous

Rock, gray

\begin{tabular}{rr|r}
\hline & \\
& 28 & 28 \\
4 & 32 \\
11 & 43 \\
- & 5 & 48 \\
14 & 62 \\
66 & 128 \\
18 & 146 \\
3 & 149 \\
27 & 176 \\
64 & 240 \\
20 & 260 \\
- & 12 & 272 \\
15 & 287 \\
- & 31 & 308 \\
- & 38 & 356 \\
- & 361 \\
- & & \\
\hline
\end{tabular}

\section{Well 26/15-6C2}

[A. E. Albertsen. Alt 4,310 ft. Drilled by Claude Shafer, 1956. Depth $317 \mathrm{ft}$; 16 -in. casing to $36 \mathrm{ft}$ and 12-in. casing to $119 \mathrm{ft}$. Pumped $1,000 \mathrm{gpm}$ for $8 \mathrm{hr}$, drawdown $27 \mathrm{ft}$ ]

Soil.

Fort Rock Formation:

Gravel, pea-size.

Silt, sandy

-

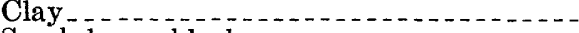

Sand, loose, black

Clay

Sand, loose, black .....................

Clay - _-_...-_

Sand, black, with clay (cinder tuff)

Sandstone, hard (tuff?)

Tuff. ............

Tuff, sand layers

Tuff.

Lava and "sand"

Tuff._.

Lava.....

Tuff

Gravel; streaks of sand and clay
TABLE 1.-Drillers' logs of selected wells in the Fort Rock Basin, Lake County, Oreg.-Continued

\begin{tabular}{|c|c|c|}
\hline Materials & $\underset{\text { (feet) }}{\text { Thickness }}$ & $\begin{array}{l}\text { Depth } \\
\text { (feet) }\end{array}$ \\
\hline \multicolumn{3}{|l|}{ Well 27/15-2P1 } \\
\hline \multicolumn{3}{|c|}{$\begin{array}{l}\text { [Edwin Eskalin. Alt 4,320 ft. Drilled by owner, 1935. Depth 79 ft; } 12 \text {-in. casing } \\
\text { to } 12 \mathrm{ft} \text { s static water level } 27.1 \mathrm{ft} \text {, Oct. } 25,1948 \text {. Pumped 1,250 gpm for } 1 \mathrm{hr} \text {, draw- } \\
\text { down } 3 \mathrm{ft} \text { f] }\end{array}$} \\
\hline Unconsolidated deposits: & & \\
\hline $\begin{array}{l}\text { Soil, sandy } \\
\text { Sandstone, gray, medium-grained (hard- }\end{array}$ & 6 & \\
\hline $\begin{array}{l}\text { pan?) } \\
\text { pante, gray, medum-graine }\end{array}$ & 6 & 1 \\
\hline Hayes Butte Basalt: & & \\
\hline $\begin{array}{l}\text { Basal } \\
\text { Fort Rock }\end{array}$ & 15 & 2 \\
\hline $\begin{array}{l}\text { ort Rock F } \\
\text { Pumice, }\end{array}$ & 18 & \\
\hline low & 29 & \\
\hline Cinders, black & 5 & 79 \\
\hline
\end{tabular}

Well 27/15-11R2

[Jess Miles. Alt 4,350 ft. Drilled by Edwin Eskalin, 1947. Depth $90.5 \mathrm{ft}$; 12-in. casing to $9 \mathrm{ft}$; static water level $46.5 \mathrm{ft}$, Oct. 21,1948$]$

Soil, sandy

Unconsolidated deposits:

Gravel, sandy

Hayes Butte Basalt:

Lava, red, porous

Fort Rock Formation:

Cinders, red, and black gravel........

Ash, white, "packed"

Cinders, red...

Gravel, cemented

Gravel, coarse, rounded, and sand

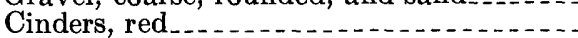

Lava, porous, red (welded tuff?)

Cinders, red, and gravel ..........

Gravel, coarse, loose

\begin{tabular}{l|l}
2.5 & 2.5
\end{tabular}

6

8. 5

38

46. 5

25. $5 \quad 72$

\begin{tabular}{l|l}
.5 & 72.5
\end{tabular}

$3 \quad 75.5$

\begin{tabular}{l|l}
.5 & 76 \\
2 & 78
\end{tabular}

$6 \quad 84$

$3 \quad 87$

5

Well 27/16-34L1

[Mallett estate. Alt 4,330 ft. Drilled by Floyd Nicholson, 1957. Depth $828 \mathrm{ft}$; 12-in. casing to $10 \mathrm{ft}$; static water level $24 \mathrm{ft}, 1957$. Pumped $400 \mathrm{gpm}$ for $2 \mathrm{hr}$, drawdown $97 \mathrm{ft}$ ]

Soil.

"Hardpan" (caliche in soil?)

Fort Rock Formation:

Diatomaceous earth

Sand, gray, water-bearing; yield 5 gpm; static water level $70 \mathrm{ft}$

Diatomacous earth

Picture Rock Basalt:

Basalt, broken; static water level $47 \mathrm{ft}$ at 675-ft depth

Basalt, hard, gray; some water at $730-$ to 731-ft depth; static water level $37 \mathrm{ft} . .$.

Basalt, gray, and pumice; static water level $32 \mathrm{ft}$

Basalt, broken black; water at $782-$ to 784-ft depths; static water level $29 \mathrm{ft}$, total yield $400 \mathrm{gpm}$

Basalt, hard.

Basalt, broken; static water level $24 \mathrm{ft}$, total yield $600 \mathrm{gpm}$

Basalt, hard

\begin{tabular}{r|r}
6 & 6 \\
2 & 8 \\
282 & 290 \\
12 & 302 \\
373 & 675 \\
& \\
43 & 718 \\
46 & 764 \\
5 & 769 \\
& \\
22 & 791 \\
23 & 814 \\
6 & 820 \\
8 & 828 \\
\hline
\end{tabular}


TABLE 1.-Drillers' logs of selected wells in the Fort Rock Basin, Lake County, Oreg.-Continued

\begin{tabular}{l|l|l}
\hline Materials & $\begin{array}{c}\text { Thickness } \\
\text { (feet) }\end{array}$ & $\begin{array}{c}\text { Depth } \\
\text { (feet) }\end{array}$ \\
\hline
\end{tabular}

\section{Well 27/17-13A1}

[Jack Gillette. Alt 4,320 ft. Drilled by Floyd Nicholson, 1957. Depth $116 \mathrm{ft} ; 12$-in. casing to $18 \mathrm{ft}$; static water level $20 \mathrm{ft}, 1957$. Pumped $30 \mathrm{gpm}$ for $3 \mathrm{hr}$, drawdown $20 \mathrm{ft}]$

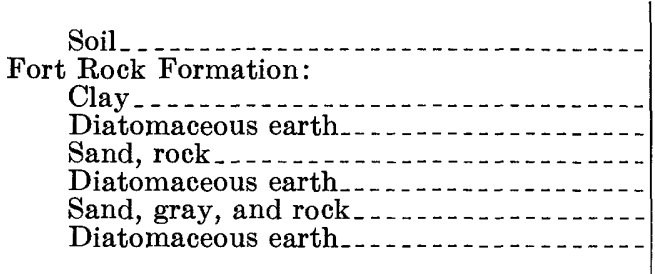

\begin{tabular}{r|r}
5 & 5 \\
2 & 7 \\
67 & 74 \\
1 & 75 \\
27 & 102 \\
10 & 112 \\
4 & 116 \\
\hline
\end{tabular}

Well 27/17-27L1

[H. Wahl. Alt 4,355 ft. Drilled by Pat McGinley, 1952. Depth $220 \mathrm{ft}$; 16-in. casing to $77 \mathrm{ft}$ : static water level $42.2 \mathrm{ft}$, June 18, 1952 . Pumped $4,800 \mathrm{gpm}$ for $6 \mathrm{hr}$, draw. down $40 \mathrm{ft}]$

Fort Rock Formation:

Soil and soft clay

Clay, hard, yellow (tuff)

Clay, blue (diatomite?)

Sand, hard, fine-grained; some water....

Picture Rock Basalt:

Rock, lava, medium-hard

Rock, lava, medium to hard......

Rock, lava, firm

Rock, lava, soft

Sand, water-bearing (cinders?)

Rock, lava, hard.

Rock, lava, soft.

Rock, lava, hard, bluish-colc

Rock, lava, soft, caving

Rock, lava, hard

Cavern (in basalt)

\begin{tabular}{r|r} 
& \\
14 & 14 \\
14 & 28 \\
20 & 48 \\
12 & 60 \\
& \\
15 & 75 \\
10 & 85 \\
45 & 130 \\
9 & 139 \\
2 & 141 \\
20 & 161 \\
10 & 171 \\
5 & 176 \\
6 & 182 \\
13 & 195 \\
25 & 220 \\
\hline
\end{tabular}

Well 27/18-6F1

[Robert Morehouse. Alt 4,320 ft. Drilled by S. Munnerlyn, 1958. Depth $425 \mathrm{ft}$; 12-in. casing to $20 \mathrm{ft}$; static water level $25 \mathrm{ft}$, June 9, 1958 . Pumped $375 \mathrm{gpm}$ for $8 \mathrm{hr}$, drawdown $45 \mathrm{ft}$.

Soil

Fort Rock Formation:

"Hardpan".

Clay, yellow (tuff?)

Clay, blue (diatong (pumice sand?) ......

Clay, blue (diatomite?)

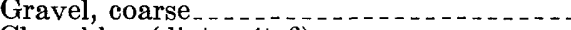

Clay, blue (diatomite?)

Gravel_.

Rock, hard, gray $-u^{-}$

Clay, blue (diatomite?)

\begin{tabular}{r|r}
5 & 5 \\
5 & 10 \\
32 & 42 \\
5 & 47 \\
33 & 80 \\
79 & 159 \\
11 & 170 \\
20 & 190 \\
10 & 200 \\
10 & 210 \\
215 & 425
\end{tabular}

\section{Well 27/18-12A1}

[J. A. Pettus. Alt 4,320 ft. Drilled by Frank Skillings, 1960. Depth $287 \mathrm{ft}$; 14-in casing to 11 is $\mathrm{ft}$; static water level $20 \mathrm{ft}$, June 1960 . Punped 1,300 gpm for $4 \mathrm{hr}$, casing to $111 / 2 \mathrm{ft} ;$

Fort Rock Formation:

Clay, sandy ....

Clay (diatomite?)

Pumice sand, water-bearing

Picture Rock Basalt:

Basalt

Cinders, gray
TABLE 1.-Drillers' logs of selected wells in the Fort Rock Basin, Lake County, Oreg.-Continued

\begin{tabular}{l|l|l}
\hline Materials & $\begin{array}{c}\text { Thickness } \\
\text { (feet) }\end{array}$ & $\begin{array}{c}\text { Depth } \\
\text { (feet) }\end{array}$ \\
\hline
\end{tabular}

\section{Well 27/19-19G1}

[View Point Ranch, Inc. Alt 4,340 ft. Drilled by Frank 6killings, 1958. Depth $314 \mathrm{ft}$; 16 -in. casing to $10 \mathrm{ft}$; static water level about $40 \mathrm{ft}$, 1959 . Pumped 2,400 gpm for $8 \mathrm{hr}$, drawdown $13 \mathrm{ft}$ ]

Unconsolidated deposits and Fort Rock Formation:

Clay, sandy

Fort Rock Formation:

Sand, coarse, pumice

Clay, sandy

Rock, gray -

Rock, lava, soft

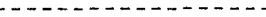

Cinders, gray (pumice)

Clay, gray

Picture Rock Basalt:

Rock, gray

Cinders, gray and red

Basalt.

Cinders

\section{Well 28/14-21Q2}

[U.S. Forest Service. Alt 4,380 ft. Drilled by R. Hartley, 1958. Depth $240 \mathrm{ft}$; 8-in. casing to $240 \mathrm{ft}$, perforated liner from 180 to $240 \mathrm{ft}$; static water level $74.5 \mathrm{ft}$, Dec. 14, 1958. Pumped $154 \mathrm{gpm}$ for $4 \mathrm{hr}$, drawdown $11 \mathrm{ft}]$

Unconsolidated deposits:

Gravel, cemented.

Fort Rock Formation:

Sandstone, brown

Chalk, blue (diatomite?)

Rock, lava, black

Chalk, blue (diatomite?)

Gravel, small.

Sandstone, red (cinders?)

Clay and cinders, sandy, red..........

Cinders, red clay, water

\begin{tabular}{r|r} 
& \\
57 & 57 \\
6 & 63 \\
19 & 82 \\
15 & 97 \\
7 & 104 \\
20 & 124 \\
6 & 130 \\
58 & 178 \\
& \\
46 & 224 \\
10 & 234 \\
50 & 284 \\
30 & 314 \\
& \\
\hline
\end{tabular}

\section{Well 28/14-27L1}

[Duane Crane. Alt 4,380 ft. Drilled by Floyd Nicholson, 1957. Depth $480 \mathrm{ft}$; 12-in. casing; static water level $89 \mathrm{ft}, 1957 \mathrm{l}$

\section{Unconsolidated deposits and Fort Rock} Formation:

Silt, sand, and rubble

Picture Rock Basalt:

Basalt, gray

Basalt, black

Basalt, black, hard, with ashy breaks

\begin{tabular}{r|r} 
& \\
18 & 18 \\
22 & 40 \\
33 & 73 \\
21 & 94 \\
51 & 145 \\
1 & 146 \\
28 & 174 \\
46 & 220 \\
20 & 240 \\
&
\end{tabular}

\section{Well 28/15-14 H1}

[A. E. Albertsen. Alt. 4,375 ft. Drilled by Pat McGinley, 1955. Depth $520 \mathrm{ft}$; i6-in. casing to $342 \mathrm{ft}$; static water level $67 \mathrm{ft}$, 1955 ]

Unconsolidated deposits:

Sand and gravel.

Hayes Butte Basalt:

Rock, lava, hard, dark

Fort Rock Formation:

Sand (lapilli tuff?) ; first water at $67 \mathrm{ft}$

Chalk, rotten (diatomite?)

Picture Rock Basalt:

Rock, lava, broke

Rock, lava, red.

Rock, lava, soft, red

Rock, lava, firm, red

Cinders, dark

Rock, lava, hard, black

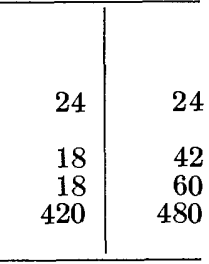

\begin{tabular}{r|r}
7 & 7 \\
21 & 28 \\
217 & 245 \\
207 & 452 \\
& \\
25 & 477 \\
18 & 495 \\
4 & 499 \\
9 & 508 \\
2 & 510 \\
10 & 520 \\
& \\
\hline
\end{tabular}


TABLE 1.-Drillers' logs of selected wells in the Fort Rock Basin, Lake County, Oreg.-Continued

\begin{tabular}{l|l|l}
\hline Materials & $\underset{\text { Thickness }}{\text { (feet) }}$ & $\begin{array}{c}\text { Depth } \\
\text { (feet) }\end{array}$ \\
\hline
\end{tabular}

Well 28/15-14Q1

[A. E. Albertsen. Alt 4,315 ft. Drilled by Frank Skillings, 1957. Depth $646 \mathrm{ft}$; 12-in. casing to $336 \mathrm{ft}$ : static water level $20 \mathrm{ft}$, Nov. 21, 1957. Pumped 1,600 gpm for $4 \mathrm{hr}$, drawdown $35 \mathrm{ft}$ ]

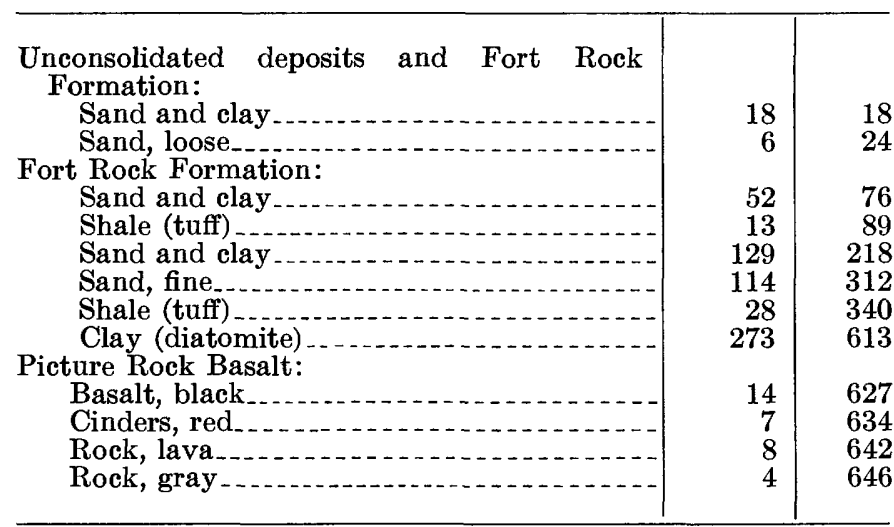

Well 28/16-5Q1

[Claude Shafer. Alt 4,320 ft. Drilled by owner, 1957. Depth $764 \mathrm{ft}$; 12-in. casing to $6 \mathrm{ft}, 12$-in. well diameter to $715 \mathrm{ft}, 8$-in. well diameter to $764 \mathrm{ft}$; static water level $29 \mathrm{ft}, 1957$. Pumped $140 \mathrm{gpm}$ ]

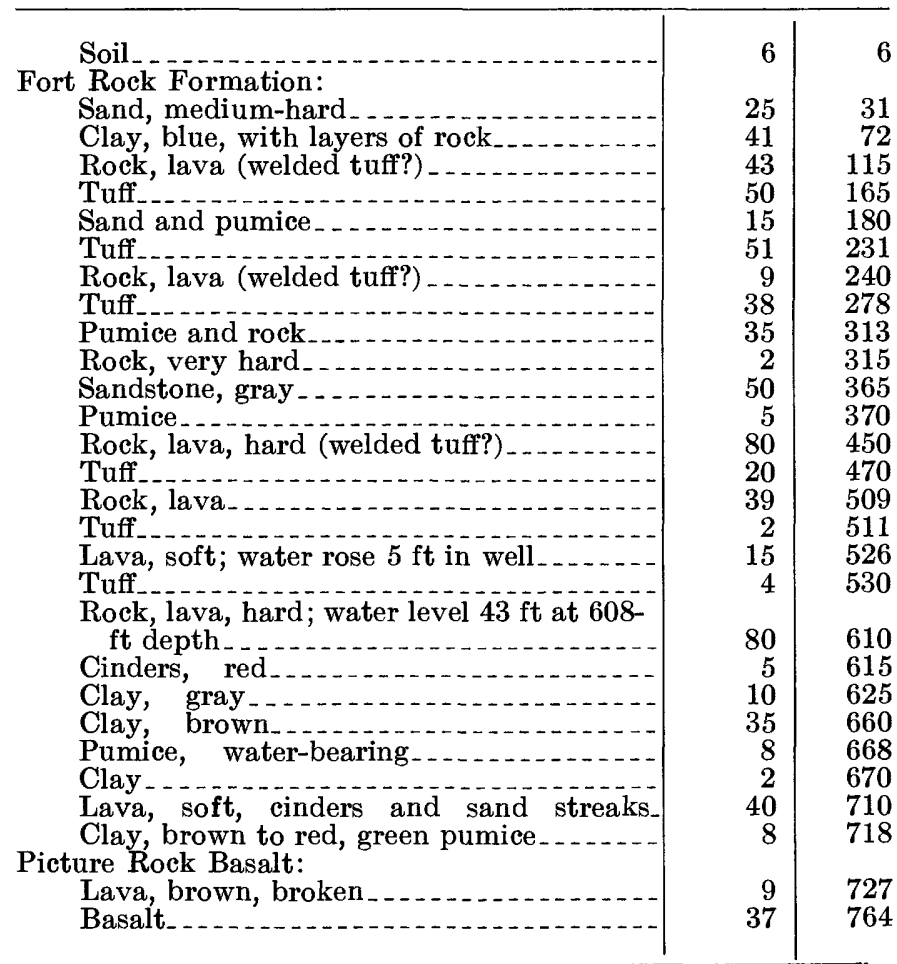




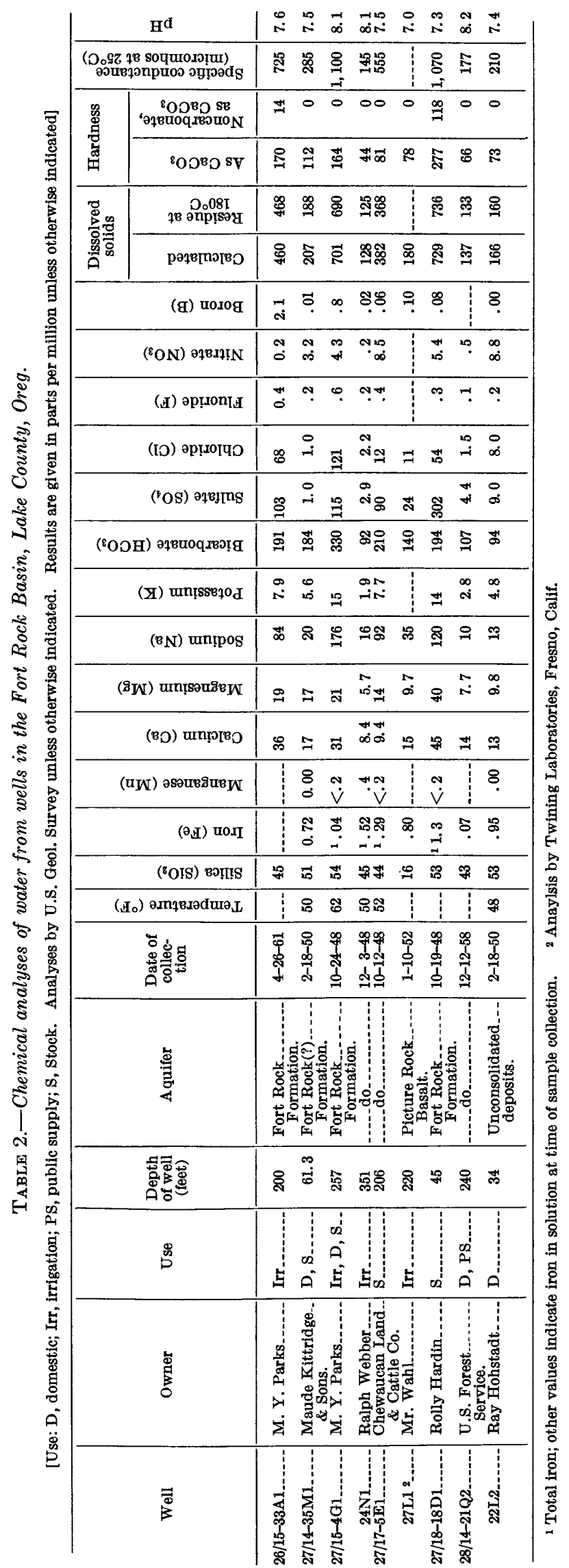




\section{REFERENCES}

Fenneman, N. M., 1931, Physiography of western United States: New York, McGraw-Hill Book Co., 534 p.

Newcomb, R. C., 1953, Ground water available for irrigation in the Fort Rock Basin, northern Lake County, Oregon: U.S. Geol. Survey open-file rept., 5 p.

1958, Yonna formation of the Klamath River basin, Oregon: Northwest Science, v. 32, no. 2, p. 41-48.

1961, Storage of ground water behind subsurface dams in the Columbia River Basalt, Washington, Oregon, Idaho: U.S. Geol. Survey Prof. Paper 383-A, 15 p., 12 figs.

Newcomb, R. C., and Hart, D. H., 1958, Preliminary report on the ground-water resources of the Klamath River basin, Oregon : U.S. Geol. Survey open-file rept., 248 p., 10 pls.

Piper, A. M., Robinson, T. W., and Park, C. F., Jr., 1939, Geology and ground-water resources of the Harney Basin, Oregon: U.S. Geol. Survey Water-Supply Paper 841, 189 p., 20 pls., 9 figs.
Russell, I. C., 1884, A geological reconnaissance in southern Oregon : U.S. Geol. Survey 4th Ann. Rept., p. 431-464.

Trauger, F. D., 1950, Basic ground-water data in Lake County, Oregon: U.S. Geol. Survey open-file rept., 287 p., 26 pls.

Waring, G. A., 1908, Geology and water resources of a portion of south-central Oregon: U.S. Geol. Survey Water-Supply Paper 220, 85 p., 10 pls., 1 fig.

Waters, A. C., 1927, A structural and petrographic study of the Glass Buttes, Lake County, Oregon: Jour. Geology, v. 35, p. 441-452, 1 fig.

Wilcox, L. V., 1948, Explanation and interpretation of analyses of irrigation waters: U.S. Dept. Agriculture Circ. 784, 8 p., 1 fig.

Williams, Howel, 1935, Newberry volcano of central Oregon: Geol. Soc. America Bull., v. 46, no. 2, p. 253-304, 8 figs. 



\section{Effect of Tectonic Structure}

on the Occurrence of

Ground Water in the Basalt

of theColumbia River Group

of The Dalles Area

Oregon and Washington

By R. C. NEWCOMB

HYD R L OGY OF V OLCANIC-ROCK TERRANES

GEOLOGICAL SURVEY PROFESSIONAL PAPER $383-\mathrm{C}$

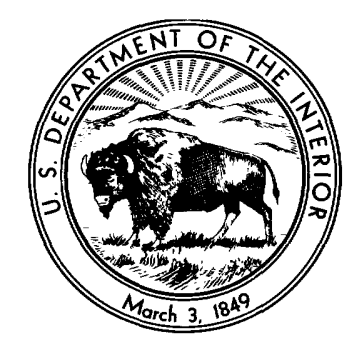

UNITED STATES GOVERNMENT PRINTING OFFICE, WASHINGTON : 1969 


\section{UNITED STATES DEPARTMENT OF THE INTERIOR \\ WALTER J. HICKEL, Secretary \\ GEOLOGIGAL SURVEY \\ William T. Pecora, Director}

For sale by the Superintendent of Documents, U.S. Government Printing Office

Washington, D.C. 20402 


\section{CONTENTS}

Abstract.

Introduction

Purpose . . . .

Physiographic setting . . .

Preceding work and schedule for this report........

Well-numbering system

General geologic setting

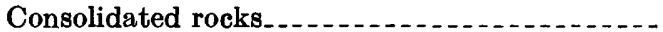

Principal bedrock units...............

Deformation and early erosion.............

Later lavas, deformation, and erosion.....

Unconsolidated rocks..........................

Geohydrology of the basalt of the Columbia River Group.

Physical and hydrologic characteristics of the rock.-

Petrologic features...............

Texture. . . . . .

Layering--.-. -

Joints produced by cooling of the lava...

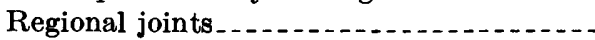

Autobrecciation

Interflow sediments

Weathering . . . . .

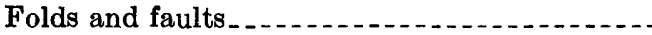

Major folds . . . . . . .

Minor folds . .

Faults
Page

C1

1

1

2

3

3

3

3

3

6

6

6

10

10

10

10

10

13

13

14

14

15

15

15

17

18
Geohydrology of the basalt-Con. Page

Ground-water occurrences_._._._._. C20

Tectonic controls on the ground water....... 20

Ease of water entry into the basalt_....... 20

Downdip, a preferential direction of groundwater movement.......................

Obstruction of percolation in aquifers. .....-

Major occurrence, beneath the main water

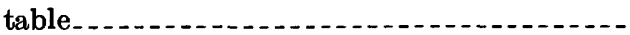

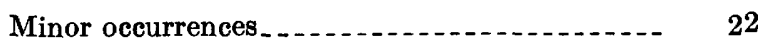

High-perched ground water.......... 22

Intermediate-perched ground water......- 22

Local examples of structural control of ground water

Mosier Creek basin

Chenoweth Creek basin.............. 25

Mill Creek valley

"The Dalles Ground Water Reservoir"...- 27

The uplands west of the canyon of the

Deschutes River................... 28

Plateau east of the Deschutes River..._. $\quad 29$

Localities north of the Columbia River.-- $\quad 30$

Summary _... 32

References cited._. 33

\section{ILLUSTRATIONS}

Plate 1. Geologic map of the Dalles area, Oregon and Washington. In pocket

Page

Figdre 1. Maps showing location of the area within the region underlain by the basalt of the Columbia River Group and the location of some principal features of the area............

2-13. Photographs showing-

2-4. Physiographic, structural, and hydrologic features.

5-7. Structural and physiographic features along the Columbia River..

8-10. Sedimentary formations......... 9-11
Figures 2-13. Photographs-Con.

11, 12. Exposures of major tectonic structures crossed by the Columbia

River..._.............. C16,17

13, 14. Erosional and structural characteristics of the basalt in the Deschutes River canyon......

15-18. Sections-

15. Along Mosier Creek ........

16. Along Mill Creek.........

17. North-south through The Dalles.---

18. Across Swale Creek valley along the northern part, and northward extension, of section $B-B^{\prime}$ (pl. 1) _. -
Page

19

24

26

29

32 


\title{
HYDROLOGY OF VOLCANIC-ROCK TERRANES
}

\section{EFFEGT OF TEGTONIC STRUCTURE ON THE OCGURRENGE OF GROUND WATER IN THE BASALT OF THE COLUMBIA RIVER GROUP OF THE DALLES AREA, OREGON AND WASHINGTON}

\author{
By R. C. Newcomb
}

\section{ABSTRACT}

The 620-square-mile area studied lies across the boundary of the Cascade Range and Columbia Plateaus and affords geologic and hydrologic conditions typical of the basalt region.

The basalt of the Columbia River Group is the oldest rock exposed. More than 2,000 feet of accordantly layered lava underlies the area shown on the White Salmon, The Dalles, and Wishram quadrangle maps, and is at the surface in about half of the area. The overlying Pliocene Dalles Formation remains mostly in the two largest synclines. Its thickness reaches a maximum of about 2,000 feet, but beneath wide areas it is about 500 feet. Post-Dalles lavas and Pleistocene fluvial deposits in places cover the older rocks.

The rubbly tops of some of the lava flows and the brecciated flows within the sequence form aquifers that yield large to small amounts of water to wells and springs. The yield of the aquifers depends on the hydrologic conditions and structural situation.

The main tectonic structural features branch from the Cascade Range. They are the Bingen anticline and Colvmbia Hills anticlinorium and the accompanying Mosier and Jalles synclines. The folds and faults partly control the levels at which ground water occurs.

The natural channel of the Columbia River was graded between low falls and rapids. The Deschutes River is largely graded and the Klickitat River partly graded. The other streams are small and descend to river level through canyoned reaches cut in the basalt; some of the smaller tributaries are cut into or through the Dalles Formation in the broader upland parts of their valleys. Most of the stream valleys follow synclines and are consequent upon the tectonic structures; principal exceptions are at the Bingen and Rowena Gaps where the Columbia River crosses the major anticlines.

Ground water in the basalt aquifers occurs mainly under three situations: (1) beneath the regional, or main, water table near river level, (2) perched at intermediate altitude near baseleveled secondary streams, and (3) perched at high levels near the top of the basalt in the uplands.

Tectonic structure affects ground-water conditions in the basalt by the inclination of the aquifers, by formation of barriers to lateral percolation, by creation of avenues for some vertical movement, and by production of inlets for recharge and outlets for discharge.

The inclination of aquifers increases the opportunity for infiltration and vertical transfer, and also for lateral and vertical percolation along the permeable interflow zones.
The structural barriers to lateral percolation occur where the underlying impermeable strata rise in an anticline, where faults destroy or offset the permeable layers, or where combinations of faults and folds interrupt the aquifers. Together with stratigraphic discontinuities, the structural barriers have caused the impoundment of ground water in the basalt above the main water table. The levels of the outlets around barriers determine the uppermost level to which the obstructed ground water rises.

Ground-water is impounded behind a sheared anticline in Mosier Creek valley, upslope from a fault in Mill Creek valley, and behind a fault across Swale Creek valley. Two other such impoundments of ground water lie behind an anticlinal bulge across three creek valleys near Jap Hollow and isolated by a complex combination of fault and fold barriers that bound "The Dalles Ground Water Reservoir." These impoundments result in ground water occurring at levels many hundreds of feet above the ground-water level in nearby areas of structurally undisturbed basalt.

The discharge of ground water at springs is sufficiently controlled by structural elements that the interpretative process can be reversed; hydrologic features can indicate the geologic structure. For example, in places on long dip slopes, transverse synclines can be indicated by concentrations of springs and transverse courses of streams.

The close relation between the tectonic structure and the occurrence of ground water in the basalt can be used to make better predictions of drilling results. The structural criteria for ground-water storage can be projected elsewhere in the basalt region.

An accurate map of the geology, and particularly of the geologic structures, has been found imperative to the interpretation of the ground-water occurrences.

\section{INTRODUCTION PURPOSE}

The narrowing margin between the amount of water we use and the nearly fixed amount of the total natural supply makes necessary more and better information on all facets of our water situation. The ground water and the space in which water could be stored beneath the land surface are partly neglected resources that are available to meet some of our expanding needs for water. 
Preliminary observations on the ground-water characteristics of the widespread basalt of the Columbia River Group (Newcomb, 1959) are tested and refined by closer examination in the present study of a type area. By map and text, this report combines pertinent information on geology and hydrology to determine what we can deduce about the water-storage situations created by the tectonic structures. Among other applications, the lessons learned are to be used in a companion study of the water-storage facilities created by the tectonic structures in the region of 55,000 square miles underlain by the basalt in Washington, Oregon, and Idaho (fig. 1).

\section{PHYSIOGRAPHIC SETTING}

The area lies in the west-central part of the basalt region. It consists of about 620 square miles in a rectangle, 45 minutes of longitude by 15 minutes of latitude, shown on the White Salmon, The Dalles, and Wishram quadrangle maps, scale 1: 62,500. (See fig. 1 and pl. 1.) The area extends from the Cascade Range
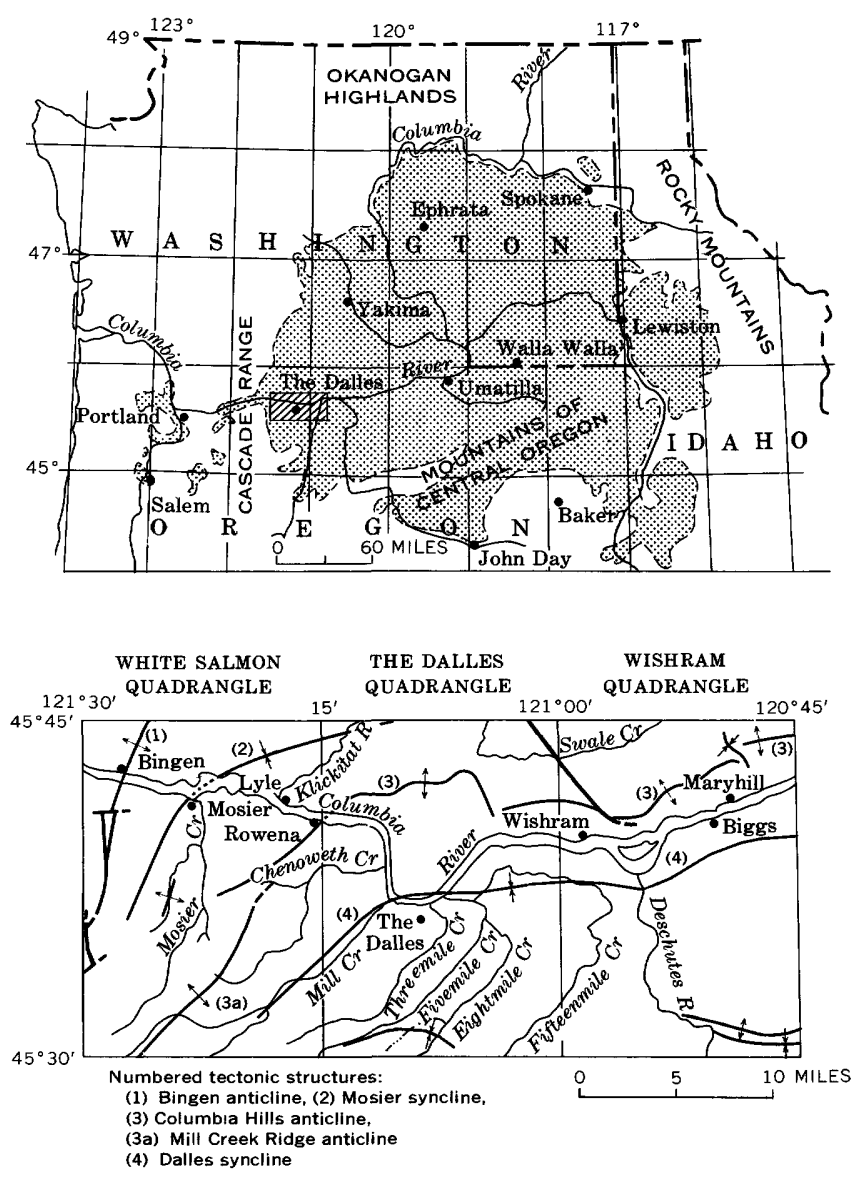

Figdre 1.-Location of the area (ruled) within the region underlain by the basalt of the Columbia River Group (stippled) and the location of some principal features of the area. eastward beyond the canyon of the Deschutes River, well out into the Columbia Plateaus physiographic province (Fenneman, 1931). The main topographic feature is the westward-trending gorge of the Columbia River, which transects the area (figs. $3,5,12$ ).

Rock exposures, petrologic characteristics of the basalt, physiography, and climate in the area are representative of the whole region (Newcomb, 1959, pl. 1) underlain by the basalt of the Columbia River Group, but the tectonic deformation is a little greater than average.

The area includes a great variety of physiographic features and tectonic structures. Landforms range from level, gently rolling plateaus to steep canyons and mountains. The degree of deformation ranges from none to that resulting in overturned and crushed basalt. The cover mantling the basalt varies in thickness and character from none through shallow and deep soil to sedimentary and volcanic deposits which in places are many hundreds of feet thick.

The climate ranges from humid in the highest parts at the west side of the area, where 35-40 inches of precipitation falls annually, to semiarid in the lowest altitudes at the east side, where only 8-10 inches is received.

In a large sense, the area is plateau greatly diversified by broad extensive slopes and low mountain ranges, and subdivided by gorges and canyons. Much of the southern half consists of separate parts of one plateau that slopes northward to the east-west ridge known as the Columbia Hills. Where this plateau once intersected the toe of the Columbia Hills uplift, the Columbia River entrenched a canyon that is 800 feet deep east of Rowena Gap. The Deschutes River, in a youthful canyon (fig. 14), flows down the slope of that plateau.

The physiography of the western part of the area is dominated by broad ridges and valleys which are part of the Cascade Range. These include the ridge called Sevenmile Hill in Oregon and the Columbia Hills in Washington, the Hood River Mountain-Burdoin Mountain ridge, and the intervening lowland in which the Klickitat River and Mosier Creek enter the Columbia River. The deepest segments of the river canyons, known as Rowena and Bingen Gaps, have been cut by the Columbia River through the two ridges mentioned above. (See figs. 2, 11.) Starting at Rowena Gap, the river's canyon through the Cascade Range is known by the term the "Columbia Gorge."

The natural channel of the Columbia River was largely graded between widely separated falls and rapids, where the deepest of its multiple channels were irregularly entrenched along joint and other fracture planes in the descent over the edge of particularly mas- 
sive layers of the basalt. The falls at Celilo, where the total descent was about 50 feet, were the greatest of the falls. These falls are now submerged in the reservoir behind the Dalles Dam. The Deschutes River (fig. 14) is largely graded to the Columbia River level, but the Klickitat River is only partly graded; it descends in places over the more coarsely jointed layers of basalt in narrow channels entrenched along joint planes (fig. 4).

In addition to the major physiographic units, important minor elements include an edge of the Hood River Valley in the Cascade Range at the west side and most of Swale Creek Valley in the part of the Columbia Plateaus lying to the north of the Columbia Hills.

\section{PRECEDING WORK AND SCHEDULE FOR THIS REPORT}

Previous work on geology and hydrology in the area consists largely of that described in a water-supply paper by A. M. Piper (1932). A map of the locality of the Dalles Dam was available from Sargent's (1956) work. The McDermid Cone had been shown to be a Quaternary volcanic vent, and the young lava near Haystack Butte had been mentioned by Hodge $(1932 ; 1942$, p. 29-30).

The fall of 1962 , the summer and fall of 1963 , and the first half of 1964 were spent in fieldwork and drafting of the map and illustrations. Most of the groundwater data were contributed by well drillers, and other data were collected by the office of the Oregon State Engineer, the Water Resources Division of the Washington Department of Conservation, and the district offices of the Water Resources Division of the U.S. Geological Survey.

\section{WELL-NUMBERING SYSTEM}

The wells used for reference data in this report are numbered according to the rectangular system of land division. The first two numbers of the full well symbol refer to the township and range, the third denotes the section and is followed by a letter that indicates the 40-acre tract. The one-sixteenth tracts are lettered alternately and successively westward and eastward in horizontal tiers starting with $\mathrm{A}$ in the $\mathrm{NE} 1 / 4 \mathrm{NE} 1 / 4$ and ending with $\mathrm{R}$ in the southeast cormer; the letters $\mathrm{I}$ and $\mathrm{O}$ are omitted. The last figure is a serial number of the wells in that 40-acre tract. Thus, well $1 \mathrm{~N} / 12-28 \mathrm{Q} 1$ is the first well recorded in the SW1/4 SE $1 / 4$ sec. $28, \mathrm{~T} .1 \mathrm{~N}$., R. $12 \mathrm{E}$. The full well number is used in a few places for full clarity; the post-hyphen part giving the section, tract, and serial number, such as $30 \mathrm{~N} 1$, is used generally in the text; only the letter and serial number are given on the map.

\section{GENERAL GEOLOGIC SETTING}

CONSOLIDATED ROCKS

PRINCIPAL BEDROCK UNITS

The thick sequence of accordantly layered lava flows of Miocene and Pliocene age is the oldest rock exposed and comprises the main bedrock of the arean (pl. 1). This unit in its entirety is shown as the basalt of the Columbia River Group. The total thickness of the rock unit exceeds the 2,000 feet of layered strata exposed in Rowena and Bingen Gaps. Much of the top thousand feet of it is well exposed in many places along the Columbia River (figs. $3,5,7)$. This thick sequence of lava rock is the main water-bearing unit of the area.

Overlying the basalt is a thin to thick deposit of fragmental volcanic debris and sedimentary materials, called the Dalles Formation. The deposition of the Dalles Formation started with little time delay after the end of the basalt outflows. The age determinations on the Dalles Formation have generally agreed with the early Pliocene age first assigned by Buwalda and Moore (1930), but extensions of the sedimentary facies toward slightly younger deposits on the east indicate that part of the sedimentary facies may have been deposited as late as the middle Pliocene (Newcomb, 1966).

The formation consists of two facies-a volcanic-sedimentary deposit of effusive debris and a sedimentary deposit. One facies is centered in a former fan of waterlaid and airborne grayish-tan volcanic debris from sources to the southwest. The other facies comprises the remnants of a sedimentary train that was laid down to the, east and around the north edge of the debris fan. The two facies interfinger in a broad zone which follows the lower part of Fifteenmile Creek and passes near The Dalles. Locally, the formation is known by such common terms as "sandstone," "chalk," or "conglomerate." Its total stratigraphic thickness is about 1,800 feet near Upper Mill Creek in the southwest part of the area, where the formation is all fragmentary debris of volcanic origin. The total thickness decreases to the east and north; it is about 450 feet near the Deschutes River and about 160 feet at the east edge of the area, where only the sedimentary facies is present. On the north side of the Columbia River, the thickness exceeds a hundred feet in only a few places, and the formation consists largely of the sedimentary deposit.

The diameter of the particles in the volcanic effusive deposit decreases to the east and north, as does also the percentage of the included andesite clasts (fig. 8). Eastward from Fifteenmile Creek, the sedimentary deposit predominates and layers of water-laid pebble and cobble conglomerate become a progressively larger part of the 


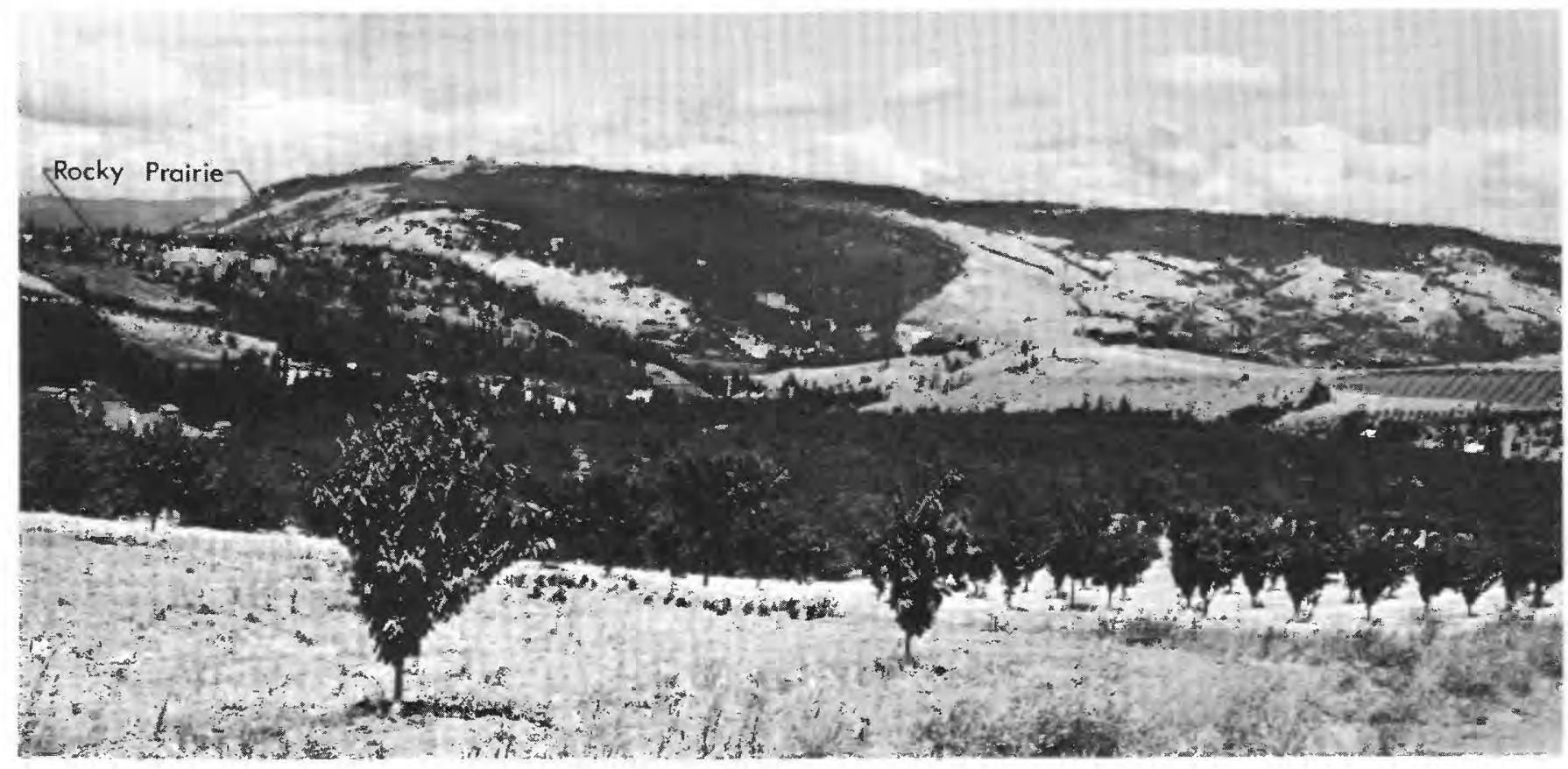

Figurw 2.-View north down the lower part of the Mosier Creek valley, domed form of Bingen anticline making Burdoin Mountain in the background. Axis of the narrow Rocky Prairie anticline continues east across center ground. The orchards in the middle ground are mostly on Quaternary Iakebeds within the Orchard syncline. The foreground is an erosional slope on the Dalles Formation.

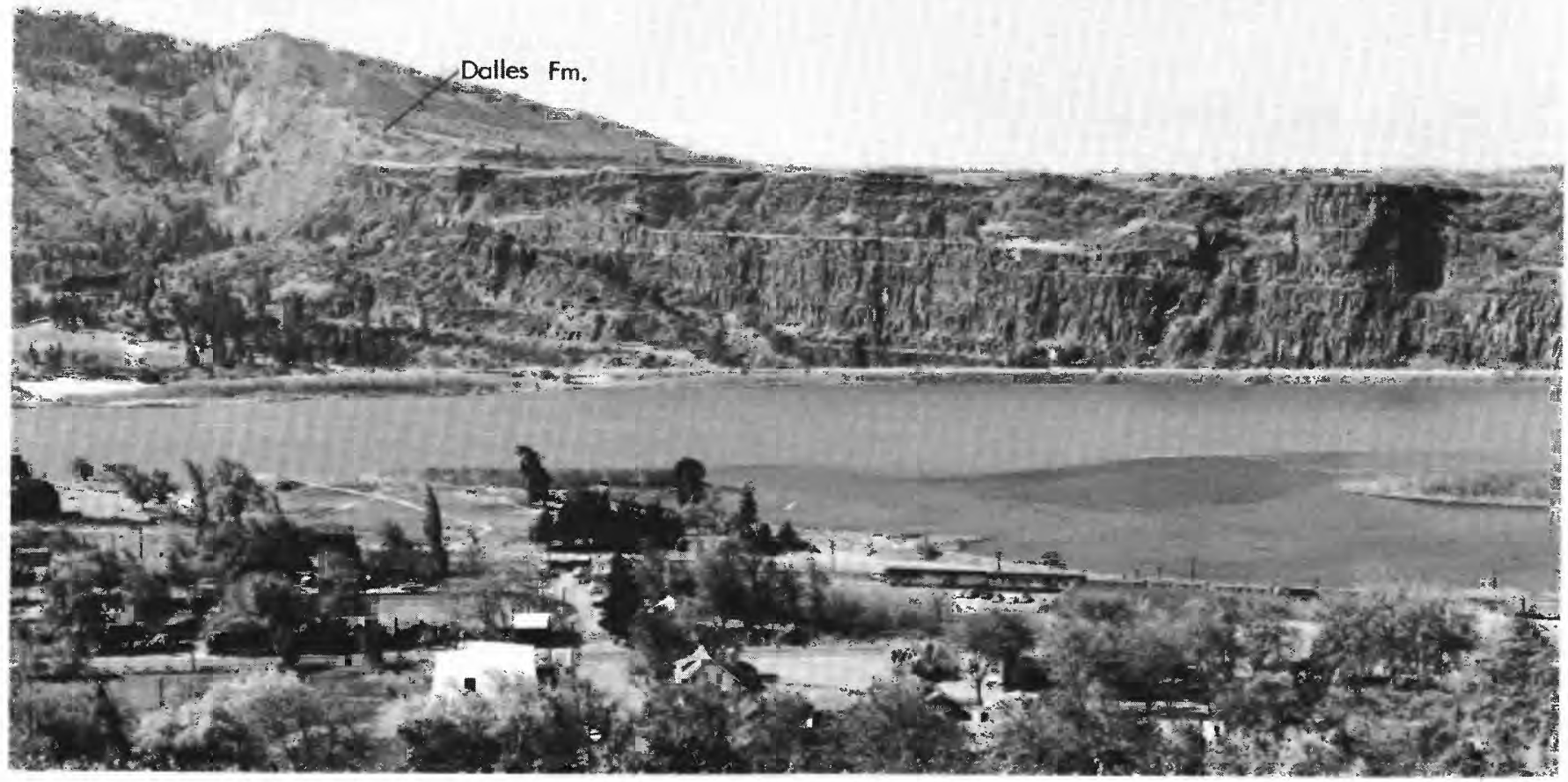

Frgone 3.-View southwest from Lyle across the river toward basalt escarpment of Rowena Point. Sharp upturn of the strata in left background is part of Ortley segment of Columbia Hills anticline and its westward branch to the Rocky Prairie anticline. 


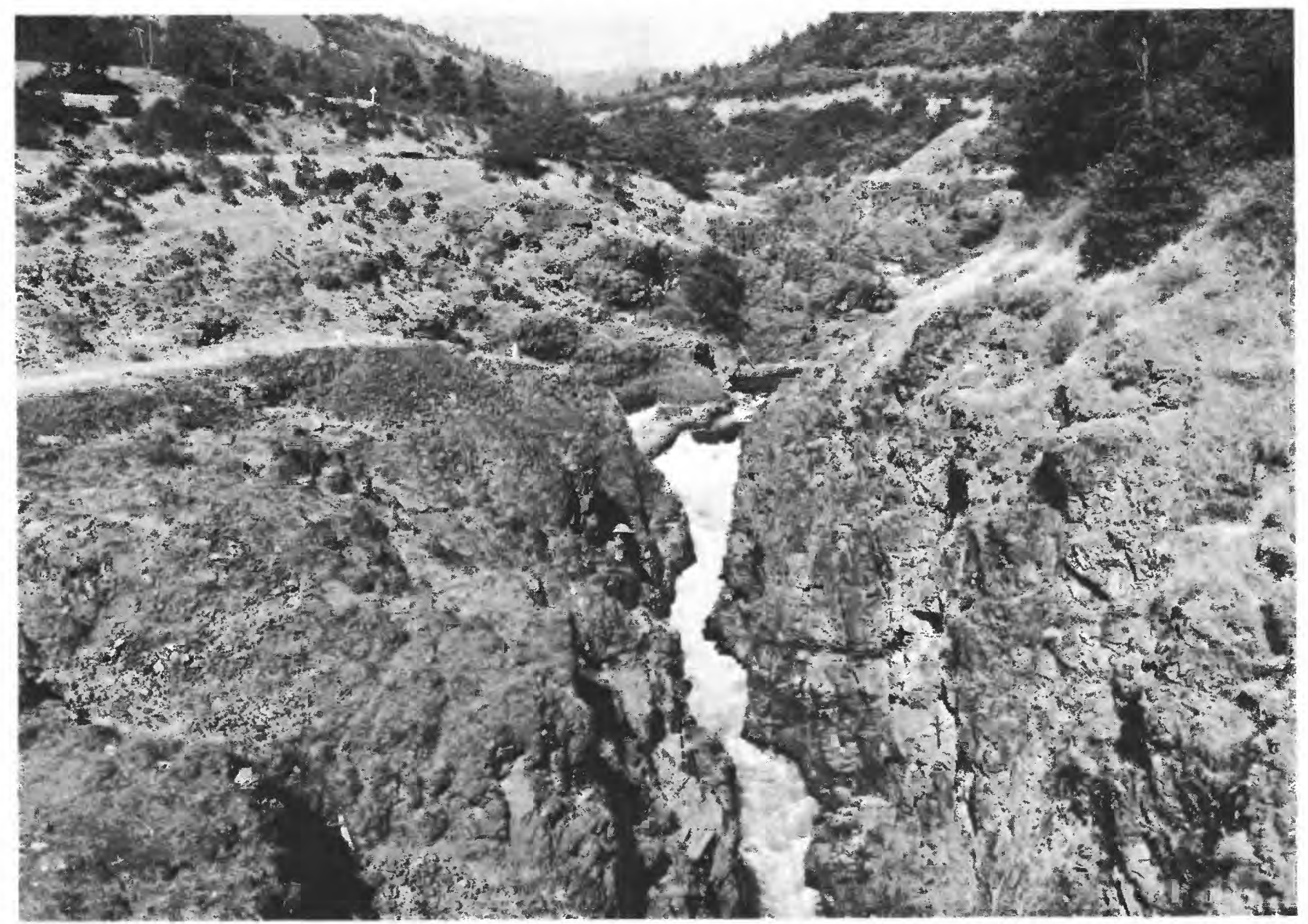

Frgure 4.-View northward up the Klickitat River canyon in the narrow dell being cut through a particularly massive basalt flow just above the mouth of Silvies Creek (SE $1 / 4$ sec. 26, T. 3 N., R. 12 E.). Some concrete flumes along the river assist migratory flsh around the most difficult of the rapids.

deposit. This conglomerate forms about half the 100 to 200 -foot thickness of the formation east of the Deschutes River. The conglomerates consist mostly of westward- and northwestward-transported stream-rounded pebbles and cobbles of dense andesitic and basaltic rocks, silicified volcanic rocks, and basalt similar to the basalt of the Columbia River Group. No quartzite or metamorphics of the type common to the northern Rocky Mountain region were seen in the conglomerates.

One 50-foot-thick flow of basaltic lava occurs within the formation and forms an erosion-retarding rim around the upland between Fifteenmile Creek valley and the adjacent river canyons.

As described by Piper (1932, p. 125), the erosional relief on the basalt beneath the Dalles Formation is small and, at most places, the basal beds of the Dalles Formation are parallel to the top flows of the basalt.
This conformity can be observed in the lower part of Chenoweth Creek valley northwest of The Dalles, on Mill Creek Ridge, on Hood River Mountain, in a highway cut 3 miles northwest of Lyle, and in many other places. However, in a few places, small angular discordance is present and erosional unconformities exist. Drilling records also indicate that erosional unconformities occur at places. The top of the basalt is slightly weathered beneath the Dalles Formation in exposures near the mouth of Badger Creek in the lower Chenoweth Creek valley and in the west side of Signal Hill east of The Dalles, but the top of the hard and resistant basalt in ravines 3 miles west of Lyle is fresh and unaltered.

Overlying the Dalles Formation and the basalt of the Columbia River Group southeast of Hood River is a basalt porphyry which dips west into the Hood River 
Valley along the flank of Bingen anticline, where it seems to have sustained at least part of the deformation of the post-Dalles folding. A different basalt porphyry caps the Dalles Formation in the Balch Lake area northwest of Lyle, where its single flow has been warped in the Mosier syncline.

\section{DEFORMATION AND EARLY EROSION}

Minor deformations were beginning during late Miocene or early Pliocene time, and major deformations occurred in middle or late Pliocene and in early or middle Pleistocene time.

Some mild warpings were taking place while the top part of the basalt of the Columbia River Group was being extruded. Evidences of these mild deformations are: (1) the many layers of pillow lava, which indicate frequent ponding of drainage, in the uppermost 500 feet of the basalt in the Dalles syncline; (2) the lack of eastward extension of the thick flows at the top of the basalt in the Mosier area, which shows that an ancestral high on the east may have limited the top flows; and (3) an apparent pre-Dalles(?) age of a fault in the Mill Creek valley (fig. 16).

After the deposition of the Dalles Formation, extensive warping took place along the lines of the present major structures. Erosion had beveled strata of the Dalles Formation (pl. 1) to form the "Mount Hood Flat erosion surface," which Piper (1932, p. 141) tentatively correlated with Buwalda's (1929) early or middle Pliocene "Ochoco erosion surface," before the deposition of the volcanic rocks of High Cascades started in late(?) Pliocene time.

LATER LAVAS, DEFORMATION, AND EROSION

Part of the erosion surface preserved in Mount Hood Flat, which is centered 5 miles southwest of The Dalles, was covered by flows of olivine-bearing andesitic basalt. It is the type of rock mapped as "volcanic rocks of High Cascades" by Callaghan and Buddington (1938, pl. 1) and commonly called the "Cascade lava." The outflow of lava of this group took place over a relatively long time, in late(?) Pliocene, Pleistocene, and Recent time. The lava extrusions continued long enough that some postdated the large uplifts of middle Pleistocene and even some of the following erosion; late lavas moved down canyons which had been cut several hundred feet below the Mount Hood Flat erosion surface.

The olivine-bearing basalt of the intracanyon lavas at White Salmon is probably the youngest large extru- sion of the Cascade-lava epoch in this area. Farther east, the smaller extrusions of lava and effusive materials at McDermid Cone and Haystack Butte (fig. 7) belong to the prominent area of "Simcoe lava" north of this map area and appear to be as young as the lavas near White Salmon.

A second major deformation resulting in regional uplift started in early or middle Pleistocene time; the rocks that were deformed included the early parts of the volcanic rocks of High Cascades. The regional uplift set the conditions for the erosion of the great canyons and gorges. This deformation and uplift may have occurred in several stages, but the large river canyons had been cut virtually to their present form by late Pleistocene time, when melt water from the Wisconsin (Flint, 1937, p. 222) continental glacier flowed down the Columbia River. (See figs. 5-7.)

\section{UNCONSOLIDATED ROCKS}

Unconsolidated sedimentary deposits of Tertiary (?) and Quaternary age include gravel, sand, and silt laid down by the Columbia River when it flowed at its present general level, but also when, at times, it was swollen by glacial melt water and when it was impounded to great depth during the last of the glacial stages of Pleistocene time. Glaciofluvial gravel occurs mainly on rock benches below altitudes of 600 feet, but some lies at higher levels, where currents along the shores reworked local materials, presumably during the Lake Lewis episode. (See fig. 9.) Deposits of silt, sand, and clay are preserved mostly in protected side valleys, where they were laid down in proglacial Lake Lewis. The dam which could have impounded such a lake was thought by Russell (1893, p. 25-29) to have been caused by a mountain glacier; Allison (1933, p. 719) reported the evidence indicated that the dam was due to ice jams, lava, or landslides and that the dam started accumulating in the gorge west of Hood River, which is just west of this area.

Fine-grained lacustrine deposits underlie the valley plain in places as high as altitudes of 800 feet in the Hood River Valley, where they are among the materials grouped as undifferentiated alluvium, and to about 820 feet in Mosier Creek valley. They are of little significance in Mill Creek valley, where they occur as high as about 600 feet. In the eastern part of the area they may have been extensively removed or reworked by the wind. The former existence of proglacial Lake Lewis is indicated by erratics, shorelines (fig. 7), and lakebed deposits, all of which have been extensively described 


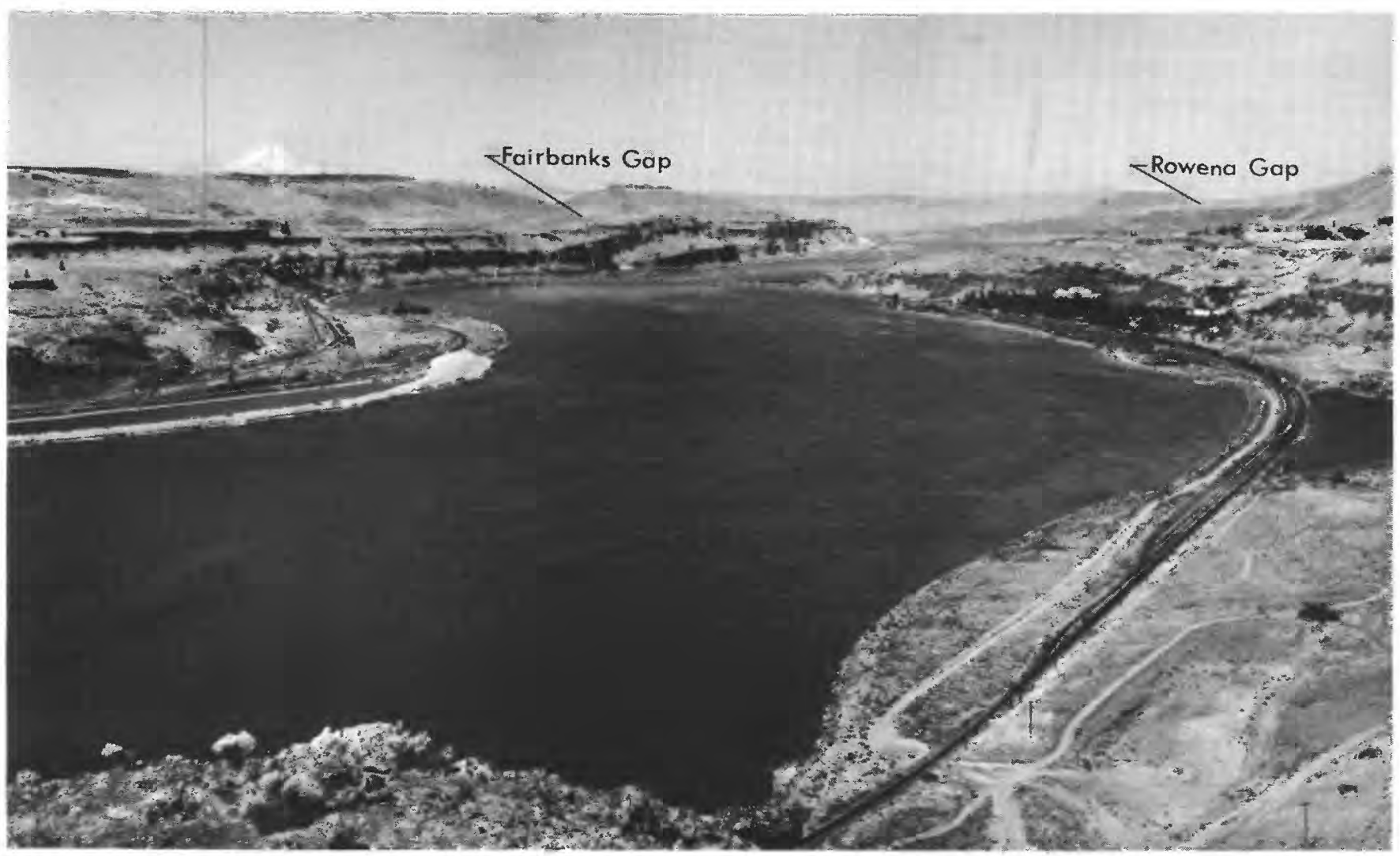

Figdre 5.-View west down the Columbia River over Wishram (in trees on right bank) and the Celilo Bridge. A mile-long ramp of basalt dips $2^{\circ}$ upstream from Fairbanks Gap. The rimrock at the top of the south side of the gorge is formed by the porphyritic basalt flow in the Dalles Formation. The top of the basalt of the Columbia River Group is about 50 feet above the floor of Fairbanks Gap.

for southern Washington and north-central Oregon (Allison, 1933). Allison's general maximum level of 1,150 feet for the occurrence of erratics farther east is $50-150$ feet higher than the maximum level to which the writer found similar features in this area. The locations of a few of the large granitic erratics observed by the writer at altitudes above 800 feet are shown on plate 1 .

The depositional and erosional features leit by the proglacial Lake Lewis have had an outstanding effect on the economic potential of the area. Soil and overburden were scoured from the slopes along the Columbia River to a general altitude of a thousand feet at The Dalles. Gaps into side valleys, like those to Fifteenmile Creek near Fairbanks and Petersburg, were occupied by flowing water and later abandoned to the wind. Landslides were induced in blocks of unstable ground wetted by the high levels of the impounded water. Lacustrine and alluvial deposits were laid down to become important soil-forming materials in the side valleys or to be redeposited as loess on the adjacent hills, and gravelly deposits were left where they now form sources of construction material.
In the Deschutes River canyon, the silty soils resulting from the Quaternary lakebeds form a particular type called Sagemoor (Mayers, 1964). This name is generally assigned to soils formed from silty deposits in this proglacial lake in the Columbia, Umatilla, Yakima, and Walla Walla river basins farther upstream.

Loess soil becomes progressively more common and thick eastward from the general longitude of The Dalles. East of the Deschutes River, it is the general soil of the uplands. The loess consists of clayey silt which was deposited in two or more episodes. It may have a maximum thickness as great as 20 feet in places north of Gordon ridge. In this work, the loess was not mapped because it had little direct bearing on the ground-water occurrences. Because of this loess cover, it is difficult to discern the underlying bedrocks in some places in the southeastern part of the area.

Along with the foregoing, the alluvial and colluvial (fig. 10) materials complete the roster of the geologic materials that underlie the area. The rest of the report concerns the main bedrock unit, the basalt of the Columbia River Group. 


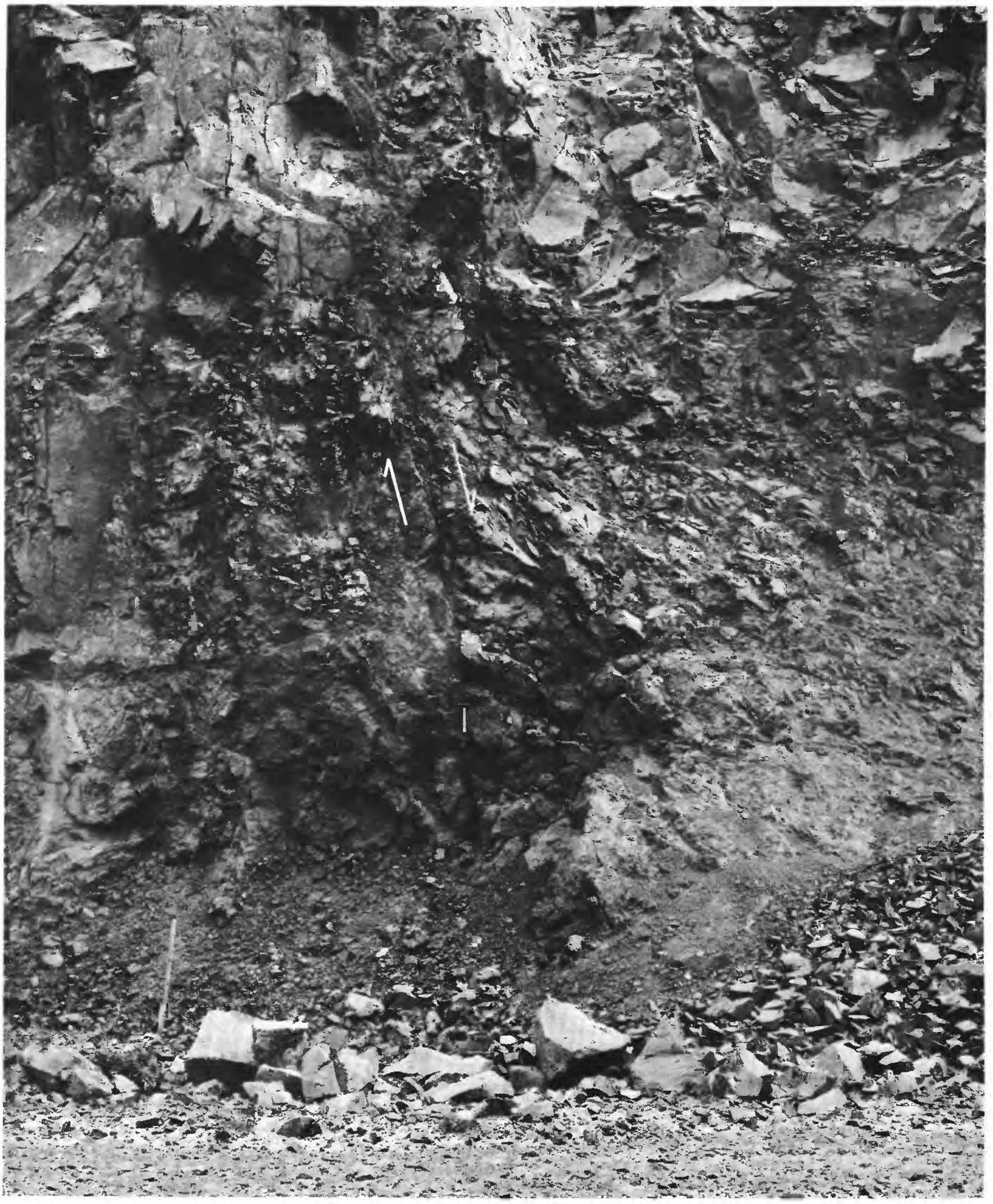

Figure 6.-Fault exposed by roadcut along left bank of Columbia River 0.85 mile west of Celilo Bridge. This small displacement and fracture zone is the east end of the east-dipping basalt shown in photograph (fig. 5) just above. Movement and breakage here is insufficient to stop lateral movement of ground water. Hand pick on fault below center of photograph is 14 inches long. Vertical displacement is down about 4 feet on right (west) side, per arrows. 


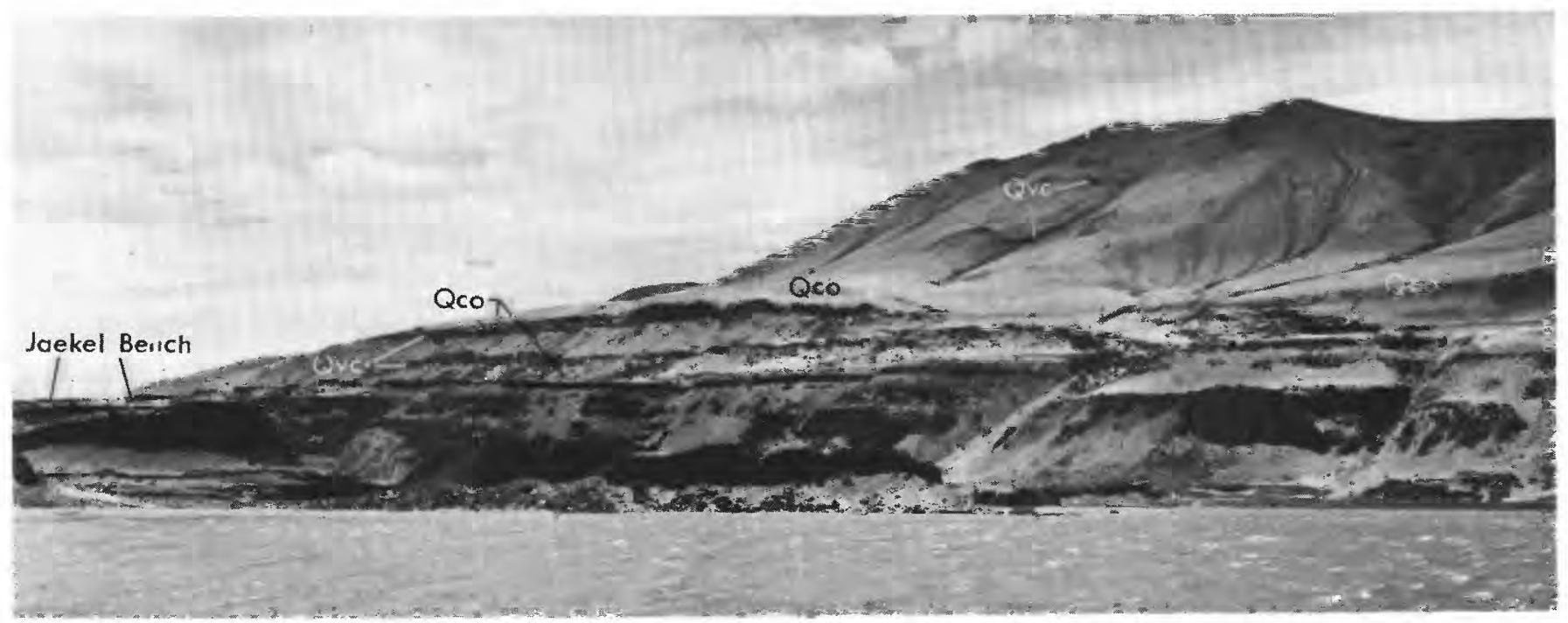

Figure 7.-View northwest across the Columbia River to Haystack Butte and Jaekel Bench. The east end of Miller Island is in the foreground. Quaternary lava $\left(Q_{\mathrm{vc}}\right.$ ) overlies part of the colluvium $(Q \mathrm{co})$. Part of a shoreline notch of proglacial Lake Lewis is visible in the colluvium at the extreme right center near 1,100 feet altitude.

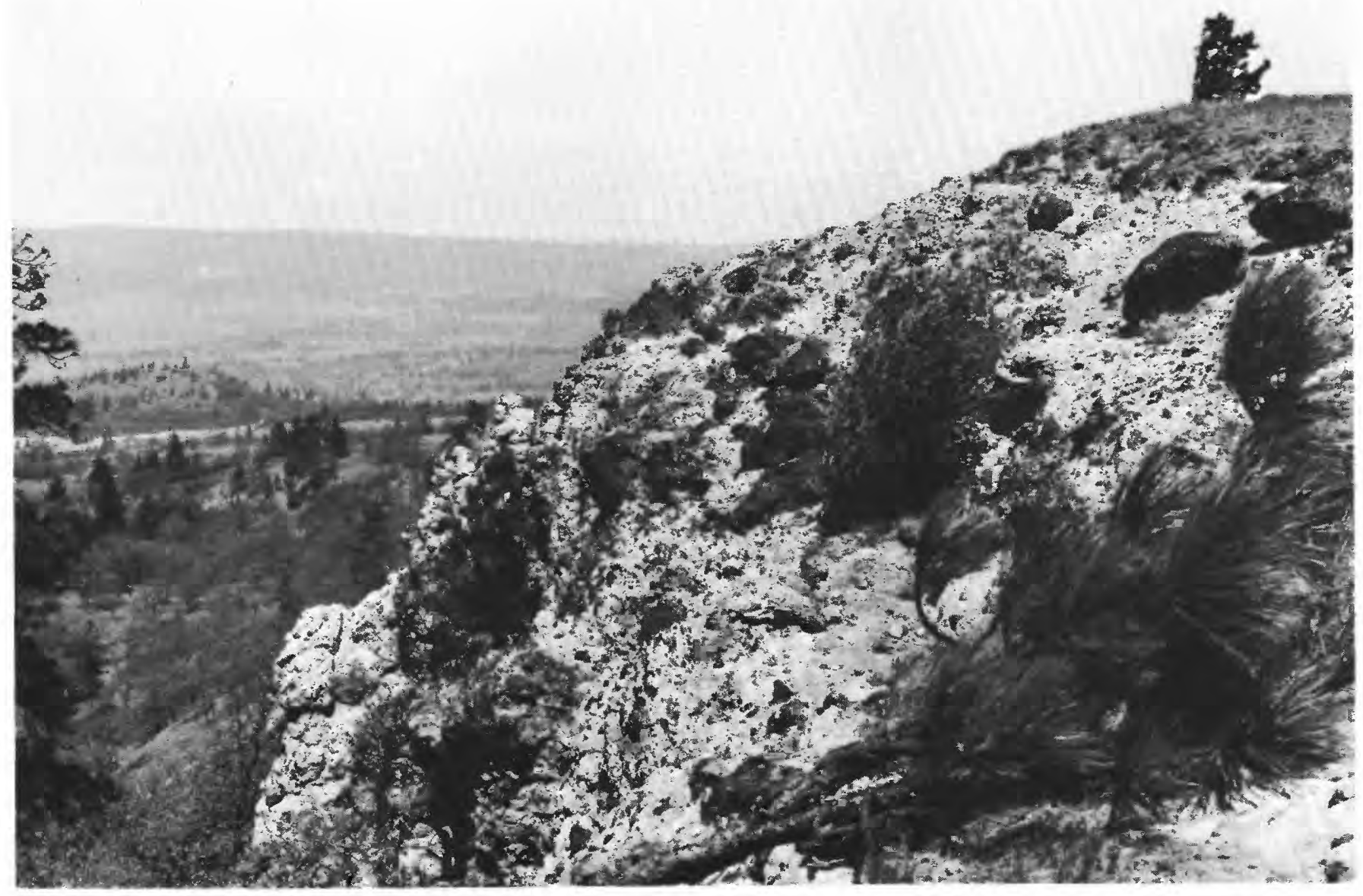

Figure 8.-Agglomerate of the Dalles Formation in erosional escarpment 3 miles southeast of Mosier (SE1/4 sec. 8, T. 2 N., R. 12 E.). Rounded andesite boulders, both scattered and in rude layers, comprise $10-60$ percent of the agglomerate. They form typical residual litter on erosinoal surfaces of this debris-flow type of deposit. 


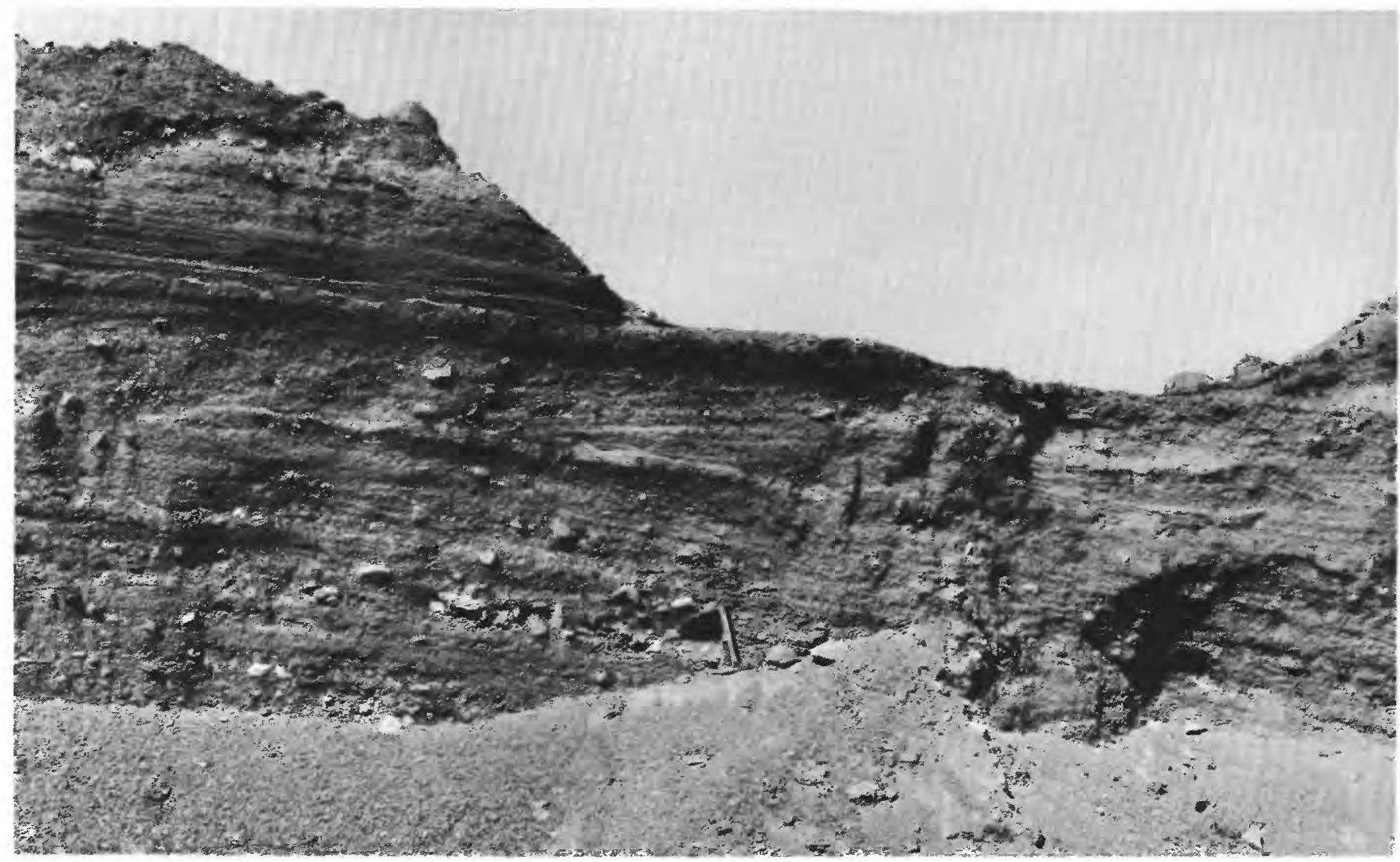

FTGURE 9.-Glaciofluvial gravels remaining on slope west of Fifteenmile Creek 4 miles northeast of The Dalles (SE1/4 sec. 28 , T. 2 N., R. 14 E.).

\section{GEOHYDROLOGY OF THE BASALT OF THE COLUMBIA RIVER GROUP}

\section{PHYSICAL AND HYDROLOGIC CHARACTERISTICS OF THE ROCK}

\section{PETROIOGIC FEATURES}

TEXTURE

The basalt is a black to dark-gray dense fine-grained and even-textured rock composed mostly of microscopic crystals with some intercrystalline glassy groundmass. An average basalt of this sequence has a nonporphyritic microgranular texture and is composed of labradorite $\left(A n_{50-55}\right), 55$ percent; augite (identified commonly as pigeonite by Campbell, 1950), 15 percent; magnetite, 5 percent; and brown glass and tiny microlites, 25 percent. As much as 10 percent olivine may be present in places in some flows. Some of the flows contain scattered lightgray labradorite phenocrysts that are as much as onefourth of an inch long. Crystals or globules of crystals of olivine or augite as much as one-eighth of an inch in diameter are visible in some of the basalt. Most of the rock has an even microgranular texture, but in a few places the crystals are so minute that the basalt has a flinty or near-glassy texture.

The mineral grains of the average basalt and the interstitial brown glass are dispersed evenly without directional orientation. The lack of directed alinements of crystals and the absence of abrasion of delicate crystals within the basalt, which have been observed by most petrographers, is interpreted to indicate that most of the crystallization, at least the main part of the plagioclase, occurred after the highly fluid lava had come to rest. Such a postflow age for the crystallization is suggested also by the general lack of crystals in the glassy phases of the basalt, the chilled margins, and the lapilli of intercalated lapilli tuff.

\section{LAYERING}

The most distinctive petrologic structures are layering and jointing. The layering resulted from the accumulation of the basalt as successive flows of highly fluid lava of the same general chemical and mineralogical type. The thickness of the major layers (the flows) ranges generally from 5 to about 200 feet and averages about 80 feet. Flows are nearly everywhere distinct 


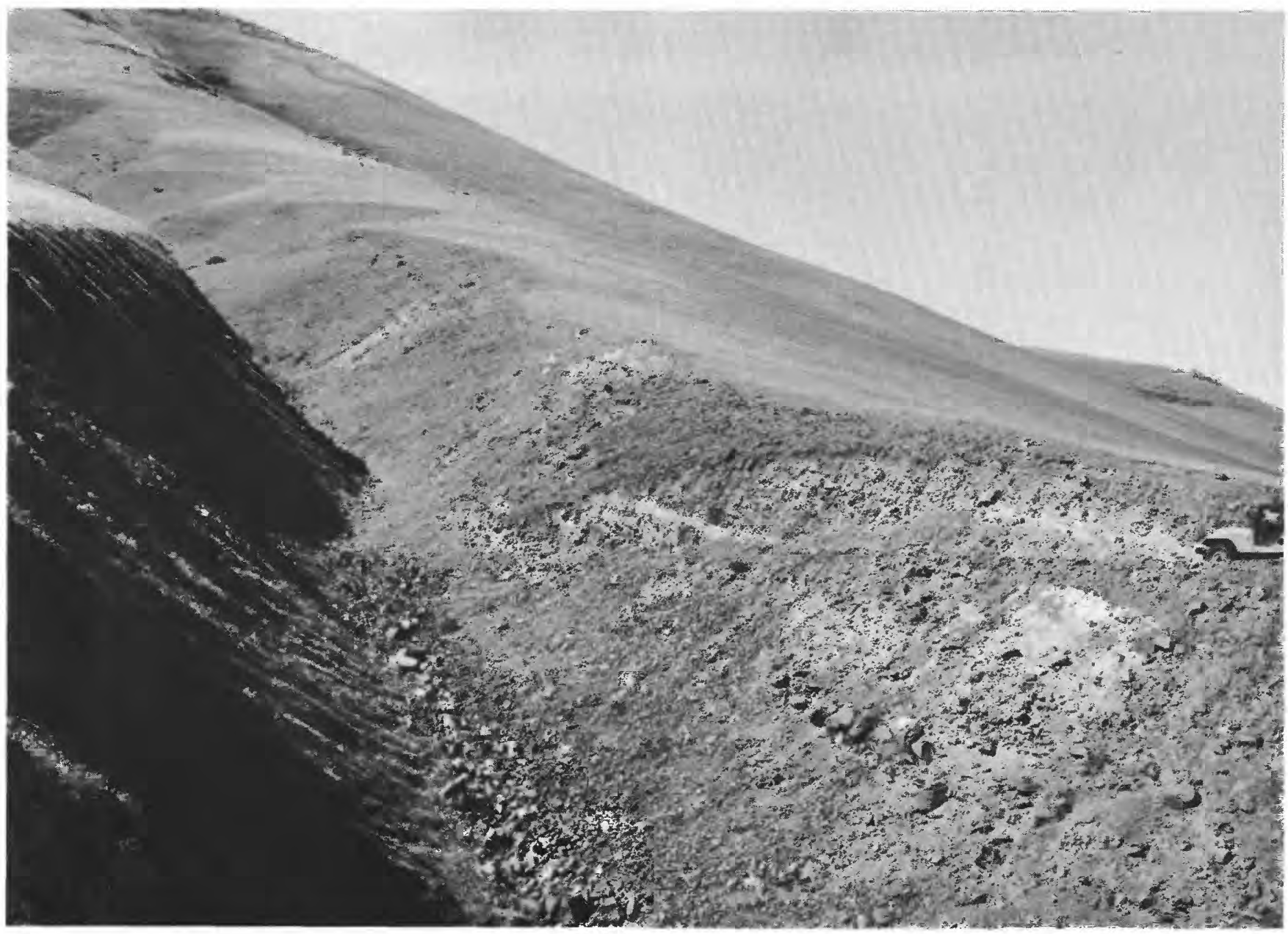

ErGURE 10.-Colluvium beneath mountain slope at southwest side of Haystack Butte. Deposit consists largely of rude bands of subangular basalt debris interbedded in thick zones of loessial silt containing scattered rock debris. Nearby, the colluvium is overlain by Pleistocene lava. The long colluvial slopes north of Maryhill Museum have been faceted by glaciofluvial waters to an altitude of more than a thousand feet (See fig. 7.)

stratigraphic elements, generally separated from the flow above and below by a difference in jointing, texture, color, susceptibility to alteration, interbedded sedimentary materials, a common vesiculated top and a "flinty" basal section, or other horizontal characteristics that break the vertical continuity.

Regardless of its thickness at any one place, a lava flow may be the result of a single lava effluence or a laminated composite formed by several related, separately arriving effluences. Each part of the composite lava flow is defined as a flow unit. (The flow units in this area are much more extensive than the 300 -foot-wide and 1/2-mile-long flow units which Nichols (1936) found common in lava in New Mexico and for which he derived this term.) A flow unit is a discrete part of a flow at a given place and was one single body of liquid lava that moved into the solidifying position. Flow units commonly have visible, but not always distinct, tops and bottoms; the contact zones between successive flow units show little or no oxidation, sediment, vesiculation, or evidence of stratigraphic interruption. The contacts between flow units in places are transgressed by jointing systems and in other ways were obliterated during the consolidation or late-liquid episodes of the adjacent lavas.

The distinctness of the top and bottom of some flow units differs from place to place; thus, a flow unit may in places be taken for a separate flow, yet be so indistinct as to go unrecognized nearby where petrologic or weathering conditions are different. In places, the lava of flow units mixed with the still-liquid parts of previous flow units or flows, an action which destroyed the con- 
tacts between them. Thus, the counting of flows and flow units and their thicknesses is partly arbitrary and has differed with the place, the time, and the observer.

Where the liquid lava flowed into water or over watercontaining materials, its globulation into pillows, pods, short lenses, and pipes is accompanied by a powdery or granular shatter product of partly hydrated and oxidized glass that may form an interpillow matrix of palagonite and tuff. This pillow lava is common in the top thousand feet of the basalt, and is especially prevalent in the top 500 feet east of Rowena. One pillow lava, about 100-150 feet below the top of the basalt, serves as a stratigraphic horizon marker from The Dalles eastward beyond the Deschutes River. Within that extent, the pillow-lava unit is exposed for several miles in the cuts of U.S. Highway 30 (old), near 200 feet altitude, eastward from the downtown part of The Dalles. Much of this extensive pillow layer (called the "highway pillow layer") has foreset bedding with $30^{\circ}$ dips to the south and west.

Lapilli and other granular basaltic ejecta, accompanied by yellowish sandy ash, occur as part of a thick flow, the third from the top, and underlies the surface (dip slope) east of Locke Lake, in sec. 35, T. 3 N., R. $12 \mathrm{E}$. Such fragmental materials contribute porosity to small parts of the basalt and show that effusive "fountaining" accompanied the extrusion of some of the lava. within this area.

For the most part, the basalt consists of successive flow layers so accordant that differences of $1^{\circ}-2^{\circ}$ in the general strike and dip are difficult to find. However, within the basalt, slight changes in dip are more common than is generally realized. Differences of $1^{\circ}-3^{\circ}$, due to local thickening or interflow subsidence, erosion, or other discordance-producing agencies, mark certain parts of the stratigraphic sections. These discordant parts are visible mainly where thick sections are exposed for great distances. One discordancy of about $3^{\circ}$ is present in the south wall of the Columbia Gorge just south of the town of Rowena. Others have been noted by previous workers elsewhere in the basalt region.

The stratigraphic top of the basalt lies on different laval flows in various parts of the area. Thus, the last of the basalt accumulation may be of slightly different age from place to place.

Some of the flows, especially those that are thick and resistant or petrologically distinctive, can be followed readily for many miles in canyon and mountainside outcrops, but even the very thick flows contain changes in petrologic details and in general appearance over distances of several tens of miles. Likewise, flows and flow units that are thin or discontinuous are interlayered throughout the vertical section of the basalt; thus, the flow arrangement in any one area is only partly related to the arrangement in a neighboring area and largely or completely discontinuous with the flows occurring in some distant part of the basalt region. Among the distinctive parts of the basalt section in this area are: (1) the thick flow-breccia layer that occurs about 400 feet below the top of the basalt in the lower part of the Deschutes River canyon and in the Columbia Hills north of the Maryhill area, (2) the 150-foot-thick "wavy-column" flow that forms most of Miller Island and shows conspicuously in the gorge walls at the general altitude of 200-400 feet eastward from Celilo, (3) the top 500 feet eastward from Rowena Gap, a zone in which there are several widespread and many local pillow lavas, and (4) the massive 200-foot lava flow ("Mosier Palisades flow") which forms the top of the basalt westward from Rowena Gap (fig. 12).

The rubbly tops of some flows, the brecciated flows, and the highly jointed parts of some flows are the principal parts of the basalt that transmit water (Newcomb, 1959, p. 4-8).

The permeable parts of the laval layers occur irregularly, and individual aquifers may be either extensive or discontinuous. The percentage of the rock unit that is formed by the permeable strata at any one place can be expressed as an average which is derived from the number of aquifers and their thickness per given thickness of the basalt.

Observations and drilling data accumulated throughout the basalt region indicate that about three aquifers, 10 feet, 5 feet, and 1 foot thick, occur on the average in each 300 feet of the top 1,500 feet of saturated basalt. At an estimated effective porosity of 25 percent as an average for the aquifers, this thickness of aquifer would indicate that only about 1-2 percent of the volume of the whole rock mass contains sufficient drainable pore space to yield water to wells. Such statistical characteristics have been summarized as an average water yield to large-producing wells in the basalt. The average yield to 10- or 12-inch-diameter wells, percussion drilled to at least 300 feet below the water level and pumped at drawdowns of $50-100$ feet is $1 \mathrm{gpm}$ (gallon per minute) of water for each foot of well penetration below the regional water table (Newcomb, 1959, p. 14).

No single spring that yields more than $100 \mathrm{gpm}$ was observed flowing into the rivers from the main groundwater body, but there are many of small or moderate yield. The general smallness of the spring flows from the basalt, despite the potentially large capacities of some of the aquifers, clearly shows that spring discharge is limited principally by the amount of recharge 
to the ground-water body. The recharge limitation on the flow of springs is especially evident at the upland springs flowing from perched water.

Because a permeable zone is interrupted laterally in many places and eventually terminates, single aquifers generally are identifiable for only a few miles. The main aquifer exploited near The Dalles is known as "The Dalles Ground Water Reservoir" (Stanley, 1959) and has been identified over a more extensive area than most any other single water-bearing zone in the basalt region. This aquifer extends beyond the Dalles area for which it was named (fig. 16).

Inasmuch as the permeable interflow zones are known to terminate and to thin in places along the strike, it is to be expected also that some end downdip between impermeable layers. In such stratigraphic traps, ground water will remain perched or under artesian pressure, or both. At present, the location of such stratigraphic traps cannot be predicted, and their presence may be estimated best on a statistical basis.

The changes in thickness observed at the outcropping ends of aquifers indicate that the lateral percolation of water will be obstructed stratigraphically at some places, and that perched ground water must occur where an aquifer pinches out and the water cannot move downward through underlying rocks. Thus, in upland plateaus without structural reservoirs, perched water is stored mainly in aquifers of limited extent or low to moderate permeability.

The descriptions of the stratigraphic details of the basalt layers in this report are limited to those significant in the occurrence of ground water or necessary to the recognition of key points in the stratigraphic position of aquifers in the different parts of the area. Within the basalt the individual lava flows, or at least groups of lava flows, commonly are mapped in detail only in a relatively small area, such as one in which a major engineering feature is planned.

JOINTS PRODUCED BY COOLING OF THE LAVA

Systematic cracks, or incipient partings, traverse the basalt. The main sets of cracks originated from the shrinkage of the solidified rock during its cooling. The most prominent joints are arranged in vertical columns which have a general hexagonal plan. Less conspicuous, but important, are systems of (1) flat, or sheeting, joints and (2) unsystematic miscellaneous partings that separate some parts of flows, especially basalt of a more glassy or flimly texture, into angular and irregular blocks of all sizes and shapes.
In most flows, the sheeting joints are prominent in the top 5-10 feet and are numerous, but less conspicuous, in the bottom few feet. In the central parts of the flow they may be largely invisible or form only discontinuous partings that cut across the joint columns.

The columnar jointing systems are of several types; at least one type is present, in varying degrees of perfection, in almost every flow. The columns are generally perpendicular to the flow contacts and range from 6 inches to 6 feet in width. They commonly extend across a large part of a flow, upward from near the base to the rubbly top of the flow; they are more perfectly formed near the center of the flow or flow unit. Vertical systems of both wide columns and narrow columns transgress some flows, though one system is usually faint when both are present. At places within the top part of wide columns, narrow 3- and 4-inch-wide columns ("microcolumns") extend inward from the outer columnar surfaces, curve downward, and either become progressively less visible toward the massive center of each of the wide joint columns or become the top of a system of narrow vertical columns. The jointing system is generally uniform within a given flow, but great variations from this uniformity are present locally.

In accordance with the type and number of the joint patterns and the closeness of the spacing of the joints, the basalt may be broken into small blocks (like brickbats) or it may be separable into long blocks of wide columns. The joints generally are open for percolation of water near the surface, in the zone of weathering, or in deformed flows that have been stretched during tectonic movements; but in undeformed basalt flows the joints commonly are tightly closed at depth. Nevertheless, in some of the flows, even the tight joints afford an avenue for slow movement of fluids and gases, as can be seen in the deepest parts of tunnels, where some tight columnar joints permit water to move down as a slow transfer that feeds a drop-by-drop procession from protruding points. In flows lacking permeable shrinkage joints, the only fractures allowing water passage across the massive part of the basalt flow may be the regional joints, described next.

\section{REGIONAL JOINTS}

In addition to the common shrinkage joints, the basalt has major joints, some of which have been called regional joints (Trimble, 1950). These long straight sets of parallel vertical cracks trend in various patterns across most of the basalt. They belong to the type of rock rupture called extension fractures. They seem to 
be as prevalent in nearly horizonal as in tilted basalt, but they are more conspicuous and are best known in the areas where the basalt is near the horizonal.

Because they occur in many areas of underformed, or very slightly warped, basalt, they are believed to include some major cooling structures. However, some of the regional joints are parallel to some lines of tectonic deformation in the basalt. The displacement along the parallel tectonic deformations may be either a result or a cause of the regional joint fractures. Consequently, at this time, the regional joints might be considered a hybrid between nontectonic and tectonic structures.

On plateaus, regional joints parallel to, and near, escarpments form a plane of weakness from which the basalt may rotate toward the declivity. This movement is taking place along many escarpments like those on the old highway west of Mosier where, near the center of sec. 2 , T. 2 N., R. 11 E., cracks as much as 1 foot wide have opened at the surface along the regional joints parallel to the nearby cliffs.

In places, the regional joints cut through several flows, and in other places they are restricted to one flow, below which they disappear in rubble zones at the top of the underlying flow. On the surface, the common regional joint extends straight across one flow for half a mile to 3 miles. It consists of (1) about a 10 -foot-wide zone in which parallel vertical fractures, without displacement, are twice as closely spaced as are the vertical columnar jointing planes in the other parts of the flow, and (2) a central 1- to 2-foot-wide zone in which the same type of planoparallel fractures are still more closely spaced, separated by about one-sixth the distance across the nearby columns.

In general, the horizontal movement of ground water along the permeable zones seems to take place readily across the regional joints, probably because little or no movement has taken place along the joints, so the rubbly rock of the aquifers continues across them.

The regional joints may be conspicuously etched by stream erosion. Some of those that prominently cut the rock benches near Spearfish, northeast of The Dalles, and near Celilo are shown in part by the topographic contours on plate 1 . The more fractured rock associated with these joints has been selectively eroded in spectacular fashion by river currents. Part of this selective entrenchment is typical of the familiar "scabland-channel" type of erosion that characterizes the basalt in river channels of "The Dalles type" (Bretz, 1924).

AUTOBRECCIATION

Flow breccia, or autobrecciated lava, is produced where consolidated parts of a cooling lava have been moved by impulse of still-liquid lava beneath. Flow breccia is uncommon in the basalt, but the tops of some flows and the entire thickness of some thin flows consist of fragmental lava that may have been broken by lava flowage after some solidification had taken place. The extensive aquifer a hundred feet below sea level at The Dalles, previously identified as "The Dalles Ground Water Reservoir" (Stanley, 1959), is apparently this type of breccia (figs. 16 and 17). It is described further on page $\mathrm{C} 27$.

Aggregations of angular blocks of basalt 1-18 inches in diameter, arranged in apparent disorder, make up parts of some of the lava flows. In the canyon of the Deschutes River, the tributary Gordon Canyon, and the mountain slopes north of the Maryhill area, such a breccia, about a hundred feet thick, forms an inconspicuous but widespread layer whose outcrop is 400 feet below the top of the basalt. It appears to be autobrecciated basalt and should form an important aquifer in places where it could store water. At one place in Gordon Canyon (SE1/4 sec. 12, T. 1 N., R. 15 E.), the small summertime flow of Gordon Creek disappears into the top of this brecciated flow, and an equal quantity (15-20 gpm) of water discharges from springs at the base of the brecciated flow a quarter of a mile farther down the canyon. The volcanic mechanisms that formed such rare flow breccias in these basalts created permeable zones of possibly great utility.

INTERFLOW SEDIMENTS

At irregular intervals, generally a few hundred feet apart stratigraphically, the contact zone between flows contains a sedimentary deposit. Observed in these interflows deposits were tuff, tuffaceous sand, silt, clay, diatomite, carbonized wood, coal, sandstone, conglomerate, and mixtures of these materials. The deposits are more numerous than commonly supposed, because they crop out only at the steepest places. Within this area, there are more of these interflow sedimentary deposits in the top thousand feet of the exposed basalt than in the lower thousand feet.

The interflow deposits range from 1 to 60 feet in thickness but generally are less than 10 feet. They taper to thin edges and become thicker and thinner irregularly along the strike. Some pinch out rapidly, whereas others, along a widespread stratigraphic horizon, consist of a great number of separate thin lenses that had accumulated in the sags of the rough top of the underlying lava flow.

The thickest such deposit observed is the 60 feet of tuff and sandy tuff that crops out below the uppermost 130 feet of basalt around Signal Hill, just east of The Dalles. This tuff underlies the extensive layer of pillow lava, called the "highway pillow lava," mentioned above. 
All the samples examined contained fragments of labradorite feldspar like that in the basalt; consequently, this tuff is considered a part of the basalt rather than an interfingering part of the Dalles Formation. This "Signal Hill tuff" interflow layer may continue north and occur sporadically in the Columbia Hills, where several landslides (pl. 1) of the basalt strata have occurred at unusually low angles of dip and a tuff was the incompetent layer in which the slide plane developed.

A 2- to 10-foot-thick silt zone containing wood and woody coal occurs intermittently along an interflow horizon about 250 feet below the top of the basalt between Mosier and The Dalles. A good exposure can be seen where woody coal is burning in the cut of the old highway around Crates Point at the north side of The Dalles Country Club (SW1/4NE1/4 sec. 17, T. 2 N., R. $13 \mathrm{E}$.). A similar sedimentary deposit is exposed in the highway bank 5 miles to the northwest $\left(\mathrm{NE}^{1} / 4 \mathrm{NW}^{1} 1 / 4\right.$ sec. 4, T. 2 N., R. 12 E.), and one has been reported in several wells, particularly at a depth of 110-120 feet near Murdock, Wash., a mile east of the first exposure just described.

A possible stratigraphic equivalent of the above coalbearing silt bed is exposed 7 miles west-northwest of The Dalles Country Club-on the mountainside northeast of Bingan, in NE1/4 NW1/4 sec. 20, T. 3 N., R. 11 E. It consists of a bed of micaceous sand and white volcanic ash, which crops out about $300-400$ feet below the top of the basalt. The width of the sandy soil underlying the mountain slopes at this place indicates that the bed must be several tens of feet thick in places, though only 7-8 feet of it could be observed in place along the banks of old logging roads. Under soil cover, it may continue southeast around the brow of the escarpment of the Columbia River Gorge, and may be the weak strata from which the top 400 feet of the basalt slid off the now-bare dipslope northwest of Locke Lake.

Most of the layers of pillow lava overlie a stratum of waterlaid sedimentary material, generally silty ash, diatomite, or sandy tuff. This sedimentary material extends up into some of the pillowed lavas as a result of either in situ interdeposition or physical intermixing caused by steam-accompanied injection of the sedimentary material into the stratum of lava.

\section{WEATHERING}

The basalt has a thin oxidation skin on most all joint surfaces and on all but newly broken faces. Artificial fractures have subconchoidal surfaces along relatively even planes that bound highly irregular shaped blocks. Within each flow, the basalt is largely fresh, undecomposed rock and lacks extensive secondary alteration of the minerals except in some places where weathering has penetrated differentially and in a few zones where hydrothermal change has occurred. There is weak, spotty zeolitic filling of cavities and some reorganization of minerals in zones of fault brecciation.

Where the basalt has formed the land surface for a large part of its geologic history, it is decomposed to depths of as much as 50-60 feet and has been altered greatly by ovidation and selective leaching. Such deep weathering is present on Burdoin Mountain northeast of Bingen. Elsewhere, the basalt top is unweathered or only mildly weathered.

\section{FOLDS AND FAUITS}

\section{MAJOR FOLDS}

Two broad upwarps branch northeastward at the east side of the Cascade Range - the Bingen anticline and the complex structure, or anticlinorium, formed by the Mill Creek Ridge and Columbia Hills anticlines. To the southeast of these anticlines are respectively, the Mosier syncline and Dalles syncline. The average vertical displacement between these two main upwarps and their associated synclines, is nearly two thousand feet. The widths of the two main anticlines and two main synclines (from 4-8 miles) are generally similar except for the Dalles syncline, whose south flank is a regional dip slope many tens of miles long. Geologic sections across these major structural features are shown on plate 1. The folds are symmetrical, in general, but contain some parts which are asymmetrical, dual, branching, faulted, or otherwise complex.

The Bingen anticline broadens north of the Columbia River, where its limbs become inconspicuous in the high plateaus north of Burdoin Mountain. It is almost terminated on the south by the east-west cross fault along Whiskey Creek. South of the fault which is followed by Whiskey Creek, the Bingen anticline is shorn of its west limb by the downdrop along the adjacent large northsouth fault.

The Columbia Hills anticline and its topographical equivalent, the Mill Creek Ridge anticline, are paralleled by the Dalles syncline on the south and by the Mosier syncline on the north. The compound uplift would be properly designated as an anticlinorium, but the shorter name Columbia Hills anticline, is used here to designate the compound uplift which extends from its southern end near Wasco Lookout (secs. 32 and 33, T. 2 N., R. 12 E.) northeastward and then eastward beyond this area. Its southern part, herein called the "Ortley segment," was named the Ortley anticline by Williams (1916, p. 122), who also named the Bingen anticline and the Mosier syncline. 


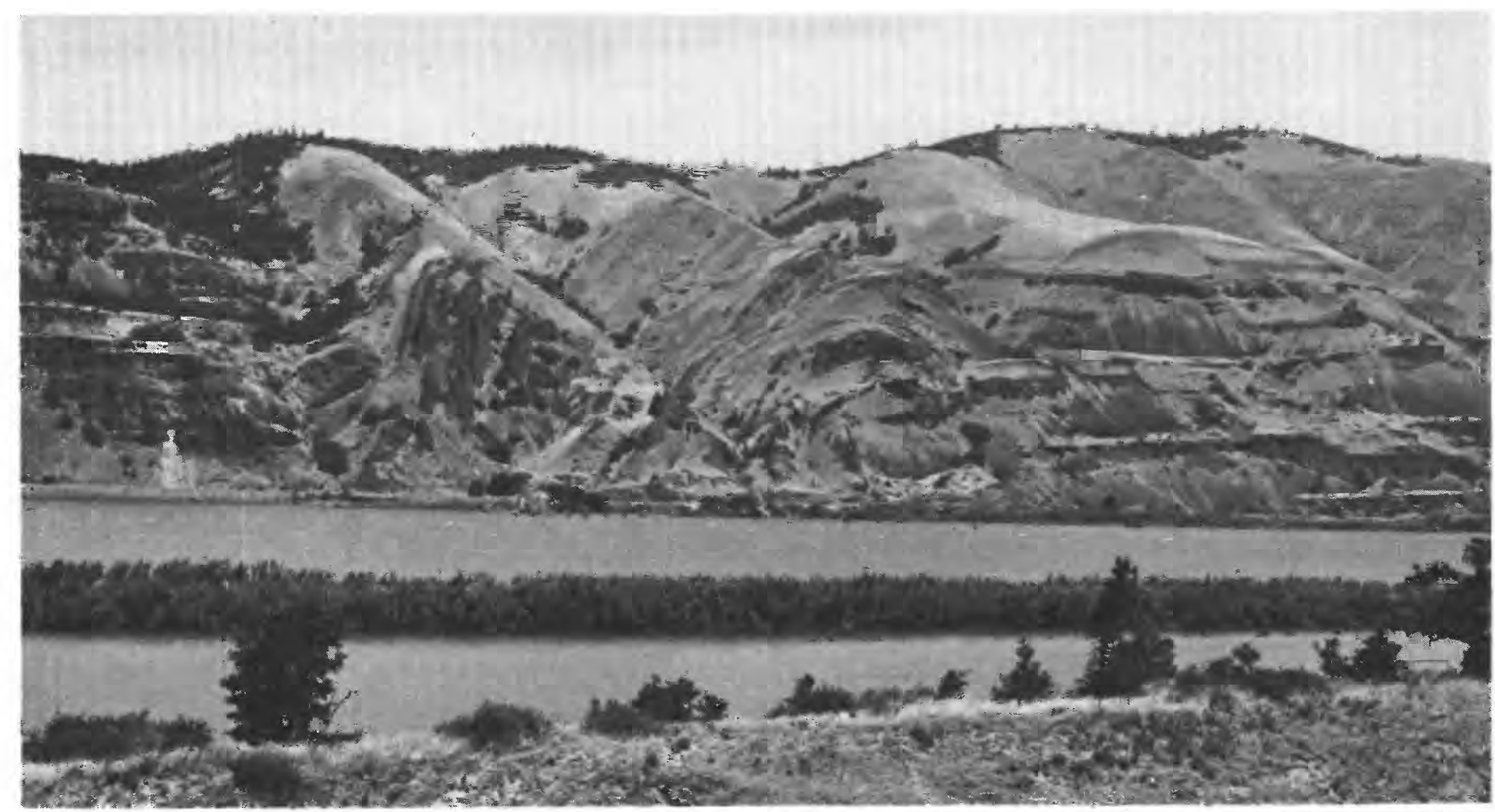

Figur 11. - View north across the Columbia River from Rowena. Part of the basalt in the asymmetrical fold of the Columbia Hills anticline reaches the vertical near river level. Flexural slippage is evident in the oversteepened limb.

To the northeast and east from Rowena Gap, the Columbia Hills anticline is divided into segments by sharp folds or faults which trend northwest obliquely across the main structure and continue to the northwest out of the area (pl. 1). Two of the segments have markedly asymmetrical cross sections. In the steeper sides of the asymmetrical sections of the anticlines and on the sharp turns, like that at Stacker Mountain (sec. 30 , T. 3 N., R. 14 E.), the basalt strata in places have been overturned, faulted, and thrust faulted. The mapping in greater detail of the structures at these places was precluded by the extensive brecciation, shear displacements, slump disturbances, and the colluvial cover, all of which are characteristic of these places of severe rock deformation.

In the south side of Rowena Gap, the two limbs of the Ortley segment of the Columbia Hills anticline are somewhat symmetrical. The northwest limb is much steeper in the first exposures north of the river. (See fig. 11.)

The western large downwarp, the Mosier syncline, begins as a gentle northward-plunging sag at the eastern side of Hood River Mountain. Six miles north of its beginning, its axial area forms the picturesque inwarddipping trough that is followed by the Columbia River south-southwest to Mosier (fig. 12). North of the Columbia River it becomes progressively broader and shallower, and is a barely distinguishable sag where it crosses High Prairie. It continues northeastward beyond the area, at least to where the basalt of the Columbia River Group is covered by young lavas near Goldendale, Wash., 9 miles northeast of the northeast corner of this area. Northeastward from near Stacker Mountain, another broad and relatively shallow syncline, the Swale Creek syncline, and a secondary anticline lie between the Mosier syncline and the Columbia Hills anticline. The Swale Creek syncline continues many miles eastward beyond this area (Newcomb, 1967, fig. 1).

South of the Columbia Hills anticline, the axial area of the broad Dalles syncline follows an almost imperceptible sag in the broad floor of a downwarped trough that extends northeast down Mill Creek from beyond this area. The syncline widens northeastward to where 


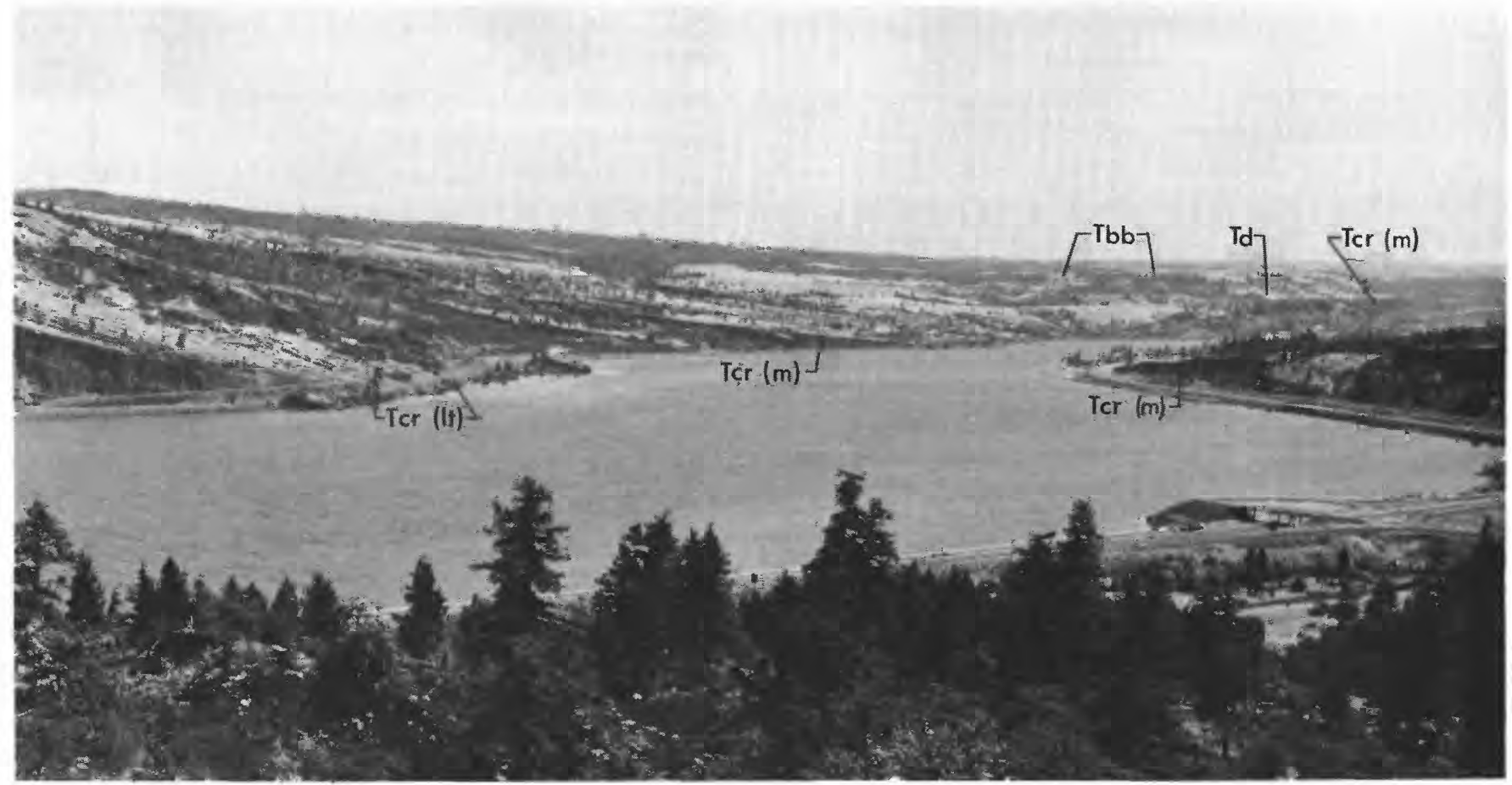

FIgURE 12,-View northeast along the trough of the Mosier syncline from an escarpment just west of Mosier. Highway exit to Mosier is in right foreground. Ter $(\mathrm{m})$, the Mosier Palisades flow, the top flow of the basalt of the Columbia River Group in the Mosier area; Td, Dalles Formation. Tbb, basalt porphyry of the Balch Lake area; Tcr (It), lapilli tuff, marks lava-fountain orifices in the basalt.

the flat-lying basalt is exposed at The Dalles and Dallesport. From this low structural sag, the basin at The Dalles, the syncline curves to the east. For part of its length within this area, the nearly flat-lying basalt of the axial zone of this syncline is followed westward by lower Fifteenmile Creek and, farther east, by China Hollow Creek.

Far beyond this area, the Dalles syncline (Piper, 1932, p. 134) alines with the broad syncline of the Umatilla Valley (Hogenson, 1964, pl. 1) ; together they form the great structural downwarp which the Columbia River follows westward for 100 miles from Wallula Gap to Rowena Gap (Newcomb, 1967).

\section{MINOR FOLDS}

Several of the secondary folds or groups of folds shown on plate 1 are known to have some effect on the ground-water conditions and must be mentioned briefly here.

The most important of the subordinate features within the Mosier syncline are (1) the narrow anticline which underlies Rocky Prairie, and (2) the associated Orchard syncline. Flexural slip and flowage within the basalt layers that were bent in the narrow anticline have destroyed much of the permeability of the basalt near the axial plane of the anticline. The resulting impermeable breccia has caused the impoundment of ground water, as described in the section on "Local examples of structural control of ground water," page C23. (See figs. 2 and 15.) The flexural flowage (Donath and Parker, 1964), a type of brittle failure, is a common type of fault breakage widely distributed in the overstressed parts of the narrow and tight folds of the basalt.

Near the junction of Lugan and Government Flats, a shallow arch continues the narrow Mill Creek Ridge anticline through the uplands, where only the Dalles Formation is exposed. The anticline continues north of Chenoweth Creek as the small fold along the divide of Chenoweth and Badger Creeks and, with interruptions, has a continuation in the alined Wetle Butte anticline.

The Wetle Butte anticline forms the general ridge that divides the drainage of Badger and Chenoweth Creeks, crosses the lower part of Badger Creek, swings to the east across the scabland channel north of Foley Lakes (NE. cor. sec. 30, T. 2 N., R. 13 F.), traverses the sharp arch in Wetle Butte, and diminishes to nearly horizontal basalt at the east bank of the Columbia River. 
Possible structural equivalents of the Badger Creek syncline and other secondary structures south of the river occur northeast of the Columbia River as the set of short anticlines and synclines north of Smithville. Like the minor warpings just described in Chenoweth Creek valley, these folds seem to have resulted from shallow stress that was not relieved by, or was created by, the displacements of the major folds.

From Stacker Mountain eastward, the Columbia Hills anticline has many associated minor folds and faults. The folds that trend northwestward (in secs. 19 and 24, T. 3 N., Rs. 13 and 14 E.) from Stacker Mountain, the parallel smaller anticlines that lie to the south of the main axis, the prominent northwest-trending Warwick fault, the transverse Davies Pass syncline, and the northwest-trending fault crossing the Columbia River just below the railroad bridge at Celilo are some of the subordinate structural displacements important to the occurrence of ground water.

Several broad folds in the long, gentle south limb of the Dalles syncline bring the basalt near, or to, the surface. These folds and some associated, largely unknown, faults cause ground water to remain at comparatively high altitudes. One of these folds is an anticline which trends roughly parallel to the axis of the Dalles syncline and transverse to the regional dip of the basalt. The fold, herein called the Lash Ranch anticline, arcs across the valleys of Threemile, Fivemile, and Eightmile Creeks in the south part of T. 1 N., Rs. 13 and 14 E. It shows on the geologic map (pl. 1) largely as an "island" of basalt on Threemile Creek and a wider than elsewhere exposure of basalt on Fivemile Creek (Piper, 1932, pl. 11). Each of the creeks crosses this anticlinal axis and continues to the northeast after flowing eastward parallel to, or across, the syncline at the southern side of the anticline.

A sharp anticlinal bulge, which has a vertical displacement of about 200 feet, trends along the canyon slope south of Gordon Ridge, in the southeast part of the area. Just south of this Gordon Ridge anticline, an accompanying 100 -foot-deep structural sag forms the syncline followed westward by the creek in Harris Canyon to the Deschutes River (see fig. 13). East of Gordon Butte, both folds curve to the east-northeast. Beyond this area, the syncline forms the prominent sag followed eastward by Gordon Hollow and by springfed Grass Valley Creek, and the anticline forms a 100foot-high linear bulge that continues for many miles along the north of Grass Valley Creek.

\section{FAULTS}

Besides the minor faults and the dispersed faulting that is obscured in steeply folded parts of the basalt, there is major faulting within the Bingen anticline and there are two faults that have special significance to the tectonic and hydrologic situations.

The east-west fault along Whiskey Creek and the large north-south fault are parts of the strong deformation along the east side of the downdropped block which underlies the Hood River valley. Also, faults alined along the sides of the Columbia Gorge suggest that the river followed faults when cutting Bingen Gap across the Bingen anticline. A zone of fault-shattered basalt several tens of feet wide trends N. $40^{\circ}$ W., where it crosses the old Columbia River highway in the SW. cor. sec. 33 , T. 3 N., R. 11 E. North across the river, a nearly parallel band of fault breccia is exposed in the north-central part of Bingen along the lowest part of the basalt escarpment.

One of the faults of special tectonic and hydrologic signiticance is herein called the Chenoweth fault. It bounds the basalt along part of the southeast side of the Ortley segment of the Columbia Hills anticline (Piper, 1932, pl. 11 and p. 136) and continues westward to form the south limit of basalt exposed in the West Fork anticline. The fault was exposed by a test pit at the NE. cor. sec. 36, T. 2 N., R. 12 E., where a 1-foot-wide zone of clayey gouge separates the basalt hanging wall from the massive agglomerate of the Dalles Formation in the footwall and lies in a plane dipping $68^{\circ} \mathrm{N}$. At the divide between Mosier and Chenoweth Creek valleys, the alinement of the fault trace also indicates a reverse displacement, a dip north toward the upthrown side. West of the north-south offset, along a cross fault half a mile west of that divide, the main fault may be nearly vertical or may dip steeply southward, as it does in normal fashion along the north side of Kellar Creek canyon.

The Warwick fault, whose scarp forms the west face of the high ridge topped by Haystack Butte, trends northwestward along the sharp west faces of small domes alined across the Swale Creek valley. Beyond the area mapped, the trace of the Warwick fault follows a linear sag for 20 miles before it disappears under alluvium and young volcanic rocks in Camas Valley at a point only 15 miles southeast of the peak of Mount Adams. The fault was mapped by the writer a decade ago, and is shown on the geological map of Washington published in 1961. Where this fault crosses the Klickitat River 5 miles north of this area, it apparently forms a conduit along which carbon dioxide rises to the canyon floor. The gas is recovered commercially from springs and wells. The fault is one of several parallel strikeslip faults trending northwestward, about $3-8$ miles apart, across the plateaus north of this three-quadrangle 


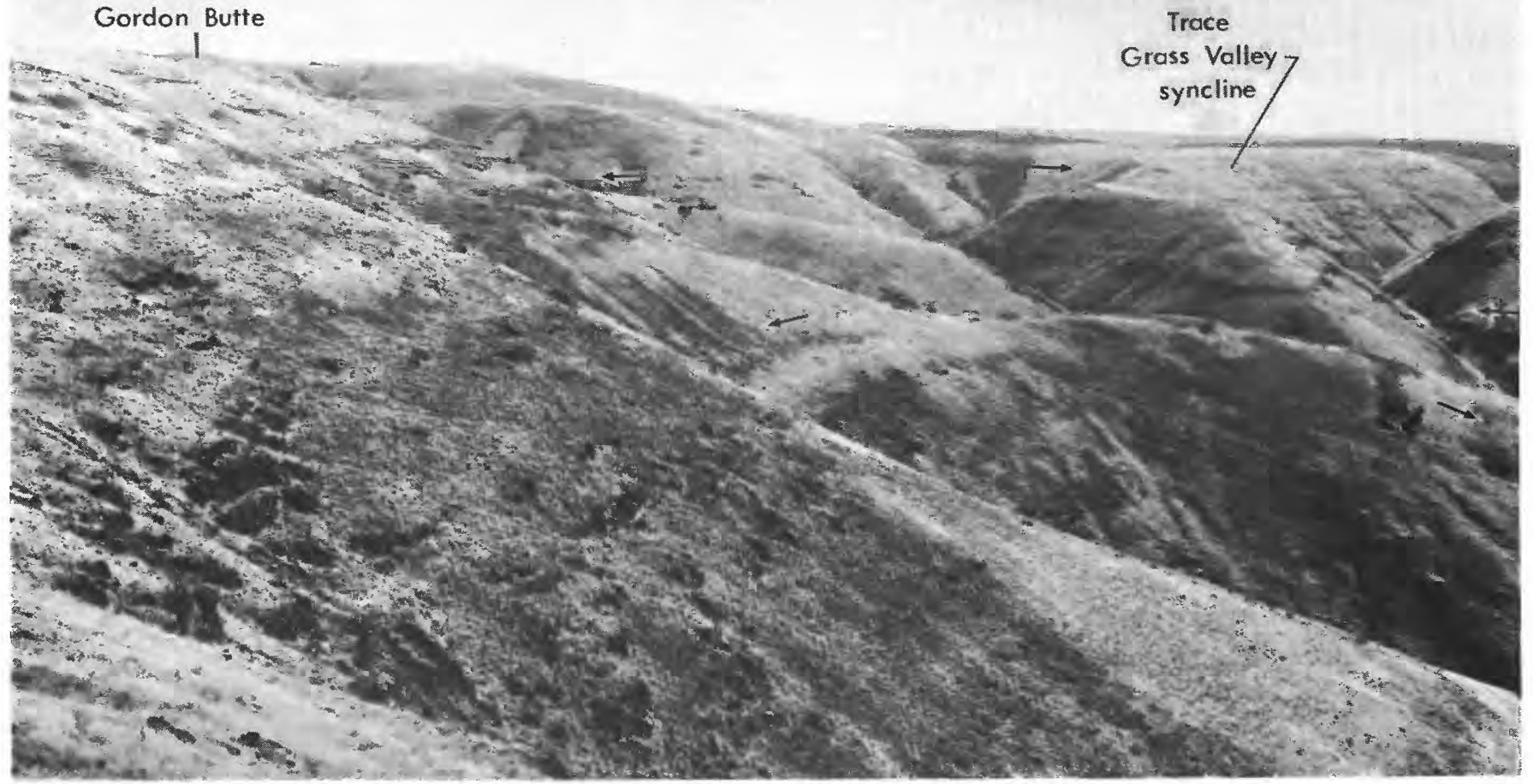

FigURE 13.-View east along the upper part of the south slope of Gordon Ridge. The low anticlinal bulge transverse to the regional slope causes ground water to be impounded and to flow out along the Grass Valley syncline at the right. Arrows indicate dip of basalt flow away from the anticlinal crest and (at the right) into the adjacent syncline.

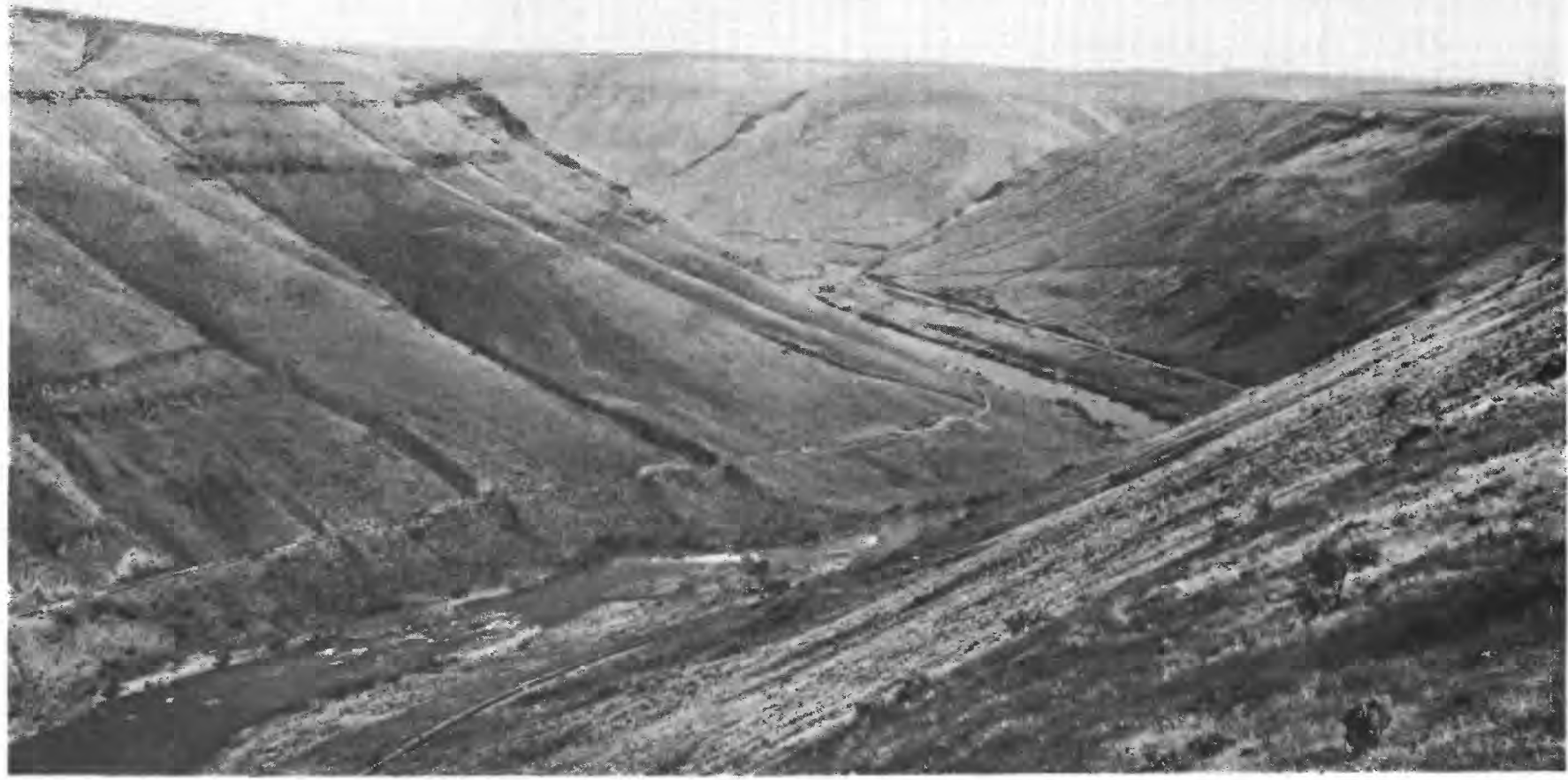

Figure 14. -View south from the west rim of the 1,000-foot V-shaped canyon of the Deschutes River. The unimproved grade of Free Bridge Road is evident along the west side in the right center ground. 
area. Much of their lateral slippage is taken up in the steeply folded parts of the Columbia Hills anticline. On the Warwick fault, strike-slip movement is southeast on the northeastern side. At its southeastern end, the fault curves toward an east-west alinement and divides into several slip planes whose displacements are $a b-$ sorbed in the steeply inclined basalt along the south limb of the Columbia Hills anticline.

Among many minor faults are some within the axial part of the Dalles syncline near the Dalles Dam, where a small fault (Piper, 1932, pl. 11) crosses the river just downstream from the Dalles Dam. The fault, called the Quarry fault in this report, is well exposed in a small quarry near the center NE $1 / 4$ sec. 1, T. 1 N., R. 13 E. (pl. 1). Its eastern side is upthrown about 40 feet in the exposure at the south side of the former U.S. Highway 30 . In the quarry, the fault is an irregular 18-inch-wide fracture and gouge zone, dipping $80^{\circ}$ to the northeast; on the eastern side of this fault, blocky basalt is raised opposite pillow lava on the western side. Some slippage seems to have occurred lengthwise, parallel to the strike of the fault. The pillow lava on the west side of the fault is the "highway pillow lava" exposed in the bank of the old highway westward to the downtown part of The Dalles.

\section{GROUND-WATER OCCURRENCES}

TECTONIC CONTROLS ON THE GROUND WATER

The tabular separation of aquifers within the general layered strata of the basalt, as described above, creates an arrangement by which folds and faults can exert a primary influence on the ground water. The effects of the deformation of the basalt on the ground water can be interpreted from some of the facts about water on the surface, from the water-bearing characteristics of the basalt, and from data on ground water. These structural effects on ground water in the basalt are largely (1) greater accessibility of the aquifers to recharge (water descending from the surface), (2) easier transfer of water downward and laterally along greater hydraulic gradients, and (3) larger and more numerous storage reservoirs of ground water behind structural barriers.

EASE OF WATER ENTRY INTO THE BASALT

Tectonic deformation, commonly followed by erosion, causes the basalt strata to be beveled by the land surface and makes the permeable zones accessible to infiltration. This ease of entry for water is especially evident in anticlinal mountains, which receive some of the greatest amounts of precipitation. Also, it is evident in ravines and stream valleys that cross tilted basalt.
Examples of the influence of structure on the infiltration and discharge of ground water occur (1) on the crest of the Columbia Hills anticline north of The Dalles, where rainfall and melting snow infiltrate into erosion-bared permeable strata, (2) at springs in the ravines farther south, where those permeable strata are again exposed, (3) in Gordon Creek where the summertime flow of the creek disappears into an exposed flow breccia, and (4) in the aquifers of the Orchard syncline, which are filled to the altitude at which they crop out in Mosier Creek farther south, as explained on page C23.

A summary of the examples seen would class the beveled aquifers crossed by gravel-bedded streams as the greatest potential sites for ground-water recharging, and the horizontal basalt flows of great plateau extent as the least likely sites for recharge. Intermediate between these extremes is the tilted basalt cut by canyons-a condition common in this area.

\section{DOWNDIP, A PREFERENTIAL DIRECTION OF GROUND-WATER MOVEMENT}

After it infiltrates the basalt, water moves downward along interblock spaces, joints, and other fractures until it reaches the base of a zone of permeable rock. In most of the basalt, this base of a permeable zone lies along an irregular stratigraphic horizon in the top part of the dense center of a lava flow. In horizontal basalt, the hydraulic gradient away from the point of infiltration is small because the amount of vertical head, which at the maximum could be no greater than the thickness of saturated rock, must furnish the drive to distant outlets of the aquifer. By contrast, it is apparent that a dip of the basalt as low as $3^{\circ}$ would provide a drop of 277 feet per mile in the aquifers, and the potential hydraulic gradient due to the tilt would greatly exceeed the gradient due to saturated thickness of any horizonal aquifer.

The rapid drainage away from points where water infiltrates into the upper end of dipping aquifers is illustrated by the waterless condition of level areas on anticlinal crests where permeable basalt is beveled and also by the loss of water from creeks where they flow onto aquifers inclined toward distant outlets. The location of springs predominantly on the updip side of stream courses which trend transversely to the inclination of basalt (pl. 1) illustrates the preference of the ground water for downdip movement. (Note the springs in China Hollow and Fifteenmile Creek valleys and in Rock Creek valley southwest of Mosier, pl. 1.)

OBSTRUCTION OF PERColation IN AQUifers

The downdip movement of water is interrupted, in places, by tectonic structures. A synclinal sag or fault, 
transverse to the downdip direction of ground-water movement, causes underground accumulation of water.

The commonest type of obstruction to ground water in tilted basalt results from a rise of the relatively impermeable base of an aquifer. Where it occurs in a long dip slope, such an obstruction starts at the edge of the transverse anticline that creates the synclinal sag in which ground water accumulates. Commonly, ground-water impoundment by such a structure-an anticlinal barrier-occurs both in perched ground water and in ground water below the main water table. The storage of water in such obstructed parts of the aquifers will increase to the level where spillage over the barrier, to land surface, or to other aquifers, or the leakage to underlying rock, equals the inflow from updip. Springs discharging to streams that trend transverse to the regional dip commonly occur at these synclinal sites; several examples are evident on the map (pl. 1) and are described beyond.

From these observations of the common impoundment of ground water in layered basalt upgradient from an anticline, a spill of ground water would be expected to occur where the base of each equifer crosses the axial plane of a mildly warped anticlinal barrier (figs. 17 and 18). This spill at the anticlinal axis within each separate aquifer would result in a vertical drop of the water table at the axial plane. It also would cause the successively deeper aquifers within the synclinal reservoir to have successively lower water levels (fig. 18). Such a postulated change in ground-water levels at the crest of an impounding anticline could not be evaluated fully in this area. Indication that this kind of a multiple-level spillway occurs at the axis of the mildly warped Lash Ranch anticline could be interpreted from the different water levels in the Martin (32G1), the Stark (28R1), the Elton (22R1), and the Renken (22B2) wells on Threemile Creek. The altitudes of water levels in these wells are, respectively, 1,340, 880, 180, and 90 feet. Several other wells have water levels that may be explained by similar geologic conditions. Full field demonstration of such successively lower levels of ground water, because of successively lower stratigraphic spillways in aquifers crossing the crest of a nonfaulted anticline, awaits more data, but the existence of the phenomenon is suggested by observations here.

Besides the upturn of the aquifers in anticlines, the most common obstruction to lateral percolation is the crushed rock, or the offset, along a fault plane. The faults in this area are the sites of rock movements that ranged from minor displacements along breaks associated with folded structures to great shear displace- ments along major fractures of the earth's crust. Most known faults in this area are near vertical.

Fault zones block the percolation of ground water by destruction and offset of the permeable zones of the basalt. The amount of movement necessary to create such a barrier varies with different aquifer thicknesses and ground-water pressure. Along normal faults, barriers result from movement of only a few tens of feet. One fault, along which the walls are displaced about 4 feet (see fig. 6), is not a significant barrier to the ground water, whereas another the "Quarry fault", with 40 feet of displacement, occurs between wells having water levels differing by 100 feet in altitude and seems to cut off the aquifer laterally. The completeness of the water shutoff differs at each barrier and along any one fault, where stoppage may be complete or partial at different places and in different aquifers.

Fault breccia and gouge are much less permeable in a horizontal direction than were the permeable parts of the unbroken lava flows. Water may seep slowly across some of these breccias and cause some leakage from fault-barrier reservoirs, but the fact that water is not transmited readily is demonstrated by the great difference in water levels on opposite sides of fault barriers (fig. 16). Water does seep at a slow pace vertically along some planes in the fault-zone breccias, where no vertical movement of water would occur if the rock mass consisted solely of well-layered, near-horizontal basalt.

\section{MAJOR OCCURRENCE, BENEATH THE MAIN WATER TABLE}

The graded rivers maintain a sloping base level to which ground water drains. This drainage level is near the top of the continuous zone of saturation in the earth's crust, which is known as the water table. To distinguish it from the numerous local perched water tables in this report, the water table is designated "the main water table." In most places, the main water table has adjusted upward to the new river levels maintained artifically in recent years.

In wells that tap aquifers at a level lower than a nearby river, the static water level generally is near the level of the river. Wells at Bingen, Lyle, Mosier, Rowena, The Dalles, Moody Station (26P1), Wishram (17L1), Biggs, Maryhill, and other places tap ground water standing near river level. The yield of wells tapping ground water below the main water table depends largely on the thickness of basalt and, hence, the number of aquifers drilled below the water table (Newcomb, 1959, p. 10).

Because the layers of the top 2,000 feet of the basalt are exposed to the rivers that bevel the two main anti- 
clines, a good opportunity exists for interflow between the ground water and the river. The ground-water levels in wells tapping highly permeable aquifers near the rivers show evidence of this intermovement of surface and ground water except in a few places, such as "The Dalles Ground Water Reservoir," a notable exception described on page C27.

Locally, the main water table is slightly higher or lower than the river nearby owing to some confinement of, or to some artificial draft upon, the ground water. The water percolates toward the rivers, and its height above the river-level control at any place is theoretically related directly to the amount of water available for transmission and to the resistance the rocks give to percolation toward the discharge points.

In roughly comparable areas, natural gradients of the main water table have been observed as low as about 6 feet per mile near Lind, Wash. (Walters and Grolier 1960, pl. 2), and as high as about 30 feet per mile in the Walla Walla River valley below College Place (Newcomb, 1965, pl. 1, table 1).

At some distance from the rivers, the nearly horizontal main water table may lie at great depth below the land surface. As the land surface ascends to the plateaus or up the steep ungraded valleys of the tributary creeks south of the Columbia River, it rises many hundreds of feet above the position of the main water table. Normally, the main water table would be a little above the 72-foot altitude at which the river, westward from The Dalles, is usually held by Bonneville Dam. On the plateaus, deep wells to tap ground water below the main water table have been drilled only south of The Dalles. The water levels in the Renken well (22B2) and the Blaser well (13N1) stand at an altitude of about 90 feet. Both wells are 3 miles from the Columbia River and have water levels comparable to that in "The Dalles Ground Water Reservoir" prior to the 50-foot decline of the water level due to pumping from that aquifer during the period 1955-65.

\section{MINOR OCCURRENCES}

Besides the principal body of ground water beneath the main water table, ground water occurs in distinct bodies perched in the basalt underlying the plateaus. The perched ground water may be loosely designated by the relative height of its position: (1) high perched and (2) intermediate perched. Locally, either or both of these may discharge to streams flowing in valleys at local base levels high above the main water table. However, another distinction between the two subdivisions is that the intermediate-perched water generally is accompanied by permanent streams, such as Fifteen- mile Creek, whereas the high-perched water may discharge to intermittent streams or evaporation areas. Ground water impounded as a result of structural or stratigraphic conditions occurs in these perched positions as well as beneath the main water table. Most of the ground water (at any level it may be stored in tilted basalt) is confined under pressure; consequently, at any of the three positions (main water table, intermediate perched, and high perched), ground water may have a high pressure level in relation to the land surface, and even may flow from wells.

\section{HIGH-PERCHED GROUND WATER}

Where the basalt is at, or close to, the land surface, the uplands are moderately well supplied with ground water for grazing and farmstead purposes. This supply of water comes mainly from small springs flowing form the top 200-300 feet of the basalt or from wells tapping water in those strata. Of the precipitation which falls on the plateau tops, only a small percentage gains entry to the basalt-probably less than 10 percent. The infiltration varies from place to place and apparently increases directly with the total precipitation, the granularity of a thin soil cover, the accessibility of aquifers, and other factors, such as the prevalence of snowdrifts. As described above, a gentle dip of the basalt favors the beveling of the flows and facilities this infiltration.

In places, massive parts of the basalt layers perch the water and lead it back to the surface in prominent horizons, where the springs commonly occur on the updip side of transverse declivities. Most of the upland springs are small (less than $10 \mathrm{gpm}$ ), and the outflow evaporates, again infiltrates, or in a few places heads a permanent creek that reaches the main stream. These spring branches flow generally above the level of lower ground-water bodies; hence, their courses are marked by water disappearances. Thus, in the dip-slope plateaus, basalt layers upon which water is perched function somewhat like the shingles of a roof in that they return to the surface much of the small part of the infiltration that escapes past the soil zone and allow only a still smaller part to pass to the deeper aquifers

$$
\text { INTERMEDIATE-PERCHED GROUND WATER }
$$

Beneath some plateaus, the vertical distance between the high-perched ground water and the main water table is as great as 500 feet or more. Between the two, perched ground water occurs in some basalt layers. This ground water of intermediate level generally is irregular in extent and may occupy any zone between the water that is high perched and the main water table. It 
may stand at about the level of a stream, such as Fifteenmile Creek, and many saturate several basalt flows besides the one on which the stream flows. In a highplateau, semiarid environment, where about the only recharge is by water leaking down from above, these intermediate perched zones generally lack even moderate amounts of recharge and support only weak springs of the stock-water and domestic-supply type, but they can have considerable water in storage. Locally, where it originally contributed water to a baseleveled stream, a thick saturated zone provides moderately large yields to wells; some of these aquifers yield as much as a few hundred gallons per minute to a well. Such an aquifer (possibly the stratigraphic equivalent of the "highway pillow lava" at The Dallas), about 60 feet below the top of the basalt, annually afforded the Cherry Hill (23D1), Jack Martin (14M1), Wagonblast (14L1), and a few other wells in Threemile Creek valley with several hundred acre-feet of irrigation water for about 15 years before its storage became so depleted that other water sources had to be obtained (Piper, 1932, p. 155: Stanley, 1959).

\section{LOCAL EXAMPLES OF STRUCTURAL CONTROL OF GROUND WATER}

MOSIER CREEK BASIN

Two wells (1M1 and 2J1, pl. 1) 800 feet south of the riverbank at Mosier penetrate the basalt to about a hundred feet below river level. The water they obtain is harder (172 and 209 parts per million) than is usual (50-150 ppm) for water in the basalt. This more mineralized water may rise from deep in the open-stretched joints along the axis of the Mosier syncline; it occurs with a water level equivalent to the main water table, slightly above river level. About 2 miles southeast of the Mosier wells, four irrigation wells $(7 \mathrm{E} 1, \mathrm{~B} 2, \mathrm{H} 1$, and Q1) in the basalt have water levels at altitudes near 490 feet, a little more than 400 feet higher than the water of the aforementioned wells at Mosier. Intervening between the two groups of wells is the tightly folded Rocky Prairie anticline, an uplift of about 300 feet, with a width of only a thousand feet (Newcomb, 1963). The basalt exposed in the water gap, which Mosier Creek has notched into the anticlinal ridge, includes some breccia that was formed by a grinding flexural flowage of the basalt near the axial plane (fig. 15).

The slippage of basalt strata over each other in folds has been progressively more disruptive where the radii of curvature became smaller. In tightly folded basalt, the individual joint blocks within flexed layers have been rotated with a resulting brecciation of that elongated section of the rock. This type of mechanical ac- commodation of rock to the stress was an integral part of some of the folding. It has been called flexural flowage (Donath and Parker, 1964, p. 49).

The basalt aquifers, which provide the high-standing water to these wells, should crop out in the stream canyons to the south. By stratigraphic projection (fig. 15), the points of overflow of the aquifer can be expected to occur in Mosier Creek above the forks in sec. 19 , where the altitude is about 500 feet.

In addition to the above description of the ground water in the Orchard syncline, a basinwide appraisal of ground water inflow to streams in the Mosier Creek valley was made from measurements taken at intervals along the creek in late summer.

A gaging of Mosier Creek when it consisted only of water effluent from the ground is given below, with the measured discharge listed in order ascending upstream. Numerous small springs flowing from the basalt near creek level could be observed at the time of gaging, but no large springs were seen. No spring discharge was evident from the Dalles Formation. The part of the flow provided by upland springs is from perched water in the Cascade lavas.

These measurements indicate a steady downstream gain in creek flow amounting to about 0.20 cfs (cubic feet per second) for each mile of flow over the basalt

Flow in Mosier Creek and tributaries S'eptember 12, 1962

[Measurements by William A. Hart, U.S. Geological Survey]

Cubic feet per

second Place

Mosier Creek

3.24 2.84 NW $1 / 4$ NW $1 / 4$ sec. 19 , T. 2 N., R. 12 E.

$2.40 \ldots \ldots$ In northern part of $\mathrm{SE}^{1 / 4} \mathrm{NE} 1 / 4$ sec. 1 , T. 1 N., $R$. 11 E., 0.4 mile above mouth of Honeysuckle Oreek.

90_-_._-_ Just above mouth of McVey Spring Creek, in SW $1 / 4$ sec. 14 , T. 1 N., R. $11 \mathrm{E}$.

.55_...... Below Ketchum Ranch Fork, in NW $1 / 4 \mathrm{SW} 1 / 4$ sec. 23, T. 1 N., R. 11 E.

${ }^{1} .05$

Tributaries

${ }^{1} 0.05 \ldots \ldots$ Ketchum Ranch Fork near mouth. ${ }^{2}$

135 ___ Unnamed branch, enters $1 / 2$ mile below Ketchum Ranch Fork. ${ }^{2}$

.66_-__-_ McVey Spring branch near mouth. ${ }^{2}$

.19._.... Indian Creek near mouth. ${ }^{2}$

$.42 \ldots$ West Fork near mouth ( 0.05 spring flow, ${ }^{2} 0.37$ spring flow from basalt).

\footnotetext{
${ }^{1}$ Estimated.

2 Water flows from Cascade lavas.

3 Weir.
} 


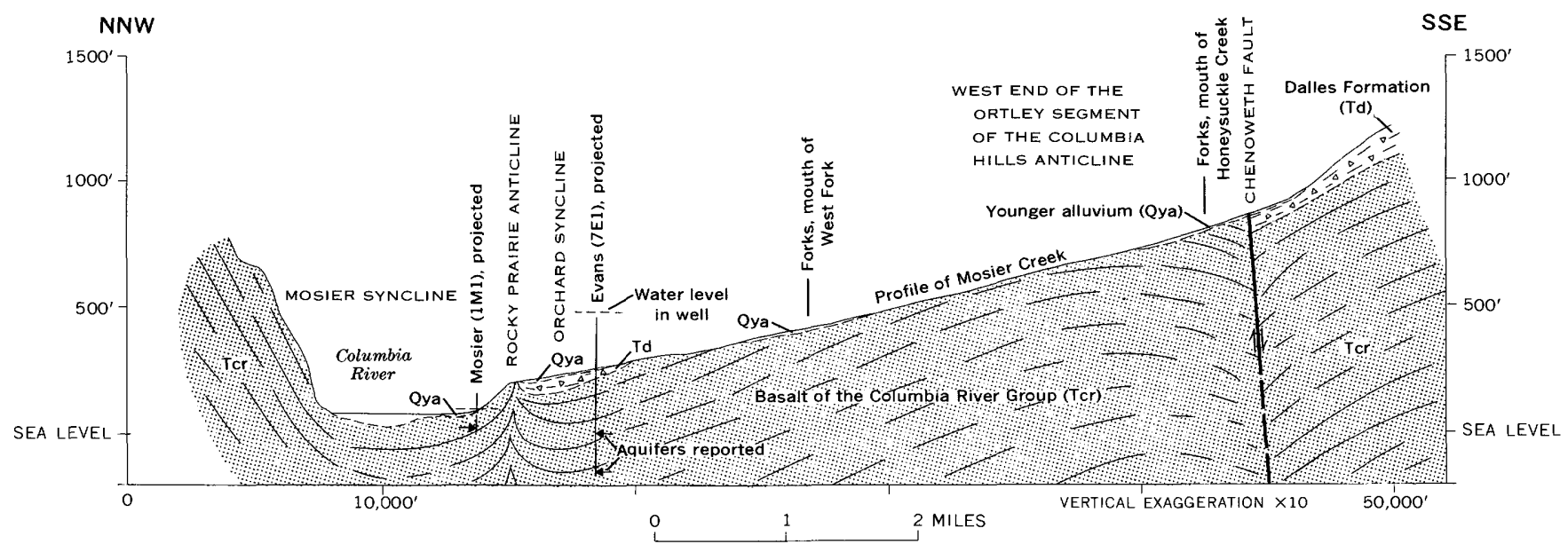

Frgore 15.-Section along Mosier Creek. (A partly idealized profile of the creek with most items projected at right angles onto a line drawn between the $S 1 / 4$ cors. of sec. $26, T .3$ N., R. 11 E., and sec. 7 , T. 1 N., R. 12 E.)

and could be interpreted as showing a gain per mile of 0.4 cfs over the Dalles Formation, plus a total inflow of 1.35 cfs issuing from ground water perched in the Cascade lavas. However, of the $1 \mathrm{cfs}$ of water not known to flow directly from the basalt or the volcanic rocks of High Cascades, the largest part $(0.84 \mathrm{cfs})$ enters the first 2 miles upstream from the south edge of the basalt and may come to the creek in the first half a mile above the mapped edge of the basalt. The south edge of the basalt, as mapped on plate 1, lies along the Chenoweth fault. Barriers in the basalt along that fault could block the northward percolation and cause the ground water to rise to the level of Mosier Creek. Just upstream from the Chenoweth fault, the basalt occurs at shallow depth beneath a cover of the Dalles Formation and bouldery alluvium. It may be assumed from the geologic relations that the ground water rises from the basalt and emerges unseen through the course alluvial debris of the creek valley. If this assumption is correct, about 53 percent of the 3.24-cfs flow was emerging from ground water in the basalt.

The indicated 3.24-cfs base flow, if prevalent as the ground-water discharge to Mosier Creek throughout the year, would indicate a natural discharge of ground water equal to about 1 inch of water per year over the 50-square-mile drainage basin of Mosier Creek. However, if we assume that the Dalles Formation allows virtually no water to pass through it to reach the ground water, 53 percent of the ground-water outflow comes from about 8 square miles of basalt and 47 percent comes from about 12 square miles of Cascade lava. These yields would be equivalent to 2.92 inches of precipitation over the area of exposed basalt and 1.68 inches over the Cascade lava area. The 2.92-inch yield for the basalt of this more humid western part is much greater than the estimated amount of recharge received by the basalt of the plateau terrain in the less humid eastern part of the area, described on page C30.

The West Fork of Mosier Creek is nourished by meager spring flow largely from perched ground water. Late in summer, the start of the creek is a small spring flowing from ground water perched in the Cascade lavas. From the edge of these lavas, the creek consists of a flow of about $0.033 \mathrm{cfs}(15 \mathrm{gpm})$ northward to the basalt. In its 2 -mile course across the basalt, the creek receives the flow of numerous small springs and increases to about $0.25 \mathrm{cfs}(110 \mathrm{gpm})$, at which rate the flow continues in the succeeding 2 miles across rocks of the Dalles Formation. In the last half mile across the basalt and alluvium, the creek is near the main water table and again gains water; it empties 0.35 to $0.45 \mathrm{cfs}$ into the main stem. The $0.22 \mathrm{cfs}$ contributed to this stream by the perched ground water from beneath a thousand acres of basalt terrain would indicate an annual yield equivalent to 1.6 inches of water per year. This area of basalt thus yields perched ground water to the stream at a unit-area rate of 55 percent of the average rate of 2.92 inches derived just above for the discharge, mostly from the main ground water, of the basaltic part of the whole Mosier Creek basin.

The springs that flow from the basalt and reach the West Fork of Mosier Creek occur at intervals along the lowest part of the valley slopes at 2,200-1,400 feet altitude. This spring discharge is from perched ground water and is returned to the surface by peculiarities of permeability along the aquifers. In contrast to the perched water flowing to the West Fork, the principal discharges from the basalt to the main stem of Mosier Creek are believed to come from ground water below the main water table. The contributions from below the 
main water table are believed to result from ground water having been impounded behind the Rocky Prairie anticline and the Chenoweth fault.

CHENOWETH CREEK BASIN

The southeast side of the Ortley segment of the Columbia Hills anticline is drained by Chenoweth Creek. Its main tributary, Brown Creek, integrates runoff from what was formerly a large segment of the Mount Hood Flat erosion surface, now partly preserved in Government and Lugan Flats.

The upland surfaces bevel at low angles the bedding planes of the tuff and tuffaceous agglomerate of the Dalles Formation. The thickly layered strata exhibit a rather phenomenal capacity to exclude water and to hold it in the thin soil zone. This surficial perching of water on the Dalles Formation has been exploited by the construction of many shallow ponds for livestock water. The basins are scraped 3-6 feet deep in upland sags and drainageways. Most ponds have water a foot or so deep throughout the summer because of the seepage that percolates laterally out of the basal part of the thin granular soil on top of the hard, massive, and durable tuff agglomerate. Several dry excavations, such as one in the SW. Cor. NW1/4 SW1/4 sec. 2, T. 1 N., R. 11 E., show that similar ponds constructed where the basalt underlies the upland surface will not store water because of the greater permeability of the weather-loosened basalt.

There are many small seeps and springs flowing from the fractured basalt and the landslid basalt along the upper part of Chenoweth Creek, but they are insufficient for a permanent creek flow. Brown Creek receives small seepages from the Quaternary lakebeds and from slidedisturbed material, but it has no through flow during the driest months of the year.

About a dozen wells are used for irrigation of the valley plains and benchlands along Chenoweth Creek between the mouths of Brown Creek and Badger Creek. The altitude of Chenoweth Creek drops from 440 to 160 feet in this 2-mile segment, and the level of the ground water descends about on the same grade, from 450 feet at the mouth of Brown Creek to 250 feet at the northernmost well half a mile south of the mouth of Badger Creek.

The drillers' records show that these wells tap water in what has been considered to be coarse-grained and permeable materials of the Dalles Formation. The wells range in depth from 130 to 450 feet and in yield from 50 to $500 \mathrm{gpm}$; they make possible the only large water withdrawal reported to be from the Dalles Formation.
One well (30N1) was reportedly drilled 3 feet into basalt (389-392 ft), at which time the water level rose from an altitude of 210 feet to 270 feet. The data on all these wells fail to demonstrate whether they draw water from the Dalles Formation or from the underlying basalt. The basalt crops out about 800 feet to the west of well 30N1 and may occur at shallow depth beneath some of these wells. If such large amounts of water were derived primarily from the Dalles Formation, these yields would be exceptional. The permeability in the Dalles Formation is known to be low in nearby wells. The lack of permeability is indicated also by the reports that the 605 -foot Walters well (30B1) obtained no water in the Dalles Formation and had to be drilled about 200 feet into basalt to obtain water. The basalt of that well yields water abundantly, but the water level stands at an altitude of only about 50-60 feet.

A part of the Chenoweth Creek basin warranting special mention is Badger Creek, which drains a synclinal subbasin along the southeast flank of the Ortley segment of the Columbia Hills anticline. The southern part of the synclinal trough is titled northeast so that it plunges to a low point near the south line of sec. 24 . The water-yielding capacity of the basalt is not adequately tested by the present domestic wells, but those wells do show that the static levels of the ground water in the basalt are near land surface in the low part of the syncline and farther below the surface in wells outside the axial area of the syncline.

MILL CREEK VALIEY

Drilling and pumping records reveal that the Mill Creek basin includes a variety of ground-water occurrences in the basalt.

Mill Creek proper and the North Fork of Mill Creek flow from the more humid environment southwest of this area. The flow of Mill Creek is independent of any discharge directly from the basalt, except for the small amount that enters the North Fork within the Mill Creek Ridge anticline.

The North Fork enters the area with an average base flow in late summer estimated at about $0.15 \mathrm{cfs}$, and receives additional water from small springs flowing from the basalt and from the alluvial or landslide materials. Its base flow in late summer increases downstream until its rate is about 0.5 cfs where the canyon starts across the beveled edges of the basalt strata in the Mill Creek Ridge anticline near the center of sec. 25, T. 1 N., R. 11 E. In this part of the canyon, the flow increases until it is about $1 \mathrm{cfs}$ where the creek leaves the basalt at the north line of sec. 31. From there downstream, 


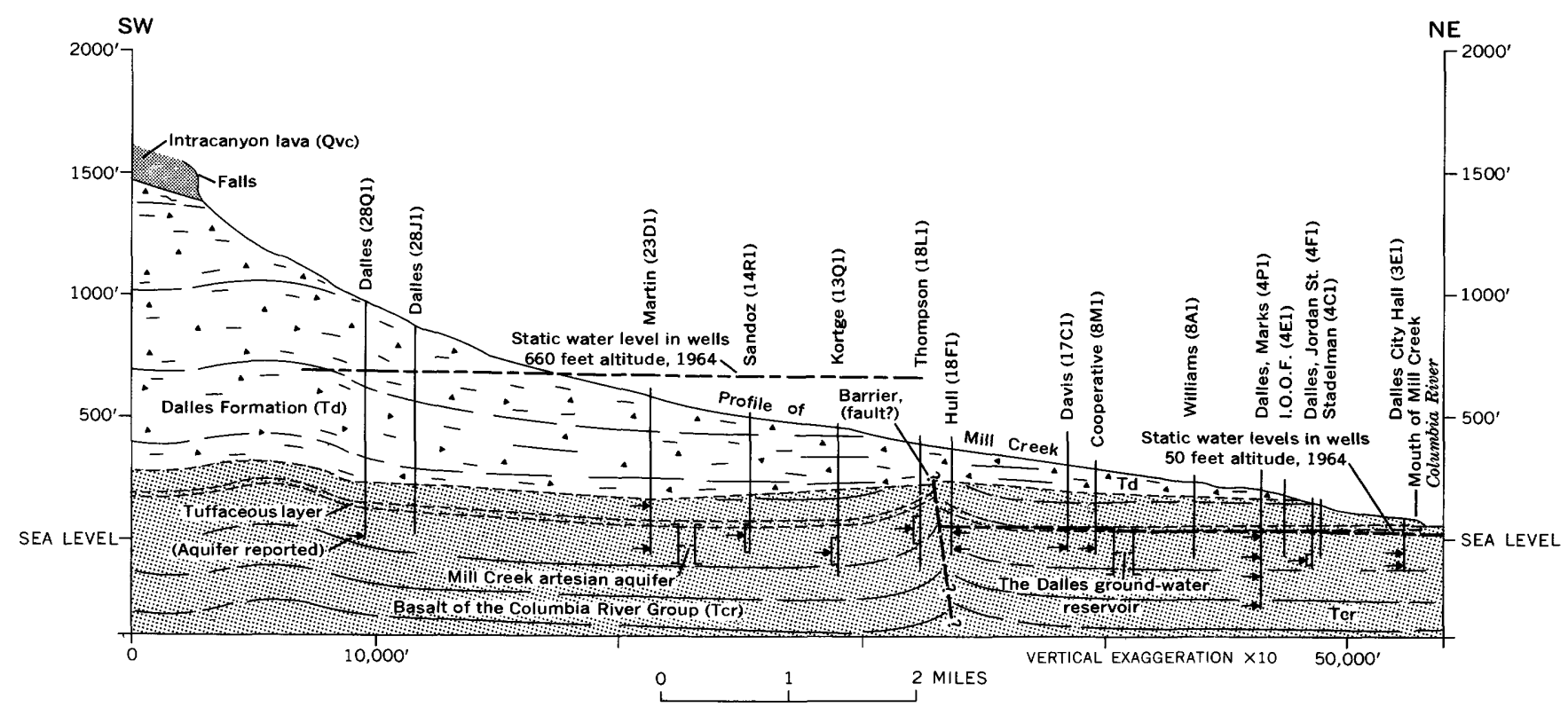

Figure 16. - Section along Mill Creek. (Profile of the creek; well information and geologic data projected at right angles to the section which trends through the Dalles City well $1 \mathrm{~N} / 12-28 \mathrm{Q} 1$ and through the mouth of the creek.)

full irrigation use and reuse is made of the creek flow. Its natural low flow remains near $1 \mathrm{cfs}$ downstream to its confluence with the main creek in sec. 22 .

The flow of Mill Creek is gaged in the SE $1 / 4$ sec. 28, about halfway between Wicks Reservoir and the south line of sec. 28 . The natural flow in late summer is only about $1.5 \mathrm{cfs}$; it is augmented by diversion of about 4 cfs from outside the basin. Downstream from Wicks Reservoir, the creek flow is altered by the diversions to the public-supply system of The Dalles, irrigation diversions and returns, spring-water inflow, leaks from the city lines, and occasional additions of water from deep wells.

As shown by the cross section (fig. 16), the highpressure artesian ground water, tapped by wells in the commonly called "Mill Creek artesian aquifer," extends south up Mill Creek valley from a barrier in sec. 18, T. 1 N., R. 13 E. at least as far as the highest well yet drilled, the city well (28Q1) above Wicks Reservoir. The five wells tapping this artesian water beneath Mill Creek valley withdrew an estimated 5,000 acre-feet of water during the period 1958-1964. The water level in the Sandoz well (14R1), a suitable index for the aquifer, declined from 188 to 172 feet above the surface during the 7 years 1957-63 (Jack E. Sceva, assistant State engineer, oral commun., 1963). The temperature of the water is $82^{\circ} \mathrm{F}$, which is $10^{\circ}$ warmer than the water in "The Dalles Ground Water Reservoir."
The completeness of the barrier at the downvalley end of this artesian zone is remarkable. As shown in figure 16 , the difference in water level across this barrier (between the Hull well, 18F1, and the Thompson well, 18L1) was originally about 600 feet. This great difference in water level occurs even though the drillers' records, the stratigraphic knowledge, and the well information (fig. 16) do not indicate great displacement, but do show a flexure of the basalt extending toward this structural barrier. The rock structure which causes this barrier has no surface expression recognized as such at this time; it has not been determined whether this fault displacement took place before or after the deposition of the overlying Dalles Formation. The possibility that it is a post-Dalles Formation fault, whose displacement is obscured in the massive agglomerate of the Dalles Formation, is not entirely excluded by the evidence at hand.

In an attempt to locate and delineate this barrier, five traverses of the ground were made in February 1966 by a commercial firm using a portable proton-type magnetometer with a reading sensitivity of 10 gammas. Three traverses northeast-southwest along the valley floor parallel to a line between the Thompson well (18L1) and the Hull well (18F1) showed a negative anomaly of 100-200 gammas occurring in a band 50-75 feet wide trending $\mathrm{N} .17^{\circ} \mathrm{W}$. through a point 100 feet west of the northwest corner of Donation Land Claim 44. A parallel traverse on the bluff along the southeast 
side of the valley obtained an anomaly of 250 gammas over a band 125 feet wide along the same trend. Either the fifth traverse, along the valley slope on the northwest side, failed to record an anomaly along this band, or the presence of the anomaly was masked by much larger negative changes produced by an orchard irrigation pipeline. Three of the magnetometer traverses also showed a positive anomaly of 100-300 gammas about 125 feet southwest of, and parallel to, the negative anomaly. The plotted lines of the magnetic reading along the five magnetic traverses are generally similar. The trend of the negative anomaly apparently represents the trace of a fault in the basalt as detected through the overlying 140 feet of Dalles Formation. The band of the negative anomaly is shown as a dashed fault on plate 1. This band alines with ravines so as to suggest a band of greater erosion in the Dalles Formation, but excavations along this trace would be necessary to identify faulting, if present in the Dalles Formation.

\section{"THE DALLES GROUND WATER RESERVOIR"}

Beneath an area of about 30 square miles centered on The Dalles, the main producing wells tap water confined in a widespread stratum of rubbly basalt breccia at about 100 feet below sea level. This highly productive aquifer was formerly called "The Dalles aquifer" or "The Dalles pool." It extends beneath the Dallesport bench on the north side of the Columbia River and the lowland northwest of The Dalles as far as Wetle Butte. It also extends east as far as the Quarry fault near the Dalles Dam, and south for about 3 miles from The Dalles. The water level in this aquifer originally stood about 77 feet above sea level, which was about 20 feet above the natural average level of the river at the port of The Dalles (Piper 1932). Subsequently (1938), the normal river-pool level at The Dalles was raised to an altitude of 72 feet by Bonneville Dam, and, in 1957, the river above the Dalles Dam was raised to 160 feet. However, the water level in this aquifer did not rise in accommodation to either change in river level. The level of the ground water has been pumped down to an altitude of about 23 feet (1964) and is declining about 5 feet per year. (See fig. 16.) In 1958, this aquifer was officially named "The Dalles Ground Water Reservoir" in a declaration of a "critical ground-water area" by the State engineer of Oregon (Stanley, 1959). Close observation of water levels and studies of artificial recharge were begun by Dalles City in cooperation with the Oregon State Engineer and the U.S. Geological Survey (Foxworthy and Bryant, 1967).
As shown in the cross section (fig. 16), the artificially depressed level of the water in "The Dalles Ground Water Reservoir" extends up.Mill Creek valley to a point between the Hull well (18F1) and the Thompson well (18L1). South of the Hull well (18F1), a fault, as described previously, impounds ground water under flowing artesian pressure. On the two sides of this structural barrier in sec. 18, there is now a difference of about 650 feet between the level of the ground water in the same water-bearing stratum.

Elsewhere, the boundaries of the area beneath which the water level is declining rapidly in "The Dalles Ground Water Reservoir" are partly known from wells. On the south, the Renken well (22B2) on Threemile Creek taps this aquifer and has water levels comparable to those of "The Dalles Ground Water Reservoir," as does the Blaser well (13N1). The Elton well (22R1), on the north limb of the Lash Ranch anticline, apparently taps ground water that has an intermediate level. When the Elton well was first drilled, an aquifer having perched water with a static level of 160 feet below the surface was developed; however, the well was later deepened to obtain greater yield and entered a more permeable layer at 719 feet. Because this deeper aquifer had water at a lower pressure level, the upper water flowed downward. The level of the composite ground waters is 600 feet below the surface, at an altitude of about 200 feet. Thus, the present information indicates that the distinctive water level of "The Dalles Ground Water Reservoir" extends south to a transition zone near the axial plane of the Lash Ranch anticline. South of this anticline, the ground water stands at higher levels, as described below.

On the east, the boundary of the "Dalles Ground Water Reservoir" seems to follow the Quarry fault, which crosses the river just below the Dalles Dam. The well (1F1) of the Threemile Irrigation Cooperative taps water in this part of the aquifer, but the motel well (1A1) and two wells (36F1 and L1) at the Dalles Dam tap water under different hydraulic conditions, mostly with water levels that conform to river levels (Jack E. Sceva, assistant state engineer, oral commun., $1965)$.

The northern limit of "The Dalles Ground Water Reservoir" seems to be the tightly folded Wetle Butte anticline. The Fred Wetle irrigation well (29G2) just south of Wetle Butte taps ground water of the "Reservoir," but the water level in the Marsh well (20H1) just north of the butte originally stood at the level of the Columbia River. The northern boundary of the "Reservoir" east of the Columbia River is poorly known, but it may continue eastward from Wetle Butte, along 
a tectonic structure, across the Dallesport bench. The Tidyman well (27B1), in which the original altitude of the water was reported to be 185 feet, is north of the boundary, but well $34 \mathrm{~L} 1$, and other wells at the airport, tap aquifers with water levels comparable to those in the "Reservoir" (fig. 17). The boundary may continue from Wetle Butte along one of the east-west faults as far as the northern continuation of the Quarry fault, as shown provisionally on plate 1 and figure 17.

There is a perplexing question as to why the ground water in the aquifer segment known as "The Dalles Ground Water Reservoir" lacks hydraulic connection with the Columbia River. The aquifer occurs along the river no lower than a hundred feet below sea level. The river has plucked (Bretz, 1924) the basalt along joints and faults to form deep trenches that extend more than a hundred feet below sea level ${ }^{1}$ in many places downstream from the Quarry fault. Thus, the present geologic information indicates that there should be hydraulic connection, but the records of water levels in the wells show that connection is lacking between the river and the ground water in this segment of the basalt aquifer. The isolation of this ground water is an important phenomenon on which data collection and study need to be continued.

Though the hydraulic isolation of "The Dalles Ground Water Reservoir" seems to restrict its recharge to the water that leaks from the higher ground water of the surrounding basalt, the aquifer constitutes a conduit-reservoir that is extensive and lies beneath an area where cheap sources of water are desired. It needs only a better recharge system. From the 30 -square-mile extent and from the apparent thickness of at least 25 feet of rubbly basalt having at least 20 percent effective porosity, the "Reservoir" is estimated to have a total capacity of about 100,000 acre-feet of water, only a small part of which has been withdrawn. Large quantities of good-quality surface water are easily at hand for artificially recharging this natural water-storage and waterdistribution facility.

\section{THE UPLANDS WEST OF THE CANYON OF THE DESCHUTES RIVER}

South of The Dalles, the Lash Ranch anticline curves across the regional northward dip of the basalt. The anticline creates an important synclinal sag on its south side. This syncline trends in a broad curve from southwest to southeast through the valleys of Threemile, Fivemile, and Eightmile Creeks. At low altitudes in this syncline, the ground water of the basalt rises in wells to about valley-plain altitudes. The ground water of

\footnotetext{
1 U.S. Army Corps of Engineers, Portland District, 1956, unpublished maps of soundings taken at and near the site for the Dalles Dam.
}

the highest principal basalt aquifer stands near the surface at an altitude of 960 feet in the Dick Brothers well (36K1) in Jap Hollow (see fig. 17), at 680 and 980 feet respectively in the Oades well $(25 \mathrm{~N} 1)$ and the Wright well (34L1) on Fivemile Creek, and at 830 feet in the Stark well (28N1) on Threemile Creek.

In five of the six flowing artesian wells in upper Threemile Creek valley, the water levels are much higher than they could be because of the barrier effects of the Lash Ranch anticline alone. Even if a complete hydraulic barrier existed along the anticlinal axis north of the Lash (32H1), Martin (32G1 and G2), Skirving (32E1), and Sanders (33M1) wells, the water would move laterally away from the area of these high pressure levels, above 1,300 feet altitude, if it were free to do so. Unless lateral barriers are present also, the high-level water would move toward Fivemile Creek 4 miles to the east, where the level of the ground water is 300 feet lower, or toward the Mill Creek artesian aquifer to the northwest, where the level is 600 feet lower. At present, the nature, position, and extent of the lateral barriers that confine the high-level artesian water of Upper Threemile Creek valley are only partly known. Records of future drilling, close geologic study, and geophysical tools may help to determine the boundaries of these important bodies of high-level ground water.

Ground water occurs in the basalt beneath the upland valleys west of the Deschutes River at three general levels: the high-perched ground water, intermediateperched ground water, and main water table.

Small springs issue at many places from the uppermost layers of the basalt. This effluence of high-perched water forms the common domestic and stock supplies of the uplands. In Standard Hollow, Douglas Hollow, and Stecker Canyon and on the top benches along the $\mathrm{Co}$ lumbia River, the discharge from the stronger springs results in late-summer creek flows as great as $50 \mathrm{gpm}$, most of which infiltrates or evaporates before reaching the perennial streams. Over much of the plateaus south and east of The Dalles, the top layer of the basalt is a pillow lava, which seems to accept infiltration readily and to allow ground-water movement downdip. Many of the domestic supplies are from wells or springs tappings this high-perched water. The wells are drilled through the Dalles Formation and obtain water in the first hundred feet or so of the basalt. The springs flow from the top of the basalt which is hidden in many places by slump from the overlying Dalles Formation.

The intermediate-perched water stands near the levels of the upland creeks and locally saturates layers about midway between the top of the basalt and the main 


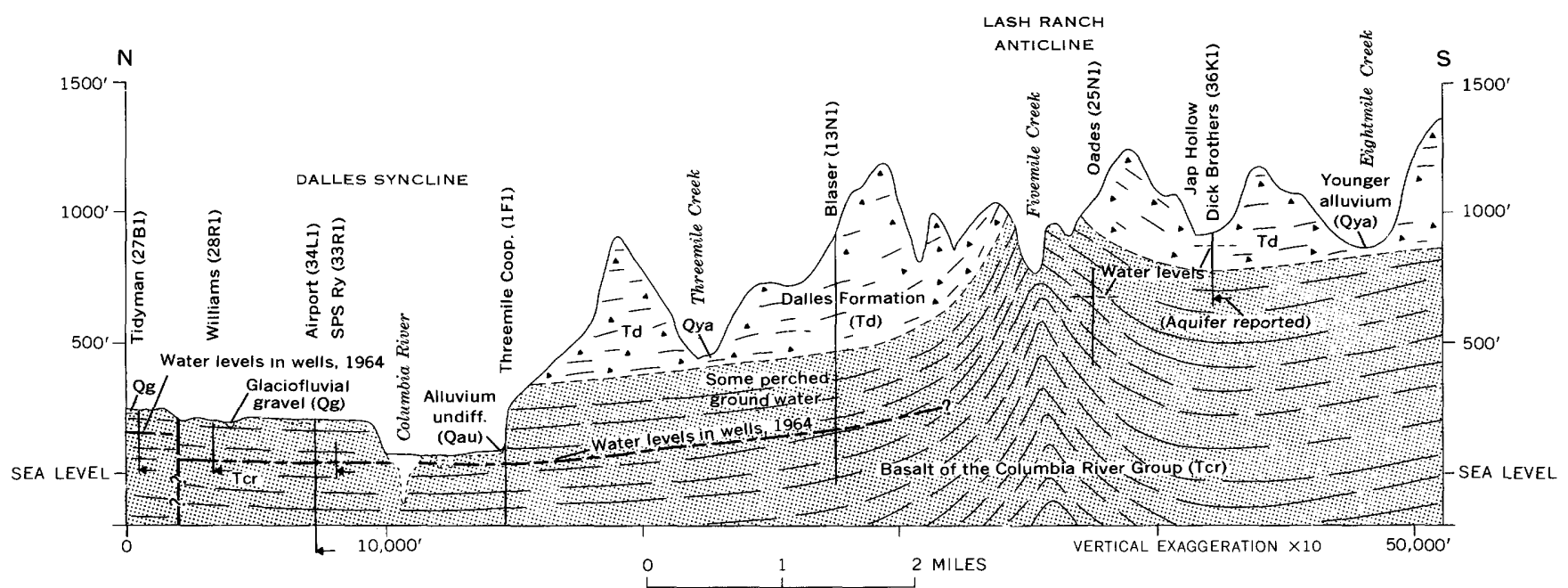

FIGURE 17.-Section north-south through The Dalles. (Hydrologic data projected to a geologic section along a line from the Tidyman well, near the N. $1 / 4$ cor. sec. 27, T. 2 N., R. 13 E., through the Dick Brothers well in Jap Hollow.)

water table. In the valley plains of the uplands, many of the domestic wells have been drilled 50-100 feet below the level of the creek and have obtained adequate water from the basalt. Most of the wells tapping zones of intermediate-perched water are pumped at rates of only a few tens of gallons per minute; the largest use of the water is for irrigation of lawns and gardens. The general similarity of the altitude of the ground water and the creeks, as well as the persistent flow of small springs to the creeks, indicates that there is some inter. play of the water in the creeks and this intermediateperched ground water. During the late summer, these creeks receive almost no runoff from the surface and only small amounts from the high-perched water; yet, despite much diversion for irrigation, water flows at intervals in Threemile, Fivemile, and Eightmile Creeks below an altitude of 400 feet, and below 600 feet in Fifteenmile Creek. Within the central or axial area of the Dalles syncline, Fifteenmile Creek has had an average natural flow of about 1 cfs during August and September of recent years, despite considerable evaporation and withdrawals for irrigation.

The thicknesses of the stratigraphic zones saturated by this intermediate-perched water are only partly known. In certain places, several aquifers may be present, and the lowest ones may lie near the level of the main water table. One of the deepest wells drawing water from one of these zones is the 300 -foot Petroff domestic well (2N/14-32H1), which has a static water level 10 feet below the surface, about equal to the level of Fifteenmile Creek nearby.

Much of the perched water trickles from outlets on hillsides and canyon walls, but that developed by wells in some of the creek valleys has levels similar to the levels of the streams. The geologic mapping shows that the streams flow across gently inclined layers of the basalt in such a way that good interchange of surface water and intermediate-perched ground water could occur locally.

Outside the area underlain by "The Dalles Ground Water Reservoir" in this plateau segment, the water below the main water table has not been tapped extensively by wells. The main water table, or its equivalent piezometric surface, occurs generally at Columbia River level in wells beneath the uplands south and southeast of The Dalles, as described on page C28. In the future, the deep ground water beneath the main water table may become important to lands in these creek valleys of intermediate altitude, such as lower Fifteenmile Creek.

\section{PLATEAU EAST OF THE DESCHUTES RIVER}

The ground-water conditions north of Gordon Ridge are much like those of the equivalent plateaus west of the canyon of the Deschutes River. The physiography of the two plateau segments also is similar, except that the larger creeks east of the Deschutes River have steeper gradients along more direct routes to the Columbia River and drain less dissected upland valleys. Beyond the first mile or so away from the river, the creek valleys are cut no more than $200-300$ feet below the plateau surfaces.

The high-perched ground water occurs in a manner similar to that described for the plateaus west of the Deschutes River and the Columbia Hills uplands. However, the outflow of water here is mostly from one zone- 
commonly about 200 feet below the top of the basaltor, in places, from an aquifer of secondary importance at the top of the basalt. Springs yielding $10-50 \mathrm{gpm}$ from this main stratum of perched ground water emerge from the southern, the updip, side of Harris Canyon. The northward flow of this perched ground water is abundantly evident in Grass Valley Creek east of this area. Ground water flows from this same zone, where it crops out in the creek valleys 2-10 miles north of Gordon Ridge. In the canyons of the northward-draining streams, the springs occur at intervals downslope from where the entrenchment first reaches the depth of the perched ground water about along the north line of T. $1 \mathrm{~N}$. The consistent stratigraphic control of the outflow from this high-perched ground water is especially striking where the water emerges near the axis of the Dalles syncline in Spanish Hollow Canyon 2 miles south of Biggs Junction (pl. 1). Fulton Canyon, followed by the east (main) branch of Fulton Creek, is floored with sufficient alluvium that the spring flows, upstream from sec. 19 , enter the stream channel inconspicuously. The spring flows entering Fulton Canyon Creek in its course north from sec. 33, T. 2 N., R. 6 E. constitute its latesummer flow of about $0.5 \mathrm{cfs}$. The west branch of Fulton Creek also receives numerous spring flows, totaling about $0.25 \mathrm{cfs}$, downstream from the uppermost spring near the high way curve in the NE. cor. sec. 31.

The late-summer inflow of all perched ground water is estimated at about $1 \mathrm{cfs}$ each to Fulton and Spanish Hollow Creeks. The only ground-water withdrawals of more than domestic- or stock-water supplies obtain enough perched water for irrigation of a few tens of acres of pasture. They are from a shallow well dug in a spring area in NE1/4 SE $1 / 4$ sec. 33 , T. 2 N., R. 16 E., and a 200 -foot drilled well in the east-central part of sec. 16, T. 1 N., R. 16 E.

Erosion along the Grass Valley syncline in Harris Canyon has brought out perched ground water and caused the creek to entrench tranverse to the regional slope. The syncline here is only the small western end of the long transverse syncline followed eastward by Grass Valley Creek.

The main water table lies deep below this platean east of the Deschutes River. As nearly as can be inferred from only a few wells along the rivers outside the plateau itself, the main water table beneath this plateau is near the level of the river.

LOCALITIES NORTH OF THE COLUMBIA RIVER

The deeply canyoned lowest part of the Klickitat River (fig. 4), the nearby rock benches along the Columbia Gorge (fig. 12), and some tributary canyons lie within the Mosier syncline. Only small amounts of perched ground water flow out into these canyons, and well-defined aquifers containing high-perched and intermediate-perched water seem to be lacking. Structural control of the ground water is displayed only by the downdip movement of water to small springs, but the topography shows that the inclination of the basalt also helped to determine the locations and shapes of the stream valleys.

Several 200- and 300-foot-deep wells at Lyle (3G1) obtain industrial and public supplies from the basalt below the main water table.

One general example of the effect of tectonic structure on the chemical quality of the ground water was evident in this part of the area. The unusual occurrence of very hard water in the Mosier wells (172 and $209 \mathrm{ppm}$, hardness as $\mathrm{CaCO}_{3}$ ) contrasts with the $50-150 \mathrm{ppm}$ commonly occurring in water from wells in the basalt and shows that the basalt in some parts of the Mosier syncline may contain ground water that is slightly more mineralized than elsewhere. Apparently this harder water rises from greater than usual depths by way of fissures caused by cracking along the axis of the syncline.

High Prairie has only meager domestic and stock supplies available from small springs that flow at, or near, the top of the basalt at the heads of canyons in this locality of flat-lying basalt. These small springs seem to be nourished by the infiltrated melt water of snowdrifts. Only a few scattered small springs drain from the 800-foot-thick section of basalt exposed in the sides of Swale Creek canyon, and this part of the creek is dry during most of the summer and fall.

The anticlinal structure of the Columbia Hills directs ground water, as well as surface water, north and south from its axial crest. Northeast from Lyle along the Columbia Hills as far as Stacker Mountain, the gentler south limb has more springs and greater effluence of high-perched ground water than the forested, more steeply dipping north limb. On the southwardsloping basalt surface near the crest of Columbia Hills, each square mile has an average of about one spring, and the flows range from 2 to $10 \mathrm{gpm}$. This discharge from the high-perched ground water is the equivalent of about a quarter of an inch of precipitation per year per square mile over the possible infiltration area of basalt terrain.

The more shattered and disjointed basalt at shallow depth and its colluvial cover beneath the north slope permit water to infiltrate and move at depth to the north. The flow of small springs from high-perched water is limited mainly to seepage areas below snowdrift sites. Most of the infiltrated water does not re- 
appear. The water that percolates deeply probably reaches the main water table and discharges directly to the river channels. Much of the infiltrated water must be caught in the deep soil zone from which it is transpired by the forest trees and by brush and other vegetation, which is more abundant on the northern side of the ridge.

South and east of Stacker Mountain, the more symmetrical structure of the Columbia Hills anticline causes about equal distribution of small springs on the two flanks.

Locally, individual structural features cause particular ground-water outflows to the Columbia Hills upland. Examples include (1) the spring flow of $30 \mathrm{gpm}$ at a change in the plunge of a shallow secondary syncline 2 miles northwest of Wishram (NW1/4 NE1/4 sec. 12, T. 2 N., R. 14 E.) and (2) the spring flow of $30 \mathrm{gpm}$ emerging above brecciated and overturned basalt at the point of the north-south anticlinal segment in NW1/4 $\mathrm{NE} 1 / 4$ sec. 9, T. 2 N., R. 14 E. The springs that flow from each side of Haystack Butte just below the southern brow of the ridge (pl. 1) seem to be a special case. Lateral dips on the top part of the basalt, possibly due to bulging upward of the basalt around the young volcanic conduit, may cause the discharge at these springs of part of the water which infiltrates to the permeable young volcanic materials making up the butte.

From the Warwick fault eastward to the Davies Pass syncline, the Columbia Hills anticline is asymmetrical, the south limb being the steeper. (See section $B-B^{\prime}, \mathrm{pl}$. 1.) The same relation of spring flows to gentler slopes, as observed farther west, occurs here; the gentle north slope has more springs discharging from the perched ground-water bodies, even though that slope is but slightly cut by ravines. The springs on the south side are limited to weak discharges high up near the rim and at intermediate levels on the rock benches.

Swale Creek valley is bounded by a 400 -foot-high anticlinal arch which trends generally east-west about a mile north of the mapped area. Between this low arch and the Columbia Hills anticline, the intervening Swale Creek syncline plunges gently west to the head of Swale Canyon, near which it ends. The Warwick fault crosses this downwarp and should form a tectonic closure of the upper part of Swale Creek valley, locally called the "Centerville Valley." The ground-water conditions in this closed part of the synclinal structure are untested, but an impoundment is believed to be present. A few shallow wells with water levels close to the surface indicate that the ground water in the top part of the basalt is held to an altitude of at least 1,560 feet at Warwick. The fault barrier may block the ground water suff- ciently that water under artesian pressure is present in the basalt to the east. (See fig. 18.)

No wells more than 110 feet deep are known to have tested the ground-water conditions in the basalt between Centerville and Warwick. Several wells southwest of Centerville obtain water in gravel(?) or rubbly basalt (?) at depths of less than a hundred feet and yield sufficient water for some irrigation. The water levels in those wells stand near an altitude of 1,580 feet. The Woods well (3N/15-21A1) yields $125 \mathrm{gpm}$ from "gravel" and has some artesian flow, though it is only 70 feet deep. An 80-foot domestic well (25C1) in the basalt at Warwick has a water level 10 feet below the surface - at an altitude of about 1,555 feet. This altitude is equivalent to that of the creek in the rock channel nearby. Water flows at the rate of about $100 \mathrm{gpm}$ from springs in the creekbed along the Warwick fault; such leakage may be a principal direct overflow at the fault zone closing this structural basin. Seepage that wets the soils to the surface is common in the lowest part of the valley above Warwick and may represent discharge of ground water.

The boundary most likely to allow lateral escape of ground water from upper Swale Creek valley appears to be the low anticline on the north. The land surface along this gentle arch is at a general altitude of 2,000 feet and approximately on the top of the basalt. In this anticlinal arch, the basalt layers are about 400 feet above the altitude of the corresponding layers along the axis of the Swale Creek syncline. For each successively deeper permeable layer, the anticlinal arch provides a correspondingly lower spillway altitude (fig. 18). Thus, hypothetically, the spill level of ground water at 400 feet depth on the anticlinal axis could balance a groundwater level equal to the top of the basalt at Warwick.

Several preliminary generalizations may be made about the geologically closed ground-water basin:

1. The ground water in the upper part of the basalt probably is perched above the main water table.

2. Static water levels may be successively lower as succeeding layers are penetrated, and the ground water below a depth of about 400 feet may have natural levels below that of the creek.

3. Any flowing artesian water will occur near, and east of, Warwick and in the upper 400 feet of the basalt, though water which rises to an altitude of 1,560 1,580 feet may occur in the basalt beneath several square miles of valley plain east of Warwick.

4. If highly permeable layers occur in the top 400 feet, the ground water beneath this part of the basin could store an annual increment of at least a few hundred acre-feet of water. 


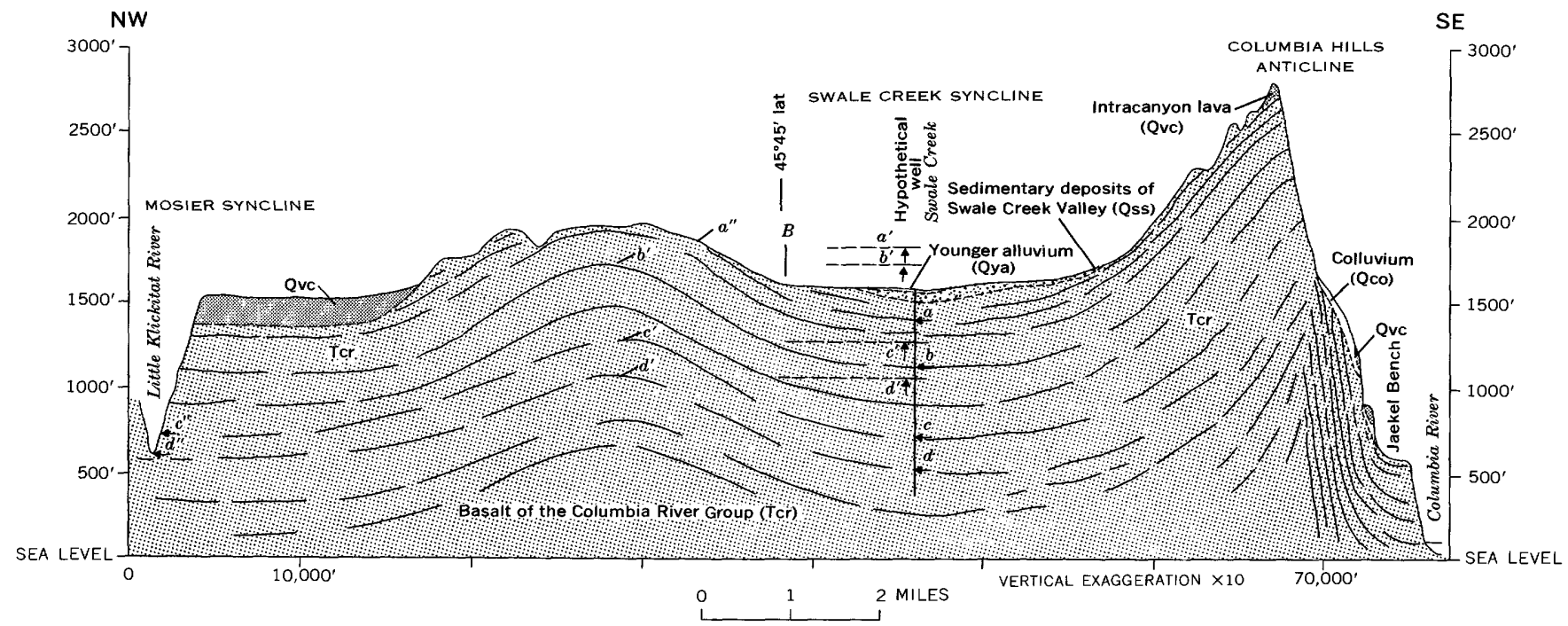

Figure 18.-Section across Swale Creek valley along the northern part, and northward extension, of section $B-B^{\prime}$ (pl, 1 ). The water levels and points of passage over the crest of the lateral anticline $\left(b^{\prime}, c^{\prime}, d^{\prime}\right)$ for the ground water confined in postulated aquifers (a, b, c, d) are indicated for a hypothetical well, and the assumed drainage points $\left(c{ }^{\prime \prime}, d^{\prime \prime}\right)$ are shown for aquifers $c$ and $d$.

5. Some of the ground water that now percolates to the canyon of the Little Klickitat River and is "wasted" might be withdrawn by future wells from this structural reservoir and be saved.

6. Presumably, future well developments will demonstrate that withdrawals of ground water from storage will make room for recharge by infiltration of surface runoff during the winter and spring months, when such a decrease in the runoff from Swale Creek basin will be beneficial.

Three miles west of Warwick, the Swale Creek valley ends abruptly where the deep Swale Canyon has been entrenched headward as far as sec. 28. Between Warwick and the canyon, stronger alluviation from the south has kept the creek pushed north of the synclinal axis, which follows the central part of the valley. Thus, near the head of Swale Canyon, the creek is cut into basalt of a prevailing southeasterly dip. The downdrop of the western side of the Warwick fault has given the basalt beneath the lower Swale Creek valley a slight dip eastward toward the fault. Ground water with levels near the surface is shown in two shallow basalt wells in the westcentral part of sec. 25 and indicates that this southeastward dip impounds some perched ground water beneath the southeast part of the valley plains in the lower part of Swale Creek valley.

\section{SUMMARY}

Tectonic deformation affects ground water chiefly in the following ways:

1. Increases the opportunity for infiltration and downward transfer of water by bringing parts of aqui- fers to, or close to, the surface and by providing steeply inclined zones of broken rock.

2. Tilts the tabular permeable layers so that advantageous gradients are available for lateral movement in the basalt.

3. Causes ground water to be impounded because of the downwarped basinal structures or because of the destruction of lateral permeability at fault zones. Some of these impoundments afford water storage at high levels beneath parts of upland plateaus, where no other significant source of water occurs naturally during the dry season.

4. Partly determines the pattern and lateral shape of stream valleys (particularly valleys that were consequent upon the terrain underlain by folded formations). It helps to determine the rates of flow in streams by directing runoff down dip slopes, diverting water to transverse drainages, raising the different rocks to where they can be entrenched by streams, and making some rocks more susceptible to erosion.

5. Alters the quality of ground water in places by increasing the opportunity for vertical circulation through rocks of different temperature or of different chemical character.

The structural study of the ground-water situations in the basalt of this area has shown a general shedding of the ground-water runoff (as well as the surface runoff) away from the anticlines and an accumulation of that ground water in the synclines (pl.1). Within this broad structural control, further structural effect on the ground water in the basalt is shown by such unusual sit- 
uations as (1) the 400-foot elevation of the water levels behind the tightly folded Rocky Prairie anticline, (2) the 600 -foot elevation of the ground water behind a fault barrier beneath Mill Creek valley, (3) the isolation of the ground water in "The Dalles Ground Water Reservoir" by several faults and folds, (4) the 800- to 1,300foot elevation of the ground water behind the gently arched Lash Ranch anticline and associated faults, and (5) the 1,500-foot elevation of ground water beneath the Swale Creek basin by enclosing anticlines and a transverse fault.

Structural controls and the corresponding groundwater phenomena are so conclusively cause-and-effect in this area, even though lack of data leaves some phenomena unexplained, that a good interpretation of geologic structure is shown to be imperative to the prediction of ground-water conditions in the basalt.

\section{REFERENCES CITED}

Allison, I. C., 1933, New version of the Spokane flood : Geol. Soc. America Bull., v. 44, p. 675-722.

Bretz, J. H., 1924, The Dalles type of river channel : Jour. Geology, v. 32, p. 139-149, 8 figs.

Buwalda, J. P., 1929, A Neocene erosion surface in central Oregon: Carnegie Inst. Washington Pub. 404, p. 1-10, 1 pl.

Buwalda, J. P., and Moore, B. N., 1930, The Dalles and Hood River Formations and the Columbia River Gorge: Carnegie Inst. Washington Pub. 404, p. 11-26, 1 fig.

Callaghan Eugene, and Buddington, A. F., 1938, Metalliferous mineral deposits of the Cascade Range in Oregon: U.S. Geol. Survey Bull. 893, 141 p., 22 pls., 7 figs.

Campbell, C. D., 1950, Petrology of the Columbia River Basalts; present status and ideas for future work: Northwest Sci., v. 24, p. 74-83.

Chaney, R. W., 1944, The Dalles flora [Oregon], chap. 11 of Chaney, R. W., ed., Pliocene fioras of California and Oregon: Carnegie Inst. Washington Pub. 553, Contr. Paleontology, p. 1-19, 353-373, illus. incl. index map.

Donath, F. A., and Parker, R. B., 1964, Folds and folding; Geol. Soc. America Bull., v. 75, p. $45-62,8$ pls., 10 figs.

Fenneman, N. M., 1931, Physiography of Western United States: New York, McGraw-Hill Book Co., 534 p., 173 figs.

Flint, R. F., 1937, Pleistocene drift border in eastern Washington: Geol. Soc. America Bull, v. 48, no. 2, p. 203-232.

Foxworthy, B. L., and Bryant, C. T., 1967, Artificial recharge through a well tapping basalt aquifers at The Dalles, Oregon: U.S. Geol. Survey Water-Supply Paper 1594-E, 55 p., $1 \mathrm{pl}, \mathrm{f}$ figs.
Hodge, E. T., 1932, Geological map of north-central Oregon: Oregon Univ. Pubs. Geology, v. 1, no. 5.

1942, Geology of north-central Oregon: Oregon State College Studies in Geology 3, 76. p., 23 figs., map.

Hogenson, G. M., 1964, Geology and ground water of the Umatilla River basin, Oregon: U.S. Geol. Survey Water-Supply Paper 1620, 162 p., 2 pls., 14 figs.

Mayers, L. R., 1964, Soil survey of Sherman County, Oregon : U.S. Dept. Agriculture and Oregon Agr. Expt. Sta., ser. 1959, no. 37, 105 p., 18 tables, 27 figs., 2 maps, 80 photog. maps.

Newcomb, R. C. 1959, Some preliminary notes on ground water in the Columbia River Basalt: Northwest Sci., v. 33, no. 1, p. 1-18.

1963, Ground water in the Orchard syncline, Wasco County, Oregon: Oregon Dept. Geology and Mineral Industries, The Ore Bin, v. 25, no. 8, p. 133-138.

- 1965, Ground water of the Walla Walla River basin, Washington-Oregon: Washington Div. Water Resources Bull. 21, 151 p., 3 pls., 15 figs.

- 1966, Lithology and eastward extension of the Dalles Formation, Oregon and Washington, in Geological Survey Research 1966 : U.S. Geol. Survey Prof. Paper 550-D, p. D59D63, 1 fig.

- 1967, The Dalles-Umatilla syncline, Oregon and Washington, in Geological Survey Research 1967 : U.S. Geol. Survey Prof. Paper 575-B, p. B88-B93, 3 figs.

Nichols, R. L., 1936, Flow units in basalt: Jour. Geology, v. 44, p. $617-630$.

Piper, A. M., 1932, Geology and ground-water resources of The Dalles region, Oregon: U.S. Geol. Survey Water-Supply Paper 659-B, p. 107-189, 9 pls., 3 figs.

Russell, I. C., 1893, A geological reconnaissance in central Washington: U.S. Geol. Survey Bull. 108, 93 p., 12 pls.

Sargent, S. C., 1956, Pl. 1 in Foundation report of the Dalles Dam, The Dalles, Oregon : U.S. Army, Corps of Engineers, Portland, Oreg., Dist.

Stanleý, Lewis A., 1959, Determination of a critical ground-water area in The Dalles area, Oregon: Adm. order of the State Engineer, Dec. 11, 1959.

Trimble, D. E., 1950, Joint controlled channeling in the Columbia River Basalt : Northwest Sci., v. 24, p. 84-88.

Walters, K. L., and Grolier, M. J., 1960, Geology and ground water resources of the Columbia Basin Project area, Washington: Washington Div. Water Resources Water Supply Bull. 8, v. 1, 518 p., 3 pls., 25 figs.

Williams, I. A., 1916, The Columbia River Gorge, its geologic history interpreted from the Columbia River Highway: Oregon Bur. Mines and Geology, v. 2, no. 3, 130 p., 77 illus. 


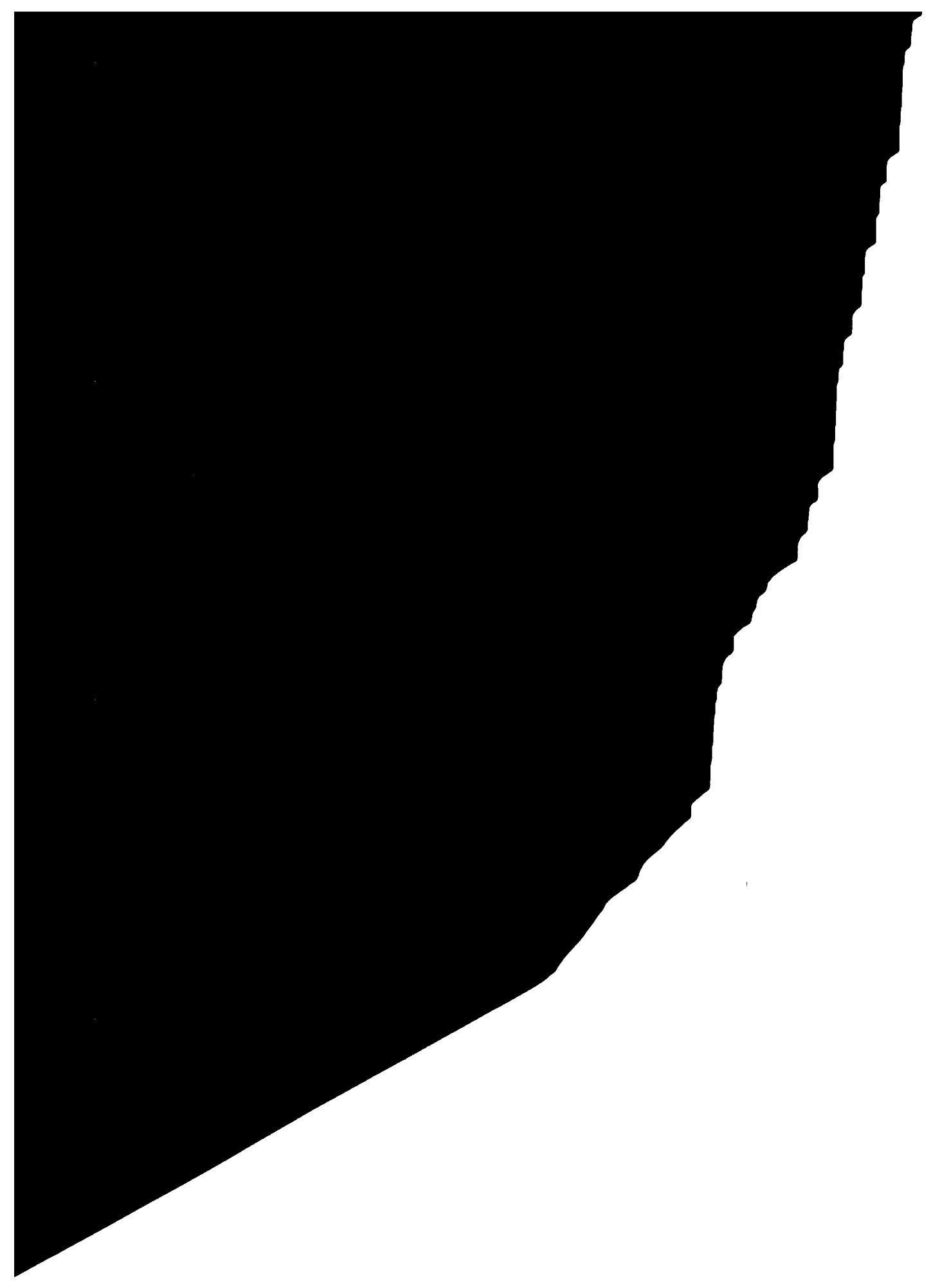

$\Delta$ 

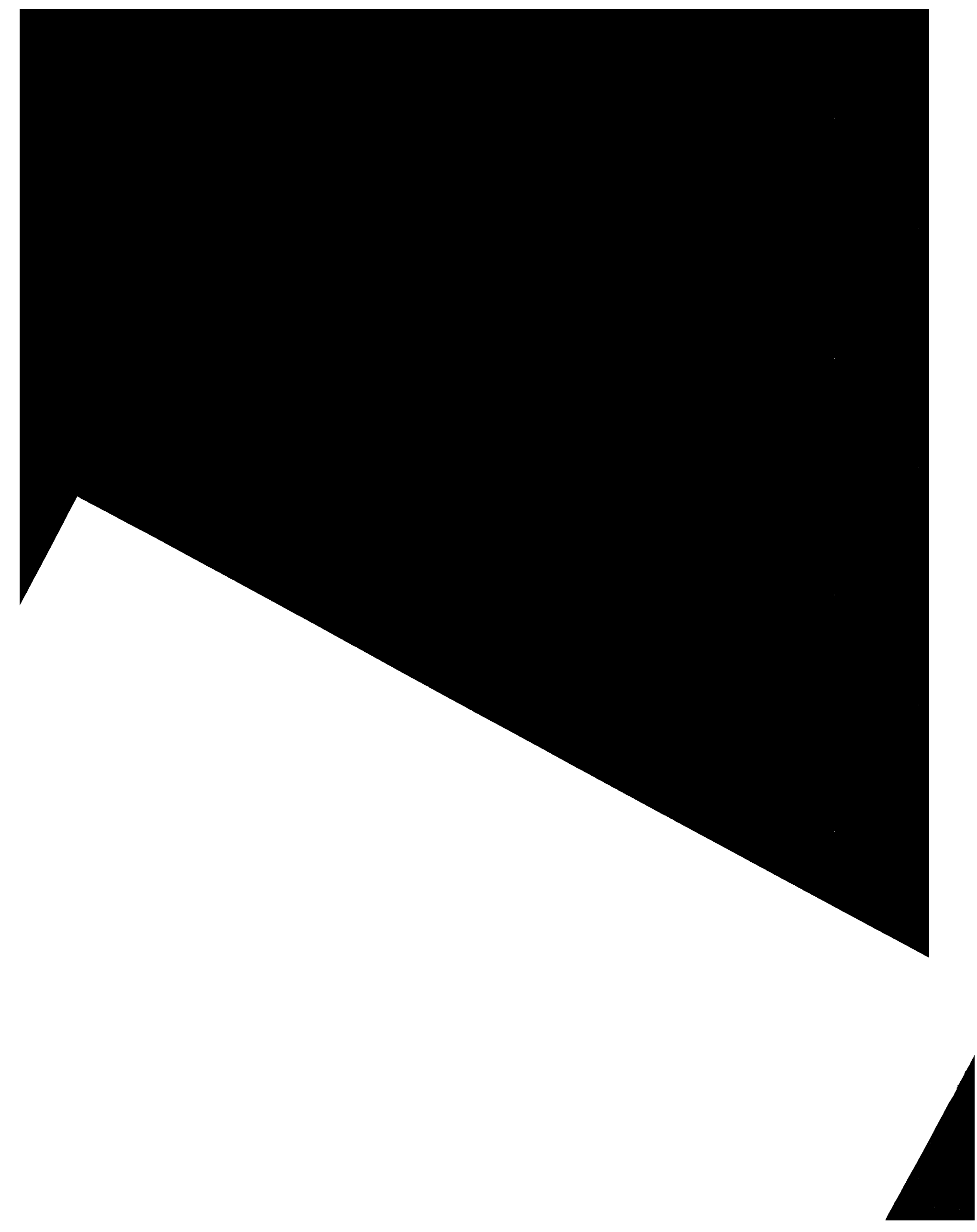